UNIVERSITY OF HELSINKI

FACULTY OF THEOLOGY

FINLAND

\title{
FREEDOM FROM PASSIONS IN AUGUSTINE
}

\section{Gao Yuan}

高 源

\section{ACADEMIC DISSERTATION}

To be publicly discussed, by due permission of the Faculty of Theology at the University of Helsinki in Lecture Hall 13, University Main Building, on 4 November 2015 , at 12 noon 
ISBN 978-951-51-1625-3 (paperback)

ISBN 978-951-51-1626-0 (PDF)

Copyright $@$ Gao Yuan (高源)

https://ethesis.helsinki.fi/en

Cover: Wang Rui and Gao Yuan

Juvenes Print Oy

Helsinki 2015 


\section{ABSTRACT}

This study presents a general overview of Augustine's insights into passions as well as his approach to the therapy of emotions and their sanctification. Attending to various phases of his writings, this work explores the systematic structure of Augustine's tenets on passions and on the freedom from passions in the context of his philosophical and theological convictions on the issue of amor sui and amor Dei.

The analysis begins by examining Augustine's language of passions and the doctrinal connections between Augustine and his predecessors. I provide a survey of Augustine's usage of emotional terms and criticise the position that Augustine suggested a dichotomy between passio and affectus as well as the claim that none of Augustine's Latin terms can be justifiably translated by the modern term "emotion". On the basis of terminological and doctrinal observations, I clarify the general features of Augustine's psychology of passions in Chapter 2. In addressing the issue of how Augustine transformed his predecessors' therapy of passions and their ideal of freedom from emotion into his theological framework in Chapter 3, I examine a series of related concepts, such as propatheia, metriopatheia, apatheia and eupatheia, to determine how he understood them in various stages of his philosophical and theological thinking. On this basis, I draw an outline of Augustine's interpretation of emotions in his theological anthropology.

During his early period, Augustine adopted the Stoic and Platonic therapy of passions and the Stoic ideal of freedom from emotion (apatheia), but he changed his position later, re-evaluating the received terminologies and values of emotions (love, will, justice, virtue, etc.) from the perspective of the doctrines of sin and grace. He developed a theological vision and evaluation of the human condition of emotions and he expressed a pessimistic attitude towards the human condition without the help of supernatural grace. Chapter 4 addresses Augustine's position on the criticism and renewal of passions in social life: the household, city, and the world.

In Chapter 5, I argue that Augustine's ideal of freedom from passions was participation in the inner Trinitarian spiritual life by the bond of the Holy Spirit as a hallmark of deification. This is wholly dependent on the divine kenosis and the transaction in the person of Christ. By virtue of the gift of grace (the salvific real presence of the Holy Spirit in faith), the pilgrimaging citizens of the City of God will be elevated to the divine realm and become transformed into a better substance in the union with God in Heaven. Contrary to arguments by some Orthodox theologians, Augustine's theory of deification is not simply a matter of fulfilment of humanity without a genuine transformation. While grace improves the control of sinful impulses in the emotional life of believers who suffer the 
consequences of the damage of the soul through original sin, Augustine maintained that the new life in Heaven denotes freedom from this emotional condition as well as the non-apathetic peaceful love and joy of resurrected persons in their participation in the divine spiritual nature. 


\section{ACKNOWLEDGEMENTS}

I would like to express my greatest thanks to my two brilliant supervisors, Professor Simo Knuuttila and Professor Miikka Ruokanen, who gave me countless invaluable directions and meticulous care during my doctoral research in Finland. I am very touched by their erudition, intelligence, genius, graciousness, and conscientiousness. I will treasure their guidance as the greatest honours in my academic life.

My sincere thanks also extend to Professor Pekka Kärkkäinen, Professor Pauli Annala, Professor Jaana Hallamaa, Professor Risto Saarinen, Professor Ismo Dunderberg and other Faculty teachers who offered generous assistance and encouragement on my work over the years. I am greatly indebted to Professor Antoine Lévy, who acted as both an "unofficial supervisor" and best friend in my daily life. My deep gratitude also goes to my wonderful Latin tutor Outi Kaltio, English reviser Kate Moore, and all my doctoral fellows at the Faculty, in which Jason Lepojärvi, Rope Kojonen, Kalle Kuusniemi, Aku Visala, Emil Anton, Heidi Zitting, Suvi Saarelainen, Taina Kalliokoski, Janne Nikkinen, Joona Salminen, and Miika Tucker who, in particular, deserve to be singled out.

In addition, I wish to extend my gratitude to my pre-examiners Professor Wu Tianyue and Dr. Timo Nisula.

I am also deeply indebted to the many other people who offered invaluable support from China and other countries: Professor Shu Ye, Professor Paulos Huang, Dr. Chen Yongtao, Mr. Donald Woods, Professor Xiao Yuanwu, among others. Furthermore, it almost goes without saying that I owe my special thanks and love to my family: my father Gao Hongpu, mother Xu Fenxia, and my younger sister Gao Rong, who unselfishly offered sustained and powerful support for my studies.

I am grateful to the organizations that have contributed to my research: Helsinki Studium Catholicum, Oxford University C. S. Lewis Society, Confucius Institute (University of Helsinki), Chinese Alppila Church, Suomen Kiinalaisten Allianssi, Education Office of the Embassy of China in Finland, among others.

Finally, I gratefully acknowledge the Chinese government and the China Scholarship Council which appointed me to pursue my $\mathrm{PhD}$ degree at the University of Helsinki and I am also proud of my great alma mater, the University of Helsinki, which provides one of the leading doctoral educational programmes in the world. I hope the cooperation between China and Finland in the field of philosophy and theology will go deeper and broader in the future.

University of Helsinki, August 2015

Gao Yuan (高源) 



\section{CONTENTS}

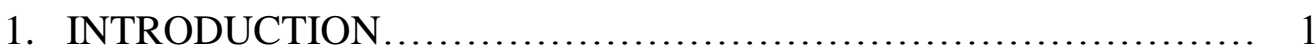

1.1. The Aim and Scope of the Study ........................................ 1

1.2. Sources........................................................................ 4

1.3. Previous Research.......................................................... 5

1.4. Chinese Studies............................................................ 11

1.5. The Outline of the Study ................................................. 12

2. AUGUSTINE'S CONCEPTION OF PASSIONS ................... 15

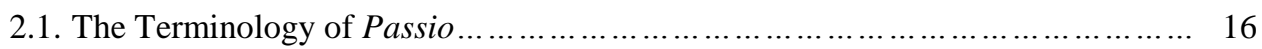

2.2. Augustine and His Predecessors on the Psychology of Passions................. 30

3. CONTROL AND MODERATION OF PASSIONS ................. 51

3.1. Disputation on Augustine's Misunderstanding of Propatheia ................. 52

3.2. Disputation on Augustine's Misunderstanding of Metriopatheia and Apatheia .. 66

3.3. The Disputation about Augustine's Misunderstanding of Eupatheia ............. 83

3.4. Augustine's Consideration of the Therapy of Passions......................... 99

3.5. The Main Lines of Augustine's Understanding of the Will and Passions.......... 112

\section{THE RENEWAL AND THE IMPROVEMENT OF PASSIONS IN} SOCIAL LIFE ........................................... 117

4.1. The Main Lines of Augustine's Social Theory........................... 118

4.2. Sexuality, Marriage and Virginity ..................................... 134

4.3. Monastery, the Church and the State ................................... 146

4.4. Libido dominandi, Just War and Earthly Peace............................. 157

5. BECOMING GOD?-REDEMPTION THROUGH PASSION AND THE DEIFICATION OF EMOTIONS ................................. 171

5.1. Augustine's Psychological Approach toward the Trinity...................... 172

5.2. Human Passions as a Confused Image of God's Metaphorical Emotions........ 183

5.3. Redemption from Earthly Emotions in the Passion of Christ................. 189

5.4. Division of Angels and Emotions as Punishments in Hell........................ 200

5.5. Becoming gods (dii) and the Fruition of God in Heaven................... 204

5.6. Evaluation of Augustine's Doctrine on the Deification of Emotions............ 213

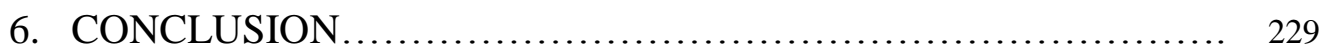

BIBLIOGRAPHY ......................................... 239

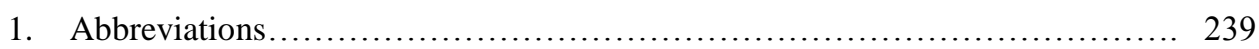

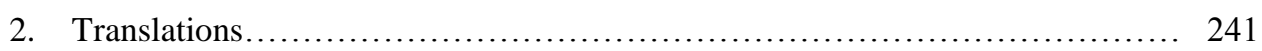

3. Studies........................................................ 244 



\section{CHAPTER ONE: INTRODUCTION}

Quare tristis es, anima, et quare conturbas me? Spera in Domino. (Psalm 42:5; Conf. 13.14.15)

Affectus sunt, amores sunt, immunditia spiritus nostri defluens inferius amore curarum et Sanctitas Tui attollens nos superius amore securitatis, ut sursum cor habeamus ad Te, ubi Spiritus Tuus superfertur super aquas, et ueniamus ad supereminentem requiem, cum pertransierit anima nostra aquas, quae sunt sine substantia. (Conf. 13.7.8)

In hoc enim loco infirmitatis et diebus malignis etiam ista sollicitudo non est inutilis, ut illa securitas, ubi pax plenissima atque certissima est, desiderio feruentiore quaeratur. (CD 19.10)

\subsection{The Aim and Scope of the Study}

Augustine was preoccupied with passions ${ }^{1}$ throughout his life, both in theory and in practice. In his Confessions, Augustine mentions that various experiences made him consider the role of passions in life, such as a theft of pears, sexual adventures with concubines, and the death of his mother, Monica. ${ }^{2}$ Through his education, Augustine was also acquainted with theoretical views on the nature of passions. For Augustine, central questions during the Platonist period after Manichaeanism and his early Christian life concerned how passions indicate sins and weakness and how he could free himself from these disturbances. ${ }^{3}$ Before his conversion in Milan, Augustine was influenced by various philosophical traditions and two of

\footnotetext{
${ }^{1}$ The term "emotion" did not appear during Augustine's time. Like his predecessors, Augustine uses a group of Latin words, such as passio, affectus, perturbatio, motus, motus animae, libido, concupiscentia, to refer to the source of behavioural changes other than free choice. I prefer to use the term "passion" in my present work when referring to emotions; the word "passion" is close to the Latin passio and the Greek pathos. However, I will occasionally also use the term "emotion" in the same meaning when it is more convenient. I will discuss the terminology of passio and its relation to the term "emotion" in Chapter Two. For a survey of the evolvement of the category of emotion, see Thomas Dixon, From Passions to Emotions: The Creation of a Secular Psychological Category (Cambridge: Cambridge University Press, 2003).

${ }^{2}$ See Augustine's Confessiones, Book II, VI and IX in particular.

${ }^{3}$ In his narrative of his early life, Augustine describes his enslavement by erotic pleasures that led him to fall victim to lusts and his suffering from the pain of loss and grief related to the death of his friend and mother. A longing for "taking flight to live in solitude" (Conf. 10.43.70: Conterritus peccatis meis et mole miseriae meae, agitaveram corde meditatusque fueram fugam in solitudinem) and freeing himself from the misery of anxieties become more intense in the latter part of Confessiones (after Book IX). For a historical study of Augustine's life, see Peter Brown, Augustine of Hippo: A Biography (Berkeley and Los Angeles: University of California Press, 2000 [First edition published in 1967]).
} 
them, Stoicism and Neoplatonism, ${ }^{4}$ became the main sources in shaping his understanding of passions as well as of how to learn a way of life without their disturbances. A range of conceptions, such as propatheia, apatheia, metriopatheia, and eupatheia, provided a general vision for considering the possibilities of emotional control. In seeking a satisfactory philosophical approach to addressing passions, Augustine was also puzzled as to how he should orient to good passions. ${ }^{5}$ After he became Bishop of Hippo, Augustine focused more on the role of grace in the therapy of desires and attempted to review that issue from a theological perspective. Especially in one of his later works, De civitate Dei, it can be seen that the motif of this magnum opus lies in freeing oneself from the passions devoted to worldly matters and moving from egoistic desires (especially pride and the passion for domination/libido dominandi) to the love of God. He summarises this history as encountering two loves, amor sui and amor Dei. ${ }^{6}$ In light of this characterisation of Augustine's long-term considerations, his conception of freedom from passions deserves careful attention and an in-depth exploration.

The main objective of this study is to provide a systematic analysis of Augustine's conception of passions as well as his approach to the salvation from their domination and the sanctification of passions. Exploring Augustine's notion of the improvement of passions as a way towards salvation involves the following series of questions: How does Augustine use the term passio?; What are the doctrinal sources for his conception of passions?; Does he follow his predecessors' example concerning the therapy of passions and their ideal of

\footnotetext{
${ }^{4}$ Augustine's early understanding of passions was closely connected to the teaching of the Platonists and Stoics, but he was neither proficient in Greek, nor familiar with philosophical works in Greek. Even though he refers to Plato, his main source for Platonism was Neoplatonist philosophy. See Brown 2000, 23-28; 79-92. For Augustine's sources, see Sarah Catherine Byers, Perception, Sensibility, and Moral Motivation in Augustine: A Stoic-Platonic Synthesis (Cambridge: Cambridge University Press, 2013); Christoph Horn, Augustinus (München: Beck, 1995); Carol Harrison, Augustine: Christian Truth and Fractured Humanity (Oxford: Oxford University Press, 2000); Harald Hagendahl, Augustine and the Latin Classics (Göteborg: Acta Universitatis Gothoburgensis, 1967).

${ }^{5}$ For instance, when facing the death of his mother, Monica, Augustine did not know how to control the overwhelming grief and he thought that his uncontrollable emotions reflected the weakness of his soul. He observes, "I closed her eyes and an overwhelming grief welled into my heart and was about to flow forth in floods of tears. But at the same time under a powerful act of mental control my eyes held back the flood and dried it up. The inward struggle put me into great agony". [Conf. 9.12.29. Transl. Chadwick]

${ }^{6}$ See Praefatio (De suscepti operis consilio et argumento) of De civitate Dei and CD 14.28.
} 
freedom from emotions?; Does he think it possible to renew and improve the passions in one's personal life and liberate oneself from the libido dominandi (lust for power) in social life to achieve terrestrial peace?; And finally, does he believe that humans can become divine by participating in the divine spiritual life of the City of God? In order to understand Augustine's insights into emotional phenomena, these questions will be studied from the perspective of various research areas such as moral psychology, political philosophy and theology, and theological anthropology along with its three dimensions: soteriology, eschatology, and the doctrine of theosis. These philosophical and theological domains form the context for explicating Augustine's conception of freedom from earthly emotions.

To obtain an overall understanding of how Augustine's conception of passions evolved, I shall focus on the works he produced during various periods of his life. Augustine's ideal of freedom from emotions was not only inspired by the philosophical sources in his early age, but were also remolded by theological considerations pertaining to his dispute with several polemists, especially the Donatists and the Pelagians, in his later years. While I shall not describe in detail the process from his early philosophical dialogues to the later theological disputes with schismatics and the heretics, I shall consider these stages in demonstrating how Augustine formulates his theological view of the nature and quality of passions. In his late polemics, a series of important theological concepts, such as love, will, justice, sin, and grace, as well as the model of Christ as God-man, are employed to re-evaluate passions and to readjust the previous philosophical paradigm of passions that had been influenced by Stoicism and Platonism. My analysis will trace this transformation of his position and explicate his systematic reflection in this context. In order to formulate a clearer picture of Augustine's notion of the redemption from emotions in the divine economy of salvation and the spiritual sanctification in the City of God, I shall examine the role of passions in the four different conditions of life separated in Augustine's theological framework: the emotional state of Paradise, the passions of this life, the sufferings of Hell, and the spiritual life of Heaven.

My general hypothesis regarding the stages of Augustine's theory of 
passions is that prior to his conversion, he is drawn to the Stoic and Platonic intellectual approach to the control and therapy of passions. The Stoic ideal of the extirpation of emotions, apatheia, and its positive counterpart, eupatheia, together with a Platonic view of the soul, all provided the primary foundation for Augustine's understanding of how to deal with the agitations of the soul as well as a model for a peace of mind. After his baptism, Augustine continues to be concerned about the power of passions and he becomes gradually aware of the limitations of human power in achieving the ideal of an apathetic life. He doubts the possibility of eradicating passions and attempts to apply the Platonic notion of control (metriopatheia) in adjusting one's emotions. At this time, he also becomes acquainted with a Christian mode of emotional therapy. In his later years, especially during his polemic with the Pelagians, Augustine becomes increasingly pessimistic about human abilities, emphasising the role of grace in the therapy of passions. His position shifts towards the theological domain of grace and predestination.

The main thesis of this study is that Augustine deviates from his earlier Stoic and Platonic paradigms related to the therapy of emotion, adopting in his late theology a soteriological view of passions in which the deification of emotions is taken to fulfil his ideal of freedom from passions and function as a hallmark of redemption. This subject has not yet been as systematically studied as it is in the present work.

\subsection{Sources}

In order to examine the formative process of Augustine's view of freedom from passions, the scope of this study's primary sources must cover his entire oeuvre. Apart from his discussions on passions, his sources for doctrinal connections with philosophical predecessors as well as his polemics against the Donatists, the Pelagians and Julian of Eclanum are naturally important here. I shall divide Augustine's writings into three time periods, adopting the years 395 and 410 as approximate dividing points. The first group consists of Augustine's early writings (before the mid-390s) such as De musica, De quantitate animae, De moribus ecclesiae Catholicae, De ordine, Contra Academicos, De beata uita, De 
immortalitate animae, and De libero arbitrio. Augustine's middle period works (written approximately 395-410) include De Genesi ad litteram, De Trinitate, Confessiones, De baptismo, Contra Faustum Manichaeum, De bono coniugali, De sancta uirginitate. The main sources from Augustine's last period (411-430) are comprised of De civitate Dei, Quaestiones in Heptateuchum, and his polemical treatises De peccatorum meritis et remissione, De natura et gratia, De nuptiis et concupiscientia, De gratia et libero arbitrio, De correptione et gratia, and Contra Iulianum, among others. In addition, his sermons, letters, and monastic Rules (Regulae) will also be taken into consideration. ${ }^{7}$

\subsection{Previous Research}

Many studies have been conducted on Augustine's understanding of passions and these represent different approaches to his theory. I shall introduce some of these studies pertaining to various areas of research, as they are useful for the purposes of this analysis.

1. Intellectual biography. This line of research highlights Augustine's individual experiences and the historical context in investigating his varying conceptions regarding sexuality and passions. Peter Brown has produced seminal works on this subject such as The Body and Society $(1988)^{8}$ and Augustine of Hippo: A Biography (2000 [1967]). In his The Body and Society (especially in chapter nineteen, Augustine: Sexuality and Society), Brown surveys the ascetic movement

\footnotetext{
${ }^{7}$ In my work, the Latin citations of Augustine and his predecessors are predominantly obtained from the CCL (Corpus Christianorum, Series Latina) and CSEL (Corpus Scriptorum Ecclesiasticorum Latinorum), which are available in the Brepolis database (for electronic version, see http://www.brepolis.net/). The old PL collection (Patrologiae cursus completes, Series Latina and the Supplementum) is also an important reference whenever a better text is not available. For Augustine's De civitate Dei, De Trinitate and Confessiones, the English translations are, if not otherwise stated, from The City of God against the Pagans, ed. and transl. R.W. Dyson (Cambridge: Cambridge University Press, 1998); The Trinity (Books 1-7), transl. Stephen McKenna, in The Fathers of the Church, vol. 45 (Washington: The Catholic University of America Press, 1963); On the Trinity (Books 8-15), transl. Stephen McKenna and ed. Gareth B. Matthews (Cambridge: Cambridge University Press, 2002); Confessions, transl. Henry Chadwick (Oxford: Oxford University Press, 1991). Furthermore, the Loeb series (Loeb Classical Library/LCL) will be used as a supplementary source. As for the English citations of the Scripture, I adopt the New King James Version (Nashville: Thomas Nelson, 1985).

${ }^{8}$ Peter Brown, The Body and Society: Men, Women, and Sexual Renunciation in Early Christianity (New York: Columbia University Press, 1988).
} 
in the Mediterranean world and portrays a panoramic picture of Augustine's experiences of sexuality and his intellectual association with various ascetic traditions. Based on a historical investigation of Augustine's early sexual adventures and confessions, Brown argues that a motif in Augustine's theology is how to free oneself from the bitter flood of sexuality in the earthly city to attain the fullness of peace in the Heavenly City. ${ }^{9}$ Brown's biographical approach to Augustine's reflection on passions is echoed by Henry Chadwick's Augustine of Hippo: A Life (2009), ${ }^{10}$ Serge Lancel's Saint Augustine (2002), ${ }^{11}$ and Robert J. O'Connell's St. Augustine's Confessions: The Odyssey of Soul (1969). ${ }^{12}$ Biographical studies on Augustine have their merits in tracing Augustine's spiritual journey and providing the historical context for his social interaction and disputes, which lay the groundwork for accessing the inner logic of Augustine's notion of passions.

2. Research on the development of theological ideas. Distinct from the biographical approach, the historical and chronological research of ideas places emphasis on the development of arguments and the doctrinal connections between separate works. These types of studies are also relevant for my own research. For example, Timo Nisula adopts this approach in his elaborate treatise on Augustine's conception of concupiscence, Augustine and the Functions of Concupiscence (2012). ${ }^{13}$ Nisula combines a chronological and systematic analysis to examine Augustine's notion of concupiscentia and traces the uses of this concept during Augustine's different periods. On this basis, he concludes that the renewal of sexual desires (concupiscentia carnis) is dependent on the efficacy of

\footnotetext{
9 " ... all had been touched by the same bitter flood of a discordant sexuality. All mankind belonged to one single city of the doomed - they were all by birth citizens of Babylon. Only by baptism and by incorporation into the Catholic Church...would human beings be enabled to join the one city of which Glorious things might be spoken: the Heavenly Jerusalem, the City of God...so faithfully mirrored in the flesh by sexuality, give way to a pax plena, to a fullness of peace". Brown 1988, 426-427.

${ }^{10}$ Henry Chadwick, Augustine of Hippo: A Life (New York: Oxford University Press, 2009). Chadwick also provides a brief survey on Augustine's ideal of continence and the ascetic tradition in the early church, see Henry Chadwick, "The Ascetic Ideal in the History of the Church", in Monks, Hermits and the Ascetic Tradition, ed., W. J. Sheils (Oxford: Basil Blackwell, 1985), 1-24.

${ }^{11}$ Serge Lancel, Saint Augustine, transl. Antonia Nevill (London: SCM, 2002).

12 Robert J. O'Connell, St. Augustine's Confessions: The Odyssey of Soul (Cambridge: Belknap Press, 1969).

${ }^{13}$ Timo Nisula, Augustine and the Functions of Concupiscence (Leiden·Boston: Brill, 2012).
} 
grace rather than human initiative. ${ }^{14}$ In her research on the role of grace in the therapy of desire, Grace and the Will according to Augustine (2012), ${ }^{15}$ Lenka Karfíková adopts a similar approach, arranging the sources according to three time periods divided by the years 395 and 410 . Through a careful interpretation of each period, Karfíková presents a process of transformation in Augustine: "nothing else do I have but will" - "the grace of God conquered" - "the will is prepared by the Lord". ${ }^{16}$ This scheme reveals the development of the concepts of grace and will. In his recent article, "Augustine's Doctrine of Deification" (2014), ${ }^{17}$ David Vincent Meconi describes the patristic tradition of the doctrine of deification and traces the deification language that is used during Augustine's different stages. Meconi has analysed Augustine's letters and sermons to show how Augustine formulated his notion of deification as well as his position on this issue.

3. Philosophical and psychological research. The notion of philosophy as psychotherapeutic and medicinal means to free the soul from emotions has had a long tradition in ancient philosophy. Many researchers have been interested in addressing the question of how this philosophical treatment of emotions was inherited and used in the Christian context (especially in the case of Augustine).

Richard Sorabji offers new insight on the transmission of the Stoic idea of freedom from emotion (apatheia) to Christianity in his book entitled Emotion and Peace of Mind (2000). ${ }^{18} \mathrm{He}$ examines various definitions of emotion in the Stoic and other Hellenistic schools and analyses how early Christian doctrines adopted the traditions of moderation and eradication. Sorabji states "the Stoic theory of how to avoid agitation was converted by early Christians into a theory of how to avoid temptation", ${ }^{19}$ but this adaption by Augustine, Sorabji observes, is based on

\footnotetext{
${ }^{14}$ Nisula 2012, 350-352.

${ }^{15}$ Lenka Karfíková, Grace and the Will according to Augustine (Leiden·Boston: Brill, 2012).

${ }^{16}$ Karfíková 2012, VII-X.

${ }^{17}$ David Vincent Meconi, S.J., "Augustine's Doctrine of Deification", in The Cambridge Companion to Augustine (second edition), ed. David Vincent Meconi and Eleonore Stump (Cambridge: Cambridge University Press, 2014a).

${ }^{18}$ Richard Sorabji, Emotion and Peace of Mind (New York: Oxford University Press, 2000).

${ }^{19}$ Sorabji 2000, 8 .
} 
misunderstandings. ${ }^{20}$ Sorabji argues that a series of misinterpretations on some Stoic conceptions, such as the first movement, apatheia and eupatheia, made Augustine blind to the Stoic ideal of freedom from emotion. ${ }^{21}$ Sorabji's interpretations have aroused controversy, which I shall address in Chapter 3.

Simo Knuuttila's Emotions in Ancient and Medieval Philosophy (2004) ${ }^{22}$ provides a detailed philosophical analysis of the psychology of passions by examining the relevant ancient and medieval theories of emotions. In discussing Augustine's view of emotions, Knuuttila argues that although Augustine adopts the Stoic classification of passions and the definition of emotions as perturbations, he does not share the Stoic view of considering the soul as an entity without an emotional part, adopting instead the Platonic tripartite theory of soul involving emotional levels. ${ }^{23}$ According to Knuuttila, this account of the soul influences Augustine's judgement that passions could not be forever eliminated in this life. ${ }^{24}$

A useful introduction to perception and sensation and the inner life of the soul is provided by Gerard O'Daly in his Augustine's Philosophy of Mind (1987). ${ }^{25}$ O'Daly offers a detailed analysis of Augustine's view of the soul and mental acts, which aids in understanding the origin and formation of passions. O'Daly also refers to the doctrine of the soul and emotions in Cicero, Platonists and the Stoics and explicates their theoretical connections with Augustine; his examination focuses on Augustine's early stage of philosophical dialogues.

As for the sources of Augustine's philosophy of passions, Marcia Colish provides a survey of his connections with philosophical traditions, especially those related to Stoicism, in her work entitled The Stoic Tradition from Antiquity to the Early Middle Ages (1985). ${ }^{26}$ Colish maintains that Augustine possesses a good knowledge of the Stoic rhetoric, psychology, ethics, physics, logic and epistemology, and she presents evidence of his being influenced by the Stoics in

\footnotetext{
${ }^{20}$ Sorabji 2000, 10-11.

${ }^{21}$ See the sections "First Movements in Augustine: Adaption and Misunderstanding" and "Christians on Moderation versus Eradication" in particular. Sorabji 2000, 372-399; 471.

${ }^{22}$ Simo Knuuttila, Emotions in Ancient and Medieval Philosophy (Oxford: Clarendon Press, 2004).

${ }^{23}$ Knuuttila 2004, 156-157.

${ }^{24}$ Knuuttila 2004, 153-155.

${ }^{25}$ Gerard O’Daly, Augustine's Philosophy of Mind (London: Duckworth, 1987).

${ }^{26}$ Marcia Colish, The Stoic Tradition from Antiquity to The Early Middle Ages (II) (Leiden: Brill, 1985).
} 
his intellectual life. ${ }^{27}$ For example, referring to the theory of passions in Stoic figures such as Zeno, Chrysippus, Epictetus and Seneca, Colish argues that Augustine adheres to the Stoic definition and classification of passions and advocates the Stoic position that virtues and correct moral judgments of passions all lie within the intellectual acts. ${ }^{28}$ Furthermore, additional related discussions of Augustine's sources and his theory of emotions are found in Perception, Sensibility, and Moral Motivation in Augustine (2013) by Sarah Catherine Byers, Martha Nussbaum's The Therapy of Desire (1994) ${ }^{29}$ as well as Upheavals of Thought $(2001)^{30}$ by Martha Nussbaum, and The Development of Ethics $(2007)^{31}$ by Terence Irwin.

In addition, I shall consider a number of articles about the psychology and therapy of passions in Augustine, such as Johannes Brachtendorf's "Cicero and Augustine on the Passions" (1997), ${ }^{32}$ Gerd Van Riel's “MENS INMOTA MOTA MANE: Neoplatonic Tendencies in Augustine's Theology of the Passions" (2004), ${ }^{33}$ Peter King's "Emotions in Medieval Thought" (2010) ${ }^{34}$ and "Dispassionate Passions" (2012), ${ }^{35}$ Sarah Byers's “Augustine and the Cognitive Cause of Stoic 'Preliminary Passions (Propatheiai)'” (2003), ${ }^{36}$ and finally, Terence Irwin's “Augustine's Criticisms of The Stoic Theory of Passions" (2003). ${ }^{37}$ Other articles consulted in the present study are articles that reflect the trend of philosophical psychology in Augustinian studies that have been compiled

\footnotetext{
${ }^{27}$ Colish 1985 (II), 142-153.

${ }^{28}$ Colish 1985 (II), 207-209.

${ }^{29}$ Martha Nussbaum, The Therapy of Desire: Theory and Practice in Hellenistic Ethics (Princeton: Princeton University Press, 1994).

30 Martha Nussbaum, Upheavals of Thought: The Intelligence of Emotions (Cambridge: Cambridge University Press, 2001).

${ }^{31}$ Terence Irwin, The Development of Ethics (Volume 1): From Socrates to the Reformation (Oxford: Oxford University Press, 2007).

32 Johannes Brachtendorf, "Cicero and Augustine on the Passions", Revue des Études Augustiniennes 43 (1997), 289-308.

${ }^{33}$ Gerd Van Riel, “MENS INMOTA MOTA MANE: Neoplatonic Tendencies in Augustine's Theory of the Passions", in Augustiniana 54 (2004), 507-531.

${ }^{34}$ Peter King, "Emotions in Medieval Thought", in The Oxford Handbook of Philosophy of Emotion, ed. Peter Goldie (Oxford: Oxford University Press, 2010), 167-188.

${ }^{35}$ Peter King, "Dispassionate Passions", in Emotion and Cognitive Life in Medieval and Early Modern Philosophy, ed. Martin Pickavé and Lisa Shapiro (Oxford: Oxford University Press, 2012a), 9-31.

36 Sarah C. Byers, "Augustine and the Cognitive Cause of Stoic 'Preliminary Passions (Propatheiai)",, in Journal of the History of Philosophy (41: 4, 2003), 433-448.

${ }^{37}$ T. H. Irwin, “Augustine's Criticisms of The Stoic Theory of Passions", in Faith and Philosophy (20: 4, 2003), 430-447.
} 
in the Sourcebook for the History of the Philosophy of Mind $(2014)^{38}$ as well as in The Cambridge Companion to Augustine (second edition, 2014). ${ }^{39}$

4. Social and political research. Augustine's insight into the passions that occur in social life has been studied by both Western and Chinese scholars. One influential work in this field is Miikka Ruokanen's Theology of Social Life in Augustine's De civitate Dei (1993). ${ }^{40}$ Ruokanen presents a systematic analysis of the doctrines of ordo, amor and civitas in Augustine's De civitate Dei. Two types of passions, superbia (pride) and libido dominandi (the lust/passion for domination), are carefully addressed in his book. ${ }^{41}$ To Ruokanen, these two desires represent a perverted order of love directed to earthly things and the ego itself and show the power of $\sin { }^{42}$ Moreover, the perversion of passion runs through human society and displays a common misery in the three circles of social life: the household or family, city and the world. ${ }^{43}$ By comparison to the future harmonious society in the City of God, Ruokanen notes that Augustine's pessimistic interpretation of this present life is based on his theocentric view that emphasises the sovereignty of the supreme good, the Creator, in both social and political life. ${ }^{44}$ Ruokanen's observations are echoed in Xia Dongqi's treatise The Earthly Authority: Social and Political Thought in Augustine (2007). ${ }^{45}$ In this doctoral dissertation, Xia follows the line of family (domus) - city (civitas) - world (orbis terrae) to analyse the concept of authority in social life and to sketch a map of Augustine's views on politics and society from the perspective of authority. Johannes Van Oort offers

\footnotetext{
${ }^{38}$ Sourcebook for the History of the Philosophy of Mind: Philosophical Psychology from Plato to Kant, ed. Simo Knuuttila and Juha Sihvola (Dordrecht: Springer, 2014).

${ }^{39}$ The Cambridge Companion to Augustine (second edition), ed. David Vincent Meconi, S.J and Eleonore Stump (Cambridge: Cambridge University Press, 2014).

${ }^{40}$ Miikka Ruokanen, Theology of Social Life in Augustine's De civitate Dei (Göttingen: Vandenhoeck \& Ruprecht, 1993).

${ }^{41}$ For the concepts of superbia and libido dominandi, see Ruokanen's analysis in section 3.4 ("The Predominance of Love in the Constitution of the Soul") and 4.4 ("Libido dominandi and the Perverse Structure of Social Power”). Ruokanen 1993, 59-69; 96-101.

42 "Lust for domination is $\sin$ and is a punishment for sin. It is a basic characteristic of civitas terrena and its perversus ordo amoris. It is not only the worst of all social vices, but the worst of all the evils in human life". Ruokanen 1993, 101.

${ }^{43}$ Ruokanen 1993, 108-111.

44 "According to Augustine, God the Creator is not absent from any level or form of social life. He is always present as the good Creator of natura bona and as the just Judge of those who distorted the beautiful and harmonious order of the nature he created. Augustine's thinking is thoroughly theocentric". Ruokanen 1993, 159.

${ }^{45}$ For Xia's work, see footnote 52 below.
} 
new insight into Augustine's concept of the two cities in his work entitled Jerusalem and Babylon (1991), ${ }^{46}$ focusing more on the sources and background of Augustine's doctrine of the two cities. Apart from these monographs, some articles are also important in addressing Augustine's view of moral virtues and social theory, such as John Parrish's “Two Cities and Two Loves: Imitation in Augustine's Moral Psychology and Political Theory” (2005) ${ }^{47}$ and Paul Weithman's “Augustine's Political Philosophy” (2001). ${ }^{48}$

\subsection{Chinese Studies}

I would like to add that Augustinian research has currently gained a footing in China. Although the main secondary sources for my present work consist of Western studies, I would also like to briefly introduce the basic Chinese studies that have been conducted on Augustine. The earliest Chinese scholarly work on Augustine was written by J. Wang Tch'ang-Tche (王昌祉) who analysed Augustine's conception of virtues in his French-language dissertation "Saint Augustin et les vertus des païens" 49 in the 1930s. During this period, a translated biographical introduction to Augustine also appeared. ${ }^{50}$ However, these works did not generally attract attention from contemporary intellectuals, and there were no scholars in Augustinian studies during the subsequent half a century in Mainland China. However, a number of scholars became interested in the last decade of the twentieth century, producing introductions to Augustine, translations of his principal writings, and commentaries on his work. ${ }^{51}$ Some important Chinese

\footnotetext{
${ }^{46}$ Johannes Van Oort, Jerusalem and Babylon: A Study into Augustine's City of God and the Sources of His Doctrine of the Two Cities (Leiden: Brill, 1991).

${ }^{47}$ John M. Parrish, "Two Cities and Two Loves: Imitation in Augustine's Moral Psychology and Political Theology", in History of Political Thought, 26 (2005), 209-235.

48 Paul Weithman, "Augustine's Political Philosophy", in The Cambridge Companion to Augustine, ed. Eleonore Stump and Norman Kretzmann (Cambridge: Cambridge University Press, 2001), 234-252.

49 J. Wang Tch'ang-Tche (王昌祉), Saint Augustin et les vertus des païens (Paris: Gabriel Beauchesne, 1938).

50 吳維亞(譯述): 《聖奧古斯丁》(基督教學術推進會叢書: 小傳集二), 上海: 廣學會, 1937/A. Shirley: Augustine, Saint Bishop of Hippo, translated into Chinese by Wu Weiya (Shanghai: Guang Xue Hui, 1937).

${ }^{51}$ The main Chinese translation involves Augustine's Confessiones, De Trinitate and De civitate Dei as well as De cathechizandis rudibus, De doctrina Christiana, De gratia et libero arbitrio, De natura et gratia, De anima et eius origine, etc. For the translation and the relevant Augustinian
} 
monographs include 《神圣的呼唤: 奥古斯丁宗教人类学研究》《记忆与光 照：奥古斯丁神哲学研究》 《奥古斯丁的基督教思想》《意愿与自由: 奥古 斯丁意愿概念的道德心理学解读》 《尘世的权威：奥古斯丁的社会政治思 想》 ${ }^{52}$ In addition, some Chinese journals have launched columns and channels dedicated particularly to Augustinian discussions, such as 《现代哲学》(Modern Philosophy), 《基督教思想评论》(Recent Review of Christian Thoughts) and 《西学研究》(Studies on Hellenic and Western Civilization). ${ }^{53}$ These studies and publications provide a perspective to the patristic studies in a Chinese context and attempt to establish a dialogue between Augustinian theology and Chinese traditional religions. This approach displays originality and value in comparative religious studies. Considering the focus of this study, I will not address Augustine's theology in the context of these comparative Chinese studies, but I shall nevertheless occasionally refer to them as I examine Augustine's conception of passions.

\subsection{The Outline of the Study}

This study begins with an analysis of Augustine's language of passions. In Chapter 2, I shall provide an overview of Augustine's conception of passions by examining his use of the term passio and related terms. Based on the lexical observations, I shall move to an analysis of the historical background of his theory of passions and investigate which doctrinal traditions influence his conceptions

articles in Chinese, see Zhou Weichi, Augustine's Christian Thought (Beijing: China Social Sciences Press, 2005), 371-380.

52 张荣: 《神圣的呼唤: 奥古斯丁宗教人类学研究》, 石家庄: 河北教育出版社, 1999/Zhang Rong, The Holy Call: A Study on Augustine's Theological Anthropology (Shi Jia Zhuang: He Bei Education Press, 1999); 周伟驰: 《记忆与光照: 奥古斯丁神哲学研究》, 北京: 社会科学文献出 版社, 2001/Zhou Weichi, Memory and Light: A Study on Augustine's Theology (Beijing: Social Sciences Academic Press, 2001); 周伟驰: 《奥古斯丁的基督教思想》, 北京: 中国社会科学出 版社, 2005/Zhou Weichi, Augustine's Christian Thought (Beijing: China Social Sciences Press, 2005); 吴天岳: 《意愿与自由: 奥古斯丁意愿概念的道德心理学解读》, 北京: 北京大学出版 社, 2010/Wu Tianyue, Will and Freedom: A Moral Psychological Interpretation on Augustine's Concept of Voluntas (Beijing: Beijing University Press, 2010); 夏洞奇: 《尘世的权威: 奥古斯丁 的社会政治思想》, 上海: 三联出版社, 2007/Xia Dongqi, The Earthly Authority: Social and Political Thought in Augustine (Shanghai: San Lian Press, 2007). These works are written in Chinese and the English titles added here are mine.

${ }^{53}$ See Xia Dongqi 2007, 21 and n. 7. 
and to what extent he follows the predecessors' teachings of the psychology of passions. I am also concerned with the questions of whether this usage is interchangeable with how the modern term "emotion" is used and whether this is an adequate translation for Augustine's passions terminology.

After analysing the semantics of passions and the doctrinal sources, I shall proceed to the therapy of passions and examine whether Augustine adopts the Stoic and the Platonic ideal of freedom from emotions. A series of conceptions pertinent to the control of emotions (propatheia, metriopatheia, apatheia, and eupatheia) will be studied to determine how Augustine formulated his position. An analysis of the argumentation associated with these concepts in his various stages is particularly importance in understanding his final attitude toward the philosophical ideal of freedom from emotions. Following an analysis of Augustine's statements in different periods, I shall offer an outline of his position on emotions in his late theology. On this basis, in Chapters 4 and 5, I shall move on to discuss Augustine's approach to the improvement of earthly passions and his position on the final spiritual status of the passionate soul in the Kingdom of God by virtue of divine salvation.

Chapter 4 presents Augustine's position on the renewal of passions in social life, which is divided into the three circles of human life: household, city, and the world. The background of Augustine's theory of the two cities will be addressed through analysing his theological anthropology in terms of the origin of passions and the root of depravity. To explicate Augustine's theological principle of the alignment of values of emotions and his approach to the renewal and improvement of passions in the world of temptations, I shall examine Augustine's view on the three levels of passions in earthly life: concupiscence, pride, and libido dominandi.

Chapter 5 explores the final orientation to the freedom from passions proposed by Augustine. I shall first discuss Augustine's psychological Trinitarian metaphors and divine "emotions" that clarify his view of the inner spiritual life in the Trinity. Augustine argues that by the gift of grace, the pilgrimaging citizens of City of God will be elevated to participate in the Trinitarian life in Heaven. This involves a real deificatory transformation that is based on the redemption in the 
person of Christ. I shall explore Christ's emotions and Augustine's view of the salvific transaction in which Christ takes on human emotions and offers deification to humans. I shall demonstrate that Augustine's theological theory of eschatological theosis is not simply a matter of fulfilment of humanity without a genuine transformation. While grace improves the control of sinful impulses in the emotional life of believers who suffer the consequences of the damage of the soul through original sin, Augustine maintained that the new life in Heaven denotes freedom from this emotional condition as well as the non-apathetic peaceful love and joy of resurrected persons in their participation in the divine reality.

Chapter 6 will offer a summary of this study. 


\title{
CHAPTER TWO: AUGUSTINE'S CONCEPTION OF PASSIONS
}

\author{
Quod, propinquante passione, tristis fuerit anima eius, non falso utique referuntur. \\ (CD 14.9)
}

Sed cum rectam rationem sequantur istae affectiones quando ubi oportet adhibentur, quis eas tunc morbos seu vitiosas passiones audeat dicere? (CD 14.9)

Non tamen semper his proprietatibus locutio nostra frenanda est, sed interdum his utendum est. (CD 14.8)

This chapter will address the question of how Augustine uses and understands the term passio and will further compare Augustine's terminology and his predecessors' terminology as well as their doctrines of passions. The first section presents an analysis of the usage and characteristics of the term passio as well as those of the other closely related terms used by Augustine, such as affectus, motus and perturbatio. In addition, I shall discuss the proposal by some scholars that Augustine tends to classify emotional terms into two groups: passio, which is negative, and affectio (affectus), which is positive. Furthermore, I shall explore whether these Latin words in Augustine's usage could be translated by the term "emotion" as it is the current practise. In the second section, to evaluate the doctrinal relationship between Augustine and his predecessors, I shall present a general outline of the terminology and psychology of passions in both Stoicism and Platonism, inquiring whether Augustine is more inclined to the Neoplatonic theory of passions or the Stoic theory. This section is largely based on recent investigations of Augustine's philosophical and theological sources. By focusing on the interrelated questions posed in these two sections, I shall provide general remarks on the term passio in Augustine's works as well as an outline of Augustine's conception of passions. It will be argued that Augustine adopts neither the Stoic characterisation of passions as diseases (morbi), nor the Platonic-Peripatetic ${ }^{1}$ ideal

\footnotetext{
${ }^{1}$ Augustine did not distinguish between the Platonic and Aristotelian positions on the psychology of passions as strictly as we tend to do today. When he mentions either the "Platonic" or "Peripatetic" notion of passions, Augustine refers to their coinciding views as an eclectic alternative to Stoicism. As he explains in CD 9.4: Duae sunt sententiae philosophorum de his animi motibus, quae Graeci $\pi \alpha \dot{\theta} \eta$...Has ergo perturbationes sive affectiones sive passiones quidam philosophi dicunt etiam in sapientem cadere, sed moderatas rationique subiectas, ut eis leges quodam modo, quibus ad necessarium redigantur modum, dominatio mentis inponat. Hoc qui sentiunt, Platonici sunt sive Aristotelici, cum Aristoteles discipulus Platonis fuerit, qui sectam Peripateticam condidit. Aliis autem, sicut Stoicis, cadere ullas omnino huiusce modi passiones in sapientem non placet. In my work, I accordingly do not differentiate between the terms "Platonic", "Neoplatonic" and 
of unaffected heroes, but rather uses the terminology of passio in a flexible way, emphasizing the value of passions in a virtuous life and constructing his own theory of passions within a Christian semantic context. These results will serve as the basis for further discussion on the issues of moderating and controlling passions in the next chapter.

\subsection{The Terminology of Passio}

Some scholars claim that Augustine tends to classify emotions into two groups on the basis of whether he regards them as good or bad. I shall evaluate this argument and examine whether there is any textual support for this in Augustine.

Thomas Dixon and Anastasia Scrutton maintain that most Latin words for "emotions" in Augustine's work need to be classified into two groups, passio and affectio, with passio attributed a negative connotation and affectio a positive connotation. $^{2}$ Dixon argues in From Passions to Emotions, that Augustine does not adopt the Stoic apathetic idea of excluding both affectiones and passiones, but instead expresses a positive attitude towards affectiones (which are obedient to reason), differentiating these voluntary affections from unruly passions that occur in a virtuous and healthy life. ${ }^{3}$ The distinction between affectio and passio, Dixon explains, is based on Augustine adopting the Peripatetic bipartite theory of the soul comprising a higher, intellective level as well as a lower, appetitive level. ${ }^{4}$ Dixon states the following: "For Augustine the most troubling passions, lusts, desires and appetites were involuntary movements of the lower parts of the soul, rather than voluntary judgments". ${ }^{5}$ Consequently, affectio and passio (as well as other related terms) refer to two diametrical groups in Augustine: passio, perturbatio and libido

"Peripatetic" when referring to Augustine's "(Neo)Platonic-Peripatetic position".

2 See Dixon 2003, 26-61; Thomas Dixon, "Revolting Passions", in Modern Theology (27:2, 2011), 299-302 (This article is also collected in Faith, Rationality and the Passions, ed. Sarah Coakley (Wiley-Blackwell, 2012), 181-195); Anastasia Scrutton, "Emotion in Augustine of Hippo and Thomas Aquinas: A Way Forward for the Im/passibility Debate?", in International Journal of Systematic Theology (7:2, 2005), 169-177.

3 "Augustine poured scorn on the Stoic aspiration to attain apatheia, or complete impassivity, in this life... This forceful rejection of Stoic impassivity should be sufficient to illustrate that Augustine did not wish to exclude passions and affections altogether. It is worth noting, however, that the term he used here for proper affect is affectus rather than passiones. However, this provisionally positive stance on the necessity of human affections in this life was combined with a more negative attitude to the passions in Augustine's other works". Dixon 2003, 40-41.

${ }^{4}$ Dixon 2003, 46.

5 Dixon 2003, 50-51. 
are the movements of the lower part of the soul, whereas affectio, affectus and motus are related to the intellective part. ${ }^{6}$ Dixon also notes that the affection/passion distinction is closely connected to the distinction between virtue and vice, with virtuous movements being cultivated by reason and will. ${ }^{7}$ This twofold moral axiom regarding affections and passions, Dixon explains, became a standard view in moral philosophy, lasting until the nineteenth century. ${ }^{8}$ Anastasia Scrutton also states that "there is a tendency in Augustine's work to use passiones (and related words such as perturbationes, libido and morbos) in a pejorative sense, and to contrast these with virtuous affectus, motus and affectiones". ${ }^{9}$ In line with Dixon, Scrutton explains that passions refer to the improper movements of the appetitive part of the soul, while affections are proper acts guided by the reason, will, and love of the higher intellective self. ${ }^{10}$

Based on the above-mentioned distinction between affectio and passio as positive and negative phenomena, one could argue that there are no psychological Latin terms that would be equivalent to the modern term "emotion". ${ }^{11}$ Indeed, Scrutton and Dixon maintain that pathē, passio and affectio cannot be regarded as "emotions" in the contemporary sense of the word. This is partly due to the aforementioned Greek and Latin terms having their own connotations as well as partly because the term "emotion" did not emerge in the English language until the

\footnotetext{
${ }^{6}$ See the classification of emotional terms in Dixon 2003, 48. This classification is repeated in his article "Revolting Passions" in which he explains that "Augustine was suspicious of those movements of the appetite that he considered misdirected passiones, perturbationes, libidines or even, in Stoic vein, morbos; but he took a more positive stance towards higher movements of the will given milder designations such as motus, affectus, affectiones or simply voluntates, acts of will". Dixon 2011, 300; Dixon 2012, 183.

7 "To live according to one's highest nature was to live as a rational animal, with libidinous passions subdued and godly and sympathetic affections cultivated (by reason, by the will, by habit). This twofold moral axiom - subdue passion, cultivate affection - assumed a division between reason and the passions. A governed and rational passion, properly educated and smartly dressed, could be deemed to have won the approval of the will and intellect, and to have gained entry into polite society in the form of sympathy, affection and sentiment". Dixon 2012, 185.

${ }^{8}$ Dixon 2011, 301-302; Dixon 2012, 184-185.

9 Scrutton 2005, 170.

10 "In practice it is often the case that passions are sinful, because (as a consequence of the fall) the lower sensitive self is in rebellion against the higher intellective self, which should be its master and guiding principle. Whether a particular passion or affection is virtuous or vicious is dependent upon two factors: first, the agreement of the emotion with reason, and, second, the object of the emotion, which is closely related both to the direction of the will and to the orientation of the subject's love...these two conditions which determine the moral status of an 'emotion' also incline passions to be sinful, and allow affections to be virtuous". Scrutton 2005, 172.

11 "Statements by pre-modern theologians and their early-modern successors about either the terrible tyranny of the passions or the value of moral sentiments and religious affections cannot be taken as evidence of any generalized attitude to the "emotions"'. Dixon 2011, 302; Dixon 2012, 185.
} 
seventeenth century, acquiring its modern meaning only in the nineteenth century. ${ }^{12}$ For example, the term "emotion" did not appear in the English translations of the Bible produced before the nineteenth century. ${ }^{13}$ Dixon points out that the transition from the category of "passions" to the modern term "emotion" can be attributed to some neuroscientists and psychologists - Thomas Brown, Thomas Chalmers, Alexander Bain, Herbert Spencer, and Charles Darwin - who adopted "emotion" as a scientific cachet to replace the former multifarious terminology. ${ }^{14}$

However, some scholars dissent from this distinction. For example, Johannes Brachtendorf notes that "Augustine treats the terms, perturbationes, affectiones, affectus and passiones as equivalent". ${ }^{15}$ Brachtendorf supposes that this equivalence between different terms is based on Augustine's deliberate aim to refute the Stoics and that Augustine uses these terms flexibly in his City of God. ${ }^{16}$ In discussing ancient views of emotions, Martha Nussbaum does not differentiate between "emotion" and "passion". She follows this approach not only when discussing the Stoics, but also when discussing Augustine:

I shall use these two words more or less interchangeably, making no salient distinction between them. 'Emotion' is the more common modern generic term, while 'passion' is both etymologically closer to the most common Greek and Latin terms and more firmly entrenched in the Western philosophical tradition. ${ }^{17}$

Like Nussbaum, Simo Knuuttila is also inclined to support the position that Augustine does maintain a strict distinction between these emotional terms: "Augustine sometimes calls emotions perturbations, as Cicero did, but he uses

\footnotetext{
12 Scrutton 2005, 170; Dixon 2003, 1-26.

13 “'Emotions', unlike 'affections', 'passions', 'desires' and 'lusts' did not appear in any English translation of the Bible... One word that was not used in the classical Christian account of passions and affections was 'emotions'. There was no such term in classical Latin or Greek, nor in the Bible (nor, incidentally, do the words 'emotion' or 'emotions' appear in any of the major English translations of the Bible)". Dixon 2003, 4 and 39.

${ }^{14}$ See Dixon 2012, 186-187; Dixon 2003, 13-19. Dixon argues that with the employment of the word "emotion", "previous distinctions between appetites, passions, affections and sentiments were gradually forgotten. Members of all these older categories could now be found masquerading as emotions". Ibid., 187. Dixon credits this view to James Mark Baldwin and G. F. Stout by quoting their account of "emotion" in Dictionary of Philosophy and Psychology: "The use of the word emotion in English psychology is comparatively modern. It is found in Hume, but even he speaks generally rather of passions or affections. When the word emotion did become current its application was very wide, covering all possible varieties of feeling, except those that are purely sensational in their origin". See Dixon 2003, 1 and 17.

${ }^{15}$ Brachtendorf 1997, 299.

${ }^{16}$ Brachtendorf states that "Augustine is not interested in a positive evaluation of the passions", adding that "although Augustine was well aware of these [terminological] differences, he deliberately omits them in his City of God". See Brachtendorf 1997, 299-300.

${ }^{17}$ Nussbaum 1994, 319 (n. 4).
} 
more neutral terms, such as affections (affectiones), affects (affectus), or passions (passiones)". ${ }^{18}$ Furthermore, Gerard O'Daly emphasises that Augustine "adduces a series of scriptural and secular texts (the latter from Terence, Cicero and Virgil) to show that linguistic usage does not distinguish between good and bad when describing emotions". ${ }^{19}$ Timo Nisula agrees with O’Daly: “Augustine's terminology of emotions is flexible. Terms occur such as adfectus, passiones, perturbationes, or even libidines in the general sense of "emotion"". ${ }^{20}$ Richard Sorabji likewise states that he prefers to use the term "emotion" to express all the Hellenistic and early Christian usages of emotional terms in his book Emotion and Peace of Mind. ${ }^{21}$ It could also be mentioned that some translators of Book 9 in City of God, such as David Wiesen, Gerald Walsh and Grace Monahan, prefer to adopt a flexible approach by translating Augustine's use of passio, affectus and motus as "emotion". 22

With respect to these different perspectives on passio and affectus, it is evident that the main question concerns our understanding of the term passio. Those who maintain a dichotomic position predominantly posit passio (or perturbatio) as a movement of the lower part of the soul, or as a perturbation of the mind, often involving a strong impulse, such as appetite and sexual or evil desire. For this reason, they translate passio as "passion". Affectus, on the other hand, is a movement of the higher part of the soul or a virtuous feeling in accordance with a person's will and intellect, and scholars who posit a dichotomy translate it as "affection". Thus, none of these terms could be regarded as equivalent to the modern term "emotion". On the contrary, those who dissent from this distinction assert that passio cannot be confined to the same limited scope of meaning as the

\footnotetext{
${ }^{18}$ Knuuttila 2004, 156.

${ }^{19}$ Gerard O'Daly, Augustine's City of God: A Reader's Guide (Oxford: Clarendon Press, 1999), 155. For a more detailed discussion, see also G. O'Daly and A. Zumkeller, "Affectus (passio, perturbatio)", in Augustinus-Lexikon (vol. 1), ed. C. Mayer (Basel: Schwabe, 1986), 166-180.

${ }^{20}$ Nisula 2012, 193 (n. 2).

21 "I shall speak of 'emotions' rather than 'passions' when rendering the Greek term pathē. This is for the reason given in the Introduction, that, in so far as there is a distinction nowadays, passion is thought of as a very strong type of emotion". Sorabji 2000, 17. He prefers the term "emotion" in discussing ancient Latin psychology as well.

${ }^{22}$ See, for example, Wiesen's Loeb Classical Library translation. In some instances, he translates passio and affectus as "emotion" and "turbulentus affectus" as "violent emotion" in $C D$ 9.5. "Si enim mente ab his libera eisque dominante motus huiusce modi paterentur" in $C D 9.6$ is translated as follows: "The point is that if their minds remained free and in command of these emotions which they experience". However, in many places, he also translates passio as passion, perturbatio as perturbation, affectus as affection.
} 
modern term "passion" and that it is incorrect to translate passio simply as “passion". I shall examine Augustine's texts and his quotations from Hellenistic philosophers in order to analyse the use and characteristics of the term passio in Augustine's works and to consider whether they contain a systematic terminological distinction.

\section{Cases for passio as a negative term and affectus as a positive term}

As mentioned earlier, those who argue that Augustine uses passio (perturbatio) as a negative term maintain that it refers a perturbation of the soul or a movement of the soul's lower part. It seems that Augustine borrowed from ${ }^{23}$ the semantic views of the Stoics, Academics, and Cicero who regarded passio as a perturbation or mental agitation. Augustine equates Cicero's term perturbatio with passio and pathos and interprets them to refer to mental agitation and perturbations of the soul that are contrary to reason:

...for the Greek word pathos means 'disturbance'; and this is what Apuleius means when he says that the demons are 'passive in soul', because the word passio, which is the same as pathos, signifies a commotion of the mind contrary to reason...when these disturbances occur in men, this is brought about by foolishness or misery; for we are not yet blessed by that perfection of wisdom which is promised to us at the end, when we shall be redeemed from this mortality. ${ }^{24}$

Moreover, Augustine follows the Platonic and Stoic doctrines of passions, classifying the types of passions into four subspecies which he refers to as the four perturbations: "all four of the most notable disturbances of the mind: desire and fear, joy and grief, which are the origin, as it were, of all sins and vices". ${ }^{25}$ Furthermore, Augustine also refers to these as being so influenced by earthy limbs

\footnotetext{
${ }^{23}$ Augustine presents similar arguments in De civitate Dei as Cicero does in Tusculanae disputationes, which cites examples from other philosophers before presenting his own different opinions.

${ }^{24}$ CD 8.17: ...perturbatio est enim quae Graece $\pi \dot{\alpha} \theta o \varsigma$ dicitur; unde illa voluit vocare animo

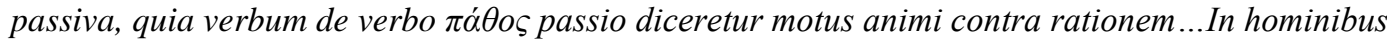
autem ut sint istae perturbationes, facit hoc stultitia vel miseria; nondum enim sumus in illa perfectione sapientiae beati quae nobis ab hac mortalitate liberates in fine promittiture. Similar statements can be found in Cicero's Tusc. 3.4.7: Num reliquae quoque perturbationes animi, formidines, libidines, iracundiae? Haec enim fere sunt eius modi, quae Graeci $\pi \alpha ́ \theta \eta$ appellant; ego poteram morbos et id verbum esset e verbo, sed in consuetudinem nostram non caderet: nam misereri, invidere, gestire, laetari, haec omnia morbos Graeci appellant, motus animi rationi non obtemperantes; nos autem hos eosdem motus concitati animi recte, ut opinor, perturbationes dixerimus, morbos autem non satis usitate, nisi quid aliud tibi videtur.

${ }^{25}$ CD 14.3: ...omnesque illas notissimas quattuor animi perturbationes, cupiditatem timorem, laetitiam tristitiam, quasi origines omnium peccatorum atque vitiorum.
} 
and dying members, "that they derive from them their unwholesome desires and fears and joys and sorrows. And these four 'perturbations' (as Cicero calls them) or 'passions' (which is the usual term, rendered exactly from the Greek), embrace all the vices of human conduct". ${ }^{26}$ Augustine also quotes many similar views from the Platonists, Stoics and Peripatetics, which indicate that he possessed a considerable knowledge of his predecessors, often acquired through Cicero's writings. ${ }^{27}$ Therefore, in some places, Augustine adopts the traditional Stoic approach by using passio or perturbatio in a negative context and contrasts this by using affectus in a positive one. For instance:

(a) Hoc enim esse volunt in potestate idque interesse censent inter animun sapientis et stulti, quod stulti animus eisdem passionibus cedit atque adcommodat mentis adsensum; sapientis autem, quamvis eas necessitate patiatur, retinet tamen de his quae adpetere vel fugere rationabiliter debet veram et stabilem inconcussa mente sententiam. ${ }^{28}$ (CD 9.4)

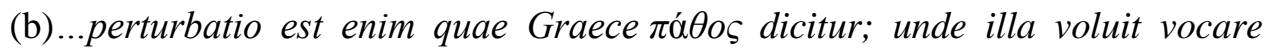
animo passiva, quia verbum de verbo $\pi \dot{\alpha} \theta$ os passio diceretur motus animi contra rationem. ${ }^{29}$ (CD 8.17)

(c)...quibus quattuor vel perturbationibus, ut Cicero appellat, vel passionibus, ut plerique verbum e verbo Graeco exprimunt, omnis humanorum morum vitiositas continetur. ${ }^{30}(C D$ 14.5)

(d)...confitens eorum mentem, qua rationales esse perhibuit, non saltem inbutam munitamque virtute passionibus animi inrationabilibus nequaquam cedere, sed ipsam quoque, sicut stultarum mentium mos est, procellosis quodam modo perturbationibus agitari. $^{31}$ (CD 9.3)

${ }^{26}$ CD 14.5: ... hinc eis sint morbi cupiditatum et timorum et laetitiae sive tristitiae; quibus quattuor vel perturbationibus, ut Cicero appellat, vel passionibus, ut plerique verbum e verbo Graeco exprimunt, omnis humanorum morum vitiositas continetur.

${ }^{27}$ For Augustine, the main channel for acquainting himself with this tradition were Cicero's writings. It has been stated that 750 out of the 1150 abstract nouns in De civitate Dei are from Cicero, which illustrates that Cicero had a significant influence on Augustine. See Ruokanen 1993, 121.

28 "For such consent, they hold, is within our power; and the difference between the mind of a wise man and that of a fool is that the fool's mind yields to these same passions and adapts them through an assent, whereas the wise man, though he experiences them of necessity, nonetheless retains with mind unshaken a true and steadfast perception of those things which he ought rationally to seek or avoid". [transl. Dyson, with changes]

29 "For the Greek word pathos means 'disturbance'; and this is what Apuleius means when he says that the demons are 'passive in soul', because the word passio, which is the same as pathos, signifies a commotion of the mind contrary to reason".

30 Translated above; see note 26.

31 "For he confesses that their minds, in respect of which he has asserted that they are rational, are 
(e) Hi motus, hi affectus de amore boni et de sancta caritate venientes si vitia vocanda sunt, sinamus ut ea quae vere vitia sunt virtutes vocentur. Sed cum rectam rationem sequantur istae affectiones quando ubi oportet adhibentur, quis eas tunc morbos seu vitiosas passiones audeat dicere? ${ }^{32}$ (CD 14.9)

In (a), (b), (c), and (d), Augustine adopts, through Cicero, the Stoic orientation to passions (passiones) and interprets them as perturbations of the soul and the opposite of reason. Scrutton maintains that Augustine attaches affectus to voluntas and passio to concupiscentia or appetitivus, the lower sensitive part which is in rebellion against the higher part of the soul, and renders the term voluntas as a criterion to distinguish between affectiones and passiones. ${ }^{33}$ Referring to case (e), Scrutton emphasises that affections are movements of the rational soul and further that "what makes an emotion a passion or an affection is not its moral status, but what it relates to the sensitive or intellective self". ${ }^{34}$ This argument involves two facets that occur in the Stoics and Cicero: 1. Passions are the psychological motions or perturbations of the soul (in Zeno). ${ }^{35}$ 2. Passions as mistaken value judgments can be judged by good and bad (in Chrysippus). ${ }^{36}$ Cicero adopts these two Stoics ideas in his works and uses the term perturbatio instead of passio to refer to a disturbance or a movement of the soul against reason. ${ }^{37}$ These perturbations (gestiens et libido, metus et aegritudo) can be

not imbued and fortified even with sufficient virtue to resist to any degree the irrational passions of the soul. Rather, they are themselves agitated by storms and tempests, as it were, as is usually the case with stupid minds".

32 "If these emotions and affections, which come from love of the good and from holy charity, are to be called vices, then let us allow that real vices should be called virtues. But since, when they are exhibited in the proper circumstances, these affections are the consequences of right reason, who would then dare to say that they are unwholesome or vicious passions?"

${ }^{33}$ See Scrutton 2005, 171.

${ }^{34}$ Scrutton 2005, 172.

35 This is a basic part of the Stoic doctrine of passions, widely known as $\pi \dot{\alpha} \theta \eta$. Zeno defined them as impulses or an instability in the movements of the soul. In Lives of Eminent Philosophers (Vol. II), Zeno 7.110, Diogenes Laertius comments on Zeno's viewpoint of passions: "Passion, or emotion, is defined by Zeno as an irrational and unnatural movement in the soul, or again as impulse in excess". [transl. Hicks, LCL version] Cicero also points this out in Tusc. 4.6.11: Est igitur Zenonis haec definitio, ut perturbatio sit, quod $\pi \dot{\alpha} \theta$ os ille dicit, aversa a recta ratione contra naturam animi commotio. Quidam brevius perturbationem esse appetitum vehementiorem, sed vehementiorem eum volunt esse, qui longius discesserit a naturae constantia.

${ }^{36}$ Chrysippus refers to emotions as judgments, as Diogenes Laertius explains in Lives of Eminent Philosophers (Vol. II), Zeno 7.111: "They hold the emotions to be judgments, as is stated by Chrysippus in his treatise On the Passions: avarice being a supposition that money is a good, while the case is similar with drunkenness and profligacy and all the other emotions [against reason]". [transl. Hicks]

${ }^{37}$ See Cicero Tusc. 3.9.24: Nam cum omnis perturbatio sit animi motus vel rationis expers vel rationem aspernans vel rationi non obediens, isque motus aut boni aut mali opinione citetur 
classified into four categories depending on whether the evaluations are about the present or the future, good or bad; they are all nevertheless obstacles to maintaining one's mental peace and quiet. Augustine was well familiar with these doctrines, and case (e) might be construed as evidence by commentators who defend the dichotomous theory of passions and affections.

However, these are merely preliminary examples that do not cover all cases and consequently do not provide a satisfactory account of Augustine's semantics of emotions terminology. Augustine does not simply confine himself to this portrayal. While he does occasionally associate a negative value with passio and a positive one with affectus when discussing the views of the Stoics, Academics and Cicero, he also uses the terms passio, affectus, and perturbatio in a more complex way, highlighting their flexible characters. An important observation is that all of these terms are used both in a positive and in a negative sense.

\section{Cases for flexible uses of passio, affectus and other related terms}

Augustine displays a versatile use of the terms passio and affectus; in many instances, he even refers to a positive sense of passio and a negative sense of affectus. I shall demonstrate this semantic flexibility through examining the following four examples: 1. Cases in which Augustine uses passio in a positive sense and affectus in a negative sense, or both in a neutral sense; 2. Cases in which Augustine uses passio, perturbatio, affectio, pathē interchangeably and regards them as having the same meaning when used by different philosophers to describe the movement of the soul; 3. Cases in which Augustine discusses the four subspecies of passio, namely, cupiditas, timor, laetitia and tristitia, which he considers to be derived from the traditional division by the Stoics, and refers to them as being good or evil. Augustine unambiguously states that he disagrees with the Stoics on the issue of distinguishing the constantiae ( $\varepsilon \dot{v} \pi \alpha \theta \varepsilon i \tilde{\alpha}$, with the three subtypes of voluntas, gaudium, cautio) from the perturbationes (passiones or $\pi \dot{\alpha} \theta \eta$, with the four subspecies of cupiditas, laetitia, metus, tristitia) and

bifariam, quattuor perturbationes aequaliter distributae sunt: nam duae sunt ex opinione boni, quarum altera, voluptas gestiens, id est, praeter modum elata laetitia, opinione praesentis magni alicuius boni, altera, quae est immoderata appetitio opinati magni boni rationi non obtemperans, vel cupiditas recte vel libido dici potest. Ergo haec duo genera, voluptas gestiens et libido, bonorum opinione turbantur, ut duo reliqua, metus et aegritudo, malorum. 
establishing the members of the first group as being good, as the members of these two groups, constantiae and passiones, can be good and bad alike; ${ }^{38} 4$. Cases in which Augustine uses passio in a positive sense and equates affectus with passio in this context, referring to religious manners or the psychology of Jesus Christ. He stresses the importance of the emotion of "secundum Deum contristari" (grief after a godly manner) in $C D$ 14.8, and suggests that we should distinguish secundum Deum contristari from mundi tristitia. ${ }^{39}$ By examining these four aspects of Augustine's terminology, we will see that Augustine uses the terms passio (incl. subspecies of passio) and affectus in several ways and in opposite value contexts rather than according to a fixed dichotomy that some scholars have maintained.

1. Using passio in a positive sense and affectus as having a negative connotation, or using these in a neutral sense in some occasions.

(a) Quod passiones quae Christianos animos afficiunt non in vitium trahant, sed virtutem exerceant. ${ }^{40}(C D$ 9.5)

(b) Deus secundum scripturas irascitur, nec tamen ulla passione turbatur. Hoc enim verbum vindictae usurpavit effectus, non illius turbulentus affectus. ${ }^{41}$ (CD 9.5)

(c)...ut sine his affectionibus vivatur quae contra rationem accidunt mentemque perturbant. $^{42}$ (CD 14.9)

(d) Et omnino pro varietate rerum quae appetuntur atque fugiuntur, sicut allicitur vel offenditur voluntas hominis, ita in hos vel illos affectus mutatur et vertitur. ${ }^{43}$ (CD 14.6)

(e)...iuvandam mentique passiones ita moderandas atque frenandas ut in usum

\footnotetext{
38 CD 14.8: Proinde volunt cavent gaudent et boni et mali; atque ut eadem aliis verbis enuntiemus, cupiunt timent laetantur et boni et mali. Sed illi bene, isti male, sicut hominibus seu recta seu perversa voluntas est.

${ }^{39}$ CD 14.8: Ita enim dicit: Video quod epistula illa, etsi ad horam, contristavit vos; nunc gaudeo, non quia contristati estis, sed quia contristati estis in paenitentiam. Contristati enim estis secundun Deum, ut in nullo detrimentum patiamini ex nobis. Quae enim secundum Deum est tristitia paenitentiam in salutem inpaenitendam operatur; mundi autem tristitia mortem operatur. Ecce enim id ipsum secundum Deum contristari quantam perfecit in vobis industriam.

40 "That the passions which affect the minds of Christians do not drag them into vice but exercise their virtue". [transl. Wiesen, LCL version] This is the title of $C D$ 9.5. The chapter headings in the City of God may be by Augustine or later additions; they are included in the critical edition by B. Dombart and A. Kalb in a separate list (See CCL 47, V-XLV).

41 "According to the Scriptures, God Himself is angered; yet He is not disturbed by any passion. For this word is used to indicate the effect of His vengeance, rather than any disturbance to which He is subject".

42 “...a life without those affections which come contrary to reason and agitate the mind". [My translation]

43 “And, universally, as a man's will is attracted or repelled by the variety of things which are pursued or avoided, so it changes and turns into emotions of one kind or the other".
} 
iustitiae convertantur. ${ }^{44}(C D 9.5)$

Example (a) shows that for Christians, passions constitute good exercises in fostering virtues. Augustine explains that it is necessary for a right-minded person to have compassion to comfort the unfortunates and preserve righteousness. ${ }^{45}$ In this context, passions are regarded as being good because they follow the right reason. Examples (b) and (c) demonstrate a negative use of affectus, referring to that which takes place contrary to reason (ratio). Examples (d) and (e) show that affectus and passio are used as neutral terms referring to natural emotions or dispositions of the mind.

2. Using passio, affectio, perturbatio, and pathe interchangeably.

(a) Duae sunt sententiae philosophorum de his animi motibus, quae Graeci $\pi \dot{\theta} \theta \eta$, nostri autem quidam, sicut Cicero, perturbationes, quidam affectiones vel affectus, quidam vero, sicut iste, de Graeco expressius passiones vocant. ${ }^{46}$ (CD 9.4)

(b)...has autem quattuor perturbationes secundum Ciceronem, secundum autem plurimos passiones. Graece autem illae tres, sicut dici, appellantur عi் $\alpha \theta \varepsilon i ̃ \alpha l$, istae autem quattuor $\pi \dot{\alpha} \theta \eta \cdot{ }^{47}$ (CD 14.8)

(c)...quibus quattuor vel perturbationibus, ut Cicero appellat, vei passionibus... Unde, etiam illis fatentibus, non ex carne tantum afficitur anima ut cupiat metuat, laetetur aegrescat, verum etiam ex se ipsa his potest motibus agitari. ${ }^{48}$ (CD 14.5)

(d) Has ergo perturbationes sive affectiones sive passiones quidam philosophi dicunt etiam in sapientem cadere, sed moderatas rationique subiectas. ${ }^{49}$ (CD 9.4)

In excerpt (a), Augustine assumes that all these terms can be used synonymously. The same is said to apply to the terms passio and perturbatio in excerpts (b) and (c) as well as the terms perturbatio and affectus in excerpt (d).

\footnotetext{
44 “...places the mind itself under the governance and help of God, and the passions under the mind, so that they may be moderated and bridled and turned to righteous use".

${ }^{45}$ CD 9.5: Servit autem motus iste rationi quando ita praebetur misericordia ut iustitia conservetur, sive cum indigenti tribuitur, sive cum ignoscitur paenitenti.

46 "There are two opinions among the philosophers about those motions of the mind which the Greeks call pathe. Some of our writers such as Cicero calls them disturbances, others call them affections or affects, and others again, [like Apuleius], call them passions, which expresses the Greek word more closely". [transl. Dyson, with changes]

47 “...the latter four are 'disturbances' according to Cicero, but 'passions' according to most other authors. In Greek, however, as I have said, the three former are called eupatheiai; and the four latter are called pathe".

48 "And these four perturbations, as Cicero calls them, or passions...Thus, even by their own admission, the soul is not only so affected by the flesh that it feels desire and fear, joy and grief, but it can also through itself be stirred by these emotion".

49 "Then, these perturbations or affections or passions are said by certain philosophers to assail even the wise man, though they are moderated and controlled by reason". [My translation]
} 
3. Commenting on the four subspecies of emotional terms, cupiditas, laetitia, metus and tristitia as well as on the ambiguity of the so-called constantiae. Quoting from the Holy Scripture (ex propheta et ex evangelio), Augustine argues that voluntas, gaudium, cautio, and the four subspecies of passio can be expressed in both a positive and a negative sense.

(a) Laetitia in bono est: Laetamini in Domino et exultate iusti; et: Dedisti laetitiam in cor meum; et: Adimplebis me laetitia cum vultu tuo. Timor in bono est apud apostolum ubi ait: Cum timore et tremore vestram ipsorum salutem operamini; et: Noli altum sapere, sed time..$^{50}(C D$ 14.7)

(b) Locutione vero usitatiore, quam frequentat maxime consuetudo sermonis, non utique diceretur: Noli velle mentiri omne mendacium, nisi esset et voluntas mala...Nam ex abundanti additum est 'bonae' si esse non potest nisi bona. ${ }^{51}$ (CD 14.8)

(c) Gaudium vero eos et in malo posuisse ille ipse Vergilianus testis est versus ubi has quattuor perturbationes summa brevitate complexus est: Hinc metuunt cupiuntque, dolent gaudentque. Dixit etiam idem auctor: Mala mentis gaudia. ${ }^{52}$ (CD 14.8)

(d) Proinde volunt cavent gaudent et boni et mali; atque ut eadem aliis verbis enuntiemus, cupiunt timent laetantur et boni et mali. Sed illi bene, isti male, sicut hominibus seu recta seu perversa voluntas est. ${ }^{53}$ (CD 14.8)

These samples illustrate that Augustine prefers to use the same terms to refer to both good and bad psychological phenomena and does not differentiate these on the basis of value categories. Augustine states that "such an indiscriminate use of these terms is seen also among authors of secular literature". ${ }^{54}$ Augustine disagrees with the Stoics who believed that passions are simply bad and cannot exist in a wise man. He maintains that passions (cupiditas,

\footnotetext{
50 “'Joy' has a good sense, as in, 'Have joy in the Lord, and rejoice, ye righteous', and 'Thou hast put joy in my heart'; and 'Thou wilt fill me with joy by Thy countenance.' 'Fear' has a good sense in the place where the apostle says, 'Work out your own salvation with fear and trembling', and 'Be not high-minded, but fear"',

51 "If there were no such thing as an evil will, there would not be the more familiar usage which is very frequently employed in ordinary speech, as in, "Let it not be thy will to make any manner of lie'...The addition of the word 'good' here is redundant if will can only be good".

52 "'Gladness' is used in a bad sense in that same line of Virgil which contains his most brief statement of the four things which disturb the mind: 'Hence come desire and fear, gladness and sorrow.' The same author also speaks of "The evil gladness of the mind"”.

53 "Will, caution and gladness, then, are common to both good and evil men; and - to make the same point in different words - good and evil men alike feel desire, fear and joy. But the good feel these emotions in a good way, and the bad feel them in a bad way, just as the will of men may be righteous or perverse".

${ }^{54}$ CD 14.8: Et apud auctores saecularium litterarum talis istorum verborum indifferentia reperitur.
} 
laetitia, metus, tristitia) can also be good. For example, he states that "although the Stoics find nothing in the mind of the wise man corresponding to grief, we discover that even this is used in a good sense, and especially in our own Scriptures". 55

4. Godly passions play an important role in Augustine's works. They are based on human emotions. In the life of Christians or Christ, passio is referred to in a morally good sense, as are the four subspecies of passio (cupiditas, laetitia, metus, tristitia). Augustine asserts strongly that if a person were grieved in a godly manner (secundum Deum contristari), he or she would not suffer any loss, ${ }^{56}$ because a godly grief affects repentance which in turn leads to salvation ( $C D$ 14.8: Quae enim secundum Deum est tristitia paenitentiam in salutem inpaenitendam operatur). ${ }^{57}$ Human passions are good in the person of Christ who experiences gladness, desire, grief and pain in a humble and righteous manner:

Quod dixerit: Gaudeo propter vos ut credatis; quod Lazarum suscitaturus etiam lacrimas fuderit; quod concupiverit cum discipulis suis manducare pascha; quod, propinquante passione, tristis fuerit anima eius, non falso utique referuntur. Verum ille hos motus certae dispensationis gratia ita... ${ }^{58}$ (CD 14.9)

Augustine continues to maintain that the passions of Christians are right in this life if they follow God's will. ${ }^{59}$ Having godly passions, Christians are able to feel the joy of hope and defeat death. Thus, godly passions belong to the way of life that human beings in this world ought to pursue. From this perspective, passio is a positive term that is used to refer to all the emotions in the heart of Jesus as well as all the emotions that Christians will go through. On the basis of the above cases demonstrating the flexible use of emotions terminology, it is clear that the notion of a sharp division between the terms passio and affectus is false.

\footnotetext{
${ }^{55}$ CD 14.8: Ipsa quoque tristitia, pro qua Stoici nihil in animo sapientis inveniri posse putaverunt, reperitur in bono et maxime apud nostros.

${ }^{56}$ CD 14.8: Contristati enim estis secundun Deum, ut in nullo detrimentum patiamini ex nobis.

57 "For godly grief worketh repentance to salvation not to be repented of: but the grief of the world worketh death". Cf. I Cor. 7:8ff.

58 “That He said: 'I am glad for your sakes, to the intent ye may believe'; that He even wept when $\mathrm{He}$ was about to raise Lazarus; that He desired to eat the Passover with His disciples; and that, as His passion drew nigh, His soul was grieved. Truly, He accepted these emotions into His human mind for the sake of His own assured purpose..."

${ }^{59}$ CD 14.9: Apud nos autem iuxta scripturas sanctas sanamque doctrinam cives sanctae civitatis Dei in huius vitae peregrinatione secundum Deum viventes metuunt cupiuntque, dolent gaudentque, et quia rectus est amor eorum, istas omnes affectiones rectas habent.
} 


\section{Cases for using passio, affectus and other terms to express all emotions}

Let us turn to the argument that one should not use the term "emotion" in the context of Augustinian studies because there is no relevant Latin word in Augustine's works that could be rendered as "emotion", as it is used today. Yet it can be observed that Augustine occasionally uses the terms affectus (affectiones), motus, or passio to express the felt movements of a human soul that do not occur by choice. In light of this general usage, I do not foresee a strong reason against referring to these movements as emotions. If one uses "passion" as a generic term similar to "emotion", it can be likewise regarded as an abstract expression. In both instances, some contrastive uses of passio and affectus must be noted.

(a) Quae cum ita sint, quoniam recta vita ducenda est qua perveniendum sit ad beatam, omnes affectus istos vita recta rectos habet, perversa perversos. ${ }^{60}$ (CD 14.9)

(b) ...vituperabat enim et detestabatur apostolus quosdam quos etiam esse dixit sine affectione. ${ }^{61}$ (CD 14.9)

(c) Proinde, quod fatendum est, etiam cum rectas et secundum Deum habemus has affectiones, huius vitae sunt, non illius quam futuram speramus, et saepe illis etiam inviti cedimus. ${ }^{62}$ (CD 14.9)

(d) Quam ob rem etiam ipse Dominus in forma servi agere vitam dignatus humanam, sed nullum habens ominino peccatum adhibuit eas ubi adhibendas esse iudicavit. Neque enim in quo verum erat hominis corpus et verus hominis animus, falsus erat humanus affectus. ${ }^{63}$ (CD 14.9)

(e) Verum ille hos motus certae dispensationis gratia ita, cum voluit, suscepit animo humano ut, cum voluit, factus est homo. ${ }^{64}$ (CD 14.9)

(f) Hi motus, hi affectus de amore boni et de sancta caritate venientes si vitia vocanda sunt, sinamus ut ea quae vere vitia sunt virtutes vocentur. ${ }^{65}$ (CD 14.9)

\footnotetext{
60 "We must, then, lead a righteous life if we are to attain a life of blessedness; and such a righteous life will exhibit all these emotions [affectus] righteously, whereas a perverse life exhibits them perversely".

61 "For the apostle condemned and denounced certain persons who, he said, were 'without affection"”. [transl. Dyson, with changes]

62 "We must, however, confess that the emotions [affectiones] which we have, even when they are righteous and according to God, belong to this life, and not to the life to come for which we hope; and that we often yield to them even against our will".

63 "Hence, when the Lord Himself deigned to live a human life in the form of a servant, though having no sin, He displayed these emotions in circumstances where He judged that they ought to be displayed. For human emotions [affectus] was not feigned in Him Who truly had the body of a man and the mind of a man".

64 "Truly, He accepted these emotions [motus] into His human mind for the sake of His own assured purpose, and when He so willed, just as He was made man when He so willed".

65 "If these emotions [motus] and affections [affectus], which come from love of the good and 
(g) Has ergo perturbationes sive affectiones sive passiones quidam philosophi dicunt etiam in sapientem cadere, sed moderatas rationique subiectas. ${ }^{66}$ (CD 9.4)

(h) Deo quippe illa ipsam mentem subicit regendam et iuvandam mentique passiones ita moderandas atque frenandas ut in usum iustitiae convertantur. ${ }^{67}$ (CD 9.5)

(i) Deus secundum scripturas irascitur, nec tamen ulla passione turbatur. Hoc enim verbum vindictae usurpavit effectus, non illius turbulentus affectus. ${ }^{68}$ (CD 9.5)

Excerpts (a), (b), (c), and (d) demonstrate that affectus (affectiones) may be used to refer to all the emotions that are present in human beings and also in Jesus. Affectus is not good or bad as such, but rather an emotion that can be either depending on the context. Likewise, excerpts (e) and (f) show the equalisation between motus and affectus, which can also be discerned in excerpt (g) between perturbatio, affectus and passio. In excerpt (h), the term passiones refers to all the emotions which should be moderated and controlled by the mind, while in excerpt (i), passio and affectus refer to all human emotions to which God is not subject. In summary, these examples show that there are no fixed distinctions between the uses of motus, perturbatio, passio and affectus when referring to the emotions that are shared by human beings.

On the basis of the above considerations, we can observe that Augustine displays a good understanding of how Cicero and the Stoics use the term perturbatio (passio). He follows their doctrine that regards passions as the motion, turmoil or perturbation of the mind, but he examines the idea from a new perspective by focusing on the inevitable movements of the soul (motus animi) which are natural human emotions and also shared by Jesus. There is no strict

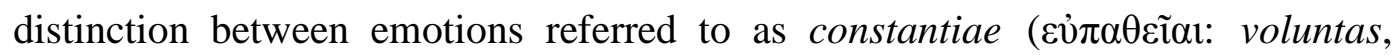
gaudium, cautio) and those referred to as perturbationes (passio or $\pi \dot{\alpha} \theta \eta$ : cupiditas, laetitia, metus, tristitia) in Augustine's works, and he also uses these terms in different ways. Therefore, the assertion that he differentiates between passio (perturbatio) and affectus as two opposite groups is not completely substantiated by evidence and is unconvincing.

from holy charity, are to be called vices, then let us allow that real vices should be called virtues".

66 Translated above; see note 49.

67 "Scripture, indeed, places the mind itself under the governance and help of God, and the passions under the mind, so that they may be moderated and bridled and turned to righteous use".

68 Translated above; see note 41 . 
In addition, the flexible terminological use of the emotional terms passio (incl. its subspecies), affectus, motus, and perturbatio as well as the remarks on the godly passiones support the suggestion that these phenomena could well be referred to by the common term "emotion" that we often use today. Cicero translates the Stoic word for emotion, "pathos", by the term perturbatio. ${ }^{69}$ Augustine also assumes that the term perturbationes in Cicero and the Stoics refers to all passiones in the sense of $\pi \dot{\alpha} \theta o \varsigma$, but he changes the unqualified negative connotation of the Stoic terminology. The discussion concerning passio in Augustine's works reveal his complex doctrinal relationship with the Stoics, Cicero and other Hellenistic philosophers. Next, I shall explore the doctrinal background of Augustine's psychology of passions, concentrating on the question of which theoretical sources Augustine consulted.

\subsection{Augustine and His Predecessors on the Psychology of Passions}

Stoicism and Neoplatonism are the two philosophical schools that served as major influences on Augustine's understanding of the passions. ${ }^{70}$ Some scholars assert that Augustine primarily follows Neoplatonic theories of passions and that his viewpoint is more in line with Platonism than with Stoicism. On the other hand, other scholars insist that Augustine follows the Stoic tradition. By way of an example, I shall first explain the Platonist interpretation by Van Riel as well as the Stoic interpretation by Marcia Colish.

Gerd Van Riel maintains that Augustine displays a clear adherence to the Neoplatonic creed of passions. In his article, "MENS INMOTA MOTA MANE: Neoplatonic Tendencies in Augustine's Theology of the Passions", Van Riel

\footnotetext{
${ }^{69}$ Sorabji 2000, 208. Peter King also supports this viewpoint and believes that Augustine follows Cicero's usage: "Cicero even proposes morbus as literal translation of $\pi \dot{\alpha} \theta o \varsigma$, though in the end he adopts 'disturbance' (perturbatio), in which he is later followed by Augustine”. See King 2012a, 14 and n. 15.

70 Augustine's knowledge of Stoicism is acquired predominately through Cicero, but the question of Augustine's Platonic sources is somewhat more complicated. Although he mentioned Platonism at different stages, the time he spent in Milan and Rome was important in this respect. Peter Brown points out that some works of Christian Platonists such as Marius Victorinus (an African professor of rhetoric), Simplicianus (the teacher of Ambrose), Ambrose, and earlier pagan writers such as Plotinus (in the Latin translation by Marius Victorinus) and Porphyry (a lost work De Regressu Animae) influenced Augustine's comprehension of Platonism during the year 386. See Brown 2000, 83-85. However, Cicero's comments on Platonism also influenced Augustine. Therefore, I shall also focus on Cicero's influence on Augustine's concept of emotions in this section.
} 
maintains that Plato, Plotinus, Porphyry, Virgil, and Aristotle have a profound influence on Augustine's conception of passions, which includes the function of the sensory soul, the physiological basis, and the operations of passions in both this life and the afterlife. He also argues that when Augustine absorbs some scattered points from Stoicism, they are interpreted from a Neoplatonic perspective. ${ }^{71}$ Van Riel points out that some Stoics (such as Posidonius) even abandon their standard theory and return to the Platonic camp, which serves to illustrate how Platonism tends to dominate in Augustine as well. In what follows, I shall list those Platonic-Aristotelian or Neoplatonic doctrines that Van Riel considers to have in one way or another influenced Augustine's orientation on passions. It is important to note that when Van Riel argues for Augustine's Neoplatonic tendency, he focuses more on the philosophical and doctrinal relationship between Augustine and his Platonic-Aristotelian predecessors than on their historical connection. Therefore, when Van Riel lists relevant documents for comparison, he primarily focuses on similarities instead of genetic connections, although he does occasionally comment on the historical connections as well. The similarities he points out are the following:

(1) Plato (Philebus): There is a division between the body and the soul. The body is addicted to lust and material desires, and only the soul has the possibility to attain truth and perfection. When the corporeal movement is weak, the soul will not sense it and will be in a state of "neutral condition" or contentment without the perturbations of passions. In De quantitate animae and De musica 6.5.13 (and 15), Augustine accepts Plato's view of this division and the "neutral state" (Philebus 42c-44a) and that the soul reacts to any sufficiently intensive affects (or passio) from the body. ${ }^{72}$

(2) Plotinus (Enneades): There is not only a division between the body and the soul, but also between the sensible and the intelligible soul. Passions can only originate from the "ensouled body", which is the combination of a sensible soul

71 "Augustine's interpretation of Stoicism is mediated through Neo-Platonic doctrine". Van Riel 2004, 510 (n. 14).

${ }^{72}$ However, Augustine does not agree with Plato's view that the intensity of the physiological movements determines the alterations of the soul. Some physiological movements or pains, such as cancer, will not be perceived, but they will nevertheless disturb the soul. Van Riel argues that Augustine considered Plato to have linked perception too closely to a bodily explanation and moved to Plotinus' view of "consciousness". See Van Riel 2004, 512 (n. 15)-513. 
and body (in Enneades I 8, 15.14-18). ${ }^{73}$ The intelligible soul is the higher part of the soul which possesses cognition and knowledge of objects that are higher than sensible forms. In this "body-sensible-intelligible" structure, the soul's descent towards the corporeal impulse is the principal source of passions that serve as a link between bodily suggestions and the psychic "consciousness". In De musica 6.5.10, Augustine accepts the above views and expresses his adherence to Plotinus' notion of "consciousness" in Enneades IV, 4.20.18-20 and V, $1.12 .12-14 .^{74}$

(3) Porphyry (De abstinentia): Passions originate from the corporeal soul or sense perception which fixes the soul to bodily pleasures (De abstinentia I, 31 and 38). ${ }^{75}$ The soul cannot reject these passions, but it can shift its attention to avoid them. The attentio is a pivotal function of the higher soul, a good faculty to prevent the soul from dropping into the body. By ignoring the sensible world and remaining impassive to it, the soul is able to avoid passions. Porphyry quotes Plato's descriptions of this impassivity in Theaetetus (173c-174a) and explains it in De abstinentia I, 37. ${ }^{76}$ Van Riel thinks that Porphyry's conception of attentio is based on Plotinus' "consciousness" and that Augustine, in De musica 6.5.9-10, paraphrases this idea from Porphyry's De abstinentia I, 38 and $39 .{ }^{77}$

\footnotetext{
73 Ibid., 520.

${ }^{74}$ Van Riel uses the following example from De musica 6.5.10 to illustrate how the soul directs attention to the influence that the sensory organs cause: "At the moment, it is said that the soul sees, hears, smells, tastes or feels by touching; by these activities, it gladly associates with things appropriate to it, and painfully resists to what is not appropriate. These, I think, are the operations which the soul exhibits over against affects of the body, when the soul senses, without, however, undergoing the passive states themselves". Ibid., 511. This description shows similarities to the passages in Plotinus' Enneades quoted above, as Van Riel demonstrates on p. 514.

75 Van Riel points out that Porphyry inherits Plotinus' conclusion that passions are originated from the combination of the lower soul and the body, namely, the soul "nailed" to the body as Phaedo (83d) described it. Ibid., 520 and n. 38.

${ }^{76}$ De abstinentia I, 37: "In these words Plato says that one remains impassive to these things [i.e., the sensible world] and out of their reach, not by descending to them, but by not lowering oneself to any of them". Van Riel links this argumentation and Plato's Phaedrus (246c-d) to Augustine's Soliloquiae I, 14: Unum est quod tibi possum praecipere; nihil plus novi: penitus esse ista sensibilia fugienda, cavendumque magnopere, dum hoc corpus agimus, ne quo eorum visco pennae nostrae impediantur, quibus integris perfectisque opus est, ut ad illum lucem ab his tenebris evolemus: quae se ne ostendere quidem dignatur in hac cavea inclusis, nisi tales fuerint ut ista vel effracta vel dissoluta possint in auras suas evadere. Van Riel 2004, 517-518 (n. 30).

77 De musica 6.5.9-10: Et ne longe faciam, videtur mihi anima cum sentit in corpore, non ab illo aliquid pati, sed in eius passionibus attentius agere, et has actiones sive faciles propter convenientiam, sive difficiles propter inconvenientiam, non eam latere: et hoc totum est quod sentire dicitur. Referring to Porphyry's De abstinentia I, 38-39, Van Riel writes: "This Porphyrian $\pi \rho \circ \sigma \circ \chi \eta$, or attentio, is literally taken over by Augustine in his De musica". Van Riel 2004,
} 
(4) Virgil (Aeneid): Heroes may have emotional reactions that are manifest in the body (for example, shedding tears), but their soul can nevertheless remain unmoved and without passions. Van Riel draws attention to Virgil's sentence "mens inmota mota manet, lacrimae volvuntur inanes" (Aeneid IV, 449), quoted by Augustine in $C D$ 9.4.3, which in his opinion shows that whether due to moderation or eradication, there is no difference between Platonists and Stoics on the notion that the mind of heroes is not afflicted by passions. ${ }^{78} \mathrm{He}$ maintains that while Augustine is more inclined to Virgil and Cicero's view regarding the bipartition of the soul than the Stoic view of the soul as a united whole, they all suggest eliminating the disturbance of passions.

(5) Aristotle (Nicomachean Ethics): $\mu \varepsilon \tau \rho 10 \pi \alpha ́ \theta \varepsilon ı$ (metriopatheia) and gaudium. Augustine uses the Aristotelian concept of $\mu \varepsilon \tau \rho ı \pi \alpha ́ \theta \varepsilon 1 \alpha$ or "tempering the passions" to interpret the Stoic notion of $\varepsilon \dot{\pi} \pi \dot{\theta} \theta \varepsilon 1 \alpha$. Van Riel notes that in $C D$ 14.8, Augustine uses the Aristotelian idea of moderation and right reason

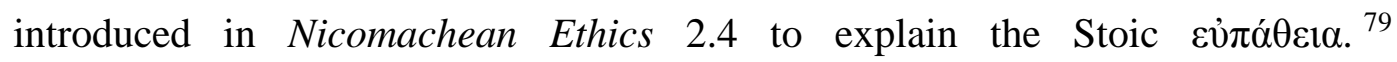
Furthermore, Augustine postulates two passions in the afterlife, joy (gaudium) and love (amor), which indicates that "he follows Aristotle rather than Plato. The notion of gaudium rests on the Aristotelian definition of pleasure as the supplementary effect of an unimpeded activity, namely, of the perfect activity of the will that has attained its final goal". ${ }^{80}$

(6) Posidonius (135-51 BC). Posidonius advocated a threefold division of the soul, dividing between the impulses of the soul as either irrational or rational; the irrational impulse produces passions, whereas the rational leads to $\varepsilon \dot{z} \pi \alpha \dot{\theta \varepsilon 1 \alpha}{ }^{81}$ Van Riel regards this as evidence of some Stoics rejecting their traditional view

$514-515$

${ }^{78}$ Ibid., 518 (n. 33).

79 "As a matter of fact, Augustine's reinterpretation is not Stoic at all any more. Rather, Augustine's viewpoint is in line with that of Aristotle, though expressed in a Stoic terminology". Ibid., 522. Metriopatheia (moderation of passions), which Cicero and Seneca refer to as a Peripatetic view, is often recommended by Platonic authors. See Knuuttila 2004, 88 .

${ }^{80}$ Ibid., 530-531.

81 "Posidonius strongly disagreed with the standard Stoic doctrine. He rejected Chrysippus' unitary view of the soul, and returned to the Platonic, threefold division of the psyche. He thus drew an opposition between reason and the irrational parts of the soul, which had important repercussions for the theory of passions... This was the version of Stoicism that was the most influential in the Platonic schools, and the Neo-Platonic reformulation rests on this Posidonian theory". Van Riel 2004, 523-524. This Platonic tendency of the Stoic Posidonius was rehashed by Galen and Plutarch who argued for a rejection of the classical Stoic theory of a unitary soul without a passionate part. 
and transferring to the Platonic idea of the bipartition of the soul, which influences Augustine deeply. Augustine applies this idea to reinterpret the Stoic terminology of $\varepsilon \dot{\pi} \alpha \dot{\theta} \theta \varepsilon 1 \alpha$, arguing that both $\varepsilon \dot{\pi} \pi \alpha \theta \varepsilon i \tilde{\alpha} \mathrm{l}$ and passions can be good as well as bad.

Peter King agrees with Van Riel's judgment that “Augustine's opposition to the Stoics stemmed from his deeper commitment to a 'Neoplatonic' account of the passions". ${ }^{82}$ King also draws attention to Augustine's comments on anger (ira) and lust (libido) in $C D 14.19$ to demonstrate that Augustine accepts the Platonic-Peripatetic theory of the bipartition of the soul and their view that turbulent passions (such as anger and lust) are the turmoil of the lower, irrational part of the soul: "those philosophers who have come closer to the truth than others have acknowledged that anger and lust are the vice-ridden parts of the soul, in that they are turbulent and disorderly emotions, inciting us to acts which reason forbids" ${ }^{83}$ King points out that the notion of the bipartition of soul that Augustine approves is derived from Plato (Republic 436a-441c) and Aristotle (Nicomachean Ethics 1.13 and Rhetoric 1.10). ${ }^{84}$

Some researchers, however, refer to other sources in order to demonstrate that Augustine's approach to passions is, in fact, rooted in the Stoic tradition. ${ }^{85}$ For example, Marcia Colish, Johannes Brachtendorf and Richard Sorabji emphasise this connection by foregrounding the doctrines of the structures and stages of passions. Marcia Colish maintains that Augustine is "the single most important figure in the history of the Stoic tradition in the Latin West between the third and the sixth centuries". 86 According to Colish, Augustine adheres to many

\footnotetext{
${ }^{82}$ King 2012a, 17 (n. 24). King believes that even though Augustine criticises some Neoplatonic notions, his Neoplatonic tendency is obvious. For detailed discussion, see King 2012a, 17-22.

${ }^{83}$ CD 14.19: Hinc est quod et illi philosophi qui veritati propius accesserunt iram atque libidinem vitiosas animi partes esse confessi sunt, eo quod turbide atque inordinate moverentur ad ea etiam quae sapientia perpetrari vetat, ac per hoc opus habere moderatrice mente atque ratione.

${ }^{84}$ King 2010, 171.

${ }^{85}$ Gérard Verbeke, Charles Baguette and Michel Spanneut present detailed surveys on Stoic passages and themes in Augustine. They believe that Augustine displays a strong attachment to the Stoic position in relation to semantics, epistemology, ethics, psychology and philosophy, among others, especially in his early works. See Gérard Verbeke, "Augusin et le stoïcisme", Recherches augustiniennes, I (1958), 67-89; Charles Baguette, Le stö̈cisme dans la formation de saint Augustin (Université de Louvain, Ph.D. diss. 1968), 256-260; Michel Spanneut, "Le stoïcisme et saint Augustin", Forma Futuri: Studi in onore del Cardinale Michele Pellerino (Torino, Bottega d'Erasmo, 1975), 896-914. For the studies, see Colish 1985 (II), 145-146.

${ }^{86}$ Colish 1985 (II), 142. Colish argues that Stoicism had a profound impact on Augustine throughout his life and that he employed their doctrines in his discussions on Christian dogma, ethics and other fields. "Augustine applies his consistent uses of Stoicism to a host of different types
} 
Stoic principles familiar to him, even though he occasionally criticises the Stoic philosophy. Colish lists the main Stoic predecessors that Augustine mentions or quotes. These influential Stoic thinkers are Zeno, Chrysippus, Aulus Gellius, Seneca, Epictetus, Persius, Cornutus, Lucan, Cincinnatus and Cato of Utica, ${ }^{87}$ of which the former five figures are the most relevant sources to Augustine's understanding of passions. Focusing on the different aspects of passions (perception, intellectual acts, and psychological state), Colish concludes that Augustine displays a clear adherence to the Stoic theory of passions. As evidence, the first point by Colish is that Augustine agrees with the Stoics that passions originate from the irrational, intellectual judgement of the mind which is located in the soul rather than in the body. ${ }^{88}$ In other words, Colish maintains that Augustine adopts the Stoic doctrine that a passion can only originate when the judgment of the mind is involved. This means that involuntary stimuli or first movements are not regarded as passions. The second point by Colish is that after the formation of passions, Augustine emphasises the importance of intellectual acts in the process of passions, especially a correct, intellectual control that promotes moral acts and virtues. This is also an important part of Stoicism. ${ }^{89}$ The third and final evidence that Colish mentions is that Augustine adopts the Stoic view of removing passions (or triumph over the passions) through correct judgement and will, which allows the soul tranquility and happiness (tranquillitas animi $).{ }^{90}$ In other words, Colish's position is very different from that of Van Riel. As regards passions, Colish argues that Augustine adheres to Stoic psychology

of works in a wide range of contexts...In some respects, also, his fidelity to Stoic positions is so thorough and is elaborated so repeatedly in this category of his thought as to make him their fullest expositor and transmitter to Latin readers in the later Middle Ages”. Ibid., 169, 152 and 213.

${ }^{87}$ Ibid., 166-167. Colish also emphasises the indirect connection between Augustine and the early Stoics such as Zeno, Chrysippus and Epictetus. She argues that Augustine's most detailed discussions on these early Stoics are presented in his early works such as Contra Academicos (for instance, in Contra Academicos 2.5.11-12, 2.6.14, Augustine supports Zeno's theory of phantasia). See Colish 1985 (II), 177-179.

88 "Augustine endorses their [the Stoic'] insistence that the passions arise from false intellectual judgments, similarly locating the passions in man's mind and will, not in his body". Ibid., 236.

89 "His [Augustine] endorsement of the idea that moral acts are primarily intellectual acts, not consequences of infrarational functions or material aspects of the human personality, informs his assent to the Stoic principle that virtues lies within, in the good conscience of the individual who possesses a correct moral intention”. Ibid., 209.

90 "The definition of summum bonum as virtue alone, as an end in itself, as attainable by correct intellectual judgments and the exercise of a rationally instructed will, as the sole and sufficient possession of the sage...is a constellation of Stoic ideas which Augustine expressly attributes to that school and toward which he shows a marked partiality in his earliest work". Ibid., 213. 
and further emphasises the following points:

(1) The Stoic theory of perception and the role of pneuma in psychology have a strong influence on Augustine. ${ }^{91}$ I shall not enter into the details of this notion; a more comprehensive account of the Stoic elements in Augustine's doctrines can be found in O'Daly 1987.

(2) Zeno of Citium ( $f l .300 \mathrm{BC}$ ). The mind or intellect judges the sense information it receives. Adopting the theory of pneuma, Zeno asserts that the cognitive sequence of truth-mind-phantasia (sensible image) eliminates false data: "Truth is impressed on the mind so accurately that the phantasia, or sensible image, bears the marks of such certitude as to rule out completely the possibility that it is false". ${ }^{92}$ Colish notes that Augustine gives an authentically Stoic description of this rational assessment in his Contra Academicos (2.5.11-12; 2.6.14; 3.9.18-3.11.26) and De musica. ${ }^{93}$

(3) Chrysippus (280-206 BC). Passions originate from the judgement of the intellect (they are false judgements), but if one relies on the capacity of reason when it functions without mistakes, it is possible to attain the optimal psychological state, summum bonum. Colish argues that Augustine consistently adheres to the Stoic creed that passions (laetitia, tristitia, cupiditas, metus) originate from the mind. This adherence is apparent in Augustine's De sermone Domine in monte 1.9.24 and De immortalitate animae 5.7. ${ }^{94}$ Furthermore, Colish points out that Augustine related this psychology to summum bonum (or finem boni) by intellectual contemplation, which is reflected in his early works such as Contra Academicos (1.2.5; 1.5.15; 1.8.22-23; 3.7.16-3.8.18) and De beata uita 2.4. Augustine accepts the assertion by Chrysippus that the mind serves a crucial function in generating passions as a type of judgement. ${ }^{95}$

\footnotetext{
${ }^{91}$ See Colish 1985 (II), 170.

92 Ibid., 178.

${ }^{93}$ In Contra Academicos (2.5.11-12; 2.6.14; 3.9.18-3.11.26), Colish notes that Augustine accepts this cognitive sequence and makes the intellectual judgment as a primitive criterion for the perception. Ibid., 178.

94 "...he [Augustine] insists over and over again that they [passions] originate not in the body but in the mind". Ibid., 207 and n. 168. Colish repeats this view on p. 236: "Augustine endorses their insistence that the passions arise from false intellectual judgments, similarly locating the passions in man's mind and will, not in his body".

95 "... on the nature of the summum bonum for the first time in his Contra Academicos Augustine clearly prefers the views of Zeno and Chrysippus...that man's capacity to know the truth with certainty is necessary for his understanding of the nature of the good life and of how to attain it". Ibid., 213.
} 
(4) Epictetus (AD 55-135) retailed by Aulus Gellius (Noctes Atticae). In $C D$ 9.4, Augustine cites the story of "Stoic fear in the storm" from the philosophical journalist Aulus Gellius. This story refers to the reflection lag between the arrival of the suggestions of phantasia and intellectual assessment. ${ }^{96}$ Noctes Atticae (19.1.14-20) paraphrases the argument from Epictetus' lost fifth book of Discourses that influences Augustine's comments in $C D$ 9.4.

On the basis of these doctrinal connections, Colish concludes that during his career, Augustine exhibits a clear orientation toward Stoicism. In other words, Augustine incorporated a large number of the Stoic categories, themes and doctrines of psychology in his works and these are all central and integrally connected to Augustine's concerns. ${ }^{97}$ Therefore, to Colish, Augustine displays a strong Stoic orientation in his psychology of passions, especially in certain aspects of his sense perception theory, intellectual functions (elevating the intellect over passions), and in the moral judgment of passions. ${ }^{98}$

According to Brachtendorf, Cicero follows the Stoic orthodoxy on the subject of the definition and character of passions ${ }^{99}$ and that his Tusculanae disputationes serves as a significant source for Augustine. ${ }^{100}$ Cicero sharply refutes the Platonic-Peripatetic doctrine that passions belong to the irrational part of the soul that could be beneficial to virtues, and he regards this approach involving moderation as a scandal. Cicero supports the orientations proposed by Zeno and Chrysippus, criticising each of the passions as a disease, and argues for

96 “...he [Augustine] agrees wholeheartedly in the passage just noted that intellectual judgment and assent to the data that the senses supply is needed to ascertain the truth and to govern one's moral responses to that truth". Ibid., 179.

97 "... This category encompasses the largest number of Stoic doctrines found anywhere in Augustine's oeuvre and includes physics, logic, epistemology, psychology, rhetoric, and ethics. Here, his treatment of his Stoic materials remains constant across his career although he may emphasize one aspect of a particular doctrine or another depending on the situation in which he uses it". Colish 1985 (II), 152-153.

98 Ibid., 208-209. Colish presents a detailed survey of Augustine and the Stoics' views on passions, but her assertion that Augustine adheres to the Stoic position and is "their fullest expositor and transmitter to Latin readers in the later Middle Ages" appears problematic. Colish focuses predominately on Augustine's early works (before the mid-390s), arguing that while Augustine was faithful to the Stoic intellectual tradition throughout his life, he also deviated from some particular Stoic doctrines in his later ideas. For example, he gave up the Stoic view on apatheia (see Colish 1985 (II), 221-225). I shall return to this issue in Chapter 3.4.

99 "Nonetheless Cicero abides by Stoic orthodoxy when he defines $\pi \dot{\alpha} \theta 0 \varsigma$, or perturbatio. Quoting Zeno, the founder of the Stoic school, he says: A perturbatio is a motion of the soul averted from right reason and against the nature of soul. It is too strong a desire and too far from the constancy of nature". Brachtendorf 1997, 292.

${ }^{100}$ For Tusculanae disputationes as a main source for Augustine's knowledge of the Stoic theory of emotions, see Hagendahl 1967 (vol. 2), 511-514; O’Daly 1987, 50-52. 
apatheia as tranquility of the soul. ${ }^{101}$ Brachtendorf cites the following examples of the influence of Cicero's Stoic theory of passions on Augustine:

(i) The terminology of emotions in Tusculanae disputationes (3.11.24-25; 4.6.11) such as $\pi \dot{\alpha} \theta \eta$, perturbatio, affectio, and affectus as well as Zeno's definition and quartation theory of $\pi \dot{\alpha} \theta o \varsigma$ (libido, laetitia, metus, aegritudo). Augustine mentions these words and adds Apuleius' neologism, passiones, in $C D$ 9.4. ${ }^{102}$

(ii) Passions are illnesses. Cicero maintains that passions are perturbations of the soul that are neither natural nor necessary. ${ }^{103}$ Augustine describes the condition of his soul in Confessiones $(8.11 .25$; 8.6.13; 8.10.24; 8.7.17) as an illness (morbus concupiscentiae) that should be healed; this conception has been influenced by Cicero's discussion on Alcibiades' passion in Tusc. 3 and $4 .{ }^{104}$ The characterisation of passions as illnesses is also introduced by Augustine in his $C D$ (9.3-6; 14.5-24) and De nuptiis et concupiscentia 1.23, making a connection between passions and $\sin .^{105}$

(iii) All passions are "directions of will". Cicero believes that the four subtypes of pathos are consents of a person's will (voluntas), each reflecting different passions. Moreover, the emotional movements of the soul are derived from wrong judgements about things according to the will. This idea is also adopted by Augustine in $C D$ 14.6. ${ }^{106}$

(iv) Apatheia. Augustine does not claim that apatheia could be attained in this life, but that it "was real in the earthly paradise, and it will be real again in the afterlife with God". ${ }^{107}$ The Stoic ideal of apatheia as a freedom from passions

101 Tusc. 4.6.11: Est igitur Zenonis haec definitio, ut perturbatio sit, quod ille dicit, aversa a recta ratione contra naturam animi commotio. Tusc. 4.9.23: Hoc loco nimium operae consumitur a Stoicis, maxime a Chrysippo, dum morbis corporum comparatur morborum animi similitudo. Brachtendorf 1997, 292-293.

102 Brachtendorf 1997, 296.

103 Tusc. 3.80: ...non naturale esse, sed voluntario iudicio et opinionis errore contractum. Brachtendorf 1997, 295.

104 Ibid., 295.

105 Ibid., 306.

106 Ibid., 300. Sed cum consentimus appetendo ea quae volumus, cupiditas, cum autem consentimus fruendo his quae volumus, laetitia vocatur. Itemque cum dissentimus ab eo quod accidere nolumus, talis voluntas metus est, cum autem dissentimus ab eo quod nolentibus accidit, talis voluntas tristitia est. Et omnino pro varietate rerum quae appetuntur atque fugiuntur, sicut allicitur vel offenditur voluntas hominis, ita in hos vel illos affectus mutatur et vertitur. (CD 14.6)

107 Ibid., 296. Brachtendorf evaluates Augustine's ideal of freedom from passions, apatheia, as being similar to the Stoics' position. 
and tranquility in the eternal life is present in Augustine's works. For example, tractatus LX (In Iohannis Euangelium tractatus) describes a state of perfection and eternal happiness. ${ }^{108}$

Furthermore, Brachtendorf mentions as significant that Augustine adopts the concept of primus motus ${ }^{109}$ from Aulus Gellius' Noctes Atticae, which reports the view of the Stoic Epictetus. Brachtendorf argues that Augustine regards primus motus as a type of passion, illustrating that Augustine does not follow the theory of either Cicero or Seneca. ${ }^{110}$ Augustine uses this doctrine extensively and mentions Gellius' report in his Quaestiones in Heptateuchum 1.30 and CD 9.4. ${ }^{111}$

In Emotion and Peace of Mind, Richard Sorabji underscores the influence of the Stoic terminology and psychology of passions on Augustine, ${ }^{112}$ such as Zeno's four emotions, eupatheia and even apatheia, particularly in Augustine's early works (On the Catholic and the Manichaean Ways of Life). ${ }^{113}$ On the other hand, the Neoplatonists also borrowed from the Stoic terminology of passions (plègai, primus motus, eupatheia, etc.) and being acquainted with their writings, Augustine might have also been indirectly influenced by the Stoics. ${ }^{114}$ Thus, these three concepts, primus motus, eupatheia and apatheia, became a significant theoretical source for Augustine. Firstly, referring to primus motus, Sorabji states that while Augustine adapts this doctrine from Stoicism, he misunderstands it. ${ }^{115}$

108 Brachtendorf argues that Augustine, similarly to Cicero, seeks the state of freedom from passions in the realm of perfection, “Augustine's reflection on Christ's passions is not an attack on Stoic moral psychology”. Brachtendorf 1997, 305.

109 Brachtendorf, Sorabji and Irwin maintain that Augustine does not receive this doctrine from Seneca (De ira 2.3.1-4), but from Gellius (19.1.14-20). Sorabji suggests that Augustine uses the text of Aulus Gellius rather than that of Seneca, which leads him to misunderstand the real Stoic position on primus motus. Sorabji 2000, 11.

110 "With the help of Gellius' report in his own interpretation Augustine employs a new conception of passion, which differs from Cicero's ideas in several respects". Brachtendorf provides three points to argue that Cicero's conception is based on the Stoic idea that a passion is a judgment of the mind; therefore primus motus as a bodily impulse should not be regarded as a passion. Augustine, however, assumes a contrary position. See Brachtendorf 1997, 299.

111 Brachtendorf 1997, 298 (n. 33).

112 Sorabji emphasises a number of these continuities and adaptations in his Emotion and Peace of Mind. For instance, in Chapter IV, "From Stoic Agitations to Christian Temptations", he uses the case of first movements to illustrate this connection. See Sorabji 2000, 341-356.

113 Sorabji maintains that in Augustine's early works, such as On the Catholic and the Manichaean Ways of Life (1.27.53-54), he stands on the Stoic point asking "who does not allow that the wise man should be free from all such miseria?" Meanwhile, in the afterlife, he insists on the Stoic eupatheiai that joy and gladness will persist. Sorabji 2000, 397-398.

114 Some Stoic terminology and psychological views on passions were selected and interpreted by Platonists, such as Zeno's four emotions, physical shocks, primus motus and eupatheia, which had an indirect influence on Augustine. Sorabji 2000, 203-204 and 65, (n. 47).

115 Sorabji believes that Augustine was misled by the report of Aulus Gellius on this Stoic 
Secondly, referring to eupatheia and apatheia, Sorabji concludes, unlike Van Riel, that Augustine uses them in a Stoic way, insisting on these psychological states in the next life and before the Fall, even though he does not believe them to be realisable in this life. ${ }^{116}$ Thirdly, Sorabji proposes that Augustine follows the Stoics in rejecting pride and lust, highlighting the function of the will. However, Sorabji also observes that Augustine has some non-Stoic views on passions, which makes his relation to the Stoics complicated. ${ }^{117}$ Despite these misunderstandings and incoherencies, Sorabji emphasises the role of adaptation and continuity in the progression from Stoic agitations to Christian temptations. I shall return to Sorabji's interpretation in the next chapter.

Unlike Van Riel and Marcia Colish, Sarah Catherine Byers regards Augustine's theory of emotions as a synthesis of Stoicism and Neoplatonism in her book entitled Perception, Sensibility, and Moral Motivation in Augustine. Byers maintains that Augustine adopts various additives (such as cognitivism and the theory of sensibility) from both Stoicism and Neoplatonism in addressing his doctrine of motivation and emotions, so that both of these schools are equally important to him. ${ }^{118}$ Byers also argues that Augustine adheres to some core Stoic and Platonic psychological principles, and that on this basis, he develops his own theory. ${ }^{119}$ Byers explains this synthesis from the viewpoint of her interpretation of propatheia, apatheia and eupatheia in Augustine: 1. Augustine adopts the Stoic view that preliminary passions (propatheiai) are impressions of the mind, and he

conception, since he had not read Seneca. Sorabji points out that it was, in fact, Seneca who established the three cases that Augustine introduces. 1. The first movement [pallor] of the Stoic philosopher in a ship; 2. The uncontrolled rise of the reproductive organs; 3. Flashing eyes and involuntary quickening breath. See Sorabji 2000, 11 and 355.

116 Based on CD 14.9-10, Sorabji writes, "Rather, it [apatheia] is to be hoped for in the next, and it was attained before the Fall...Augustine calls it by the name of one of the Stoic eupatheiai...that it is due to love (caritas)". Sorabji 2000, 398. This argument is also echoed by Peter King who does not believe Augustine to have abandoned the ideal of dispassionate passions.

117 See Sorabji 2000, 399.

118 "Which is the dominant note in Augustine's theory, Stoicism or Platonism? It is clear that the Stoicism is primary for describing the genesis of a concrete action, because an action is provoked by an impression having sayable content and consent. Nevertheless, given that the discursive part of the mind is the least excellent part, in Augustine's view, and given that the psychological underpinning, attraction for objects, is conceived of in Platonic terms, the Stoicism and Platonism are equally important... what is intriguing about this synthesis is the way that it coherently combines cognitivism and sensibility in motivation... Our recovery of Augustine's well-integrated account thus looks rather timely". Byers 2013, 53-54.

119 See the section "Augustine's adherence to core Stoic psychological principles" in Byers 2013, 60-69. 
identifies such impressions as dubitative cognitions $;{ }^{120}$ 2. Augustine advocates the Stoic ideal of apatheia and transposes it into Heaven; ${ }^{121}$ and 3. Augustine adheres to the Ciceronian and Stoic dichotomy between pathe and eupatheiai in referring to the distinction between good and bad emotions and combines the Stoic eupatheia with the Platonic-Peripatetic goodness. ${ }^{122}$ Byers thus concludes that Augustine "coherently combines cognitivism and sensibility in motivation" and "the resulting synthesis should be considered a coherent position developed from these two earlier [Stoic and Neoplatonic] schools". ${ }^{123}$

The above arguments concerning the Neoplatonic and Stoic influence on Augustine are focused predominantly on these three points pertaining to the different stages of passions: origination (primus motus), control or elimination (metriopatheia and apatheia), and the good emotional state (eupatheia). Focusing on these aspects, I will introduce some early Christian predecessors ${ }^{124}$ whose views are doctrinally relevant in this context:

(a) Clement of Alexandria. Clement follows Chrysippus' description of passions as uncontrollable or irrational impulses that are against reason (Strom. 2.13 (59.6)). He also recommends the Platonic therapy strategy of metriopatheia (using one's reason to control the epithumetikon and the thumoeides, in Strom. 2.8 (39.4)), ${ }^{125}$ adopting the Platonic partition of the soul in a way similar to Philo. As for metriopatheia and apatheia, he believes that metriopatheia as moderation therapy is the basic level that Christians should attain, but that it is difficult for them to realise apatheia. His view of apatheia (the Christian perfect state that is

120 "...the notion of a motivating impression and the syntactic forms Augustine attributes to his suggestiones are inspired by Stoicism...it is clear in the Stoic sources that preliminary passions are changes in the rational soul (animus) caused by impressions made on the mind...He [Augustine] developed the implications of Stoic cognitivism by identifying the cause of preliminary passions as doubt, meaning a dubitative sayable subsisting in an impression". Byers 2013, 45, 100 and 101.

121 "Augustine advocates a kind of passionlessness (apatheia) that is in keeping with the general definition of this state offered by the Stoics...He actually endorses the Stoic definition, saying that it is characteristic of the saints in heaven". Byers 2013, 68-69.

122 "He does not deny that the pathe-eupatheiai dichotomy is a good conceptual distinction... a good natural temperament (eupatheia) is valuable...The category relevant to the comparison with Platonic and Peripatetic ontological goodness". Byers 2013, 60, 63 and 70.

123 Byers 2013, 52-53. Byers's thesis of Augustine's close adherence to the Stoic doctrines of propatheia, apatheia and eupatheia is not quite convincing, particularly because she does not take into account the historical development of Augustine's views. I shall evaluate her view of propatheia and discuss Augustine's notion of apatheia and eupatheia in the next chapter.

${ }^{124}$ For an introduction to the relations between early Christians and the Hellenistic tradition, see H. Chadwick, Early Christian Thought and the Classical Tradition (Oxford: Clarendon Press, 1966).

${ }^{125}$ Knuuttila 2004, 117. 
connected with agape, in Strom. 6.9 (74.2)), is similar to the Stoic eupatheia, but as distinct from the Stoics, Clement states that it is associated with supernatural love. Clement's position on the bipartition of the soul (Strom. 2.21 (129.1-5)), metriopatheia (Strom. 2.8 (39.4)) and the Christian perfect state without caution, are also found in Augustine's CD 14.19 and De Trin. 10.10.13. ${ }^{126}$ Although Clement's works were not familiar to Augustine, they represent Christian eclecticism with respect to the philosophical discussions on emotions found in many authors.

(b) Origen. Origen employs the Stoic concepts of apatheia and propatheia (first movement, primus motus). He associates propatheia with the Christian conception of incipient sins and treats the former as the psychological state of freedom from passions as a preparation for the divine love (agapē) and "apathetic philanthropy" as parts of a deificatory union with God. ${ }^{127}$ In Comm. in Matth. 15.16-17, Origen points out that a virtuous man should be free from emotions such as distress, fear, pleasure, appetite and sexual desires, because they are disturbances that should be extirpated in order to attain the perfection of the soul, apatheia and theosis. ${ }^{128}$ Origen also applies the concept of $\sin$ to propatheia and maintains that the involuntary first movements are bad suggestions (in De principiis 3.1.2-4), but not considered as indicating culpability if resisted. Origen's interpretation of the origin of passions illustrates a clear Stoic influence. Origen's version of propatheia displays similarities with that of Augustine, for example, his distinction between suggestio, delectatio, and consentio (De sermone Domini in monte 12.34-5). ${ }^{129}$

\footnotetext{
${ }^{126}$ CD 14.19: Hinc est quod et illi philosophi qui veritati propius accesserunt iram atque libidinem vitiosas animi partes esse confessi sunt, eo quod turbide atque inordinate moverentur ad ea etiam quae sapientia perpetrari vetat, ac per hoc opus habere moderatrice mente atque ratione...Hae, inquam, partes in paradiso ante peccatum vitiosae non errant. Non enim contra rectam voluntatem ad aliquid movebantur unde necesse esset eas rationis tamquam frenis regentibus abstinere. De Trin.10.10.13: fruimur cogmitis, in quibus voluntas ipsis propter se ipsa delectata conquiescit.

127 "Clement and Origen did not believe that natural emotions are necessary. The Christian version of apatheia is detachment from the values which are embedded in human emotions. This is combined with a new conception of oneself without self-will based on deificatory participation in God, who is apathess and agapē". Knuuttila 2004, 127.

128 Origen refers to an example of apatheia in Comm. in Matth. 13.16, claiming that the wise can be emotionally unmoved when faced with the death of their parents. See Knuuttila 2004, 122.

129 Knuuttila 2004, 170. For Augustine's knowledge of Origen, see Joseph W. Trigg, "Origen", in Augustine through the Ages: An Encyclopedia, ed. Allan D. Fitzgerald (Michigan/Cambridge: Eerdmans, 1999), 603-605; György Heidl, Origen's Influence on the Young Augustine: A Chapter of the History of Origenism (Piscataway, NJ: Gorgias Press, 2003).
} 
(c) Cappadocian Fathers. Basil, Gregory of Nyssa and Gregory of Nazianzus, the main representatives of the Cappadocian Fathers, were influenced by Alexandrian theologians' (especially Origen's) ${ }^{130}$ and Platonic authors' doctrines of passions. The Cappadocians follow the Origenean view of the first movements toward evil as prepassions (Gregory of Nyssa, De vita Moysis 2.89-101 (60.1-64.5)). At the same time, they all agree with the theory of a tripartite soul and maintain that the irrational parts of the soul must be moderated and made obedient to reason by loving God and following the humility of Christ. Referring to metriopatheia and apatheia, the Cappadocians argue that there is a distinction between less perfect and perfect Christians (the former practicing metriopatheia and the latter representing love and apatheia). Similarly to Origen, the Cappadocians recommend an ascetic way of life to support spiritual progress and virtuous thoughts. ${ }^{131}$

(d) St Antony the Egyptian hermit. Antony (c. 250-350) is regarded as one of the founders of the Egyptian ascetic monasticism. ${ }^{132} \mathrm{He}$ considers passions to be demonic temptations and pursues an ascetic spirituality to resist the attacks. ${ }^{133}$ He suggests the use of shame to repel desires and sinful thoughts in seeking spiritual freedom and perfection. ${ }^{134}$ His story inspired Augustine's ascetic ideal through the Latin translation (by Evagrius of Antioch) of Athanasius' work, Life of Antony. ${ }^{135}$

(e) Evagrius of Pontus. Evagrius (c. 345-399) is the Father of the Egyptian desert who follows the Origenist tradition as a Greek theorist of monasticism. He develops the idea of controlling propatheia, contemplation, and apatheia under the influence of Alexandrian teachers. He introduces a scheme of eight types of

\footnotetext{
${ }^{130}$ For example, Basil and Gregory of Nazianzus collected the writings from Origen in their Philocalia. See Knuuttila 2004, 127 (n. 62).

${ }^{131}$ For the therapy of passions, see Basil's Ascetical Works (455-6), Gregory of Nazianzus' Adversus iram (PG 37, 813-51, which also borrows from Plutarch's On Freedom from Anger), Gregory of Nyssa's De vita Moysis (2.18 (38.23-5)) and De anima et resurrectione (PG 46, 61B). See Knuuttila 2004, 129-132. The question of the Cappadocian influence on Augustine is complicated, see Lewis Ayres, "The Cappadocians", in Augustine through the Ages: An Encyclopedia, ed. Allan D. Fitzgerald (Michigan/Cambridge: Eerdmans, 1999), 121-124.

132 Another coetaneous leader is said to be Pachomius (292-346). For Antony and the Egyptian monastic movement, see Knuuttila 2004, 136-139.

133 Knuuttila 2004, 139.

134 Athanasius, Life of Antony 55 (PG 26, 835-976). See Sorabji 2000, 220 and Knuuttila 2004, 138-139.

135 See Conf. 8.6.13-15 and Chadwick 1991, 143 (n. 11). Cf. Knuuttila 2004, 139 (n. 97).
} 
disturbing thoughts (logismoi) that one should expel as first movements: gluttony (gastrimargia), fornication (porneia), avarice (philarguria), distress (lupē), anger (orgē), depression (akēdia), vainglory (kenodoxia), and pride (huperēphania). ${ }^{136}$ These are evil thoughts and temptations (peirasmoi) that move the emotional part of the soul and obscure the rational part. ${ }^{137}$ In order to conquer these incipient passions, one should live ascetically and expel evil thoughts by thinking of something else-this is the standard tool for learning self-control. Evagrius employs the Origenist conception of apatheia as the pursuit of freedom from incipient and other passions. His model for monastic life is divided into three elements, praktikē, physike and theologia. ${ }^{138}$ From praktike (fighting against the first movements) one should proceed to physike and theologia (contemplating natural order and divine nature respectively). Evagrius presents a ladder comprising of a psychological and therapeutic process, and establishes a relation between apatheia, the contemplation of God, and theosis. ${ }^{139}$ This contemplative, apathetic method (Practical Treatise 49, 56, 78) is also mentioned in Augustine's $C D$ 19.19, ${ }^{140}$ even though Augustine was not familiar with Evagrius' works.

(f) Jerome. Jerome distinguishes prepassion (propatheia, propassio) from passion (pathos, passio) on the basis of whether assent (consentire) or judgment (iudicium) is involved. ${ }^{141}$ An evil prepassion is the first stimulus of thought (cogitatio) that tends to proceed into an evil passion, which involves assent and is a sin (vitium). Prepassions should not be condemned even though they may potentially be harmful. Indeed, even Christ was assailed by involuntary stimuli. However, he did not allow emotion to dominate his mind. ${ }^{142}$ Jerome claims that Christ was beginning to be sad because of prepassions, distinguishing between the

136 Evagrius Practical Treatise ch. 6. See Sorabji 2000, 358 and Knuuttila 2004, 141.

137 "For a monk temptation (peirasmos) is a thought rising through the emotional part (to pathetikon) of the soul and darkening the intellect. For a monk sin (hamartia) is assent (sunkatathesis) to the forbidden pleasure of the thought". (Evagrius Practical Treatise 74-75). See Sorabji 2000, 360.

138 For Evagrius' view of apatheia, see Mette Sophia Bocher Rasmussen, "Like a Rock or like God? The Concept of apatheia in the Monastic Theology of Evagrius of Pontus", in Studia Theologica 59 (2005), 147-162. Cf. Knuuttila 2004, 140-144.

139 Rasmussen 2005, 150-152 and Knuuttila 2004, 140-142.

${ }^{140}$ CD 19.19: Nec sic esse quisque debet otiosus ut in eodem otio utilitatem non cogitet proximi, nec sic actuosus ut contemplationem non requirat Dei. In otio non iners vacation delectare debet, sed aut inquisitio aut inventio veritatis, ut in ea quisque proficiat et quod invenerit ne alteri invideat.

141 See Sorabji 2000, 352-353.

142 Sorabji 2000, 353. 
condition of "being sad (a case of passiones)" and "beginning to be sad (a case of propatheiai)". ${ }^{143}$ Furthermore, Jerome attacks Evagrius and Origenism on the issue of apatheia. He maintains that apatheia is impossible to attain in this life; if humans could indeed achieve a state apatheia or imperturbability, they would either be a rock or a God. ${ }^{144}$ This criticism is also found in Augustine. ${ }^{145}$

(g) Ambrose. Ambrose follows the tradition of controlling one's passions by the faculty of reason. He hierarchically designates passions into two categories: avarice, pride, ambition, envy, and strife refer to the soul, whereas luxury and gluttony pertain to the body. ${ }^{146}$ In his De officiis, Ambrose cautions that any mundane movement of the soul should be avoided and that one must remain alert like a good watchman (bonus speculator). ${ }^{147}$ One should control one's passions by avoiding whatever might give rise to sudden impulses averse to the control of reason, and eradicate these impulses at an early stage; otherwise, once the mind is assailed, these impulses will become increasingly unchecked and harmful. ${ }^{148}$ This precaution and control of one's mind also maintains the constancy and purity of one's heart. ${ }^{149}$ Thus, in the coming world, there will be peaceful perfection in the

143 "There is this difference between pathos and propatheia, that is between passion (passio) and pre-passion (propassio): passion is counted as a sin (vitium); pre-passion, though it involves the fault (culpa) of something beginning, is not treated as a matter for accusation (in crimine)... But if he once assents, and makes a thought (cogitatio) into an emotion (affectus)... he has passed from pre-passion to passion". Sorabji 2000, 354.

144 Jerome's Letter 133 to Ctesiphon (CSEL 56. 246): "Evagrius Ponticus of Ibora, who writes to the virgins, writes to the monks, writes to that woman whose name of blackness attests the shades of faithlessness, published a book and sentences On Apatheia, which we can call impassibility or imperturbability, when the mind is never disturbed by any thought or vice, and is, to put it plainly, either a rock or a God". Sorabji 2000, 397. For the relationship between Jerome and Augustine, see Carolinne White, The Correspondence (394-419) between Jerome and Augustine of Hippo (Lewiston, NY: Edwin Mellen Press, 1990).

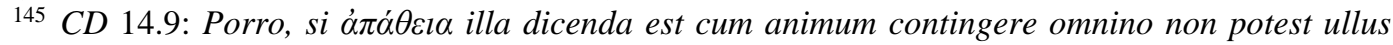
affectus, quis hunc stuporem non omnibus vitiis iudicet esse peiorem?... Si autem ḋ $\dot{\alpha} \theta \varepsilon i \alpha$ illa est ubi nec metus ullus exterret nec angit dolor, aversanda est in hac vita si recte, hoc est secundum Deum, vivere volumus.

146 Colish 1985 (II), 55-56.

147 Ambrose De officiis 1.47.228: Caveat etiam motus animi sui: ipse enim sibi et observandus et circumspiciendus est et, ut adversum se cavendus, ita etiam de se tuendus. Sunt enim motus in quibus est appetitus ille qui quasi quodam prorumpit impetu... Unde boni speculatoris est ita praetendere animo ut appetitus neque praecurrat rationem neque deserat, ne praecurrendo perturbet atque excludat, eam deserendo destituat. Ivor J. Davidson (transl. and ed.), Ambrose: De officiis (New York: Oxford University Press, 2001), 248-251.

${ }^{148}$ De officiis 1.47.229: Perturbata enim mente latius se ac longius fundit appetitus et tamquam efferato impetu frenos rationis non suscipit nec ulla sentit aurigae moderamina quibus possit reflecti.

${ }^{149}$ De officiis 1.47.229-230: Perturbatio tollit constantiam, destitutio prodit ignauiam, accusat pigritiam ...consiliis sola potest auctoritatem suam atque illud quod deceat tenere, constantia. 
vision of God. ${ }^{150}$ This eclectic, Christianised, Stoic-Platonic position had a direct influence on Augustine, ${ }^{151}$ who also sought a tranquil and contemplative life in this earthly city and the perfect apatheia without sin in the future City of God. ${ }^{152}$

Even though these early Christian Fathers suggest various ways of combining philosophical and Christian ideas, certain themes are recurrent: 1 . The Fathers share the Platonic idea of the bipartition of the soul, arguing that the lower part should be submissive to reason; 2. The first movement (primus motus, impetus) is the beginning of passion and often an evil suggestion, which is a sign of humanity's weakness following the Fall; ${ }^{153} 3$. Freeing oneself from one's passions (apatheia) or being able to strictly control them prepares one for a close relationship with God; 4 . The relationship between the rational and the emotional part of the soul was believed to be different in paradise, in the present life and in Heaven. These early Christian Fathers were influenced by Platonic and Stoic traditions and, as a consequence, their Christian doctrines of passions continue to reflect the eclectic influence of these two traditions.

As he discusses philosophical opinions, Augustine states in $C D$ 9.4: "the Stoics, disagree with the Platonists and Peripatetics verbally rather than essentially". ${ }^{154}$ From Augustine's point of view, there are no radical differences

${ }^{150}$ De officiis 1.48.239: Hic ergo in imagine ambulamus, in imagine videmus; illic facie ad faciem, ubi plena perfectio, quia perfectio omnis in veritate est.

151 In his early works (approximately between the years 386 and 392), such as De musica (6.16.51-55), De moribus ecclesiae catholicae (1.27.53-54), De ordine (2.6.18), and Contra Academicos (1.4.11) among others, Augustine understands impassibility as a psychological state avoiding the perturbations of emotions (occasionally even good emotions such as compassions) and fixing one's attention on God, attaining the harmonious tranquility of mind and fostering the four virtues of prudence, temperance, fortitude, and justice. This account, Colish notes, is influenced by Ambrose's view of apatheia. "He [Augustine] begins to explore the positive answer to this question, recasting it in Christian terms, as early as his De moribus, in a series of observations paralleling Ambrose's view that apatheia is desirable and possible for the Christian, but only with the help of God's grace". Colish 1985 (II), 222.

152 Augustine shows his reluctance towards yielding to passions in this life. CD 14.9: Proinde, quod fatendum est, etiam cum rectas et secundum Deum habemus has affectiones, huius vitae sunt, non illius quam futuram speramus, et saepe illis etiam inviti cedimus.

153 These Christian Fathers (that is, Ambrose, Clement Alexandria, Origen, Cappadocian Fathers) share the view that before the Fall, the emotions of Adam and Eve were completely controlled by their reason and that they operated only when their will allowed them to, in a happy and harmonious state; however, after the Fall, Adam and Eve were condemned to concupiscence and death, their will weakened so that they were unable to fully control their emotions. In this sense, a first movement or involuntary passion as a sort of uncontrollable state is a sign of the original sin. For the relations between original sin and emotions, see J.N.D Kelly, Early Christian Doctrines (5th ed.) (London: A \& C Black, 1977), 353-366; 508.

${ }^{154}$ CD 9.4: Hos autem, id est Stoicos, Cicero in libris de finibus bonorum et malorum verbis magis quam rebus adversus Platonicos seu Peripateticos certare convincit. Cf. Cicero, Defini. Books 3 
between these schools on the issue of passions. He makes the following observations:

For I consider that, as far as the pith of the matter is concerned, rather than the mere sound of words, the view which the Stoics hold is not different from that of the Platonists and Peripatetics...In view of these things, then, there is no difference, or almost none, between the opinion of the Stoics and that of the other philosophers concerning the passions and disturbances of the mind. ${ }^{155}$

After these remarks, Augustine further explains:

...for both sides maintain that the mind and reason of the wise man are not under the dominion of the passions... The mind in which this belief is firmly established, then, permits no disturbances to prevail in it contrary to reason, even though these assail the baser parts of the soul. On the contrary, the mind itself is master of all such disturbances, and, by withholding its consent from them and resisting them, exercises a reign of virtue. ${ }^{156}$

Thus, Augustine argues that both the Stoics and the Platonic-Peripatetics highlight the function of intellectual acts and the serenity of a mind that is not dominated by passions.

Augustine was well aware of the differences between these two doctrines of passions, and his philosophical considerations pertaining to passions were largely derived from them. However, he criticises both doctrines and shifts the discussion to theological matters, applying the concepts of will (voluntas), love (amor), sin (peccatum), justice (iustitia), and redemption (redemptio) in CD 9.5, where he comments on the three stages of passions (origination, control, and emotional state): (1) The first stage is a movement of the soul and the beginning of a passion. This involuntary movement frequently takes place in the soul and is regarded as a sign of the original sin when directed towards illicit things. Even then, however, it is not considered to be a sin if it is repelled as soon as possible. Yet, Augustine also mentions compassion (compassio) as a type of first

and 4.

155 CD 9.4: Nam et ipsos nihil hinc aliud quam Platonicos et Peripateticos sentire existimo, quantum ad vim rerum adtinet, non ad vocabulorum sonum...Quae si ita sunt, aut nihil aut paene nihil distat inter Stoicorum aliorumque philosophorum opinionem de passionibus et perturbationibus animorum.

${ }^{156}$ CD 9.4: Utrique enim mentem rationemque sapientis ab earum dominatione defendunt...Ita mens ubi fixa est ista sententia nullas perturbationes, etiamsi accidunt inferioribus animi partibus, in se contra rationem praevalere permittit: quin immo eis ipsa dominatur eisque non consentiendo et potius resistendo regnum virtutis exercet. 
movement that is good, since compassion is just and free from all vice. ${ }^{157} \mathrm{He}$ cites this example to criticise the Stoic view that all passions are evil and cannot move the soul of the wise. ${ }^{158}$ (2) God governs and helps the mind that controls or moderates passions in the service of righteousness. ${ }^{159}$ Passions therefore represent a type of weakness and cannot be avoided in this life. However, if we maintain a good will and love in a godly manner, our passions will be right. ${ }^{160}$ Moreover, some emotions may be regarded as good in themselves, for example, the delight of truth, friendship, and pity, as Augustine states in Confessiones 1.20.31. ${ }^{161}$

Freedom from passions is an ideal to Augustine, who believes that God and good angels are not disturbed by any emotions. ${ }^{162}$ After the redemption, the redeemed people will assume the place left by fallen angels in the City of God and enjoy God's presence. ${ }^{163}$ Enjoying the everlasting good (bona), joy (gaudium) and love

157 Augustine does not use the term primus motus (first movement), but rather expressions such as
"a kind of fellow feeling in our hearts... which compels us" (alienae miseriae quaedam in nostro
corde...compellimur) and "impulse" (motus) to refer to compassion as a first movement and a
passion which should not be condemned, as shown in CD 9.5: Quid est autem misericordia nisi
alienae miseriae quaedam in nostro corde compassio qua utique si possumus subvenire
compellimur? Servit autem motus iste rationi quando ita praebetur misericordia ut iustitia
conservetur, sive cum indigenti tribuitur, sive cum ignoscitur paenitenti. Hanc Cicero locutor
egregius non dubitavit appellare virtutem, quam Stoicos inter vitia numerare non pudet, qui tamen,
ut docuit liber Epicteti, nobilissimi Stoici, ex decretis Zenonis et Chrysippi, qui huius sectae primas
habuerunt, huiusce modi passiones in animum sapientis admittunt quem vitiis omnibus liberum
volunt. 158 Augustine argues that compassion as a type of first movement is better than the fear of shipwreck that the Stoics feel. CD 9.5: Nam et misericordiam Stoicorum est solere culpare; sed quanto honestius ille Stoicus misericordia perturbaretur hominis liberandi quam timore naufragii.

${ }^{159}$ CD 9.5: Deo quippe illa ipsam mentem subicit regendam et iuvandam mentique passiones ita moderandas atque frenandas ut in usum iustitiae convertantur.

${ }^{160}$ CD 9.5: Sed adhuc merito quaeri potest utrum ad vitae praesentis pertineat infirmitatem etiam in quibusque bonis officiis huiusce modi perpeti affectus. In CD 14.9, Augustine argues that the passions of the citizens of the holy City of God can be virtuous and praiseworthy: Hi motus, hi affectus de amore boni et de sancta caritate venientes si vitia vocanda sunt, sinamus ut ea quae vere vitia sunt virtutes vocentur...Habemus ergo eas ex humanae condicionis infirmitas; non autem ita Dominus Iesus, cuius et infirmitas fuit ex potestate.

161 Conf. 1.20.31:...custodiebam interiore sensu integritatem sensuum meorum, inque ipsis parvis parvarumque rerum cogitationibus veritate delectabar. Falli nolebam, memoria vigebam, locutione instruebar, amicitia mulcebar, fugiebam dolorem, abiectionem, ignorantiam. Quid in tali animante non mirabile atque laudabile? At ista omnia dei mei dona sunt. ("An inward instinct told me to take care of the integrity of my senses, and even in my little thoughts about little matters I took delight in the truth. I hated to be deceived, I developed a good memory, I acquired the armoury of being skilled with words, friendship softened me, I avoided pain, despondency, ignorance. In such a person what was not worthy of admiration and praise? But every one of these qualities are gifts of my God".) ${ }^{162}$ CD 9.5: Sancti vero angeli et sine ira puniant quos accipiunt aeterna Dei lege puniendos, et miseris sine miseriae compassione subveniant, et periclitantibus eis quos diligunt, sine timore opitulentur; et tamen istarum nomina passionum consuetudine locutionis humanae etiam in eos usurpentur propter quandam operum similitudinem, non propter affectionum infirmitatem, sicut ipse Deus secundum scipturas irascitur, nec tamen ulla passione turbatur.

${ }^{163}$ CD 22.1: Qui de mortali progenie merito iusteque damnata tantum populum gratia sua colligit 
(amor), is the spiritual state of the elected when they see and praise God in the Heavenly City. ${ }^{164}$ This spiritual fulfilment includes the perfection of the human image of God in the vision of God, the feeling of contentment with nothing lacking, and redemption from all evil.

Comparing Augustine's understanding of the different stages of passions to those of Neoplatonic and Stoic doctrines, we may observe that the latter two sources are more similar than Augustine's views in many places, and that Augustine modifies many of the ideas that he receives from them. Christian conceptions of passions form another source, but they are also essentially influenced by Neoplatonism and Stoicism, their only original contribution being a reference to supranatural grace. Augustine does not simply settle for following any of these predecessors, even though their thoughts did influence him in various ways. As we proceed to discuss the issue of controlling and moderating passions, we will see how Augustine receives and transforms the traditional approaches familiar to him.

ut inde suppleat et instauret partem quae lapsa est angelorum.

164 CD 22.30: Erit ergo illius civitatis et una in omnibus et inseparabilis in singulis voluntas libera, ab omni malo liberata et impleta omni bono, fruens indeficienter aeternorum iucunditate gaudiorum, oblita culparum, oblita poenarum...Ibi vacabimus et videbimus, videbimus et amabimus, amabimus et laudabimus... 



\title{
CHAPTER THREE: CONTROL AND MODERATION OF PASSIONS
}

\begin{abstract}
Nam et misericordiam Stoicorum est solere culpare; sed quanto honestius ille Stoicus misericordia perturbaretur hominis liberandi quam timore naufragii...Servit autem motus iste rationi quando ita praebetur misericordia ut iustitia conservetur, sive cum indigenti tribuitur, sive cum ignoscitur paenitenti. (CD 9.5)
\end{abstract}

Deo quippe illa ipsam mentem subicit regendam et iuvandam mentique passiones ita moderandas atque frenandas ut in usum iustitiae convertantur. (CD 9.5)

Hos autem, id est Stoicos, Cicero in libris de finibus bonorum et malorum verbis magis quam rebus adversus Platonicos seu Peripateticos certare convincit. (CD 9.4)

This chapter examines how Augustine transforms his predecessors' conception of the therapy of passions into his own theory, with particular focus on whether Augustine misinterprets his predecessor's doctrines in his approach. As mentioned previously, during his early years, Augustine was influenced by Stoicism and Neoplatonism and he often pondered whether passions were indeed evil and how to address them. ${ }^{1}$ After the mid-390s, Augustine presented his views in a series of middle period writings (around 395-410) and later codified his mature understanding in De civitate Dei (413-427). When discussing Augustine's position in these writings, some scholars maintain that Augustine misunderstands the Stoics, whereas some others argue that he grasps their works rather well and his accounts are consistent with Stoic teaching. These discussions mainly concern four concepts: propatheia (propassio or primus motus), ${ }^{2}$ metriopatheia, apatheia and eupatheia. I shall examine these concepts in the following sections from the perspective of whether Augustine's interpretation of these reflects some misunderstanding of the Stoic position. In section one, I shall compare Augustine's opinions in his early, middle and late writings to determine whether changes occur in his interpretation of the doctrine of propatheia. In section two, I shall focus on Augustine's comments

\footnotetext{
${ }^{1}$ Augustine accepted the Stoic ideas of passions in his early years and blamed himself for his uncontrollable emotions on the death of his mother, Monica. In conf. 9.12, he asks, "did I blame the weakness of my passion, and refrain my flood of grieving?" (increpabam mollitiam affectus mei, et constringebam fluxum maeroris, cedebatque mini paululum). At last, Augustine "has offended" (weeping) in bewailing his mother for some time (flevisse me matrem exigua parte horae).

${ }^{2}$ Different writers use various terms to express the concept of involuntary prepassions, not only in Augustine's era, but also among contemporary commentators. While propassio, propatheia and primus motus were common usages, Augustine did not adopt them, preferring expressions such as suggestio (De sermone Domini in monte 12.34-5), passio praeveniens mentis (CD 9.4-5) or perturbatio (Quaestiones in Heptateuchum 1.30). Commentators today also use various terms such as "preliminary passions", "first movements", "prepassions", "pre-emotions", "preliminary reactions" and "preliminary impulses".
} 
on the relationship between apatheia and metriopatheia and examine how they compare to the Stoic position. In section three, I shall inquire as to whether or not indifference is a connotation of the Stoic concept of eupatheia and further analyse whether Augustine's equating of eupatheia with ordinary passions and interpreting the Stoic ideal of eupatheia as stupor are based on his misunderstandings. Next, section four contains a survey of Augustine's new scheme of the therapy of passions to determine if his theology has deviated from philosophical traditions. Section five provides the main line of Augustine's view of the will and passions and then proceeds to theological discussions in Chapters 4 and 5. Focusing on these conceptions and discussions, I shall argue that Augustine is familiar with the Stoic doctrine, but in his later works, he deliberately deviates from some of their concepts (such as propatheia and eupatheia). I shall also demonstrate that Augustine deviates in order to refute their "pride" and to defend his Christian position on the psychology of passions. On the basis of this background, Augustine makes the bold observation that no substantial distinctions exist between apatheia and metriopatheia in the Stoic and Peripatetic contexts and suggests that the dispute between them on these terms is of no consequence. In short, I shall propose that these deliberate new uses of terms by Augustine do not derive from a misunderstanding, but rather follow from his attempt during his late theological thinking at constructing his own means of dealing with passions.

\subsection{Disputation on Augustine's Misunderstanding of Propatheia}

Some researchers contend that Augustine misunderstands the Stoic conception of propatheia (first movement or preliminary passion) because he incorrectly assumes that propatheia is a passion in the Stoics. In contrast, other scholars insist that Augustine's interpretation is in line with the doctrine of the Stoics, arguing that propatheia is merely an involuntary impulse or a first movement of the soul before the assent of reason that is required for passion. By discussing the arguments of Sorabji and Sarah Byers, I shall explain these two different positions.

Sorabji argues that in reading Aulus Gellius' report of the Stoic position in Noctes Atticae, which is elaborated on in CD 9.4 and Quaestiones in Heptateuchum 1.30, Augustine misinterprets the Stoics' conception of primus 
motus and mistakenly claims that the Stoic philosophers actually accept that they are agitated by the involuntary first movement. ${ }^{3}$ Sorabji suggests that Augustine's misinterpretation is due the following factors:

(1) Augustine does not adopt Seneca's account of the first movement; ${ }^{4}$ Augustine's main textual source of the first movement is Aulus Gellius. Augustine is misled by Gellius' use of the verb jitter (pavescere) in explicating the verb pale (pallescere). ${ }^{5}$ This minute literary change leads Augustine to the incorrect interpretation that the Stoics cannot avoid the sudden agitation of fear.

(2) The Latin translation of Origen transforms the Stoic first movements into bad thoughts and sins and this serves as the main doctrinal source for Augustine. According to Sorabji, Augustine's approach is not in line with Seneca's thinking that first movements are distinct from emotions because Augustine is not familiar with Seneca's account of this point. ${ }^{6}$ This is an important factor that transforms Augustine's understanding into something closer to Origen's interpretation that has obscured the distinction between involuntary first movements and willed emotion. ${ }^{7}$

(3) To Augustine, it is impossible to avoid emotion. He connects the involuntary first movement with original sin, which attests to his traditional Christian standpoint on the issue of first movements. ${ }^{8}$

\footnotetext{
3 "He [Augustine] cites the Stoics' acceptance of first movements as if it proved that they really accepted emotion itself". Sorabji 2000, 10. Sorabji usually uses the term "first movement" (primus motus) to refer to propatheia in his works.

${ }^{4}$ After a discussion of Seneca's three cases of first movement, which Augustine also coincidently discusses, Sorabji states that Augustine did not actually read Seneca's account of it. "If Augustine had read Seneca, instead of Aulus Gellius, would he have seen that he did not here have a sufficient reason to downgrade lust in comparison with anger?" Sorabji 2000, 11.

5 'I shall argue that Augustine is partly misled by Gellius' change of the letters ' $l l$ ' to ' $v$ '. The Stoic is allowed to grow pale (pallescere), but Gellius adds that he is allowed to have the jitters (pavescere), a nice literary word which hovers ambiguously between merely trembling and having real fear". Sorabji 2000, 10. He maintains that Gellius' mistaken paraphrasis of pallescere in pavescere changes the conception of merely physical movement into a psychological term that misled Augustine's judgments. Ibid., 375-384.

6 "Augustine has not noticed Seneca's point that involuntary first movements are common to all the emotions". Sorabji 2000, 11.

7 "Why is Augustine so blind to the Stoic distinction between involuntary first movements and willed emotion? There is more than one reason. First, by turning first movements into thoughts and suggestions, Origen obscured the distinction between them and emotions, which the Stoics saw as thoughts. Consequently, the description of first movements as the preliminaries (principia) of emotion, which had left the distinction quite clear in Seneca, leaves it unclear in Origen and subsequent Church Fathers". Sorabji 2000, 382. A similar argument is also emphasized in his Introduction part (Ibid., 8). For Origen's influence on Augustine, see note 129 in Chapter 2 above. 8 "Augustine connects our inability to avoid fear and grief with original sin". Sorabji 2000, 166.
} 
(4) Augustine accepts the Platonic position on the bipartition of the soul that claims that an involuntary emotion is the movement of the irrational part of the soul before the assent of intellect. Nonetheless, the Stoics suppose that emotion is only a type of judgment. Augustine defends the Platonic notion of the soul, which is the psychological reason for his misinterpretation of the Stoic doctrine. ${ }^{9}$

(5) Augustine's objective is to defend the Platonic moderate therapy of passions. ${ }^{10}$ This is yet a further reason to refute the Stoic doctrine of either eradicating or avoiding passions. Augustine is of the opinion that the Stoics could not resist first movements, but he misinterprets the Stoic supposition that a first movement cannot be a passion because no reason is involved. This means that Augustine's discussion of whether the Stoics could avoid sudden "passions" is meaningless, because he has already misrepresented the Stoic first movement as a passion. ${ }^{11}$

Peter King agrees with the above-mentioned argument and reasons that Augustine mistakenly interprets the Stoic propatheia as a passion. King reiterates Sorabji's account that Augustine's source is a second-hand anecdote from Gellius who has paraphrased Epictetus. ${ }^{12}$ Moreover, King states that the deeper reason for Augustine's misunderstanding of the Stoic position is that he was influenced by the Biblical teachings and was impressed by Jesus's passions (first movements); as a consequence, Augustine was dissatisfied with the Stoic position of extirpating some good prepassions, such as the emotion of mercy. ${ }^{13}$

Contrary to Richard Sorabji and Peter King, Sarah Byers proposes that both the Stoics and Augustine argue that although passions are judgments of the mind, a first movement is not a passion and is therefore not a sin. In her article "Augustine

\footnotetext{
9 "He [Augustine] is steeped in a Platonic view of the soul, which, in contrast with the Stoic view, holds that emotion is the product of irrational forces in the soul and does not have to await the assent of reason, as the Stoics suppose". Ibid., 10.

10 "In defending moderate emotion, he cites the Stoics' acceptance of first movements as if it proved that they really accepted emotion itself". Ibid., 10.

${ }^{11}$ Sorabji maintains that the Stoics certainly admit that they could experience first movements, but they do not consider them to be passions. Augustine's claim that the Stoics could not resist such "passions" is based on his misunderstanding that a first movement is a passion in the Stoic doctrine. Ibid., 10.

12 "Augustine takes the anecdote from Aulus Gellius, noct. 19.1, paraphrasing Epictetus; Augustine cites it again in hept.1.30 to prove the same point. But Augustine is mistaken. The original anecdote seems to have concerned not the passions but the 'prepassions' and to have been garbled by Gellius in transmission”. King 2012a, 17 (n. 26).

${ }^{13}$ See King 2012a, 17-18.
} 
and the Cognitive Cause of Stoic 'Preliminary Passions' (Propatheiai)", ${ }^{14}$ Byers emphasises that Augustine does not misinterpret the Stoics and that his interpretation is in accordance with the Stoic tenet. Byers cites the episode of Aulus Gellius' Noctes Atticae in $C D 9.4$ and also examines passages from Augustine's sermons (spanning twenty-seven years from 392 AD). She notes that Augustine's descriptions of preliminary passions (such as preliminary forms of jealousy, cupidity, anger, fear and some metaphor cases: a foot slipping, an irritated eye, and a speck in the eye) are consistent with the thinking of Seneca and the Stoics. ${ }^{15}$ They all contend that propatheia is merely a preparation period of passion without the mind's relevant judgment. Thus, this preliminary movement is by no means a passion. Byers offers the following supporting evidence, which is in sharp contrast to the accounts by both Sorabji and King:

(a) Augustine was familiar with the interpretations of Seneca and Gellius, and this explains his familiarity with the cognitive component of passions. ${ }^{16}$ Seneca claims that preliminary reactions are merely impressions (species, opinio) without the involvement of reason. ${ }^{17}$ Gellius also uses phantasiai and visa to describe this preliminary impression in his similar interpretation, which is found in Noctes Atticae 19.1.15-2 $1^{18}$. Byers states that Augustine was familiar with the Stoic

\footnotetext{
14 This article is echoed in the chapter of "Preliminary Passions" in Byers 2013, 100-126.

15 Byers 2003, 437, 438 and 441; Byers 2013, 102, 103 and 106.

16 "What evidence do we have that Augustine knew and was influenced by these (Seneca's) accounts of preliminary passions? Although he does not mention Seneca by name when he directly addresses the topic of affectivity, he indicates that he had more than average knowledge of Seneca in the Confessiones...he makes use of the same metaphors and identifies the same causes of anger as Seneca does". Byers 2003, 436; Byers 2013, 102.

${ }^{17}$ Seneca, De ira 2.1.4: Nobis placet nihil illam per se audere sed animo adprobante; nam speciem capere acceptae iniuriae et ultionem eius concupiscere et utrumque coniungere, nec laedi se debuisse et vindicari debere, non est eius impetus qui sine voluntate nostra concitatur. De ira 2.3.5: Ergo prima illa agitatio animi quam species iniuriae incussit non magis ira est quam ipsa iniuriae species; ille sequens impetus, qui speciem iniuriae non tantum accepit sed adprobavit, ira est, concitatio animi ad ultionem voluntate et iudicio pergentis. Numquam dubium est quin timor fugam habeat, ira impetum. vide ergo an putes aliquid sine adsensu mentis aut peti posse aut caveri. "In Seneca we find the claim that preliminaries to anger are caused by the reception of an impression (species, opinio) that one has been injured, without approval or acceptance (adprobare, capere) of the impression as true". Byers 2003, 436; Byers 2013, 102.

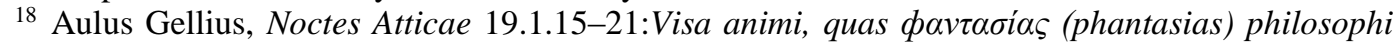
appellant, quibus mens hominis prima statim specie accidentis ad animum rei pellitur, non voluntatis sunt neque arbitraria, sed vi quadam sua inferunt sese hominibus noscitanda...et in eo tamen brevi motu naturali magis infirmitati cedamus, quam quod esse ea, qualia visa sunt, censeamus. Margaret Graver also maintains that Seneca, Epictetus, Gellius and Cicero have nearly the same accounts on propatheiai in their works (e.g., De ira 2.1-4, Noctes Atticae 19.1, Tusculanae disputationes 3.83). M. Graver, "Philo of Alexandria and the Origins of the Stoic propatheiai", Phronesis (44:4, 1999), 301 (This article also appears in Philo of Alexandria and Post-Aristotelian 
position of Seneca, as Augustine mentions Seneca once in Confessiones 5.6.11 and three times in De civitate Dei (CD 5.8 and $C D$ 6.10). ${ }^{19}$

(b) Augustine follows Seneca in making a distinction between the soul (animus) and reason (mens) to distinguish preliminary passions from passions. ${ }^{20}$ They both argue that emotions involve a judgment of reason (mens), but preliminary passions occur in the soul (animus) rather than in reason (mens). Thus, the involuntary movements of the soul without the assent of reason cannot be considered as passions.

(c) Augustine does not regard preliminary passions as sins. Byers argues that in an early sermon, Augustine describes preliminary passions as wavering reactions toward impressions, which reflects a person's momentary weakness rather than a sin. ${ }^{21}$ Byers argues that this notion of Augustine (also in $C D 14.12$ and 14.15) is consistent with Seneca's De ira 1.16.7 and Cicero's Tusc. 3.83. ${ }^{22}$

(d) Augustine holds that preliminary passions involve a doubt, waiting for the mind's judgments to decide whether this involuntary process is in accordance with the value of eternal good. ${ }^{23}$ Byers contends that Augustine makes a special contribution to the concept of propatheia in referring the preliminary passions to an uncertainty and state of doubt with a lack of confidence in God. ${ }^{24}$

From the above arguments, it is evident that all these commentators underline the importance of the reference to Gellius' Noctes Atticae in $C D$ 9.4, but they nevertheless draw opposite conclusions. In order to clarify whether Augustine makes the incorrect claim that the Stoics "really" accept the first movements as

Philosophy, ed. Francesca Alesse (Leiden·Boston: Brill, 2008), 197-222).

19 Byers 2003, 436; Byers 2013, 61 (n. 22).

${ }^{20}$ Byers points out that the mens-animus distinction is presented in Seneca's De ira 1.16.7; 2.2.2; 2.3.5; 2.4.2, Gellius' Noctes Atticae 19.1.17-18 and Augustine's CD 9.4-5, which illustrates their inner connections. "Since Seneca regularly attributes superficial changes and preliminary passions to the animus, but judgment that constitutes a passion to the mens...Augustine is in line with his Stoic sources when he invokes a mens-animus distinction”. Byers 2003, 437-438; Byers 2013, 104. 21 "Reflecting on those accounts of preliminary passions with which he [Augustine] was familiar, he argues that a reflex reaction of panic fear to a surprise event cannot be explained except as a wavering in (though not a loss of) the virtue of the impressed person, which must be due to a momentary weakness in said person's apprehension of the truth ("light")". Byers 2003, 438; Byers 2013, 104-105. I think that the reference Byers has in mind is not a sermon, but En. Ps. 37.15.

22 "...he [Augustine] denies that preliminary passions are sins. Augustine thinks they are evidence of a damaged, weakened state of soul". Byers 2003, 438 (n. 37); Byers 2013, 104 and 111 (n. 73).

23 "Augustine said that a passion is caused by a false judgment that a temporal good has the value of the eternal goods. And he held that in a preliminary passion, one doubts whether a particular temporal good has the value of eternal goods". See Byers 2003, 440; Byers 2013, 108.

${ }^{24}$ Byers 2003, 442-444; Byers 2013, 104-110. 
passions, I shall return to the original texts and compare Augustine's report and Gellius' own text to determine Augustine's statement and his actual attitude:

In eo libro se legisse dicit A. Gellius hoc Stoicis placuisse, quod animi visa, quas appellant phantasias nec in potestate est utrum et quando incidant animo, cum veniunt ex terribilibus et formidabilibus rebus, necesse est etiam sapientis animum moveant, ita ut paulisper vel pavescat metu, vel tristitia contrahatur, tamquam his passionibus praevenientibus mentis et rationis officium; nec ideo tamen in mente fieri opinionem mali, nec adprobari ista eisque consentiri. Hoc enim esse volunt in potestate idque interesse censent inter animum sapientis et stulti, quod stulti animus eisdem passionibus cedit atque adcommodat mentis adsensum; sapientis autem, quamvis eas necessitate patiatur, retinet tamen de his, quae adpetere vel fugere rationabiliter debet, veram et stabilem inconcussa mente sententiam..$^{25}$ (CD 9.4)

This paragraph contains a slight change that appears rather strange: Augustine first presents the Stoic concept of first movements as experiences of certain "mental images" (animi visa, which they call phantasias), and these phantasias as well as the movements they cause are beyond our control. Referring to Gellius having read "in eo libro" that "necesse est etiam sapientis animum moveant" (they of necessity move even the wise man's soul), Augustine's interpretation of the Stoic proposition is rather exact. Nonetheless, Augustine's next paraphrasing appears to be different, since he uses the words "his passionibus" (these passions) to replace the previous "animi visa", and states, "these passions running ahead of the function of the mind and reason" (tamquam his passionibus praevenientibus mentis et rationis officium). Thus, the Stoic "mental images" that occur before the judgements of mind become "passions" in Augustine. However, using passiones in this manner is obviously not

25 "Aulus Gellius says that, in this book, he read that the Stoics believe that the soul experiences certain mental images, which they call phantasiae, and that it is not in our power to determine whether and when these shall strike the soul. When these images come about as a result of terrifying and awesome things, they of necessity move the soul even of the wise man. Thus, he grows pale with fear for a little while, or he is oppressed by sadness, these passions running ahead (passionibus praevenientibus) of the function of the mind and reason; but it does not follow that a belief that there is something bad will arise in the mind, or that the mind will accept (adprobare) them and consent (consentiri) to them. For such consent, they hold, is within our power; and the difference between the mind of a wise man and that of a fool is that the fool's mind yields to these same passions and adapts itself to them, whereas the wise man, though he experiences them of necessity, nonetheless retains with mind unshaken a true and steadfast perception of those things which he ought rationally to seek or avoid". I adopt Dyson's translation, making some modifications on the basis of T.H. Irwin's translation when that seems more exact. See Irwin 2003, 435. See also Quaestiones in Heptateuchum 1.30, where Augustine discusses the same passage from Aulus Gellius, using the terms perturbatio and affectio instead of passio. 
in accordance with Gellius' original version:

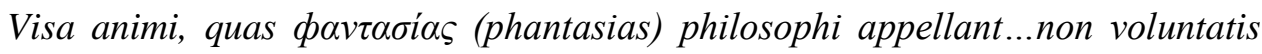

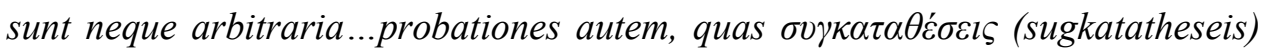
vocant, quibus eadem visa noscuntur, voluntariae sunt fiuntque hominum arbitratu. Propterea cum sonus aliquis formidabilis aut caelo aut ex ruina...sapientis quoque animum paulisper moveri et contrahi et pallescere necessum est, non opinione alicuius mali praecepta, sed quibusdam motibus rapidis et inconsultis officium

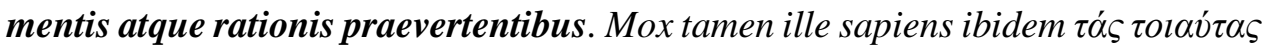

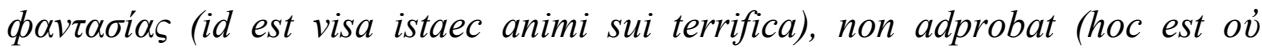

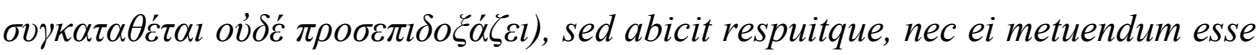
in his quicquam videtur. Atque hoc inter insipientis sapientisque animum differre dicunt, quod insipiens, qualia sibi esse primo animi sui pulsu visa sunt saeva et aspera, talia esse vero putat et eadem incepta, tamquam si iure metuenda sint...sapiens autem, cum breviter et strictim colore atque vultu motus est, ov

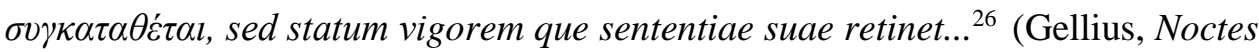
Atticae 19.1.15-20)

Gellius consistently interprets first movements as reactions to visa animi, "rapid and unpredictable movements that run ahead of the function of the mind and reason" (motibus rapidis et inconsultis officium mentis atque rationis praevertentibus). In addition, Gellius states that the Stoics also admit that neither the fool nor the sage are able to avoid such involuntary movements of the soul (for example, turning pale), but these are not based on any accepted beliefs in evil (non opinione alicuius mali praecepta). Indeed, the first movements become passions only when the voluntary assent follows and phantasiai are turned into sunkatatheseis.

26 "Mental images (visa animi), which the philosophers call phantasiai...do not belong to the will and are not in one's control...but approvals (probationes), which they call sunkatatheseis, by which these images are recognized, are voluntary and come about by a human being's control. Therefore, when some frightening sound comes from the sky or from a falling building...it is necessary for even the mind of the sage to be for a moment moved and to shrink and to grow pale, not because any belief in any evil has been accepted, but because of some rapid and unpremeditated movements that run ahead of the function of mind and reason. Soon, however, that sage does not endorse - that is to say, does not assent to, and does not add his belief to - such phantasiai - namely these frightening images (visa) - but he rejects and repudiates them, and nothing in these images seems (videtur) to him to be something to be feared (metuendum). And this, the Stoics say, is the difference between the fool and the sage, that the fool supposes things to be really as harsh and severe as they appeared to him to be when his mind was first struck, and once he has received them, also endorses them with his assent and adds his belief to them, as though they were rightly to be feared...The sage, however, while he is changed in complexion and facial expression for a short time and to a limited degree, does not assent, but at once holds on to the strength of his opinion". Apart from a minor revision, this translation is quoted from Irwin. Irwin 2003, 435. 
A comparison of these two paragraphs reveals a clear change in Augustine. At the beginning, he adopts Gellius' interpretation, but soon replaces the concept of "unpremeditated movements" (motibus inconsultis) by "passions running ahead of the function of the mind and reason" (his passionibus praevenientibus mentis et rationis officium). This is his deliberated choice. Moreover, it seems that he also follows Gellius when he substitutes "pavescat" (jitters) for "pallescere" (pale) by merely changing the letters "ll" to " $v$ ". ${ }^{27}$ The Stoics would probably not accept this minor adaptation, since it could be interpreted as altering their basic position. However, the question arises as to why Augustine uses the word "passion" rather than other terms. Does he really misunderstand the Stoics, or are there other reasons for using this word? To analyse Augustine's position, let us turn to compare some of his early and middle period writings (ca.395-410) as well as his late work, De civitate Dei.

In his early works, such as De musica $(6.5 ; 6.9 ; 6.10)$, De quantitate animae (23.41; 28.54), Contra Academicos (3.18; 3.21; 3.26), Epistulae (7.1-7; 9.4-5), Augustine states that judgements cause emotions. He proposes that judgements are based on the close connection between corporeal sensory suggestions and mental awareness. However, Augustine clarifies this by stating that merely sensory reactions that assail the soul on the first touch, such as sensual rhythms (numerositates sensibilium), impulses (appetitus), or sensory stimuli, do not represent passions. These sensual reactions make the soul produce the images of bodies (imagines corporum) or impressions (phantasia). Furthermore, a time-span exists between the first touch of the soul and the assents ( $\sigma 0 \gamma \kappa \alpha \tau \alpha \theta \varepsilon \dot{\varepsilon} \sigma \varepsilon \varsigma$ ) of "attention" (or "awareness"). Sensory affections are common to both animals and men; the assent distinguishes animal affection and rational perception. Augustine emphasises that significant conditions for perception are "attention" (attentio), "mental concentration" (cogitationis intentio) and "awareness" (non latere) and these, together with "judgements", form the origin of emotions. ${ }^{28}$ Augustine illustrates the course from the sensual rhythms and bodily affection, which both animals and men share, to the perception and emotional evaluation of the mind as follows:

\footnotetext{
${ }^{27}$ See note 5 in this chapter and $C D 9.4$

${ }^{28}$ See O’Daly 1987, 84-87.
} 
(1) Deinde uidit in motibus corporum aliud esse, quod breuitate et productione temporis uariaretur, in quantum magis esset minusue diuturnum, aliud localium spatiorum percussione in quibusdam gradibus celetiratis et tarditatis. Qua diuisione facta illud, quod in temporis mora esset, modestis interuallis et humano sensui adcommodatis articulatim uarios efficere numeros eorumque genera...Postremo adtendit, quid in his moderandis, operandis, sentiendis, retinendis ageret anima, cuius caput ipsa esset...quid est, quod in sensibili numerositate diligimus? (mus. 6.10.25-26) ${ }^{29}$

(2) sicut aliud est ad ea, quae corpus patitur, moueri, quod fit in sentiendo, aliud monere se ad corpus, quod fit in operando, aliud quod ex his motibus in anima factum est continere, quod est meminisse, ita est aliud adnuere uel renuere his motibus, aut cum primitus exeruntur, aut cum recordatione resuscitantur, quod fit in delectatione conuenientiae et offensione absurditatis talium motionum siue adfectionum, et aliud est aestimare, utrum recte an secus ista delectent, quod fit ratiocinando. (mus. 6.9.24) ) $^{30}$

(3) nam sensum puto esse, non latere animam quod patitur corpus. Placet mihi haec definitio. (quant. anim. 23.41) $)^{31}$

(4) sensu enim nos multae bestiae superant...mente autem, ratione, scientia, nos illis deus praeposuit. Sed ille sensus ea quibus tales animae delectantur, accedente consuetudine cuius magna uis est, potest discernere; atque eo facilius, quod anima belluarum magis corpori affixa est, cuius sunt illi sensus quibus utitur ad uictum uoluptatem que quam ex eodem illo corpore capit. (quant. anim. 28.54) ${ }^{32}$

\footnotetext{
29 "Then it noticed that there was one thing in the movements of bodies, which varied with respect to shortness or length of time, inasmuch as it was of longer or shorter duration, and another thing that varied with respect to the beating of local spaces with respect to certain degrees of speed and slowness. Having made this division, it continued to turn that which was in the time-span, properly divided with well-measured intervals that were adapted to the human perception, into various rhythms...Finally, it directed its attention to the way in which the soul, of which it was the head, was active in moderating, activating, perceiving and retaining these rhythms... what is it that we enjoy in the sensual rhythmicality?" Martin Jacobsson, AURELIUS AUGUSTINUS.DE MUSICA VI: A Critical Edition with a Translation and an Introduction (Institutionen för klassiska språk, Stockholm 2002), 61. For a similar clarification, see De musica 6.10.27-33.

30 "As it is one thing to be moved towards the reactions of the body, which occurs in perceiving, another to move oneself towards the body, which occurs in an activity, yet another thing to retain what has been produced in the soul as a result of these motions, which is to remember, so it is one thing to approve or disapprove of these motions, either when they are first set in motion or when they are revived by remembrance, which occurs in the pleasure of that which is convenient and in the dismay of that which is inappropriate in such motions or reactions, and another thing to evaluate whether it is right or not to enjoy these things, which is done by reasoning". (mus. 6.9.24). Ibid., 59. 31 "I hold perception to be the soul's awareness of that which the body experiences". [transl. O'Daly] (O'Daly 1987, 86). O'Daly argues that Augustine's definition of perception (or "under awareness", non latere) is influenced by the Stoic concept of sunaisthesis (awareness). O'Daly 1987,86 and n. 15.

32 "For many animals surpass us in their perceptive power...God has, however, made us superior to them in mind, reason, and knowledge. But the aforementioned faculty of perception can, together with habit, whose power is great, discern what gives pleasure to such souls; and all the more readily, as the soul of animals is more attached to their body, whose senses are used by it with a view to
} 
(5) Omnes has imagines, quas phantasias cum multis uocas, in tria genera commodissime ac uerissime distribui uideo: quorum est unum sensis rebus impressum, alterum putatis, tertium ratis...In hac tota imaginum silua credo tibi non uideri primum illud genus ad animam, priusquam inhaereat sensibus, pertinere...Quo fit, ut nullo pacto animam credam nondum corpore sentientem, nondum per sensus uanissimos mortali et fugaci substantia uerberatam in tanta falsitatis ignominia iacuisse. (Ep. 7.4-5) ${ }^{33}$

(6) si cupiditas nostra non mouebitur ad peccandum, excludetur serpentis astutia; si autem mota fuerit, quasi mulieri iam persuasum erit. Sed aliquando ratio uiriliter etiam commotam cupiditatem refrenat atque compescit. Quod cum fit, non labimur in peccatum, sed cum aliquanta luctatione coronamur. (Gn. adv. Man. 2.14.21) $)^{34}$

These earlier views can also be detected in Augustine's middle period writings of De Trinitate 9.6.10 and De Genesi ad litteram 12.12.25 (and 12.15.31), in which he describes the images of bodies (phantasias corporalium) before the approval or rejection of the mind (approbamus aut improbamus). ${ }^{35}$ Augustine makes the following observation:

...when we are awake, and our minds not alienated from the senses of the body, we are then in a state of bodily vision, and able to distinguish from it the spiritual kind, in which we think about absent bodies in images...From all of these we easily distinguish the bodily realities we do see with our bodily sense of sight fixed on them there in front of us. ( $\mathrm{Gn}$. litt. $12.12 .25)^{36}$

Augustine adds that if one is sleeping and reacts to affective representations

sustenance and the pleasure which derives from that same body". O'Daly 1987, 98.

33 "All these mental images, which you, like many others, call fantasies, I think can be most conveniently and most correctly divided into three classes: the first comprises true sense impressions; the second, images of things supposed; the third, of things thought...In this whole forest of images, you do not, I suppose, claim that the first class refers to the mind before it has the use of the senses...Consequently, I do not believe that the soul, before it has the use of a body, before it is beaten upon by the vain senses in a mortal and perishable substance, lies in such degradation of error". [transl. Parsons]

34 "When our cupidity is not moved toward a sin by the suggestion, the intrigues of the serpent are baffled. If it is moved, the woman is already persuaded, but sometimes the reason manly stops the movement of cupidity and destroys it and so we do not slide into sin but win it by fighting". [transl. Teske] (See Knuuttila 2004, 170).

35 De Trin. 9.6.10: unde etiam phantasias rerum corporalium per corporis sensum haustas et quodam modo infusas memoriae, ex quibus etiam ea quae non uisa sunt ficto phantasmate cogitantur siue aliter quam sunt siue fortuito sicuti sunt, aliis omnino regulis supra mentem nostram incommutabiliter manentibus uel approbare apud nosmetipsos uel improbare conuincimur cum recte aliquid approbamus aut improbamus. Nam et cum recolo carthaginis moenia quae uidi et cum fingo alexandriae quae non uidi easdem que imaginarias formas quasdam quibusdam praeferens, rationabiliter praefero.

${ }^{36} \mathrm{Gn}$. litt. 12.12.25: Sed cum vigilantes, neque mente a sensibus corporis alienata, in visione corporali sumus, discernimus ab ea visionem spiritalem, qua corpora absentia imaginaliter cogitamus...Ab his omnibus ita discernimus illa corporalia quae videmus, et in quibus praesentibus sunt sensus corporis nostri. Translations of Augustine's De Genesi ad litteram in this chapter are taken from Edmund Hill's edition (Hill 2002). 
in his dream, he is without sin:

...when the mental pictures that occur in his thoughts while he is speaking are also imprinted on his vision while he is dreaming in such a way that he cannot distinguish between them and the real coupling of bodies, the flesh is at once stirred into movements, and the result is what usually follows upon this movement; and this happens without sin, just as when he was awake he said without sin what he undoubtedly thought about in order to say it. $(\text { Gn. litt.12.15.31) })^{37}$

In short, concupiscence is the inherited weakness for sinful things, which we have endured as a punishment for original sin, and this makes us experience evil desires. Involuntary disobedience is also a sign of original sin, but if it is controlled immediately, it is not a new personal sin: "We do not sin in having an evil desire but in consenting to it". ${ }^{38}$ Here Augustine is borrowing from the Stoic moral psychology and the distinction between a first movement and an assent to it. By employing the terms suggestio, delectatio and consentio, Augustine applies this analysis to the biblical story of Adam, Eve, and the serpent. ${ }^{39}$ To Augustine, a sin is neither a suggestion derived from one's attention to an object of carnal concupiscence or another evil inclination, nor is it the spontaneous incipient delectation of cogitation, provided that the higher part of the soul destroys it immediately when it is aroused (See also De Trin. 12.12). ${ }^{40}$ In these texts, Augustine considers the first movement as being spontaneous reactions to visions (visa) or images (phantasiai) without regarding them as sins. In fact, Augustine's interpretation corresponds to the Stoic doctrine of propatheia. For this reason, the arguments proposed by Sorabji and Peter King's that Augustine misunderstands the Stoics are unconvincing.

\footnotetext{
${ }^{37}$ Gn. litt. 12.15.31: porro ipsa phantasia, quae fit in cogitatione sermocinantis, cum ita expressa fuerit in uisione somniantis, ut inter illam et ueram conmixtionem corporum non discernatur, continuo mouetur caro et sequitur, quod eum motum sequi solet, cum hoc tam sine peccato fiat, quam sine peccato a uigilante dicitur, quod ut diceretur sine dubio cogitatum est.

38 Expositio quarumdam propositionum ex epistula apostoli ad Romanos, PL 35, 2066. See Knuuttila 2004, 169.

${ }^{39}$ Knuuttila 2004, 170.

40 Knuuttila 2004, 170. For a discussion regarding the inherited evil inclinations and their involuntary activations remaining sinful in Augustine, see Wu Tianyue, "Augustine on Involuntary Sin: A Philosophical Defense", in Augustiniana 59 (2009), 45-78; "Did Augustine Lose the Philosophical Battle in the Debate with Julian of Eclanum on Concupiscentia Carnis and Voluntas?" in Augustiniana 57 (2007), 7-30; "Rethinking Augustine's Adaptation of 'First Movements' of Affection", in The Modern Schoolman 87 (2010), 95-115; "Shame in the Context of Sin: Augustine on the Feeling of Shame in De civitate Dei" in Les Recherches de Théologie et Philosophie Médiévales 74 (2007), 1-31. Cf. Simo Knuuttila, "The Emotion of Shame in Medieval Philosophy", in Spazio Filosofico 5 (2012), 243-249; Nisula 2012, 254-262.
} 
However, in his later works, Augustine presents another picture, as in De civitate Dei and in some Sermones. At this stage, he is inclined to refer to first movements as "passions" rather than as "visions" or "images" or unpremeditated reactions to them, which differs from his previous formulations. For instance, in $C D$ 1.25, he paraphrases the case of the first movement of the sleeper in Gn. litt. 12.15.31 and argues that unconscious lusts (concupiscentialis inoboedientia) as first movements are passions and these passions are not sins: "To be sure, that lustful disobedience which still dwells in our dying members sometimes moves itself as if by its own law, apart from the law of our will: when we are asleep, for instance. In this case also, however, there is still no guilt in the body of one who does not consent". ${ }^{41}$ On that condition, Augustine defends his position that it is impossible to avoid the sudden perturbations of preliminary passions and it is also absurd for the Stoics to refuse good preliminary passions, such as compassion. ${ }^{42}$ Thus, Augustine tends to alter his previous position and turns to refute the Stoics by transforming the meaning of several terms and by using some metaphors. This transformation is present in the following changes:

1. Changing the concept of motibus inconsultis into passionibus praevenientibus and using pavescat instead of pallescere, as was evident in the case of Noctes Atticae in CD 9.4.

2. Modifying the connotation of bodily affection or reaction (passio corporis) in his early works (such as De musica and De quantitate animae) ${ }^{43}$ to an emotional term (cupidity) in $C D$ 1.25. Augustine often uses the expression of

${ }^{41}$ CD 1.25: Quod si illa concupiscentialis inoboedientia, quae adhuc in membris moribundis habitat, praeter nostrae uoluntatis legem quasi lege sua mouetur, quanto magis absque culpa est in corpore non consentientis, si absque culpa est in corpore dormientis! Although Augustine does not use the word passio here, he mentions concupiscentia and refers lustful disobedience (concupiscentialis inoboedientia) to an involuntary passion as a sort of first movement.

${ }^{42}$ Augustine criticizes the Stoics for arguing that it is evil and inhuman to blame some preliminary passions such as compassions; it would be more honourable for them to experience compassion rather than the fear of shipwrecks. See CD 9.5: Nam et misericordiam Stoicorum est solere culpare; sed quanto honestius ille Stoicus misericordia perturbaretur hominis liberandi quam timore naufragii...Nulla de virtutibus tuis nec admirabilior nec gratior misericordia est.

43 Augustine incorporates the term passio corporis in De musica and De quantitate many times, but these terms do not convey the meaning of emotional "passion". See mus. 6.5.10: videtur mihi anima cum sentit in corpore, non ab illo aliquid pati, sed in ejus passionibus attentius agere...et exerit adtentiores actiones suis quibusque locis atque instrumentis adcommodatas, tunc uidere, uel audire, uel olfacere, uel gustare, uel tangendo sentire dicitur, quibus actionibus congrua libenter adsociat et moleste obsistit incongruis. Has operationes passionibus corporis puto animam exhibere cum sentit, non easdem passiones recipere; Cf. quant. anim. 25.48: passio corporis per se ipsam non latens animam. 
passio corporis, but this passio does not have the meaning of emotional "passion", but rather refers to the "suffering" or "reaction" of the body. Thus far, by combining this notion with first movements, he is in line with the Stoics. But passio has the double meaning of both "suffering" and emotional "passion" in his era, which provides a basis for him to move from the "affection of the body" (passio corporis) terminology to the emotional use of "passion" as a means of refuting the Stoic position on the first movement.

3. Transforming the stage of the first movement into an emotion (perturbatio), such as fear, desire, or anger, which is associated with a psychological state of momentary doubt (dubitans) as a symptom of the human weakness and disobedience of those who do not have sufficient faith in God. Augustine explains this by citing the example of Peter's staggering with fear and desire in sinking into water in Serm. 80.6: "Peter too...staggered...he began to tremble...And yet when he grew afraid he cried out... Then the Lord took him by the hand and said...'Why did you doubt?'...This fulfilled what was said in the psalm: 'If', I said, 'my foot has slipped, your mercy, Lord, came to my help"', ${ }^{44}$ Augustine insists that such sudden attacks on the mind (first movements) are due to a lack of confidence in God. ${ }^{45}$ In addition, to refer to temptations that are actually passions, Augustine also uses "being tossed about by storms of desires". ${ }^{46}$

In these three cases, Augustine clearly changes his attitude and no longer follows the Stoic doctrine. Instead, he prefers to refer to the first movements as passions because he realises that they follow from hesitating (haesitans) and doubting (dubitans), a psychological state of infirmity (infirmitas) and desire

\footnotetext{
44 Serm. 80.6: Et Petrus praesumpsit, et titubavit...Tamen quando trepidavit, ad illum exclamavit...Tunc Dominus tenuit illi manum, et dixit: Modicae fidei, quare dubitasti?...ut impleretur quod dictum est in Psalmo: Si dicebam, Motus est pes meus; misericordia tua, Domine, adiuvabat me. Cf. Matthew 14:29-31. In Serm. 76.1, 76.8-9, 75.10, 19.4; Ep. 30, 2, 3.10-12, there are similar examples about Peter's doubts and hesitations with fear in the stormy sea. See also Byers 2003, 443-444.

${ }^{45}$ Serm. 75.4: Tamen, fratres, maxima perturbatio in ista navi non est, nisi in absentia Domini.

${ }^{46}$ Serm. 75.4: Sic et in ista navi, cum absens est Christus, suis quisque tempestatibus quatitur et iniquitatibus et cupiditatibus suis. Byers maintains that Augustine adheres to the Stoic view that a first movement is not yet a passion, but she has to admit that this case (Serm. 75.4-5) makes her confused because it seems that Augustine indeed uses such storms of desires (as first movements) to refer to passions. This demonstrates that Byers's argument is not without problems. "Somewhat confusingly, elsewhere in this sermon (Serm. 75.4-5), Augustine switches back and forth between using 'being tossed about by storms of desires' to signify temptations, as he does here, and using it to signify desires which are actually passions". Byers 2003, 444 (n. 82). See also "[being] tossed upon a sea of passions" in $C D$ 9.6.
} 
(fluctuat cupiditate). ${ }^{47}$ Augustine argues that these types of preliminary passions are due to an insufficient confidence in God. ${ }^{48}$ In other words, the feeling of sudden emotional insecurity or involuntary cupidity reflects the weakness of the human soul. These involuntary passions are due to the original sin, but they are not personal sins or evils. The case of Peter sinking into water illustrates how the first movement of fear derives from not having sufficient faith. Only by fully trusting in the Lord and by accepting the grace of God will he be made strong and overcome the insecurity of the perturbations of passions. In this way, Augustine shifts the discussion of first movements to a theological context and associates it with faith (fides).

When discussing these cases, Sarah Byers contends that Augustine consistently adheres to the Stoic doctrine of the first movement and that he does not alter his position of a first movement being merely a reaction to an image rather than a passion. Byers does not specify the reason for Augustine initially clarifying the Stoic interpretation of the first movement, but then substituting the movement triggered by phantasia with passio praeveniens officium rationis in $C D$ 9.4. Furthermore, Augustine's later remarks in De civitate Dei as well as some of his Sermones maintain that some first movements involve cupidity or fear with infirmity and doubt, and some are good passions (i.e., compassion). Yet Byers does not pay attention to the real intention of this type of argumentation by Augustine-his aim is to refute the Stoic "arrogant" claim that the wise philosophers can avoid the agitations of preliminary passions and that it is also inhuman for them to refute some good first movements. Sorabji and King notice this non-Stoic usage in $C D$ 9.4, but they ignore Augustine's theological argument and draw the wrong conclusion that Augustine misunderstands the Stoics. While the Stoics regard the first movements as morally neutral, Augustine takes them as incitements that often reveal the sinful inclination of the fallen soul. The Stoics do not recognise the inherent sinfulness of the soul, which makes many of the first movements evil even before the involvement of the reason and will.

We can therefore recognise that Augustine's insight into the issue of first

\footnotetext{
${ }^{47}$ Serm. 76.9: Sed cum fluctuat cupiditate cor tuum, ut vincas tuam cupiditatem, invoca Christi divinitatem.

${ }_{48}$ Serm. 76.6: Ergo ambulavit Petrus super aquas in iussu Domini, sciens hoc se a se habere non posse. Fide valuit quod humana infirmitas non valeret.
} 
movements involves a complex process of adjustment and modification and there are significant differences between his early, middle and late works. In an overview on his account of the first movements in various stages, I do not think that Augustine misunderstands the Stoics. On the contrary, there is ample evidence that Augustine deviated from the Stoic position, attempting to evaluate involuntary passions from a theological orientation and endeavouring to find suitable measures to control and moderate those passions. This is closely related to his understanding of the two pivotal concepts, metriopatheia and apatheia, which will be analysed in the next section.

\subsection{Disputation on Augustine's Misunderstanding of Metriopatheia and Apatheia}

A similar controversy pertains to Augustine's comments on metriopatheia and apatheia. In $C D$ 9.4, Augustine claims that the difference between the Stoics and the Peripatetics regarding the therapy that aims at metriopatheia or apatheia is verbal. ${ }^{49}$ Sorabji argues that this statement demonstrates Augustine's misunderstanding of the distinction between metriopatheia and apatheia. According to Sorabji, there are substantial differences between these concepts in Stoicism and Peripateticism that cannot be referred to as a simple verbal dispute. ${ }^{50}$ However, some opponents, such as Irwin, maintain that there is no misunderstanding and that Augustine is justified in pointing out that the doctrines of his predecessors are essentially the same.

Sorabji asserts that Augustine misunderstands the Stoic doctrine of apatheia and erroneously obscures it with the Platonic-Peripatetic notion of metriopatheia. Sorabji explains that according to the Stoics, a wise man is able to

\footnotetext{
49 Augustine says, "It seems to me, therefore, that here also, when it is asked whether the passions of the mind affect the wise man or whether he is entirely a stranger to them, the controversy arises out of words rather than things. For I consider that, as far as the pith of the matter is concerned, rather than the mere sound of words, the view which the Stoics hold is no different from that of the Platonists and Peripatetics". (CD 9.4: Videtur ergo mihi etiam in hoc, ubi quaeritur utrum accidant sapienti passiones animi, an ab eis sit prorsus alienus, de verbis eos potius quam de rebus facere controversiam. Nam et ipsos nihil hinc aliud quam Platonicos et Peripateticos sentire existimo, quantum ad vim rerum adtinet, non ad vocabulorum sonum.)

50 "It has often been said that the dispute on apatheia and the other disputes... are merely verbal. On the whole, I believe the opposite is the case...sometimes the idea that the dispute is merely verbal rests, I believe, on misunderstanding the distinctions that I have been analyzing... what is going on here, I think, is not a verbal dispute at all, but an attempt to disguise a substantive dispute as if it were merely verbal”. Sorabji 2000, 207 and 209.
} 
maintain apatheia and defend himself against the perturbations of passions. However, the Stoics do not consider the first movements assailing the wise to be emotions, since they regard emotions as judgements of the mind and first movements as mere impulses. Augustine, on the other hand, maintains that the Stoic first movements are emotions. Thus, Augustine incorrectly assumes that it is impossible for Stoic philosophers to maintain apatheia and withstand the sudden disturbance of involuntary passions (first movements). In other words, what they refer to as apatheia is, in fact, equivalent to the Platonic-Peripatetic metriopatheia. ${ }^{51}$ Sorabji considers it to be important to recognise that there are clearly substantial disagreements between the Stoic and the Platonic-Peripatetic philosophers on the issue of the moderation and extirpation of emotions. Firstly, the Stoics refer to emotions as diseases, which essentially differs from the Peripatetic doctrine. ${ }^{52}$ To the Stoics, moderating emotions is basically tantamount to moderating perturbations (moderatae perturbationes), diseases (morbi), evils (mala), or vice (vitium). Moderation is a near scandal for Seneca, Cicero and the classical Stoics such as Chrysippus. ${ }^{53}$ Second, the concepts of metriopatheia and apatheia are based on two different theories regarding the soul: The Stoics defend the doctrine of apatheia, arguing that the soul is a unitary whole that has no naturally existing emotional part. Thus, they regard emotions as perturbations or diseases that should be eliminated from the soul in order to keep one's peace of mind and to foster virtues. The Peripatetics, on the other hand, defend the notion of metriopatheia because they believe that the soul is tripartite and that emotions are a function of the lower parts of the soul and cannot be extirpated. Therefore, Augustine's claim that “metriopatheia and apatheia are only verbally different

\footnotetext{
51 Sorabji contends that the reason for Augustine misunderstanding the Stoic apatheia is that he first misinterprets their concept of first movements and then falsely argues that the Stoics cannot attain apatheia because they have first movements. "We saw him in the City of God defending his belief in moderate emotion for humans in this life by claiming (erroneously) that even the Stoics would allow a little fear in a storm at sea. That was how he (mis)-interpreted the Stoic recognition of first movements...If we take Stoic apatheia to involve freedom from love and gladness, he says, it is not desirable at any time" (Sorabji 2000, 397-398); "emotions are not seen in the Stoic way as necessarily having the permission of reason. This can help to explain how in City of God 9.4 Augustine can so ignore the Stoic position as to claim that the wise man has emotions". (Ibid., 383) 52 "But their [Stoic] seeing emotions in terms of disease represents a substantive disagreement". Ibid., 207.

${ }^{53}$ Sorabji supposes that Chrysippus is the main establisher of the Stoic view of freedom from pathos, rather than Zeno, Panaetius, or Posidonius. Chrysippus is a classical representative of the Stoics, who contends apatheia and regards emotions as false judgements. Ibid., 206-207 and 181.
} 
rather than things" (de verbis eos potius quam de rebus facere controversiam) disregards the above substantial doctrinal distinctions. Furthermore, by examining the history of Christian predecessors' (such as the Alexandrians, Cappadocians, Evagrius, and Jerome) attitudes towards the Stoic ideal of apatheia, Sorabji argues that the following reasons led Augustine to his misinterpretation and blurred the distinction between metriopatheia and apatheia:

(1) Augustine was misled by his Christian predecessors. Augustine was influenced by the Latin translations of works by Origen and some other Christian Fathers and this obscured the distinction between first movements and emotions, mistaking propatheia as a reference to emotions. ${ }^{54}$ Augustine adheres to this perspective and presupposes the Stoics to be false in claiming that they could keep apatheia and resist such sudden passions.

(2) Cicero misguided Augustine. Cicero assumes a Stoic position and characterises the Peripatetic way of moderating emotions as moderating perturbations or moderating evils. Sorabji argues that Cicero translating pathos as "perturbation" lead Augustine to the misconception that the Stoic impassibility and the Peripatetic moderation are similar since both pertain to resisting emotions as perturbations or diseases. ${ }^{55}$

(3) Galen mislead Augustine, inducing him to make the assumption of a “verbal distinction". Sorabji refers to Galen's On the Diagnosis and Therapy of the Distinctive Passions of the Individual's Soul, in which Galen asks whether moderation assumes a similarity between strong passions and minor passions. ${ }^{56}$

Irwin dissents from the above argument and maintains that Augustine's notion of a mere verbal distinction between the concepts of metriopatheia and apatheia is reasonable and defensible. Irwin argues that Augustine understands the Stoics very well, and that there is indeed no essential difference between the Stoic and Peripatetic positions regarding these two conceptions. Irwin's reasoning is introduced below.

Firstly, both the Stoics and the Peripatetics acknowledge the existence of

\footnotetext{
54 Ibid., 382.

55 Ibid., 208-209.

56 "The wittiest verbal legislation along these lines is that of Galen, who says: It is no longer so clear whether being moderately disturbed in mind at a great loss of money or esteem belongs to the class of pathe, and similarly for being rather out of control in eating cakes". Ibid., 209.
} 
the state of propatheia. The Stoics, however, describe this a stage of "suggestive appearances", whereas the Peripatetics understand it as a stage of "passions". Augustine concludes that the two philosophies merely employ different terms to describe the same thing, propatheia. According to Augustine, the only problem is that the Stoics will not acknowledge that a propatheia is a passion. ${ }^{57}$ Thus, the Stoic apatheia does not exist, and instead its essence lies in the Peripatetic metriopatheia.

Secondly, both the Stoics and the Peripatetics emphasise the function of the judgement of one's mind upon passions, believing that people often go wrong in living by their passions alone and neglecting the analysis of their mind. ${ }^{58}$ Thus, passions are regarded as the object of rational adjustments, whether through moderation or elimination. Both metriopatheia and apatheia foreground the controlling of passions by the moral judgments of the mind, in order to realise the moral assessment of appropriate human actions. ${ }^{59}$

Thirdly, on this basis, "the same distinctions between responsible and non-responsible actions will be marked in different terms, and the same agents will count as responsible because of the same features". ${ }^{60}$ Consequently, Irwin argues that the Aristotelian position is close to the substance of the Stoic position, and that Augustine's remarks demonstrate the same feature. ${ }^{61}$

Even though Sorabji and Irwin present contrary arguments and evidence, they both appear to be defensible and persuasive. In order to evaluate the thesis of Augustine's alleged misinterpretation, and to consider other possible reasons for arguing that there is no essential distinction between apatheia and metriopatheia, I shall first analyse Augustine's accounts in his early, middle, and late works.

Augustine refers to the Stoic apatheia (impassibilitas) in his early works (before the mid-390s), such as De musica (6.16.51-55), De moribus ecclesiae

\footnotetext{
${ }^{57}$ Irwin 2003. 437.

58 "Both Peripatetics and Stoics believe that passions explain actions; people go wrong because they live in accordance with their passions". Irwin 2003, 438.

59 "The Stoics can strengthen their case by appealing to another feature of human action on passions that the Peripatetics also recognize...Aristotle insists on this point, and sharply criticizes people who try to evade moral judgments on their actions by pleading that they acted on their non-rational desires". Ibid., 439.

${ }^{60}$ Ibid., 439.

61 “Augustine's claim about the merely verbal difference between Stoics and Peripathetics on passions is defensible, since one might reasonably claim that the second interpretation of Aristotle brings him close to the substance of the Stoic position”. Ibid., 440.
} 
Catholicae et De moribus Manichaeorum (1.27.53-54), De ordine (2.6.18), and Contra Academicos (1.4.11). ${ }^{62}$ These works indicate that he was profoundly influenced by the Stoic conception of impassibilitas and pursued the contemplative state of a fully controlled soul with no suffering or disturbances. Augustine appreciated this type of impassibility as well as the related four virtues of the perfect soul: prudence, temperance, fortitude, and justice. He observes the following:

(1)...tu negabis in illa perfectione ac beatitate animam constitutam, et conspicere ueritatem, et immaculatam manere, et nihil molestiae pati posse, et uni Deo subdi, caeteris uero supereminere naturis?...Haec ergo contemplatio, sanctificatio, impassibilitas, ordinatio eius, aut illae sunt quattuor uirtutes perfectae atque consummatae, aut, ne de nominibus, cum res conueniant, frustra laboremus, pro istis uirtutibus, quibus constituta in laboribus utitur anima, tales quaedam potentiae in aeterna ei uita sperandae sunt. (De musica 6.16 .55$)^{63}$

(2) Magister: Cum ergo id agit, ne ulterius id delectet aliquando, nonne tibi uidetur amorem suum figere in Deo, et ab omni inquinamento temperatissime et cautissime et securissime uiuere? Discipulus: Videtur sane. (De musica 6.16.53) ${ }^{64}$

(3) Nam definitionem meam tu probasti, qua dictum est, quid sit esse cum Deo, cum quo mentem sapientis manere immobilem me, quantum assequi ualeo, docere uoluistis... fortasse enim, quia ubique deus est, quoquo ierit sapiens, inuenit deum, cum quo esse possit...Fateor, inquit, corpus illud de loco in locum transitum facere, sed mentem ipsam nego, cui nomen sapientis inpositum est. (De ordine 2.5.17-2.6.19) ${ }^{65}$

\footnotetext{
${ }^{62}$ These works date from the period between 386 and 391: De moribus ecclesiae catholicae (written in 388 and revised in 390), De musica (387-391), De ordine (Nov. 386-Mar. 387), and Contra Academicos (Nov.386-Mar.387).

63 "will you deny that the soul, dwelling in this perfection and beatitude, is capable of seeing the truth and of remaining without stain and of suffering no trouble and of being subject to the one God but superior to all other natures?...Thus, this contemplation, sanctification, impassibility and ordering of the soul, it is either those four virtues in a perfect and fulfilled state, or - not to waste energy on words, since there is agreement with respect to the things - some such faculties instead of the virtues, which the soul uses while laboring here, that are to be hoped for by the soul in the eternal life". [transl. Martin Jacobsson]

64 "M: So, when the soul is active with the purpose of never again taking pleasure in this, does it not seem to you to fix its love in God and live in complete temperance and caution and security from all impurity? D: Yes, it does". [transl. Martin Jacobsson]

65 "'You indeed accepted my definition, in which it was declared what 'to be with God' means, and, as far as I can get your meaning, you wished to teach that the mind of a wise man remains immovable with Him'...Perhaps, because God is everywhere, then, wheresoever the wise man goes, there he finds God, with whom he can be...'I admit', he said, 'that the body makes a transition from place to place, but I deny that the mind itself, to which the name of wisdom is given, makes such transition"”. [transl. Robert Russell]
} 
(4) ...quis non concedat ab omni miseria liberum esse debere sapientem ...etiamsi id faciat mente tranquilla, nullis aculeis doloris instinctus, sed adductus officio bonitatis, misericors tamen uocandus est. huic enim nihil obest nomen, cum absit miseria. (De moribus ecclesiae 1.27 .53$)^{66}$

(5) Uiximus enim magna mentis tranquillitate ab omni corporis labe animum uindicantes et a cupiditatium facibus longissime remoti, dantes, quantum homini licet, operam rationi, hoc est secundum diuinam illam partem animi uiuentes, quam beatam esse uitam hesterna inter nos definitione conuenit. (Contra Academicos 1.4.11) ${ }^{67}$

In excerpts (1), (2) and (3), Augustine emphasises the significance of keeping the mind immovable (mens immobilis) in order to be free from the emotional disturbance and to attain tranquility of the soul (tranquillitas animi). He adheres to the Stoic domination of reason, suggesting that the wise should beware all types of perturbations and develop impassibility (impassibilitas) and control (temperatissimus, cautissimus, securissimus). In this state, even virtuous emotions, such as compassion, should also be removed, retaining only compassionate acts without a feeling of pain, as explained in excerpt (4). ${ }^{68}$ In excerpt (5), Augustine highlights the constant mastering of one's soul, by which he intends to achieve two objectives, freedom from the flames of passions and contemplation with tranquility of the mind (in other words, impassibility). His arguments in these works (dating approximately from 386-392) display typical Stoic features, while also resembling Ambrose's notion of apatheia as fixing the focus of one's meditation on God and keeping one's mind unified with Him in a state of harmony. This indicates that at the beginning of his Christian life, Augustine was familiar with the Stoic concept of apatheia and that he was also influenced by its Platonist interpretation in Ambrose. ${ }^{69}$ It is therefore unlikely that Augustine did not know the Stoic doctrine

\footnotetext{
66 "Who does not allow that the wise man should be free from all such pain?...Although he performs these [compassionate] acts with a serene mind, impelled by the duty of kindness rather than the sting of pain, he ought still to be called merciful, for the word does not lose all meaning when the feeling of pain is absent". [transl. Martin Jacobsson, with a change]

67 "We lived in great mental tranquility, keeping the spirit free from every stain of the body; and, far removed from the raging flames of desire, we were taking pains, as far as man is allowed, to cultivate reason - that is, to live according to the divine part of the spirit - and this we agreed yesterday was by definition the happy life". [transl. Peter King]. See Peter King (transl.), Augustine, Against the academicians; The teacher (Indiana: Hackett, 1995).

${ }^{68}$ Augustine's view of compassion (or pity) in case (4) is in accordance with the Stoics, who believe that compassion is a form of mental pain and mistaken judgment of the mind which should be extirpated as well. For the Stoic teaching of compassion, see Brad Inwood, "Why do fools fall in love?" in Bulletin of the Institute of Classical Studies 41 (1997), 63 (n. 22).

${ }^{69}$ See Ambrose's De officiis 1.47.228-232; 1.48.233-239. Both Ambrose and Augustine refer to
} 
of apatheia or that he misunderstood it.

In his middle-period works such as Confessiones, Augustine expresses more pessimism concerning the human ability to remain apathetic in this life with respect to emotional experiences and the evil inclination of the soul. Rethinking the Stoic classification of emotions as appetite (cupiditas), pleasure (laetitia), distress (tristitia), and fear (metus), Augustine became convinced that due to the original sin, these emotions are necessarily included in the uncontrollable concupiscible and irascible movements. While Augustine had, in fact, familiarised himself with some Neoplatonic works around the time of his conversion to Christianity in $386,{ }^{70}$ having been influenced by Cicero and the Stoic psychological doctrines, ${ }^{71}$ Augustine did not emphasise the Platonic notion moderation in his early works during the years 386-390. It was only later in his Confessiones that he began to question the Stoic notion of impassibility and revise his perspective, particularly in reference to his weeping for a fraction of an hour (flevisse me matrem exigua parte horae) when faced with his mother's death in Conf. 9.12.33:

I was glad to weep before you about her and for her, about myself and for myself. Now I let flow the tears which I had held back so that they ran as freely as they wished. My heart rested upon them, and it reclined upon them because it was your ears that were there, not those of some human critic who would put a proud interpretation on my weeping. ${ }^{72}$

When referring to a proud criticism of weeping, Augustine seems to have in mind

emotions as perturbations and harmful phenomena, stressing that the reason should supervise the soul like a watchman in order to avoid any harassment (boni speculatoris est ita praetendere animo). In addition, both Ambrose and Augustine state emphatically that impassibility may help to attain mental tranquility and happiness when the focus of one's contemplation is fixed on God. Ambrose and Augustine also share many significant concepts, such as the four virtues (iustitia, prudentia, temperantia, and fortitudo) as well as the theory of emotional impulses (motus animi or impetu). Colish also maintains that in mor. 1.8.13-1.11.19; 1.26.48-1.28.58, Augustine parallels Ambrose's view on apatheia. See Colish 1985 (II), 222.

${ }^{70}$ In Conf. 7.9.13-14, Augustine mentions that he obtained some Neoplatonic books from a man who puffed up with pride. Conf. 7.9.13: procurasti mihi per quendam hominem, inmanissimo typho turgidum, quosdam Platonicorum libros ex graeca lingua in latinum versos. Peter Brown states that "they [these books] seem to have included many treatises of Plotinus, in the Latin translation of Marius Victorinus, and, possibly, one work at least, now lost, by Porphyry". Brown 2000, 85.

${ }^{71}$ In Conf. 3.4.7-8, Augustine mentions that when he read Cicero's Hortensius at the age of 18, his feelings were changed and he was deeply influenced by its teachings of happiness, immortality, and wisdom. He realised the vanity of the lower desires. Conf. 3.4.7: ...liber ille ipsius exhortationem continet ad philosophiam et uocatur Hortensius. Ille uero liber mutauit affectum meum et ad te ipsum...uiluit mihi repente omnis uana spes et immortalitatem sapientiae concupiscebam aestu cordis incredibili et surgere coeperam, ut ad te redirem. See comments in Chadwick 1991, 38-39; Knuuttila 2004, 164.

${ }^{72}$ Conf. 9.12.33: ...et libuit flere in conspectu tuo de illa et pro illa, de me et pro me. et dimisi lacrimas, quas continebam, ut effluerent quantum uellent, substernens eas cordi meo: et requieuit in eis, quoniam ibi erant aures tuae, non cuiusquam hominis superbe interpretantis ploratum meum. 
the Stoic conception of impassibility and their virtue of fortitude. As for maintaining impassibility or displaying passions at the death of his mother, he admits that it was impossible for him to bear the bitterness of grief and that weeping was a relief:

...so that you [Lord] can explain to me why weeping is a relief to us when unhappy? ...I merely grieved and wept. I was in misery and had lost the source of my joy. Or is weeping really a bitter thing which gives relief only when we cannot bear to think of the things which formerly we enjoyed, and which is pleasurable at the moments when we shrink from the memory of them? ${ }^{73}$

Augustine concludes that emotions are often supported by voluntarily formed habits that tend to take a direction different than that of pursuing righteousness, even though he attempts to struggle: "I was responsible for the fact that habit had become so embattled against me; for it was with my consent that I came to the place in which I did not wish to be" ${ }^{74}$ This descending tendency reveals the weakness of the human will and the sinful conditions generated by original sin. Thus, Augustine argues that emotions should be moderated because our weakened will does not have complete capabilities to eliminate them on the condition of being a sinner:

In this kind of way I was sure it was better for me to render myself up to your love than to surrender to my own cupidity. But while the former course was pleasant to think about and had my notional assent, the latter was more pleasant and overcame me... The law of sin is the violence of habit by which even the unwilling mind is dragged down and held, as it deserves to be, since by its own choice it slipped into the habit. ${ }^{75}$

However, in his late writings, such as De civitate Dei, Augustine makes the puzzling statement that metriopatheia and apatheia are essentially the same. This does not necessarily imply that he disregards the distinction between the Stoic and Platonic notions, as they both influenced him profoundly in his earlier years. Irwin argues that metriopatheia and apatheia indeed share many features and that Augustine merely reveals them. Sorabji, on the other hand, reasons that there are also many differences between them pertaining to different theories of the soul. I

${ }^{73}$ Conf. 4.5.10: ... ut dicas mihi, cur fletus dulcis sit miseris? ...sed tantum dolebam et flebam. miser enim eram et amiseram gaudium meum. an et fletus res amara est et prae fastidio rerum, quibus prius fruebamur, et tunc ab eis abhorremus, delectat?

${ }^{74}$ Conf. 8.5.11: sed tamen consuetudo adversus me pugnacior ex me facta erat, quoniam volens quo nollem perveneram. Cf. De sermone Domini in monte 12.34. See Knuuttila 2004, 169. For the power of habit in Augustine, see Rist 1994, 175-186.

${ }^{75}$ Conf. 8.5.12: Ita certum habebam esse melius tuae caritati me dedere quam meae cupiditati cedere; sed illud placebat et uincebat, hoc libebat et uinciebat...lex enim peccati est uiolentia consuetudinis, qua trahitur et tenetur etiam inuitus animus eo merito, quo in eam uolens inlabitur. 
propose that while both of these arguments reflect certain aspects of Augustine's perspective, they illustrate neither Augustine's true intentions, nor the crux of the matter. Augustine's remark reflects his mature considerations after long reflection. The main reason for Augustine making such a remark is that he addresses these philosophical conceptions from a theological perspective. When we return to the original context in $C D$ 9.4-5 and the related discussions in $C D$ 14.5-9, we will find that Augustine interprets the alleged "virtues" and "goods" differently from the Stoics and Platonists:

Certain philosophers, then, say that these disturbances or affections or passions assail even the wise man, though moderated and controlled by reason in that he imposes laws upon them by the mastery of his mind, by which they are reduced to their necessary limits. This is what the Platonists think, and the Aristotelians also, since Aristotle, who founded the Peripatetic school, was a pupil of Plato. Others, however, like the Stoics, believe that the wise man is not subject to passions of this kind... The other philosophers simply use the language of ordinary speech and call these things 'goods'; but they hold that, in comparison with virtue, which consists in living well, they are little things and of small value...For I consider that, as far as the pith of the matter is concerned, rather than the mere sound of words, the view which the Stoics hold is not different from that of the Platonists and Peripatetics. ${ }^{76}$

In this quote, Augustine argues that there is a similar core in the Platonic-Peripatetic model of moderation (metriopatheia) and the Stoic way of impassibility (apatheia), as they both emphasise the mastery of a mind that is not dominated by passions ${ }^{77}$ as well as the corresponding virtues (virtutes) without the disturbance of turbulent passions. Augustine also claims that with respect to virtue and justice, their disputations on whether to moderate or eliminate passions are completely unimportant. ${ }^{78}$ In Books 9 and 14 of the City of God, Augustine argues

\footnotetext{
76 CD 9.4: Has ergo perturbationes sive affectiones sive passiones quidam philosophi dicunt etiam in sapientem cadere, sed moderatas rationique subiectas, ut eis leges quodam modo, quibus ad necessarium redigantur modum, dominatio mentis_inponat. Hoc qui sentiunt, Platonici sunt sive Aristotelici, cum Aristoteles discipulus Platonis fuerit, qui sectam Peripateticam condidit. Aliis autem, sicut Stoicis, cadere ullas omnino huiusce modi passiones in sapientem non placet... Haec autem isti simpliciter et ex communi loquendi consuetudine appellant bona; sed in comparatione virtutis, qua recte vivitur, parva et exigua...Nam et ipsos nihil hinc aliud quam Platonicos et Peripateticos sentire existimo, quantum ad vim rerum adtinet, non ad vocabulorum sonum.

77 CD 9.4: Quae si ita sunt, aut nihil aut paene nihil distat inter Stoicorum aliorumque philosophorum opinionem de passionibus et perturbationibus animorum; utrique enim mentem rationemque sapientis ab earum dominatione defendunt.

${ }^{78}$ Augustine asserts that the Stoic philosophers' trembling and growing pale with fear should be regarded as passions, just as they are among the Peripatetics. Their dispute is concerned with mere terminology rather than fact, since they both pursue virtue and justice, arguing that passions should
} 
that for Christians, the factors that are most crucial for judging the quality of passions are virtues, justice, will, love, the grace of God, and salvation through Jesus Christ. In a theological context, philosophical conceptions are transformed and attributed new connotations, and as a consequence, the distinction between metriopatheia and apatheia loses its meaning. Thus, Augustine shifts the centre of the disputation and provides new criteria for evaluating the quality of passions.

\section{(I) Virtue (virtus) as a new criterion}

Augustine points out that the different attitudes toward passions in the philosophical schools and Christians are based on their different understandings of virtues. From Augustine's perspective, what the Stoics and Peripatetics refer to as virtues are, in a certain sense, cool and even inhuman. As Augustine remarks in $C D$ 9.4-5, both the Stoics and the Peripatetics attempt to control the fluctuation of turbulent passions, so as to direct the unfettered reason toward virtues and wisdom. The objective of both metriopatheia and apatheia is to pursue an unshaken mind without the perturbation of passions. To describe the Peripatetic control of passions, Augustine's cites from Virgil in CD 9.4: "His mind remains unmoved; tears flow in vain" (Mens inmota manet, lacrimae volvuntur inanes). At this point, Augustine is emphasising that Peripatetics pursue the virtue of fortitude by controlling the non-rational part of the soul (passions) through the work of reason. This is not substantially different from the Stoic position that passions cannot assail the fortitude of a wise man's mind.

As for Christians, Augustine argues that passions genuinely affect and touch their minds in the course of their exercise of virtues, rather than dragging them into vice (CD 9.5: Quod passiones quae Christianos animos afficiunt non in vitium trahant, sed virtutem exerceant). In other words, their virtues involve

yield to reason and the mind. CD 9.4: Quod autem aiunt ea nec bona appellanda esse, sed commoda, verborum certamini, non rerum examini deputandum est. Quid enim interest utrum aptius bona vocentur an commoda, dum tamen ne his privetur non minus Stoicus quam Peripateticus pavescat et palleat, ea non aequaliter appellando, sed aequaliter aestimando? Ambo sane, si bonorum istorum seu commodorum periculis ad flagitium vel facinus urgeantur, ut aliter ea retinere non possint, malle se dicunt haec amittere, quibus natura corporis salva et incolumis habetur, quam illa committere, quibus iustitia violatur... quin immo eis ipsa dominatur eisque non consentiendo et potius resistendo regnum virtutis exercet. The Stoics do not refer to the objects of the affects as good, but as advantages. In Augustine's opinion, this is merely playing with words. See R. Dodaro, Christ and the Just Society in the Thought of Augustine (Cambridge University Press, 2004), 58-59. 
passions. Augustine considers it to be impossible to withstand all emotions in this life; in some situations, it is vicious to have no emotions. Therefore, Augustine asserts that the question is not whether we can eliminate passions in this life, but rather which type of passions we should have and why:

We do not so much ask whether a pious soul is angry, as why he is angry; not whether he is sad, but whence comes his sadness; not whether he is afraid, but what he fears. For I do not think that any right-minded person would condemn anger directed at a sinner in order to correct him; or sadness on behalf of one who is afflicted, in order to comfort him, or hear for one in peril, lest he perish. The Stoics, indeed, are wont to reproach even compassion. But how much more honorable it would have been if the Stoic in Aulus Gellius' story had been disturbed by compassion for a fellow man, in order to comfort him, rather than by fear of shipwreck! ${ }^{79}$

For Augustine, in situations such as a shipwreck, what the Stoics refer to as apatheia without compassion for others is tantamount to a scandal. This is not a virtue, but a vice. ${ }^{80}$ Therefore, the concept of virtue has been transformed into Augustine's own context; it is not blameworthy to have passions, but honourable; on the contrary, virtues with human kindness also become the criterion that attests to Christian passions being honourable and praiseworthy.

\section{(II) The new concept of justice (iustitia)}

This does not imply that the Stoics or Peripatetics do not pursue justice; it is only that according to Augustine, their alleged justice is associated with insensitivity and negligence of human sociability. Referring to Gellius' story of the shipwreck, Augustine argues that compassionate people are those who indeed feel another person's misery in their heart and this compels them to offer aid. The emergence of these compassions involves three stages: firstly, one encounters someone's misery and this moves the soul suddenly as a first movement; secondly, this first movement yields to right reasoning; thirdly, just action follows:

And what is compassion but a kind of fellow feeling in our hearts for the misery of another which compels us to help him if we can? This impulse is the servant of right reason when

\footnotetext{
${ }^{79}$ CD 9.5: Denique in disciplina nostra non tam quaeritur utrum pius animus irascatur, sed quare irascatur; nec utrum sit tristis, sed unde sit tristis; nec utrum timeat, sed quid timeat. Irasci enim peccanti ut corrigatur, contristari pro adflicto ut liberetur, timere periclitanti ne pereat nescio utrum quisquam sana consideratione reprehendat. Nam et misericordiam Stoicorum est solere culpare; sed quanto honestius ille Stoicus misericordia perturbaretur hominis liberandi quam timore naufragii.

${ }^{80}$ For Augustine's objections to the Stoic values of compassion, see Irwin 2007, 405-406.
} 
compassion is displayed in such a way as to preserve righteousness, as when alms are distributed to the needy or forgiveness extended to the penitent. ${ }^{81}$

It is evident that Augustine has modified his previous interpretation of compassion in De moribus ecclesiae 1.27.53 and Contra Academicos 1.4.11 and he no longer adheres to the Stoic teachings. To Augustine, compassion is admirable when it is in accordance with justice; however, the Stoic argumentation on compassion is superficial, without involving real personal care or feelings. Augustine mentions that Cicero disagreed with the Stoic view that compassion is vicious ${ }^{82}$ and adds that some Stoics seem to accept compassion in a Stoic sage. ${ }^{83}$ According to Augustine, compassion is required by God's justice and this becomes the criterion to evaluate the character of passions. If emotions and passions are called for by God's justice, then they are righteous and blessed; if they are derived from mundane matters and a sinful life, they are evil, as Augustine emphasized in $C D$ 14.9: "We must, then, lead a righteous life if we are to attain a life of blessedness; and such a righteous life will exhibit all these emotions righteously, whereas a perverse life exhibits them perversely". 84

(III) The quality of the will (voluntas) as a new indicator

Augustine distinguishes between the concept of will that is advanced by these philosophers from the concept of will advocated by Christians because these two groups have rather different understandings of human conduct. ${ }^{85}$ The Stoics and Peripatetics advocate that emotions should yield to reason and will, but Augustine states that human evaluation of reason is blurred and the human will has been

${ }^{81}$ CD 9.5: Quid est autem misericordia nisi alienae miseriae quaedam in nostro corde compassio, qua utique si possumus subvenire compellimur? Servit autem motus iste rationi, quando ita praebetur misericordia, ut iustitia conservetur, sive cum indigenti tribuitur, sive cum ignoscitur paenitenti.

${ }^{82}$ CD 9.5: Hanc Cicero locutor egregius non dubitavit appellare virtutem, quam Stoicos inter vitia numerare non pudet.

${ }^{83}$ CD 9.5: ...qui tamen, ut docuit liber Epicteti, nobilissimi Stoici, ex decretis Zenonis et Chrysippi, qui huius sectae primas habuerunt, huiusce modi passiones in animum sapientis admittunt, quem vitiis omnibus liberum volunt.

${ }^{84}$ CD 14.9: Quae cum ita sint, quoniam recta vita ducenda est, qua perveniendum sit ad beatam, omnes affectus istos vita recta rectos habet, perversa perversos.

${ }^{85}$ In commenting on the Stoic eupatheia of will, Augustine states: "But a distinction is to be made between the depravity of an evil will and the will of which the angels spoke when they proclaimed 'On earth peace, good will toward men.' The addition of the word 'good' here is redundant if will can only be good... Such an indiscriminate use of these terms is seen also among secular literature authors". CD 14.8: a cuius pravitate illa distinguitur, quam praedicaverunt angeli dicentes: Pax in terra hominibus bonae voluntatis. Nam ex abundanti additum est "bonae", si esse non potest nisi bona...Et apud auctores saecularium litterarum talis istorum verborum indifferentia reperitur. 
weakened after the Fall; for this reason, it is impossible to fully trust such an unsound reason or to rely on this distorted will. Due to original sin, the human will and passions are led by worldly temptations, and humans follow concupiscence and pride instead of pursuing genuine good. Under these conditions, the fundamental powers of reason and will that these philosophers based their views on metriopatheia or apatheia are, according to Augustine, not to be trusted.

Augustine maintains that the will of Christians should be governed and aided by God. This is the only way that passions may become righteous and virtuous. He emphasises this point in $C D$ 9.5:

Scripture, indeed, places the mind itself under the governance and help of God, and the passions under the mind, so that they may be moderated and bridled and turned to righteous use. ${ }^{86}$

For Augustine, when the philosophers argue for metriopatheia or apatheia, they are overconfident in their own will and power, which attests to their arrogance and conceit. On the contrary, the Christian understanding of will is pious and modest, as Christians are aware of their weakened position in this life as members of fallen humanity. They know that only through the grace of God the will may help in directing passions towards the good instead of the bad. Augustine transforms the discussion on reason and will into a theological consideration of the defect of the human will and the power of grace. This becomes the premise for evaluating passions, as Augustine explains in $C D$ 14.6:

What is important here is the quality of a man's will. For if the will is perverse, the emotions will be perverse; but if it is righteous, the emotions will be not only blameless, but praiseworthy. The will is engaged in all of them; indeed, they are all no more than acts of the will...And, universally, as a man's will is attracted or repelled by the variety of things which are pursued or avoided, so it changes and turns into emotions of one kind or the other. Therefore, the man who lives according to God and not according to man must be a lover of the good; and it follows from this that he must hate what is evil. ${ }^{87}$

The will is considered here as a person's basic motivational centre. Love is another

\footnotetext{
${ }^{86}$ CD 9.5: Deo quippe illa ipsam mentem subicit regendam et iuvandam mentique passiones ita moderandas atque frenandas, ut in usum iustitiae convertantur.

${ }^{87}$ CD 14.6: Interest autem qualis sit voluntas hominis; quia si perversa est, perversos habebit hos motus; si autem recta est, non solum inculpabiles, verum etiam laudabiles erunt. Voluntas est quippe in omnibus; immo omnes nihil aliud quam voluntates sunt...Et omnino pro varietate rerum, quae appetuntur atque fugiuntur, sicut allicitur vel offenditur voluntas hominis, ita in hos vel illos affectus mutatur et vertitur. Quapropter homo, qui secundum Deum, non secundum hominem vivit, oportet ut sit amator boni; unde fit consequens ut malum oderit.
} 
term that Augustine uses in the same manner; both are used in systematising the Stoic taxonomy of passions. ${ }^{88}$

\section{(IV) Love (amor) as a new measure}

Augustine maintains that the Stoic and Platonic-Peripatetic love is, in fact, disordered love that is replete with pride and disobedience. He suggests that we need to distinguish between the love (amor) that these philosophers harbour and the love of Christian believers. Even though the will is free in its basic orientation, it is not able to change its distorted orientation without supranatural causation (grace). The same holds true of love. ${ }^{89}$ The original sin is evident in the tendency that human love has to choose evil and sinful objects. This manifests itself in "the weight of will and love" (pondus voluntatis et amoris). ${ }^{90}$ In this state, the people's love is always directed towards themselves and their own honour rather than to the supreme and immutable good. This fallen tendency in people is pride (superbia) and is regarded as a defect, because they love the wrong object in the reverse order. Thus, to Augustine, Stoic and Peripatetic love is actually self-love and pride that displays human sinfulness. Furthermore, Augustine argues that it is inappropriate to evaluate the quality of a passion in terms of such a distorted and disordered love.

${ }^{88}$ CD 14.7: Amor ergo inhians habere quod amatur, cupiditas est, id autem habens eoque fruens laetitia; fugiens quod ei adversatur, timor est, idque si acciderit sentiens tristitia est. Proinde mala sunt ista, si malus amor est; bona, si bonus. ("Love striving to possess what it loves is desire; love possessing and enjoying what it loves is joy; love fleeing what is adverse to it is fear; and love undergoing such adversity when it occurs is grief. Accordingly, these feelings are bad if the love is bad, and good if it is good".)

${ }^{89}$ Conf. 13.9.10: Corpus pondere suo nititur ad locum suum...Pondus meum amor meus; eo feror, quocumque feror. Dono tuo accendimur et sursum ferimur; inardescimus et imus...Igne tuo, igne tuo bono inardescimus et imus, quoniam sursum imus ad pacem Hierusalem. ("A body by its weight tends to move towards its proper place...My weight is my love. Wherever I am carried, my love is carrying me. By your gift we are set on fire and carried upwards: we grow red hot and ascend...Lit by your fire, your good fire, we grow red-hot and ascend, as we move upwards 'to the peace of Jerusalem."') Cf. CD 13.5: Ut autem diligatur et delectet uera iustitia, non nisi diuina subuenit gratia. ("we cannot love or take delight in true righteousness unless with the aid of divine grace".) Augustine does not make an essential distinction between amor and dilectio, see CD 14.7.

90 Augustine applies the notion of pondus voluntatis et amoris in many places in City of God, such as $C D 11.16 ; 13.18 ; 19.12 ; 22.11$, etc. He also mentions it in his earlier writings such as mus. 6.11.29, Gn. litt. 4.3.7-4.5.12; 4.4.8; 4.18.34, De Trin. 6.10.12; 11.11.18, Conf. 13.9.10; 4.15.27; 7.17.23. Miikka Ruokanen points out that Augustine establishes his concept of ordo amoris on the dynamic principle of love. In the fallen state, the weight of the will and love (pondus voluntatis et amoris) has broken the good order and hierarchic harmony between rational beings and the Creator. Ruokanen notes that in Augustine's later years, he increasingly emphasised the disturbed and down-weighed reality of love in the state of sin, presenting pride and disobedience. This is not the proper order of love that is based on the correct orientation of life, but a perverted love that the source of all evils in human life. See Ruokanen 1993, 48-50. 
For it is a perverse kind of elevation indeed to forsake the foundation upon which the mind should rest, and to become and remain, as it were, one's own foundation. This occurs when a man is too well pleased with himself; and he is too well pleased with himself when he falls away from that immutable good with which he ought rather to have been pleased than with himself...For if the will had remained unshaken in its love of that higher and immutable Good by Which is bestowed upon it the light by which it can see and the fire by which it can love, it would not have turned aside from this Good to follow its own pleasure...This is why, according to Holy Scripture, the proud are called by another name: they are called 'self-willed'. For it is good to lift up your hearts; not to self, however, which is pride, but to the Lord. This is obedience, which can belong only to the humble. ${ }^{91}$

Augustine defends his idea as being based on Christian teaching and maintains that genuine love is from the Holy Spirit which pours love into our hearts. This principle of love is distinguished from that proposed by the Stoic and Peripatetic doctrines because it attributes the root of love to the highest point in the hierarchical order, the immutable love and good. This reflects modesty and in contrast to philosophers who establish the principle of love in themselves. In other words, Augustine argues that whether or not passions are good is based on the criterion of love that is derived from holy charity and God rather than from the pride of philosophers: "If these emotions and affections, which come from love of the good and from holy charity, are to be called vices, then let us allow that real vices should be called virtues". ${ }^{92}$

\section{(V) The mediator, Jesus Christ, as an example and the Saviour}

Augustine concludes that the central criterion is the mediator between humans and God, Jesus Christ, and He possesses all of the above virtues and represents a perfect unity between divinity and humanity. Christ's incarnation and emotional life reveal the profound mystery in the context of the issue of metriopatheia and apatheia. At this point, the disputation on metriopatheia and apatheia between these philosophers has lost its meaning. For Augustine, Christ's passions express

\footnotetext{
${ }^{91}$ CD 14.13: Perversa enim est celsitudo deserto eo, cui debet animus inhaerere, principio sibi quodam modo fieri atque esse principium. Hoc fit, cum sibi nimis placet. Sibi vero ita placet, cum ab illo bono inmutabili deficit, quod ei magis placere debuit quam ipse sibi...si voluntas in amore superioris inmutabilis boni, a quo inlustrabatur ut videret et accendebatur ut amaret, stabilis permaneret, non inde ad sibi placendum averteretur... Unde superbi secundum scripturas sanctas alio nomine appellantur sibi placentes. Bonum est enim sursum habere cor; non tamen ad se ipsum, quod est superbiae, sed ad Dominum, quod est oboedientiae, quae nisi humilium non potest esse.

${ }_{92}$ CD 14.9: Hi motus, hi affectus de amore boni et de sancta caritate venientes si vitia vocanda sunt, sinamus, ut ea, quae vere vitia sunt, virtutes vocentur. For the pride of philosophers, see Irwin 2007 , 418-427.
} 
humility and love, offering an ideal for humankind. Moreover, His suffering is a vital part of the divine economy of salvation that delivers sinners from suffering and sin and allows them to take part in His immortality and divine nature. ${ }^{93}$ In $C D$ 9.6, Augustine argues that according to Platonists, demons can become mediators and keep apatheia in front of the assailing of passions, since they possess the capability to use the superior part of the soul (reason) to govern and moderate the turbulent movements of lower part (passions). Augustine refutes this as impossible, as the demons' minds are also subject to the passions of fear and lust and unable to show true virtues and love. ${ }^{94}$ Augustine proposes three principles as the fundamental conditions for judging who is suitable as a mediator to save humans from passions: 1. In order for this mediator to understand true human passions, he must have as weak and mortal a body as humans do; 2 . This mediator must have an immortal and just spirit and a soul that is free of disease; 3 . This mediator does not lust for the temporal world and has the power of God to clean and redeem us. ${ }^{95}$ However, the demons, whom these philosophers attribute the fundamental criterion of passions to, are always contaminated by bad passions and are unable to save even themselves. Although these demons possess immortal bodies, they are worse than human beings. Certainly no one implies that they are better than humans, as they are regarded as wretched and thought to suffer from passions forever in eternal misery.

This, however, is the very reason for the eternal misery or miserable eternality of the demons. For he who said that they are 'passive in soul' would have called them 'miserable' had he not feared to offend their worshippers. Moreover, since the world is ruled not by the accidents of fortune, but by the providence of the supreme God - as even the Platonists themselves admit - the misery of the demons would not be eternal unless their wickedness were great. ${ }^{96}$

\footnotetext{
${ }^{93}$ In addition, see my discussion on "The Grace of Christ and the therapy of passions" in section 3.4. For the function of Christ as the mediator and Saviour, see Kelly 1977, 386-394.

${ }^{94}$ CD 9.6: sicut iste Platonicus confitetur, salo perturbationum fluctuat. Subiecta est ergo mens daemonum passionibus libidinum formidinum irarum atque huiusmodi ceteris...cum eorum mens passionum vitiis subiugata et oppressa, quidquid rationis naturaliter habet, ad fallendum et decipiendum tanto acrius intendat, quanto eam magis possidet nocendi cupiditas?

95 Augustine demonstrates these three principles in CD 9.17: sed tali, qui nobis infimis ex corporis mortalitate coaptatus inmortali spiritus iustitia, per quam non locorum distantia, sed similitudinis excellentia mansit in summis, mundandis liberandisque nobis vere divinum praebeat adiutorium. Qui profecto incontaminabilis Deus absit ut contaminationem timeret ex homine quo indutus est, aut ex hominibus inter quos in homine conversatus est.

${ }^{96}$ CD 9.13: Ipsa est autem illa daemonum misera aeternitas vel aeterna miseria. Qui enim ait "animo passiva”, etiam "misera” dixisset, nisi eorum cultoribus erubuisset. Porro quia providentia
} 
Therefore, Augustine holds that referring to demons as examples and criterions of freedom from passions by metriopatheia or apatheia is foolish because their passions reflect eternal misery and deceit and consequently indicate their unrighteousness, pride, disobedience, and inhumanity. In brief, to Augustine, demons cannot be true mediators, while Jesus Christ, by comparison, has real human passions (both voluntary and involuntary) as well as the divine "emotion" (immutable and transcendent), which reflect His perfect unity of divinity and humanity. Thus, Augustine states that Christ, as the form of God and the servant, indicates the road toward freedom from the domination of passions and eternal happiness. As regards metriopatheia or apatheia and the correct attitude toward passions, Augustine argues that Jesus Christ offers us a good example, although humans cannot achieve Christ's sinlessness in their present life.

In the light of the above analysis, it is clear that Augustine presents various views of the doctrines of metriopatheia and apatheia, instead of adhering to any of them consistently. In his early period from the year 386 to the mid-390s, he followed the Stoic teachings and his concept of apatheia was influenced by the interpretations of Cicero and some Christian Fathers, such as Ambrose and possibly Origen. Later, in Augustine's middle works, he realises the significance of metriopatheia and adopts a position on moderation that is influenced by Neoplatonism. These two periods reflect his rather clear understanding of the two conceptions. This also suggests that his later remarks regarding the lack of any essential distinction between metriopatheia and apatheia constitutes a deliberate formulation rather than something pertaining to ignorance or a misunderstanding. In his De civitate Dei, Augustine transforms many significant categories, such as virtue, justice, will, and love, into theological language and distinguishes them from their philosophical usage. To Augustine, demons, which are recommended as mediators by some Platonists, would not make good mediators to help humans free themselves from passions, because in terms of the model of Jesus Christ, their alleged virtues are in fact vice and their love is pride. Thus, Augustine suggests a new interpretation of metriopatheia and apatheia, arguing that it is not important to make this distinction between philosophical positions as a theological guide.

summi Dei, sicut etiam ipsi fatentur, non fortuita temeritate regitur mundus, numquam esset istorum aeterna miseria, nisi esset magna malitia. 
Adopting a new model of a mediator that incorporates the union between divinity and humanity, Augustine demonstrates that Jesus sets an example of controlling and moderating passions, in contrast to the proud philosophers who claim to be able to maintain apatheia or to moderate their passions with an unshaken mind (metriopatheia). It is in this context that he deliberately states that the doctrines of metriopatheia and apatheia are essentially the same; both are misleading without the grace.

From this perspective, it can be observed that Sorabji and Irwin do not take into account Augustine's true intentions, even though they offer insight into certain aspects of Augustine's terminology and ideas. As for Sorabji's argument that Augustine is misled by some predecessors' formulations of metriopatheia and apatheia, I conclude that it might be partially correct since Augustine was indeed once influenced by the Stoics and Cicero. However, Sorabji's conclusion that Augustine misrepresents the Stoic apatheia as metriopatheia seems hasty. Irwin correctly points out that Augustine had a rather sound understanding of philosophical positions, but Irwin does not reveal Augustine's real stance on the controversy. Both Sorabji and Irwin fail to consider Augustine's complicated shifts in positions during his life. Irwin might be correct in arguing that the notions of metriopatheia and apatheia share many common elements, but Augustine's interest does not lie here. Augustine is familiar with these two philosophical doctrines, and he deliberately remarks that there are no differences between them because he interprets the issue from a theological perspective. In this sense, Augustine's remark is reasonable and reveals the doctrinal weakness of both the Stoics and Platonists from his perspective.

\subsection{The Disputation about Augustine's Misunderstanding of Eupatheia}

After examining Augustine's understanding of propatheia, metriopatheia, and apatheia, scholars extend their considerations to another central Stoic concept

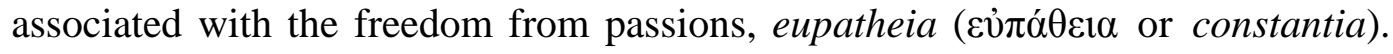
There is a controversy concerning whether or not Augustine misunderstands this concept. According to certain scholars, Augustine did misunderstand it, since he incorrectly claimed that the Stoic eupatheia is merely terminologically different 
from common passions, which is obviously not in accordance with the Stoic teaching. These scholars maintain that eupatheiai refer to correct value judgments and attitudes and belong only to the Stoic sage, but Augustine confuses these genuinely good judgments with the ordinary passions that are usually regarded as false value judgments. It is true, but not relevant, that the Stoic eupatheia indeed may include some ordinary passions and rational impulses. ${ }^{97}$ Furthermore, scholars report that Augustine reveals an even deeper misunderstanding of the Stoic ideal of freedom from passions when he interprets this emotional state as stupor, which obviously does not recognise the Stoic eupatheia as an ideal rational state concerning the genuine good rather than indifference. On the contrary, some other scholars maintain that Augustine understands the essence of the Stoic ideal of freedom from emotion, and his equating the Stoic ideal state of eupatheia with indifference is evidence of reinterpretation rather than misinterpretation. I shall explain this controversy and the competing positions pertaining to it.

Sorabji argues that Augustine displays a substantial misunderstanding of the Stoic term eupatheia and the ideal state of eradicating emotions. These misunderstandings are reflected on two levels: (1) As for the term eupatheia, Augustine blindly equates the sage's good judgments (eupatheia) with the fool's false value judgments (pathos), which obscures the boundaries between eupatheia and pathos. He incorrectly includes all eupatheiai as common passions and is misguided in his claim that there are merely verbal differences between them; ${ }^{98}$ and (2) Regarding the Stoic ideal of freedom from emotions, rather than grasping the Stoic original sense of the good ideal, Augustine mistakenly interprets the Stoic

97 There are different descriptions among these commentators of eupatheia as follows: 1. Eupatheia is an impulse of fully rational man and "apatheia is eupatheia" (Brad Inwood). 2. Eupatheia is a fully rational attitude (Margaret Graver, Gerd Van Riel and Martha Nussbaum). 3. Eupatheia is a good state towards genuine good rather than indifference (Tad Brennan). 4. Eupatheia is largely an ideal, including a few types of ordinary passions as well (Sorabji). I am inclined to accept both Tad Brennan's account that eupatheiai are directed towards genuine goods and Martha Nussbaum's position that eupatheiai are correct impulses to external indifferents (See Tad Brennan, "The Old Stoic Theory of Emotions", in The Emotions in Hellenistic Philosophy, ed. J. Sihvola and T. Engberg-Pedersen (Dordrecht: Kluwer 1998), 21-70; Nussbaum 1994, 379-399). I interpret this to mean that apart the value commitment, eupatheia is accompanied by an indifference to everything else. In this sense, it refers to a good judgement of the mind, reflecting an indifferent attitude towards external matters.

${ }^{98}$ Sorabji states that Augustine mispresents a series of Stoic psychological concepts one after another. He claims that the reason that Augustine misunderstands the term eupatheia is due to his first misconception of the Stoic belief of propatheia and apatheia. In the Index of Emotion and Peace of Mind, Sorabji maintains that Augustine "misrepresents Stoic belief in apatheia as verbal difference. Similarly for eupatheia. Similarly for indifferents”. See Sorabji 2000, 471. 
state of eradicating emotions as stupor and confuses it with indifference and mercilessness. ${ }^{99}$ Sorabji adopts an intermediary position in interpreting the Stoic concept of eupatheia. On the one hand, he contends that eupatheiai are ideal "good emotions" with a set of ordinary persons' emotions; on the other, he states that many emotions of eupatheiai belong to an ideal state. ${ }^{100}$ Sorabji argues further that Augustine does not grasp the essence of this term because the term eupatheia has complicated connotations in the Stoic doctrine, including ordinary emotions and ideal feelings at the same time. This means that Augustine's comprehension of the term is one-sided. Sorabji first lists the Stoic species of eupatheia in order to present that it is true that some eupatheiai could be counted as ordinary emotions in Stoicism: ${ }^{101}$

\begin{tabular}{|c|c|c|}
\hline \multicolumn{3}{|c|}{ Eupatheia } \\
\hline 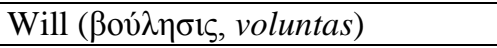 & 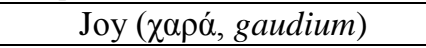 & 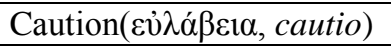 \\
\hline $\begin{array}{l}\text { Good will (eunoia) is wishing } \\
\text { good things for others for their } \\
\text { own sake }\end{array}$ & $\begin{array}{l}\text { Delight (terpsis) is a fitting } \\
\text { joy at one's advantages. }\end{array}$ & $\begin{array}{l}\text { Modesty (aidōs) is caution } \\
\text { about due blame. }\end{array}$ \\
\hline $\begin{array}{l}\text { Kindness (eumeneia) is lasting } \\
\text { eunoia. }\end{array}$ & $\begin{array}{l}\text { Gladness (euphrosune }) \text { is joy } \\
\text { at the deeds of the temperate. }\end{array}$ & Piety (hagneia) is caution \\
\hline $\begin{array}{l}\text { Welcoming (aspasmos) is } \\
\text { uninterrupted eunoia. }\end{array}$ & $\begin{array}{l}\text { Cheerfulness (euthumia) is } \\
\text { joy at the conduct of the }\end{array}$ & $\begin{array}{l}\text { about sins towards the } \\
\text { gods. }\end{array}$ \\
\hline Love (agapēsis) & universe. & \\
\hline
\end{tabular}

Sorabji explains that whereas joy is obviously an emotion, caution is not necessarily so. He supposes that these three species are good judgments with reasonableness involved: ${ }^{102}$ whether expansion (joy) or contraction (caution), they

\footnotetext{
99 "Augustine drew attention to the ambiguity of freedom from emotion as between a mere stupor, as he puts it, and a freedom from disturbing emotions that oppose reason, like fear and grief, as opposed to love and gladness. Many have suggested that the debate on freedom from pathos turned on an ambiguity in pathos". Sorabji 2000, 206.

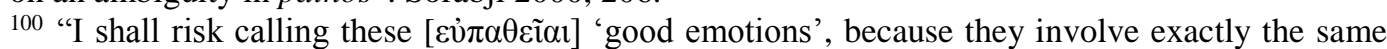
type of evaluative judgments as the ordinary person's emotions, but differ in including to false evaluations", Richard Sorabji, "Did the stoics value emotion and feeling?" in The Philosophical Quarterly (Vol. 59, 2009), 155-156. Sorabji also argues that eupatheia is to a large extent an ideal. "Because only a sage would have eupatheiai, and it is unclear whether the Stoics believe that anyone has yet attained to sagehood. It is to a large extent an ideal". Sorabji 2000, 47.

${ }_{101}$ Sorabji summaries the list of eupatheia from Andronicus' On Emotions 6 (the three generic kinds), Diogenes Laertius Vitae. 7.116, and Cicero Tusc. 4.12-13 and adds the definition of agapesis from Clement of Alexandria Stromateis 2, ch. 9, sec. 42. He also relates this in his article "Did the Stoics value emotion and feeling?" See Sorabji 2000, 48 and Sorabji 2009, 156. Similar forms and relevant discussions are found in King 2012a, 15; Brennan 1998, 35.

102 "Reasonableness (eulogon) enters the definition of all three kinds of eupatheia. Joy is a reasonable expansion, will is a reasonable desire (orexis), in other words a reasonable impulse or assent, and caution a reasonable disinclination (ekklisis, Latin declinatio)". Sorabji 2000, 48.
} 
are all reasonable, appropriate and stable, which also explains why Cicero uses the Latin word constantiae for the Greek eupatheiai. ${ }^{103}$ Sorabji adds that Plutarch states that caution is merely an ordinary emotion of fear; therefore, there are some eupatheiai that we could call emotions. In addition, Augustine is influenced by Cicero's usage of constantiae and some Stoic accounts that several eupatheiai are emotions because they are rational judgements as well as ordinary passions. Thus, he is easily led to make an incorrect evaluation that no substantial differences exist between eupatheiai and ordinary passions. To Sorabji, it is true that both eupatheia and pathos may be rational judgements, but Augustine formulates a blind equation. In fact, eupatheiai are true and good judgements that only belong to the sage, whereas pathos are false judgments that the fool always share. ${ }^{104}$ Even though eupatheia and pathos are both value judgements of the mind, their characters and inclinations are radically distinguished. Augustine mistakes the good judgements of eupatheia as false judgments such as ordinary passions, which obscures the essence between them and leads to misunderstanding. Secondly, Sorabji argues that Augustine mistakenly extends all eupatheiai to common emotions, while not considering that many eupatheiai are good states and feelings. ${ }^{105}$ Referring to the Stoic list of eupatheiai, Sorabji explains that some of them are ordinary emotions, but there are not many of them, because for the Stoics, eupatheiai are ideal. ${ }^{106} \mathrm{~A}$ part of Augustine's misinterpretation involves his increasing the proportion of ordinary emotions in eupatheiai.

More to the point, Sorabji argues, is that Augustine misrepresents the Stoic eupatheia as indifference. Sorabji defends his argument by interpreting the meaning of eupatheia: Firstly, eupatheia includes some impulses, but not necessarily the fully controlled state of apatheia. ${ }^{107}$ Rather than stupor, they are

\footnotetext{
103 Sorabji 2000, 49.

104 After introducing the reasonable character of three species of eupatheia, Sorabji adds: "In Chrysippus' view, I think a still more basic difference will have been that the judgements [eupatheia] are true, whereas, for reasons I shall explain in Chapter 12, the judgements involved in emotion are thought to be false". Moreover, eupatheia as true rational judgements can also avoid the disobedience assailing the reason. See Sorabji 2000, 49.

105 "First and foremost are the good states of feeling (eupatheiai) which only the sage has". Ibid., 47. 106 "But I believe these exceptions are few, first because the two fullest Stoic lists of eupatheiai, which very nearly agree with each other, recognize only a very few types, and secondly, because only a sage would have eupatheiai, and it is unclear whether the Stoics believe that anyone has yet attained to sagehood. It is to a large extent an ideal". Ibid., 47.

107 "Moreover, the Stoic sage not only welcomes good character in others, but also wishes it for others, and so wishes something not under his control". Ibid., 51. Sorabji accepts Inwood's account
} 
natural psychological reactions. Secondly, eupatheia is closely connected to virtuous actions, not only to an ideal mentality. Eupatheia develop from genuine good action rather than indifference. ${ }^{108}$ Therefore, Sorabji surmises that Augustine does not grasp the good character of the Stoic eupatheia, which is connected to virtues and good actions rather than bad emotions or actions. As a consequence, Sorabji believes that Augustine substantially misunderstands the term of eupatheia as well as the Stoic ideal of freedom from emotions.

Sorabji credits his position on eupatheia to Brad Inwood and Tad Brennan, scholars who both hold that eupatheia by no means implies indifference in the Stoics. Inwood suggests the slogan of "apatheia is eupatheia" with eupatheia not only referring to rational impulses, but also to the ideal psychology of action. ${ }^{109}$ Inwood considers both eupatheia and apatheia to be closely connected to virtuous behaviour. ${ }^{110}$ Brennan supports Inwood's argument and states the following: "Inwood correctly draws the line; the eupatheia is only for genuine goods. An impulse towards an indifferent, whether accompanied by reservation or not, cannot be a eupatheia". ${ }^{111}$ Brennan therefore firmly concludes that the Stoic notion of eupatheia cannot be directed to an indifferent attitude, but it is a calm pleasure about the good state of the cosmos and the virtues of oneself and others, a calm volition for these, and a calm disinclination to vice. ${ }^{112}$ Inwood and Brennan also share the interpretation that eupatheia is about genuine good things, which could be expressed as impulses, emotional states or virtuous actions, but it cannot refer to indifferent things. In other words, interpreting eupatheia as stupor or indifference, as Augustine does, is not in accordance with Stoic teachings.

on this point, who presupposes that eupatheia is the impulse of the wise. "For the proper understanding of the Stoic ideal of the freedom from passions...makes it clear that an eupatheia is simply the impulse of a fully rational man". Brad Inwood, Ethics and Human Action in Early Stoicism (Oxford: Clarendon Press, 1985), 173.

108 Sorabji maintains that eupatheia has good character and the wise will benefit from each other through it. "Eupatheia may play a role in another context, because the Stoics say that all wise people benefit (ophelein) each other, even if they do not know each other at all... he welcomes it merely in so far as he believes it exists, and wishes it merely with the reservation 'if nothing prevents', a reservation more frequently applied to preferred indifferents". Sorabji 2000, 50-51.

109 "Freedom from passions is, I have argued, closely linked to consistency in one's assents and actions...both apatheia and eupatheia as ideals for living the life of a naturally rational animal". Inwood 1985, 173.

110 "The identity of apatheia and eupatheia is also reinforced by the close connection of both to virtuous activity". Ibid., 173.

111 Brennan 1998, 56.

112 Brennan 1998, 57 and 69 (n. 98). 
In contrast to the above-mentioned argument, Peter King and Gerd Van Riel interpret Augustine's deviation from the Stoic doctrine as "reinterpretation" rather than "misinterpretation", but they defend this position differently. Peter King maintains that Augustine reconstructs the Stoic idea of eupatheia to some degree, even though he does not provide precise descriptions. ${ }^{113}$ King argues that Augustine's accounts of apatheia represent a misreading, ${ }^{114}$ but he retains the Stoic ideal state of dispassionate passions and attaches that emotional state to the afterlife in Heaven rather than to this life. King further describes the characters of these types of dispassionate passions in Heaven as follows: a) they are not disorderly passions; b) they cannot be attained in this life; c) elation and love are radically different from those in this life, as they are towards eternal and reliable object. ${ }^{115}$ These features serve as evidence that Augustine's own eupatheia is a reinterpretation that shifts the Stoic account of this life's eupatheia to the afterlife because Augustine realises that the suffering and transient happiness of this world are not relevant to an eternal ethical ideal.

Van Riel defends this "reinterpretation" from another angle. He points out that Augustine's conception of eupatheia echoes Aristotelian views rather than the Stoic doctrine, but that Augustine only adopts the Stoic terminology. ${ }^{116}$ Van Riel maintains that Augustine's "reinterpretation" is based on his "Aristotelian" position and not on a misunderstanding. Van Riel cites several reasons for his position: 1) Augustine's psychology of passions is based on the Aristotelian threefold division of the soul rather than Chrysippus' theory of unitary soul, this being the rational for Augustine equating eupatheia with pathos ${ }^{117}$ 2) Augustine prefers the therapy of moderation because he considers the Stoic ideal of apatheia and eupatheia to be unattainable in this life owing to our sinful state; ${ }^{118}$ and 3) Two passions remain for

\footnotetext{
113 "Assessing the degree to which Augustine is successful in forging a theory of dispassionate passions isn't easy, since he does not usually give precise accounts or technical details". King 2012a, 21.

${ }^{114}$ King 2012a, 14 (n. 18).

115 "Augustine insists that the presence of an assured eternal loving relationship would in fact transform the emotions into something that is calm and settled, or, in a word, dispassionate; he is arguably correct". Ibid., 21.

116 "It is important to note that Augustine here actually departs from the Stoic doctrine of $\varepsilon \cup ̉ \pi \alpha ́ \theta \varepsilon i \alpha \ldots$..As a matter of fact, Augustine's reinterpretation is not Stoic at all any more. Rather, Augustine's viewpoint is in line with that of Aristotle, though expressed in a Stoic terminology". Van Riel 2004, 522.

117 Van Riel 2004, 523-524.

118 Ibid., 524.
} 
the afterlife, gaudium and amor, which confirms that Augustine accepts the Aristotelian definition of pleasure. ${ }^{119}$ Thus, Van Riel maintains that Augustine departs from the Stoic idea of eupatheia and adopts ${ }^{120}$ the Aristotelian definition of gaudium with slight modifications. This is not only reflected on the psychological level in this life, but also on the redemptive level in the afterlife.

Although Sorabji, Inwood and Brennan propose different explications of the term eupatheia, such as an impulse of a fully rational man, a rational affect, a good state towards what is genuinely good, or an ideal state with a proportion of ordinary passions, they concur that indifference should be entirely excluded from the Stoic eupatheia. Thus, Augustine makes a radical error in equating eupatheia with stupor. However, King and Van Riel argue that Augustine retains the Stoic ideal of eupatheia as a type of dispassionate passion or freedom from emotions on another level and that his interpretation is reinterpretation instead of misinterpretation. I shall now turn to the Stoic definition of eupatheia in order to ascertain whether eupatheia is strictly separated from pathos and whether the Stoic eupatheia could be regarded as being indifference.

The above Stoic list of eupatheia consists of three generic forms with

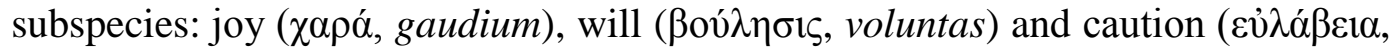
cautio). In Tusc. 4.6.11-14, Cicero provides a general account of Zeno's definition of pathos and the Stoic eupatheiai as well as their subspecies. Cicero considers pathos to be an agitation of the soul that is alien to reason and contrary to nature, ${ }^{121}$ whereas eupatheia is a rational state representing a tranquil and equable

119 "We can conclude that when Augustine transposes pleasure to the state of the redeemed body, he is doing the same as the pagan Neo-Platonists: he follows Aristotle rather than Plato. The notion of gaudium rests on the Aristotelian definition of pleasure as the supplementary effect of an unimpeded activity, namely, of the perfect activity of the will that has attained its final goal". Ibid., 530-531.

120 Van Riel uses the term "takes over" in order to emphasize Augustine's close doctrinal relationship to Neoplatonism and he maintains that Augustine follows the Aristotelian definition of contentment in forming his theological concept of eupatheia, namely, frui Deo. It is noteworthy that when Van Riel claims that Augustine is in line with the "Platonic-Peripatetic" position rather than the Stoic one, he does not strictly distinguish between the terms "Neo-Platonic" and "Platonic-Peripatetic". He refers to the general frame of "Platonic-Peripatetic position" using the term "Neo-Platonic": "when Augustine takes over the Neo-Platonic definition of pleasure...This is in line with the overall definition of pleasure as the transition towards a state of contentment", "he [Augustine] follows Aristotle rather than Plato...That is what makes voluptas different in kind from gaudium, or from frui Deo". See Van Riel 2004, 529 and 531.

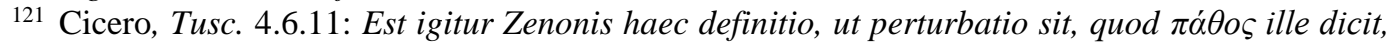
aversa a recta ratione contra naturam animi commotio. Quidam brevius perturbationem esse appetitum vehementiorem, sed vehementiorem eum volunt esse, qui longius discesserit a naturae constantia. Similar thoughts can be found in Diogenes Laertius, Vitae philosophorum 7.110; 
way of life that only the wise enjoy. The passions are divided according to whether the object, good or evil, occurs in the present or future: delight (laetitia: present good), desire (libido: future good), distress (aegritudo: present evil) and fear (metus: future evil). Eupatheia can be divided in an analogous way, but without an analogue to distress: joy (gaudium: present good), wish (voluntas: future good), and caution (cautio: future evil). ${ }^{122}$ Similar statements are also made in Pseudo-Andronicus (Stoicorum Veterum Fragmenta 3.391; 3.432), Diogenes Laertius (Vitae. 7.111-116), and Stobaeus (Eclogae 2.90.7-8). ${ }^{123}$ Cicero summarizes the classical Stoic theory of pathos and eupatheia and outlines their subspecies in his Tusc. 4.6.11-14 as follows:

\begin{tabular}{|l|l|c|l|}
\hline \multicolumn{2}{|c|}{ Eupatheia } & \multicolumn{1}{c|}{ Pathos } \\
\hline $\begin{array}{l}\text { Wish } \\
\text { (will) }\end{array}$ & $\begin{array}{l}\text { Wish is a rational longing for good } \\
\text { things }^{124}\end{array}$ & Desire & $\begin{array}{l}\text { Alien from reason, too violently } \\
\text { aroused and unbridled }^{125}\end{array}$ \\
\hline Joy & $\begin{array}{l}\text { Joy is a rational satisfaction of the } \\
\text { soul that is tranquil and equable }\end{array}$ & Delight & $\begin{array}{l}\text { Exuberant, irrational excitement } \\
\text { of the soul }^{127}\end{array}$ \\
\hline Caution & $\begin{array}{l}\text { Rational desire for good in avoidance } \\
\text { from evil }\end{array}$ & Fear & $\begin{array}{l}\text { Alien from reason and associated } \\
\text { with abject timidity }^{129}\end{array}$ \\
\hline- & & Distress & $\begin{array}{l}\text { Being downcast and shrunken in } \\
\text { disobedience to reason }\end{array}$ \\
\hline
\end{tabular}

It is not difficult to determine that eupatheia refers to a rational contraction or expansion of the soul in accordance with virtues, whereas pathos refers to an

Stobaeus, Eclogae 2 (88.8-11); Galen, De placitis Hippocratis et Platonis 4.2.8. For the irrationality of the passions in Stoicism, see Sorabji 2000, 29-54.

122 Cicero explains that distress is a contraction of the soul that is in conflict with reason; therefore, there is no rational counterpart to this present evil in a sage's soul. Tusc. 4.6.14: Itaque haec prima definitio est, ut aegritudo sit animi adversante ratione contractio. Sic quattuor perturbationes sunt, tres constantiae, quoniam aegritudini nulla constantia opponitur.

${ }^{123}$ See King 2012a, 11 (n. 7) and 15 (n. 20).

124 Tusc. 4.6.12: quod bonum videatur, ad id adipiscendum impellit ipsa natura. Id cum constanter

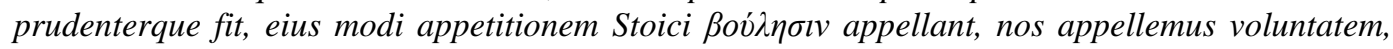
eam illi putant in solo esse sapiente; quam sic definiunt: voluntas est, quae quid cum ratione desiderat. A similar definition in Diogenes Laertius Vitae. 7.116.

${ }^{125}$ Tusc. 4.6.12: Quae autem a ratione adversa incitata est vehementius, ea libido est vel cupiditas effrenata, quae in omnibus stultis invenitur.

${ }^{126}$ Tusc. 4.6.13: Itemque cum ita movemur, ut in bono simus aliquo, dupliciter id contingit: nam cum ratione animus movetur placide atque constanter, tum illud gaudium dicitur.

127 Tusc. 4.6.13: Cum autem inaniter et effuse animus exsultat, tum illa laetitia gestiens vel nimia dici potest, quam ita definiunt: sine ratione animi elationem.

128 Tusc. 4.6.13: Quoniamque, ut bona natura appetimus, sic a malis natura declinamus, quae declinatio cum ratione fiet, cautio appelletur, eaque intellegatur in solo esse sapiente.

${ }^{129}$ Tusc. 4.6.13-14: Quae autem sine ratione et cum exanimatione humili atque fracta, nominetur metus: est igitur metus a ratione aversa cautio.

${ }^{130}$ Tusc. 4.6.14: Stultorum aegritudo est, eaque adficiuntur in malis opinatis animosque demittunt et contrahunt rationi non obtemperantes. 
irrational agitation of the soul and appears as an excessive and disobedient psychic movement. In addition to this, some noteworthy similarities and dissimilarities are evident between eupatheia and pathos, which could be summarised as follows:

1. Some eupatheiai and pathe might pertain to the same object and share some characteristics. For example, joy (gaudium) and delight (laetitia) both constitute an expansion of the soul, but it is difficult to evaluate the boundary between them from this vantage point, even though they remain distinct in Stoicism. Their difference is that joy is a rational impulse that leads to a tranquil satisfaction based on the knowledge that assuming this attitude is good, whereas delight is an excessive impulse that is alien to reasonableness and based on a false opinion of the value of the object and action. If both are happy in obtaining food when they are hungry, the joy of those who are wise includes an evaluative thinking regarding the goodness of the natural order and that of the fool involves the fulfillment of his self-centred desire. It seems that the same object is conceptualised in different ways. If an emotional person also feels happy because nature is good in offering food, that reaction may also be a passion in the sense that the evaluation is not derived from the Stoic worldview, even though it overlaps to some extent, but this means nonetheless that it is not rational. This suggests that the difference is less clear than it might seem to be.

2. A significant standard for judging whether something constitutes a eupatheia is reasonableness. Reasonableness implies that all the impulses of the soul direct one toward the good within the framework of right reason. As long as the impulse is reasonable, the action is not "excessive" or improper. However, if the evaluation is false and unreasonable, the resulting action is typically excessive and unhealthy. Yet this line of reasoning is not very convincing. Even though the Stoics contend that only the first thought is rational, the question remains as to why the Stoics' joy for the good order in the world should be calmer than the Christians' joy of it as a work of Creation.

3. In the above list, all three types of eupatheia are associated with a tranquil and constant mind without excessive reactions; viewed from the outside, these people may appear to be indifferent to events that occur in everyday life. In this sense, the word "indifference" can be a slanderous or negative description of 
a tranquil state of mind. The Stoics explain that the eupatheiai are directed to the good and support activities in accordance with the good and those who avoid evil. What is not included in these categories is the ethically indifferent, but the behaviour regarding indifferent matters can also be based on choices and preferences. These are not morally relevant and are indifferent in this sense, but they are not indifferent as part of everyday life. ${ }^{131}$ The sages' attitudes are focused on the genuine good, which is defined as virtues in accordance with the divine reason guiding reality. This involves a correct attitude towards indifferent things. ${ }^{132}$ While Nussbaum envisions the eupatheiai as correct impulses to external indifferents, Brennan maintains that they are only directed to genuine good and evil and these do not include indifferents. ${ }^{133}$ What is the difference here? Nussbaum asserts that the Stoic wise correctly differentiate what is indifferent and this is part of the eupatheia attitude, whereas Brennan argues that eupatheia is directed at virtuous behaviour involving a correct attitude toward indifferent matters. I do not discern any profound difference here. The Stoics emphasise that it is a mistake to regard indifferent things as being very valuable and the Stoics recognise them as indifferent due to their correct value orientation. It is part of the Stoic theory that passions are false beliefs that interpret indifferent things as being highly important to the subject. It is this self-centred evaluation that the Stoics reject, claiming that the objects of passions are indifferent. This detachment does not mean that in some cases, a wise choice that is based on moral knowledge could not be the same as an emotional choice. The argument is that a wise choice is made without having emotional commitments to particular things.

It is noteworthy that the sage bases his indifference on good judgements of the mind and this leads to virtuous actions. This does not imply that the sage would not have preferences between morally indifferent things, such as choosing foods. However, in contrast, the fool's choices are based on false judgements that are evident in his having unbalanced passions and evil behaviours. They may also

\footnotetext{
131 See Brennan 1998, 61-62.

132 Nussbaum 1994, 399; Brennan 1998, 55-56.

133 Brennan argues that "unfortunately, her [Nussbaum] comments about the eupatheiai are incorrect. She rightly observes that they 'are not passions and are not identified with any high evaluation of externals.' But she takes them instead to be correct, non-excessive, impulses to external indifferents...That is not correct...In no case is a eupatheia directed towards an indifferent, and in several cases it is directed towards a genuine good...The eupatheiai are thus all directed at genuine goods and evils". See Brennan 1998, 54-57. Cf. Nussbaum 1994, 379, 380 and 399.
} 
be indifferent when they should not, expressing moral stupor. In this sense, indifference as a connotation of the Stoic eupatheia should be distinguished from that of indifferent fools. The former connotation is in agreement with the rational worldview, ${ }^{134}$ whereas the fool is merely conveying an irrational attitude.

Let us now turn to Augustine's texts to review his description of the Stoic eupatheia. In his early works, such as De beata uita, Contra Academicos, De ordine, De quantitate animae and De immortalitate animae, Augustine prefers to interpret constantia ${ }^{135}$ as immutability (immutabilis), as the changelessness of supreme reason. This immutability makes one achieve a state of tranquility and attain a happy life (beata vita). Augustine regards constantia as a stable and unchangeable state and holds that the human mind could be immortal if it would follow supreme good without separating from it. Furthermore, in De immortalitate animae 11.18, De beata uita 4.28 and De utilitate credendi 12.27, Augustine assents to the Stoic theory of dividing people into two groups of sages and fools, and argues that the wise enjoys a more stable and fuller being, whereas the foolish mind turns away from the supreme good and binds itself to some state of defect. In De libero arbitrio 1.13, he supports the Stoic virtues of caution, fortitude, temperance, and justice based on the contemplation of transcendent and eternal good:

(1) Quaedam constantiae uirtus est, et omnis constantia immutabilis est, et omnis uirtus potest aliquid agere, nec cum agit aliquid, uirtus non est. (De immortalitate animae $3.3)^{136}$

(2) Est enim maxime ipsa ratio, ubi summa etiam incommutabilitas intellegitur. Ita quaecumque ex se afficit, cogit esse quodammodo. Non ergo exstingui animus potest, nisi a ratione separatus; separari autem non potest, ut supra ratiocinati sumus: non potest igitur interire. At enim aversio ipsa a ratione per quam stultitia contingit animo, sine defectu eius fieri non potest. (De immortalitate animae 6.11-7.12) (37 $^{137}$

\footnotetext{
${ }^{134}$ I combine the Stoic indifference with the "rational worldview". The Stoic eupatheia represents impassibility and tranquility with respect to particular things. Because eupatheia means that one does not have passions, it may give rise to a behaviour similar to that of ordinary people without emotions in particular situations.

${ }^{135}$ In Brepols database (Library of Latin Texts), the word constantia occurs 36 times and constantiae 10 times in Augustine's works, and constantias twice in De civitate Dei.

136 "Constancy possesses some power, and all that is constant is not subject to change. Every power is able to perform some act, being a power even when not in action". [transl. Ludwig Schopp]

137 "And reason [the true] itself is there in the highest degree where changelessness is conceived in 
(3) Tamen etiam hoc attendendum est, non esse aliam causam huius formidinis, nisi quia fatendum est in defectu quodam esse animum stultum, et in essentia certiore atque pleniore sapientem. Sed si, quod nemini dubium est, tunc est animus sapientissimus, cum veritatem, quae semper eodem modo est, intuetur, eique immobilis inhaeret divino amore coniunctus. (De immortalitate animae 11.18) $)^{138}$

(4) Uiximus enim magna mentis tranquillitate ab omni corporis labe animum uindicantes et a cupiditatium facibus longissime remoti, dantes, quantum homini licet, operam rationi, hoc est secundum diuinam illam partem animi uiuentes, quam beatam esse uitam hesterna inter nos definitione conuenit. (Contra Academicos 1.4.11) $)^{139}$

(5) Est ergo animi egestas, inquam, nihil aliud, quam stultitia. Haec est enim contraria sapientiae... ut beata uita miserae, hoc est sine aliquo medio... sic omnem non stultum manifestum est esse sapientem. (De beata uita 4.28$)^{140}$

(6) ...esse prudentia adpetendarum et uitandarum rerum scientia ...fortitudo nonne illa est animae adfectio, qua omnia incommoda et damna rerum non in nostra potestate constitutarum contemnimus...porro temperantia est adfectio coercens et cohibens adpetitum ab his rebus quae turpiter adpetuntur...iustitiam quid dicamus esse nisi uirtutem, qua sua cuique tribuuntur? (De libero arbitrio 1.13$)^{141}$

In (1), Augustine explains that the literal meaning of the word constantia is immutability (immutabilis). Thus, constantia is not subject to change, but possesses power even when not acting. Augustine continues to interpret constantia

the highest degree. Therefore, reason [the true] forces the mind somehow to be, which it, from its own being, affects. Thus, without separation from reason [the true], the mind cannot be extinguished. But, a separation is impossible, as we have reasoned above. Therefore, the mind cannot perish. On the other hand, the mind cannot turn away from reason [the true] - in doing so it falls into foolishness-without suffering a defect". [transl. Ludwig Schopp]

138 "Nevertheless, attention should be paid to the point that the only cause for fear lies in the undeniable fact that a foolish mind is in some state of defect, while the wise enjoys a more stable and fuller being. But if, as cannot be doubted, the mind is then most wise when it sees the truth that is always and without change, and, joined by a divine love, inheres in the truth immovably". [transl. Ludwig Schopp]

139 "We lived in great mental tranquility, keeping the spirit free from every stain of the body; and, far removed from the raging flames of desire, we were taking pains, as far as man is allowed, to cultivate reason - that is, to live according to the divine part of the spirit - and this we agreed yesterday was by definition the happy life". [transl. Peter King]

140 "Consequently, the want of the soul is nothing but foolishness, I said, it is the opposite of wisdom...a happy life is the opposite of a miserable one, that is, without a middle state...every man who is not foolish is wise". [transl. Ludwig Schopp] For a similar statement see also util. cred. 12.27: porro recta ratio est ipsa uirtus... Solus igitur sapiens non peccat. Stultus ergo omnis peccat, nisi in iis factis, in quibus sapienti obtemperauerit.

141 "[Prudence] is the knowledge of what we should seek and avoid...Fortitude is a disposition of the soul by which we shun all inappropriate and miserable things that are not in our power...Temperance is the disposition that constrains or impedes our desire for those things which are wrongfully desired...Justice is the virtue which renders to each his own". [transl. Colish] Colish 1985 (II), 215. 
as the changelessness (incommutabilitas) of reason that is not affected by the outside and it is imperishable (2). Thus, the soul will be in a stable state and cannot be extinguished if it is united with the immutable reason without separation, and a separation is impossible. Augustine emphasises that only when the principle of constantia connects with the mind will the wise enjoy a stable and full being, being inherent in the truth immovably. Furthermore, turning away from reason is foolishness and a self-imposed defect (3). Augustine attempts to connect the value of constantia to a happy life and to regard it as the standard for distinguishing between the sage and the fool, keeping to the nature of the mind, or being defective in this respect $(3,5)$. To Augustine, it is important that the wise enjoy a tranquil and stable life without the disturbance created by emotions, while fools are emotionally upset, there being no middle condition between the sage and the fool. It is essential to note here that Augustine's argument is consistent with the Stoic cosmic view of the immutable reason and natural order. ${ }^{142}$ The non-rational motion of the mind breaks the static and balanced structure of the soul and makes it uncertain and disordered, far from the perfect state of constantia. This is the cause of the fool's miserable life. Therefore, in (4) and (6) Augustine highlights the state of tranquility in terms of the Stoic four virtues derived from an understanding of the genuine good. Augustine's interpretation of the Stoic doctrine stresses two points, genuine good and impassibility, which is obviously in line with the Stoic teaching of eupatheia.

However, in City of God 14.8, Augustine changes his previous tone and some of his illustrations appear different:

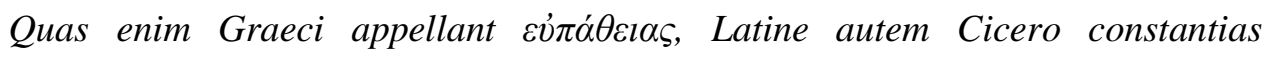
nominauit, Stoici tres esse uoluerunt pro tribus perturbationibus in animo sapientis, pro cupiditate uoluntatem, pro laetitia gaudium, pro metu cautionem; pro aegritudine uero uel dolore, quam nos uitandae ambiguitatis gratia tristitiam maluimus dicere, negauerunt esse posse aliquid in animo sapientis. Uoluntas quippe, inquiunt, appetit bonum, quod facit sapiens; gaudium de bono adepto est,

\footnotetext{
142 Miikka Ruokanen provides evidence that Augustine's doctrine of ordo naturae is in line with the Platonic concept of the eternal and immutable reason, lex aeterna or lex naturalis. (Ruokanen 1993, 29-31). This might well be so, but I would like to add that, from the point of the constantia that Augustine discusses in his early works, he is also inclined to the Stoic teaching of nature in dealing with the correlation between the tranquil mind and the constantia nature of the supreme good in the cosmos.
} 
quod ubique adipiscitur sapiens; cautio deuitat malum, quod debet sapiens deuitare; tristitia porro quia de malo est, quod iam accidit, nullum autem malum existimant posse accidere sapienti, nihil in eius animo pro illa esse posse dixerunt. Sic ergo illi loquuntur, ut uelle gaudere cauere negent nisi sapientem; stultum autem non nisi cupere laetari, metuere contristari; et illas tres esse constantias, has autem quattuor perturbationes secundum Ciceronem, secundum autem plurimos passiones. Graece autem illae tres, sicut dixi, appellantur $\varepsilon \dot{\pi} \pi \alpha \theta \varepsilon i \tilde{\alpha l}$, istae autem quattuor $\pi \alpha \dot{\theta} \theta \eta^{143}$

This description by Augustine closely follows Cicero's account and correctly presents the Stoic teaching of eupatheia. Augustine repeats his earlier account that the three subspecies of eupatheia are directed towards the genuine good, which only the wise possesses, whereas passions are perturbations that only belong to the fool. In the next text, Augustine begins to doubt the above argument by citing the Bible: "There is no gladness, saith my God, to the wicked" (Non est gaudere impiis, dicit Dominus), "On earth peace, good will toward men" (Pax in terra hominibus bonae voluntatis). He inquires here that if the will (voluntas) only refers to "good" will, why add the redundant word "good"? (Nam ex abundanti additum est “bonae", si esse non potest nisi bona). ${ }^{144}$ Augustine also refers to some secular authors who offer examples, in which some apparent eupatheiai (such as gaudium) are associated with an evil sense and passions (for example, cupio) with a good sense:

\footnotetext{
${ }^{143} C D$ 14.8: "In place of three of the disturbances of the mind discussed above, the Stoics wish to find in the mind of the wise man three dispositions, called eupatheiai in Greek, and in Latin, by Cicero, constantiae. Instead of desire they find will; instead of joy, gladness; instead of fear, caution. They deny, however, that there can exist in the wise man's mind anything corresponding to distress or pain, which, to avoid ambiguity, I have preferred to call grief. The will, say the Stoics, certainly pursues the good, and this is what the wise man does; gladness arises from the attainment of the good, which the wise man attains wherever he may be; and caution avoids evil, which is what the wise man ought to avoid. Grief, however, is occasioned by an evil which has already happened; and since, as they think, no evil can befall a wise man, they say that there can be nothing corresponding to grief in the wise man's mind. What they say, then, amounts to this: that only the wise man can have will, gladness and caution, whereas the fool can experience nothing save desire, joy, fear and grief. The three former are constantiae, while the latter four are 'disturbances' according to Cicero, but 'passions' according to most other authors. In Greek, however, as I have said, the three former are called eupatheiai; and the four latter are called pathé".

144 CD 14.8: Haec locutio utrum scripturis sanctis congruat, cum quaererem quantum potui diligenter, illud inueni quod ait propheta: Non est gaudere impiis, dicit Dominus...Locutione uero usitatiore, quam frequentat maxime consuetudo sermonis, non utique diceretur: Noli uelle mentiri omne mendacium, nisi esset et uoluntas mala, a cuius prauitate illa distinguitur, quam praedicauerunt angeli dicentes: Pax in terra hominibus bonae uoluntatis. Nam ex abundanti additum est "bonae", si esse non potest nisi bona.
} 
Et apud auctores saecularium litterarum talis istorum uerborum indifferentia reperitur. Ait enim Cicero orator amplissimus: "Cupio, patres conscripti, me esse clementem". Quia id uerbum in bono posuit...Porro apud Terentium flagitiosus adulescens insana flagrans cupidine: Nihil uolo aliud, inquit, nisi philumenam. Quam uoluntatem fuisse libidinem responsio...Gaudium uero eos et in malo posuisse ille ipse Uergilianus testis est uersus, ubi has quattuor perturbationes summa breuitate complexus est: Hinc metuunt cupiuntque, dolent gaudentque. Dixit etiam idem auctor: Mala mentis gaudia. ${ }^{145}$

After listing the evil sense of the eupatheia terms in Cicero, Virgil and other secular authors, Augustine concludes as follows:

Proinde uolunt cauent gaudent et boni et mali; atque ut eadem aliis uerbis enuntiemus, cupiunt timent laetantur et boni et mali; Sed illi bene, isti male, sicut hominibus seu recta seu peruersa uoluntas est. Ipsa quoque tristitia, pro qua Stoici nihil in animo sapientis inueniri posse putauerunt, reperitur in bono et maxime apud nostros. ${ }^{146}$

This claim is no longer in accordance with the Stoics. Augustine therefore offers the following arguments:

(1) Three types of eupatheia (will, caution and gladness) as well as four forms of passio can be either good or bad and can belong to a good or evil man.

(2) Grief, as a type of passion, can also be found in the mind of the wise.

(3) Passions of the soul in Christians are righteous and good; whereas the true tranquility of the Stoics is inhuman, pride, stupor and unhealthy. ${ }^{147}$

\footnotetext{
$145 C D$ 14.8: "Such an indiscriminate use of these terms is seen also among authors of secular literature. For Cicero, a most distinguished orator, says, 'I desire, conscript fathers, to be merciful.' He here uses the word 'desire' in a good sense... On the other hand, in Terence's play, there is the disgraceful young man who, mad with the heat of his own lust, says, 'I have a will for naught but Philumena.' But his 'will' was his desire...'gladness' is used in a bad sense in that same line of Virgil which contains his most brief statement of the four things which disturb the mind: 'Hence come desire and fear, gladness and sorrow.' The same author also speaks of 'The evil gladness of the mind"”.

${ }^{146} C D$ 14.8: "Will, caution and gladness, then, are common to both good and evil men; and - to make the same point in different words - good and evil men alike feel desire, fear and joy. But the good feel these emotions in a good way, and the bad feel them in a bad way, just as the will of men may be righteous or perverse. Also, although the Stoics find nothing in the mind of the wise man corresponding to grief, we discover that even this is used in a good sense, and especially in our own Scriptures".

147 CD 14.9: ...ciues sanctae ciuitatis Dei in huius uitae peregrinatione secundum Deum uiuentes metuunt cupiunt que dolent gaudent que et quia rectus est amor eorum, istas omnes affectiones rectas habent...Et si nonnulli tanto inmaniore, quanto rariore uanitate hoc in se ipsis adamauerint, ut nullo prorsus erigantur et excitentur, nullo flectantur atque inclinentur affectu: humanitatem totam potius amittunt, quam ueram adsequuntur tranquillitatem. Non enim quia durum aliquid, ideo rectum, aut quia stupidum est, ideo sanum. (“...citizens of the Holy City of God live according to 
The first point (1) obviously violates the basic Stoic principle as we have observed: a eupatheia is only directed to the genuine good and an avoidance of evil things; a eupatheia can neither be bad nor can it belong to an evil man. Equating eupatheia with passio, Augustine counters his own previous interpretation. Grief is a passion (2) that breaks the perfect and balanced order of the soul and even makes life miserable and bad. This, of course, is not attributed to the wise in the Stoic doctrine, but Augustine states that grief can occur in the mind of the wise. In addition, in (3), Augustine refers to the Stoic tranquility of the mind as inhuman and stupor, which contradicts his previous proposition. Hence, if we are limited to this pericope here, it seems correct to suppose that Augustine actually misinterprets the Stoic eupatheia, as Sorabji does. However, Augustine adds the following points in CD 14.9 to delve deeper into the concept of eupatheia and attempts to make the above arguments reasonable and thought-provoking:

1. Both the wise and the fool have the same psychological structure and the controlling instance of their soul is the same, the will (voluntas), which decides about the behavioural impulses of the soul; in other words, the deciding power with respect to eupatheiai and passions is the will (voluntas). Therefore, a eupatheia or a pathos can be either good or bad and can belong to good or to an evil man.

2. If passions derive from the love of the good or from the holy charity, in proper time and occasions, they are good and reasonable rather than evil. ${ }^{148}$ Therefore, an eligible grief can be found in the mind of the wise.

3. Impassibility is good and worthy to be willed. If we want to live a happy life, an everlasting, tranquil and immutable mind is desirable and necessary. This happy condition has been promised to the citizens of the City of God who are living in this pilgrimage towards the eternal blessed tranquility of love, but this true tranquility and impassibility cannot be completely attained in the fallen state. What

God during the pilgrimage of this present life. Such citizens feel fear and desire, pain and gladness, but in a manner consistent with the Holy Scriptures and wholesome doctrine; and because their love is righteous, all these emotions are righteous in them...Some of these [like the Stoics], with a vanity as monstrous as it is rare, are so entranced by their own self-restraint that they are not stirred or excited or swayed or influenced by any emotions at all. But these rather suffer an entire loss of their humanity than achieve a true tranquility. For a thing is not right merely because it is harsh, nor is stolidity the same thing as health".)

${ }^{148}$ CD 14.9: Hi motus, hi affectus de amore boni et de sancta caritate uenientes si uitia uocanda sunt, sinamus, ut ea, quae uere uitia sunt, uirtutes uocentur. Sed cum rectam rationem sequantur istae affectiones, quando ubi oportet adhibentur, quis eas tunc morbos seu uitiosas passiones audeat dicere? 
is more, on specific occasions, impassibility without caritas is stupor, inhuman and vicious and should be avoided. ${ }^{149}$

It is evident that Augustine's additional remarks remain connected to the Stoic features of eupatheia, clinging to genuine good and reasonableness, but he emphasises that the key factor in determining the character of eupatheia and pathos is the human will. For this reason, the Stoic eupatheia is an ideal condition that will be attained not in this life, but in the future after the redemption. Augustine appreciates the Stoic impassibility and tranquility of mind in his early years, but later he turns to presuppose that such a perfect state cannot be attained under the conditions of the present life and maintains that the essence of the Stoic doctrine of eupatheia is a mistaken attempt to locate perfection in the fallen world. Augustine suggests that it is better for the earthly citizens to have righteous passions during this pilgrimage life and then to progress to the eternal immortality of eupatheia in the blessed future. His additions indicate that he understands the Stoic definition of eupatheia and wants to point out the weakness of their argumentation on this concept. Augustine evaluates the Stoic ideal in a theological domain. Thus, once again his controversial arguments in $C D$ 14.8-9 are considered, representing his mature thinking on the issue of the Stoic eupatheia.

\subsection{Augustine's Consideration of the Therapy of Passions}

Thus far I have traced Augustine's thoughts in his early, middle, and late works on a series of concepts related to his moderation and control of passions, and have noticed that he has controversial formulations in his late pivotal work De civitate $D e i$, and that the controversy is linked to his attempt to shift the scope of discussions to a theological context. Besides those critics who argue that these problems are based on Augustine's misunderstandings, there is an alternative interpretation of them. Some scholars maintain that in Augustine's theological

${ }^{149}$ CD 14.9: ...quae si Latine posset inpassibilitas diceretur ...bona plane et maxime optanda est, sed nec ipsa huius est uitae... cum animum contingere omnino non potest ullus affectus, quis hunc stuporem non omnibus uitiis iudicet esse peiorem?...auersanda est in hac uita, si recte, hoc est secundum Deum, uiuere uolumus; in illa uero beata, quae sempiterna promittitur, plane speranda est. Augustine displays a complicated attitude toward impassibilitas in the mundane life, rather than simply refuting it on all occasions. What he does not accept is the impassibility without caritas as well as the perpetual apatheia, which he considers to be impossible. I will analyse the details at the level of social life in the next chapter. 
context, some "inconsistencies" confirm that he has deviated from the Stoic doctrine entirely. Others propose the contrary view that Augustine's aim is in line with the Stoics or the Platonists since he retains their goal of freedom from passions (apatheia and eupatheia) without leaving their doctrinal frameworks completely. I shall evaluate the different positions on the issue of whether philosophical traditions have been retained in Augustine's new treatment of the passions.

Gerard O'Daly argues that in Augustine's late work De civitate Dei, he does not accept the Stoic ideal of freedom from passions (apatheia) neither in the earthly city nor in the Heavenly City. ${ }^{150}$ As for the earthly city, O'Daly maintains that Augustine does not distinguish passions from constantiae (O'Daly uses the term "the stable states") nor does he differentiate good emotions themselves from bad, since they may be either good or bad according to whether the will is good or bad. Moreover, Christians should have appropriate passions and "fear eternal punishment, desire eternal life, fear to commit sin, and to feel pain over sins committed", the emotion of "fear" and "desire" showing a righteous and appropriate sense. ${ }^{151}$ Augustine does not adopt the Stoic doctrine of passions that associates emotions with diseases or evils, but thinks that freedom from emotion in the mundane life is inhumanity and insensitivity. At the level of the Heavenly City, O’Daly observes, humans can also feel some emotions, such as love and gladness, and "some emotions are not peculiar to our earthly condition". ${ }^{152}$ O'Daly states that Augustine provides a positive account of emotions and the emotions in the City of God are approved. ${ }^{153}$ Thus, Augustine also does not adopt the Stoic ideal of freedom from emotions (apatheia) at this level. On this basis, O'Daly notes that Augustine's theory is obviously distinguished from the Stoic doctrine of passions and that in his interpretation of passions, Augustine does not retain the Stoic ideal of freedom from emotion.

\footnotetext{
150 "Augustine is unimpressed by the Stoic ideal of freedom from passions ('apatheia'). He quotes Crantor from Cicero (Tusc. 3.12) in calling it mental inhumanity and bodily insensitivity. Augustine also finds it an unattainable ideal in this life. Moreover, in their heavenly state, the good will feel love and gladness. Some emotions are not peculiar to our earthly condition”. O'Daly 1999, 156.

151 O’Daly 1999, 155.

152 Ibid., 156.

153 "Having given such a positive account of emotions, Augustine feels obliged to add a postscript stressing the wrecking potential of emotions misused. The emotions of the denizens of the city of God may be approved..." Ibid., 156. Gerd Van Riel also advocates the view that Augustine retains some passions (e.g., joy and love) in the afterlife and he thinks that Augustine is in line with the Neo-Platonic definition of pleasure. See Van Riel 2004, 524-531.
} 
Marcia Colish also advocates the position that Augustine does not adopt the Stoic view of apatheia in his late works, whereas during his early years, Augustine adheres to the Stoic position and appreciates the state of immovability and tranquility of the mind. He nonetheless revises his position on the basis of both theological and psychological grounds during the late 380s and early 390s. ${ }^{154}$ Colish contends that in Augustine's late thought, he harbours the negative belief that the Stoic goal of impassibilitas was neither present in Adam and Eve, nor is it attained in the present life. ${ }^{155}$ Colish states that Augustine presumes that Adam and Eve did not possess apatheia before the Fall; otherwise they could not have desired for the forbidden fruit. ${ }^{156}$ While apatheia is impossible in the present life, some of the passions, such a love and joy, will be also possessed eternally in the next life. ${ }^{157}$ Colish therefore concludes that the Stoic ideal of freedom from passion has been wholly removed from Augustine's late thought of passions.

Peter King makes some modifications to Colish's observations, arguing that

154 "He [Augustine] defends the possibility and desirability of apatheia in his earliest works but subsequently modifies or rejects this position on both theological and psychological grounds. This process of revision had begun by the late 380s and early 390s". Colish 1985 (II), 221.

155 "The goal of apatheia or impassibilitas...is unattainable in this life...Not even Adam and Eve before the Fall possessed apatheia, Augustine maintains, otherwise they could not have felt the desire for the forbidden fruit". Colish 1985 (II), 225.

156 Ibid., 225. Colish's statement that the first human beings did not have the psychology of apatheia before the transgression is not exact. In $C D$ 14.10, Augustine states that before sin, there was no sin in paradise and Adam and Eve were living an entirely tranquil and happy life in Eden without perturbations nor temptations. This is a psychology of contentment toward the genuine good that is in accordance with the Stoic description of apatheia. Augustine makes his point as follows: firstly, in paradise, Man lived in the enjoyment of God with an entire tranquility of soul, no want, no desire, nor the corruption of body. He lived in the genuine good (CD 14.26: Uiuebat itaque homo in paradiso sicut uolebat, quamdiu hoc uolebat quod Deus iusserat; Uiuebat fruens Deo, ex quo bono erat bonus; Uiuebat sine ulla egestate, ita semper uiuere habens in potestate... Nihil corruptionis in corpore uel ex corpore ullas molestias ullis eius sensibus ingerebat. Nullus intrinsecus morbus, nullus ictus metuebatur extrinsecus. Summa in carne sanitas, in animo tota tranquillitas). Secondly, in the process of sexual intercourse, there was no excitement of passion aroused; the first man poured seeds into his wife's womb in tranquility of mind without any corruption of her body's integrity (CD 14.26:...et sine ardoris inlecebroso stimulo cum tranquillitate animi et corporis nulla corruptione integritatis infunderetur gremio maritus uxoris). These two points illustrate that Adam and Eve had the life of apatheia in Eden before the temptation and sinful desire. Augustine notes that only when Eve was enticed to taste the forbidden fruit, the desire aroused shows the origin of sin. See CD 14.10: Si enim habebant, quo modo erant beati in illo memorabili beatitudinis loco, id est paradiso?... Amor erat inperturbatus in Deum atque inter se coniugum fida et sincera societate uiuentium...Erat deuitatio tranquilla peccati, qua manente, nullum omnino alicunde malum quod contristaret inruebat... Absit, inquam, ut ante omne peccatum iam ibi fuerit tale peccatum, ut hoc de ligno admitterent, quod de muliere Dominus ait: Si quis uiderit mulierem ad concupiscendum eam, iam moechatus est eam in corde suo.

157 "Augustine adds that, even in the state of blessedness, some of the passions, such as love and joy, will not only be retained but will also be consummated, enjoyed and possessed eternally in a perfect and perpetual security". Colish 1985 (II), 225. 
Augustine rejects the Stoic doctrine of passions except for their ideal of dispassionate passions (apatheia). However, when commenting on this notion in Augustine's late theological schema, King proposes that Augustine formulates it without adhering to the Stoics. ${ }^{158}$ King disagrees with Colish's position that after his early period, Augustine eliminates the doctrine of freedom from passions, and King states that such an ideal has been retained in Augustine for a longer time. ${ }^{159}$ But when referring to the new structure of passions in Augustine's late writings, King claims that it is difficult to estimate the degree of success in Augustine's formulation of a new theory of dispassionate passions, since Augustine has abandoned the Stoic arguments. In other words, Augustine's new theory has completely deviated from the Stoic doctrine of freedom from passions.

Contrary to the above-mentioned positions, Johannes Brachtendorf argues that Augustine is in line with the Stoic ideal of freedom from passions (apatheia) without deviation, even though Augustine and the Stoics assume different approaches to it. Brachtendorf maintains that in adopting the model of Christ's passions, Augustine is not criticising the Stoic moral psychology, but echoing their ideal of apatheia and reaching for the goal of freedom from passions. Brachtendorf states the following:

The Stoic ideal of apatheia has to be compared with what Augustine says about the state of perfection. To criticize this ideal by reference to Jesus Christ makes no sense... Through Christ's perturbationes we can regain tranquility, and through his infirmitas we become firm again. Christ's evocation of passions aims at deliberating humans from their passions. ${ }^{160}$

Brachtendorf believes that for Augustine, a necessary condition for salvation is freedom from negative passions. No one can attain Christ's degree of confronting passions in meditating and imitating Him because Christ is both a man and God who decides to deliberately experience passions as a way of therapy. Christ's life provides an unattainable therapeutic model, as does the Stoic ideal of apatheia, but

158 "Augustine rejects the Stoic account of the passions, but he retains their ideal of a state in which there are only dispassionate passions...Assessing the degree to which Augustine is successful in forging a theory of dispassionate passions isn't easy, since he does not usually give precise accounts or technical details... No need to engage the Stoic arguments; Augustine has disposed of them. And it became a part of Christian dogma that human nature, prior to Original Sin, is free of desire and fear; that in Heaven there are dispassionate passions, which, even more paradoxically than anything the Stoics came up with". King 2012a, 21-22.

159 "Colish...maintains that Augustine abandoned the ideal of passionlessness after this early period. I disagree, as will be evident shortly”. King 2012a, 20 (n. 34).

160 Brachtendorf 1997, 304. 
Christ's model is embedded in a different salvific narrative. ${ }^{161}$ Thus, these approaches concur on the point of establishing an ideal and unattainable model in reality. Secondly, Brachtendorf maintains that for Christ, suffering is to realise the aim of saving humans from passions and helping them regain the state of tranquility without perturbations. This does not deviate from the Stoic goal. ${ }^{162}$ Brachtendorf explains that Augustine's aim is not to attack the ideal of apatheia, but to criticise the dropping of the group of positive passions. ${ }^{163}$ Both the Stoics and Augustine are directed to the state of firmness and perfection, sharing the same ideal of freedom from passions. ${ }^{164}$ Brachtendorf's opinion is that Augustine's formulation of apatheia and eupatheia does not differ from the Stoic position in theory; it is only Augustine's religious therapy model for achieving these ends that is different.

According to Gerd Van Riel, Augustine incorporates philosophical ideas in his late thought rather than deviating from them, but he argues that Augustine adopts the Neoplatonic scheme of pleasure. Van Riel mentions that Augustine's account of eupatheia is to a certain extent "reinterpretation" instead "misinterpretation", as has been stated in the previous section. As for the passions in the afterlife, Van Riel emphatically points out that Augustine does not deviate

161 "Christ's state of mind is different from that of a human mind, because in us the rulership of reason is always endangered, whereas he due to his Deity has full command over his passions and even produces them deliberately...To criticize this ideal [apatheia] by reference to Jesus Christ makes no sense, because Christ's state of mind can not be reached by humans, neither on earth nor in heaven". See Brachtendorf 1997, 304.

162 “Augustine's reflection on Christ's passions is not an attack on Stoic moral psychology. Instead, Augustine uses Cicero's analysis of the passions to explain Christ's way of therapy...In fact, freedom from passions is a necessary condition of salvation as far as negative second-order passions are concerned; there is no way to heaven for somebody who despairs of the chance of rescue. But since Christ deliberately suffered from passions, the Christian's fear of death does not prevent him from reaching the goal of goals". Brachtendorf 1997, 305-306. When interpreting the Stoic theory of passions and apatheia, Brachtendorf borrows Cicero's view and underscores its Stoic nature.

163 Brachtendorf concludes that there is a distinction between first-order passions and second-order passions in the Stoics, Cicero and Augustine. First-order passions are perturbations and motions of the mind, whereas second-order passions are always about first-order value judgments of good or evil, that is, emotions. Brachtendorf argues that the main difference between the Stoics and Augustine is the second-order passions, since the Stoics regard them as bad, but Augustine believes that some of them are positive and good. "Augustine harshly criticizes the Stoics for not allowing for these positive versions of passions. He polemically calls apatheia dullness (stupor). His objection against Stoic ethics in the tractatus LX [In Iohannis Euangelium tractatus] is not aimed at the ideal of apatheia as such but at the missing of a positive evaluation of second-order passions". Brachtendorf 1997, 304.

164 "In order to avoid falling victim to Augustine's polemics, it is important to compare the descriptions of the state of perfection...In his polemics Augustine likes to make his doctrine appear very different from the Stoic theory by emphasizing this point [passions in this life] and by concealing that his ideal of freedom from passions is the same as the Stoic one". Brachtendorf 1997, 296 (n. 24). 
from the Platonic framework. ${ }^{165}$ Van Riel concludes that Augustine accepts the passions of love and joy in the redeemed life, summarising his position in the following way, "Augustine points out that our will is accomplished or perfected (perficitur) when it attains what is was tending to, and when it takes rest in this attainment. The result of this is that the desire of the one who was seeking (appetitus quaerentis) is modified into the love of the one who feels joy (amor fruentis)". ${ }^{166}$ Van Riel further asserts that there are two conditions for this type of pleasure in Augustine, one is the satiation of the body and the other is the everlasting rest of the will in the harbour of God. Van Riel observes that in his theology, Augustine unites both the redeemed body and the will to the everlasting good without any deficiency and so that it is in line with the Aristotelian definition of pleasure (gaudium). ${ }^{167}$ Thus, Van Riel argues that Augustine retains the passions of joy and love in his theology of salvation without leaving the overall Platonic framework.

Concerning the debate of whether Augustine deviates from his philosophical predecessors on the issue of freedom from passions, it seems that both opposite interpretations have some correct insights, but they do not explore the underlying reason for Augustine changing his previous account of philosophical concepts, such as will, love, justice, propatheia, apatheia, eupatheia, nor do they explain his preference for a provocative writing style that some contemporary critics construe as his misunderstanding. I think that in his late thought, Augustine examines the Stoic and the Platonic teachings from the perspective of theological anthropology, providing a pessimistic perspective, using the lenses of original sin to interpret the human condition; at the same time, he is optimistic about the redemptive state of the citizens in the City of God by the grace of Christ. He therefore adopts a theological vantage point to evaluate philosophical values and terminology.

165 “...pleasure is worthwhile in itself. As we have seen, the gaudium in the redeemed life is a pleasure without any possible distress. This is in line with his acceptance of the passions in the good life. But this does not mean that he is leaving the overall Platonic framework. For the question of how to say that this gaudium can be called a pleasure is addressed by taking over peculiar Neo-Platonic schemes". Van Riel 2004, 530.

166 Van Riel 2004, 530.

167 "Thus, we can conclude that when Augustine transposes pleasure to the state of the redeemed body, he is doing the same as the pagan Neo-Platonists: he follows Aristotle rather than Plato". Van Riel 2004, 530. 
As distinct from the Stoic and the Platonic doctrines, Augustine employs two pivotal theological concepts, original sin and grace, which allow his worldview to include various levels. At the mundane world level, Augustine espouses a pessimistic orientation that is associated with the doctrine of original sin and he criticizes philosophers who "overrate" their personal powers and virtues, living in a state of "pride" (superbia) and egocentricity. On the one hand, Augustine argues that in the fallen condition, there is a weakening and distortion of the human will, love, and rational power. That condition also reveals a perverted tendency (pondus). ${ }^{168}$ On the other hand, the model of Christ established a righteous and undeflected value system and it offers new criteria for evaluating human conduct. To Augustine, philosophers themselves cannot become aware of their moral defect (for example, their arrogance) and depraved nature without an awareness of the uncontaminated values in Christ. At the eschatological level, Augustine believes that two cities of men will be differentiated. One will be saved by the grace of Christ and enter the City of God with corrected values and recovered cognitive abilities, receiving gifts of grace and participating in God with eternal rejoicing. The other (without redemption) will remain in the sinful state together with the Devil and receive eternal punishment from God. ${ }^{169}$ Augustine's theological doctrine consists of five crucial points: 1.The overwhelming power of original sin leads to a condition of misery; 2. Humans cannot save themselves through their own powers because their values and thinking are corrupted; 3 . The Saviour is not infected by original sin and provides a correct value model; 4 . In order to rectify the depraved condition, the Saviour voluntarily enters human reality and participates in human life as a sign of divine love and as a gift of grace; 5. The Saviour has sufficient power to deliver fallen humans from both their suffering and perverted condition. In comparison to the Stoics, it is evident that Augustine displays a pessimistic view towards mundane life, and he believes that an external power is

\footnotetext{
${ }^{168}$ Miikka Ruokanen presents a systematic analysis of Augustine's concept of pondus voluntatis et amoris. He states, "The principle of pondus consists of the tendency of the will and love of the rational beings either to conform to or to diverge from the primitive order of nature. Because of the Fall, in Augustine's terminology the word pondus, i.e. the weight, signifies basically the tendency of the vitiated rational beings to turn from being oriented upwards to downwards, i.e. from the Creator to the created". Ruokanen 1993, 39.

${ }^{169}$ CD 15.1: ...quod in duo genera distribuimus, unum eorum, qui secundum hominem, alterum eorum, qui secundum Deum uiuunt; quas etiam mystice appellamus ciuitates duas, hoc est duas societates hominum, quarum est una quae praedestinata est in aeternum regnare cum Deo, altera aeternum supplicium subire cum diabolo. Cf. CD 14.1.
} 
required to change a depraved nature into a better state. Furthermore, Augustine has complete confidence in supranatural grace and concludes that divine love will generously bestow gifts not limited to restoring the human distorted condition. These supranatural gifts are certainly limited to the elected, with the majority remaining under the righteous wrath of God towards our fallen humanity. Thus, the theoretical foundation for his theological doctrine of passions is formed by the assumption of a perverted human living pattern and a faith in a divine equitable value system as well as an eschatological fulfillment.

\section{Original sin and the embarrassing condition of passions}

Augustine observes the world through the lenses of original sin, describing the world as a distorted and miserable reality, one that involves turbulences of the soul. He cites various cases as evidence (for example, the force of natural punishments, diseases, starvation, deceptions of men, temptations of demons, and the disturbances in dreams and when awake) ${ }^{170}$ to demonstrate that depravity and punishment are not fictitious, but a genuine condition. Augustine poses the following question:

Who can describe in any discourse, who can comprehend in any process of thought, the number and severity of the punishments which disturb the human race in general? These punishments do not merely befall the malice and iniquity of the wicked, but belong to the condition of misery common to us all. ${ }^{171}$

Augustine continues to emphasize that no matter which state we are in, asleep or awake, false visions and terrors will always assail our wretched soul. Indeed, temptations from demons confuse our senses and seduce us to partake of a variety of evils without tranquility. ${ }^{172}$ For these reasons, we cannot avoid emotions in the mundane world, and they often lead us to pain and unhappiness.

170 CD 22.22: Quantus est metus, quanta calamitas ab orbitatibus atque luctu, a damnis et damnationibus, a deceptionibus et mendaciis hominum, a suspicionibus falsis, ab omnibus uiolentis facinoribus et sceleribus alienis! Quando quidem ab eis et depraedatio et captiuitas...Ipse postremo somnus, qui proprie quietis nomen accepit, quis uerbis explicet, saepe somniorum uisis quam sit inquietus et quam magnis, licet falsarum rerum, terroribus, quas ita exhibet et quodam modo exprimit, ut a ueris eas discernere nequeamus, animam miseram sensus que perturbet? Qua falsitate uisorum etiam uigilantes in quibusdam morbis et uenenis miserabilius agitantur.

171 CD 22.22: ...quot et quantis poenis genus agitetur humanum, quae non ad malitiam nequitiamque iniquorum, sed ad condicionem pertinent miseriamque communem, quis ullo sermone digerit? quis ulla cogitatione conprehendit?

172 CD 22.22: ...quamuis multimoda uarietate fallaciae homines etiam sanos maligni daemones nonnumquam decipiant talibus uisis, ut, etiamsi eos per haec ad sua traducere non potuerint, sensus tamen eorum solo appetitu qualitercumque persuadendae falsitatis inludant. 
In referring to the overwhelming power of original sin, Augustine addresses passions from the standpoint of the deprived soul and offers the following contending characterisations of passions in a theological context: (1) Passions are signs of a miserable and sinful condition; they disturb our soul and make the mind continuously unquiet. (2) Passions reflect weakness, but without them, life is not righteous. ${ }^{173}$ (3) Passions are right feelings in the lives of righteous men. ${ }^{174}$ (4) We do not hope for a passionate condition in our future life. ${ }^{175}$ (5) Passions are good when love and will are directed towards good; otherwise, they are bad. (6) The state of impassibilitas as a condition of a peace of mind is desirable, but it may manifest itself as a numbness in this life. (7) Tranquil contemplation toward God without distractions should not be neglected. ${ }^{176}$ These characterisations reflect an embarrassing condition of passions in the terrestrial city that is portrayed by Augustine from the vantage point of his theological anthropology. The departure point for Augustine to evaluate the role and nature of passions is his conception of the perverted order of nature resulting from original sin. In his theological view of values, the notion of eliminating passions through rational powers reflects arrogance.

\section{The weight of will and the vice of impassibility in the earthly city}

Compared to the Stoics and the Platonists, Augustine places more emphasis on the role of the will in discussing passions because he believes that it is the decisive factor in the conflict between rational and non-rational impulses. ${ }^{177}$ Nevertheless, Augustine's attitude toward the human will is ambiguous, as is conveyed by his discussion of the principle of the weight (pondus) of the human will. In the theology

173 CD 14.9: Habemus ergo eas ex humanae condicionis infirmitate... Sed dum uitae huius infirmitatem gerimus, si eas omnino nullas habeamus, tunc potius non recte uiuimus.

174 CD 14.9: ... et quia rectus est amor eorum, istas omnes affectiones rectas habent... Hilarem datorem diligit Deus.

${ }^{175}$ CD 14.9: ...etiam cum rectas et secundum Deum habemus has affectiones, huius uitae sunt, non illius, quam futuram speramus, et saepe illis etiam inuiti cedimus.

176 CD 19.19: Nec sic actuosus ut contemplationem non requirat Dei.

${ }^{177}$ Irwin maintains that as distinct from the rationalism in Peripatetics and the Stoics, Augustine endorses the role of the will and inspires medieval voluntarists: "Aristotle does not recognize the self and its power of choice (arbitrium) as a further thing besides the rational and the non-rational parts. The Stoics give assent a more central role than Aristotle gives it, but in doing this they do not abandon rationalism...they reaffirm Socratic rationalism even more strongly. Augustine, however, appears to recognize the self that chooses as something apart from rational desire and passion, and therefore identifies the self especially with the will'. See Irwin 2007, 401. 
of the perverted order, a significant concept is the weight of the will and love (pondus voluntatis et amoris). The incorrectly directed pondus is a structural feature of the fallen state, which expresses the perverted values that derive from original sin. This concept does not exist in the Stoic and Platonic doctrines. From Augustine's perspective, the Stoic arguments for impassibility (impassibilitas) cannot be relied on because the rational ability to understand values is weakened and the will, having lost its original balance, is guided by the wrong tendency. Thus, the perfect state of impassibilitas might appear to be possible and virtuous in terms of Stoic values, but it becomes impossible and vicious in Augustine's understanding of the earthly world.

Notwithstanding, Augustine recognises the value of impassibilitas. He differentiates its sinful and sinless aspects based on his theological interpretation of the human conditions in different periods. In Eden before the Fall, the first humans were in a fully controlled state of mind and body without mental disturbances. This type of impassibilitas is therefore an obvious manifestation of their happiness before the disobedience brought on by their will. ${ }^{178}$ By contrast, in the earthly city after the Fall, humans have a will with an evil self-centred pondus. In this condition, apatheia displays vice and distorted behaviour; passions are unavoidable and while many of them are sinful, some are required in a righteous life. ${ }^{179}$ Lastly, after the depraved will is restored in the Heavenly City, the elected will be redeemed from all sins and filled with constant and unsurpassable enjoyment without defect and mental disturbance. ${ }^{180}$ In other words, impassibilitas itself is a desirable state, but whether it is good or vice depends in which domain it is located in and how it is understood. Augustine reminds us that temptations from demons occur throughout a depraved life, but it is the evil will that leads humans to the city of death and, if they are not saved, transforms the limited miserable condition of their present life into eternal suffering. To avoid this fate, another external power is needed to save the depraved human will. The only restorer is the one who is a unity of both God

\footnotetext{
${ }^{178}$ CD 14.10: Amor erat inperturbatus in Deum atque inter se coniugum fida et sincera societate uiuentium, et ex hoc amore grande gaudium, non desistente quod amabatur ad fruendum. Erat deuitatio tranquilla peccati, qua manente nullum omnino alicunde malum quod contristaret inruebat. CD 14.13: In occulto autem mali esse coeperunt, ut in apertam inoboedientiam laberentur. Non enim ad malum opus perueniretur, nisi praecessisset uoluntas mala.

179 See $C D$ 14.9;14.11.

${ }^{180}$ See $C D$ 22.30. Cf. $C D$ 14.11.
} 
and man. ${ }^{181}$ Thus, Augustine argues that the crux of the matter of losing the goodness of impassibilitas is the disobedience of the will and its perverted tendency in the earthly city. He anchors his hope for correcting the twisted human pattern on the just Saviour, Christ.

\section{Grace of Christ and the therapy of passions}

Augustine appears to be ambivalent about the role of the Saviour. On the one hand, He should not be contaminated by human passions because they are an indication of the original sin and reveal the weak and embarrassing human condition. On the other hand, He has to subject Himself to human weakness and express the right emotions for the purpose of helping humans to become free from their emotional turbulence. Moreover, His redemption is a voluntary (voluntaria) act showing divine mercy and charity. Augustine emphasises that Christ's therapy of passions should be based on His real humanity and real divinity and show a perfect unity of divine and human emotions. ${ }^{182}$ Christ's shares in our mortality in order to let us participate in His immortality, as Augustine argues in De Trin. 13.9.12:

For if the Son of God by nature became the Son of man out of compassion for the sons of men...how much more credible it is that the sons of man by nature become the sons of God by grace, and dwell in God in whom alone and from whom alone the blessed can be made sharers of His immortality; and that we might be convinced of this, the Son of God was made a sharer of our mortality ${ }^{183}$

In this way, the corrupted human soul will be restored to the condition of the good natural order for which it had been created. ${ }^{184}$ The redemption is called "the grace

181 CD 14.11: Arbitrium igitur uoluntatis tunc est uere liberum, cum uitiis peccatis que non seruit. Tale datum est a Deo; Quod amissum proprio uitio, nisi a quo dari potuit, reddi non potest. Unde Ueritas dicit: Si uos Filius liberauerit, tunc uere liberi eritis. Id ipsum est autem, ac si diceret: "Si uos Filius saluos fecerit, tunc uere salui eritis". Inde quippe liberator, unde saluator.

${ }^{182}$ For Augustine's view of redemption, see Kelly 1977, 390-395. I shall proceed to the issue of divine "emotions" and human passions in the Passion of Christ in Chapter 5.3.

${ }^{183}$ De Trin. 13.9.12: Si enim natura Dei filius propter filios hominum misericordia factus est hominis filius...quanto est credibilius natura filios hominis gratia Dei fieri Dei filios et habitare in Deo in quo solo et de quo solo esse possint beati participes immortalitatis eius effecti, propter quod persuadendum Dei filius particeps nostrae mortalitatis effectus est? Lenka Karfíková notes that "Grace (gratia) is given gratis, for it is not given according to previous merits. It is bestowed by God not because some are worthy of it, but because he himself wants it so". See Karfíková 2012, 246.

184 Augustine interprets the good natural order and the corresponding tranquility of mind in $C D$ 19.13: Pax itaque corporis est ordinata temperatura partium, pax animae inrationalis ordinata requies appetitionum...pax omnium rerum tranquillitas ordinis. Ordo est parium dispariumque rerum sua cuique loca tribuens dispositio. For Augustine's view of the cure of the soul, see Paul Kolbet, Augustine and the Cure of Souls: Revising a Classical Ideal (Notre Dame, Indiana: University of Notre Dame Press, 2010). 
of Jesus Christ" (gratia Salvatoris Christi). ${ }^{185}$ His grace is not confined to healing; redeemed humans will have more freedom from passions in the future, owing to their not being able to sin in Heaven. They will consequently be free from emotions of the sinful state and will be in constant delight. God will bestow upon them more abundant gifts of grace and make the citizens of the City of God participate in Him (quo [Deo] faciente dii essemus eius participatione) ${ }^{186}$ with an eternal happiness. Augustine describes the state of the will in the last chapter of De civitate Dei as follows:

In the divine gift of free will there was to be observed a gradation such that man should first receive a free will by which he was able not to sin, and finally a free will by which he was not able to sin: the former being given to man in a state of probation, and the latter to him in a state of reward. But because human nature sinned when it had the power to sin, it is redeemed by a more abundant gift of grace so that it may be led to that state of freedom in which it cannot sin...In the Heavenly City, then, there will be freedom of will: one freedom for all, and indivisible in each. That city will be redeemed from all evil and filled with every good thing; constant in its enjoyment of the happiness of eternal rejoicing; forgetting offences and forgetting punishments. ${ }^{187}$

In Augustine, the citizens of the Heavenly City are not only free from mundane passions, but they also enjoy the freedom of being unable to sin and they regain their eternal peace of mind. This impassibilitas with respect to negative things is compatible with constant enjoyment in rejoicing (iucunditate gaudiorum) in participating in God. By participating in God, the impassibilitas is associated with

185 CD 22.22: Ab huius tam miserae quasi quibusdam inferis uitae non liberat nisi gratia Saluatoris Christi, Dei ac Domini nostri (hoc enim nomen est ipse Iesus; interpretatur quippe Saluator), maxime ne post hanc miserior ac sempiterna suscipiat, non uita, sed mors. Cf. CD 14.11: Detrahitur porro malum non aliqua natura, quae accesserat, uel ulla eius parte sublata, sed ea, quae uitiata ac deprauata fuerat, sanata atque correcta. Arbitrium igitur uoluntatis tunc est uere liberum, cum uitiis peccatisque non seruit. Tale datum est a Deo, quod amissum proprio uitio nisi a quo dari potuit reddi non potest. Unde Ueritas dicit: Si uos Filius liberauerit, tunc uere liberi eritis. Id ipsum est autem ac si diceret: "Si uos Filius saluos fecerit, tunc uere salui eritis". Inde quippe liberator unde saluator.

186 CD 22.30: Dies enim septimus etiam nos ipsi erimus, quando eius fuerimus benedictione et sanctificatione pleni atque refecti. Ibi uacantes uidebimus quoniam ipse est Deus; quod nobis nos ipsi esse uoluimus, quando ab illo cecidimus, audientes a seductore: Eritis sicut dii et recedentes a uero Deo, quo faciente dii essemus eius participatione, non desertione. Cf. De Trin. 14.14.20.

187 CD 22.30: Seruandi autem gradus erant diuini muneris, ut primum daretur liberum arbitrium, quo non peccare homo posset, nouissimum, quo peccare non posset, atque illud ad comparandum meritum, hoc ad recipiendum praemium pertineret. Sed quia peccauit ista natura cum peccare potuit, largiore gratia liberatur, ut ad eam perducatur libertatem, in qua peccare non possit...Erit ergo illius ciuitatis et una in omnibus et inseparabilis in singulis uoluntas libera, ab omni malo liberata et impleta omni bono, fruens indeficienter aeternorum iucunditate gaudiorum, oblita culparum, oblita poenarum; nec ideo tamen suae liberationis oblita, ut liberatori suo non sit ingrata. 
divine love (caritas). In this respect, Augustine's definition of freedom from passions has developed beyond the Stoic and Platonic doctrines in combining impassibilitas with the supranatural love.

It is evident that in his Christian belief, Augustine is dissatisfied with the Stoic or the Platonic framework. However he reinterprets their values on the basis of his pessimistic view of the human condition as a consequence of original sin and his eschatological views. Augustine does not believe that the Stoic ideal state of impassibilitas could be attained by humans, as the decisive motivational source of passions (voluntas) is corrupted. Departing from the Stoics, he approves certain appropriate and moderated emotions, providing they are controlled by the right will and love. Augustine believes that Christ provides the correct criteria for emotions. In eschatology, Augustine insists on the supranatural improvement of the life of the elected who will be harmoniously united in Heaven through divine love. This spiritual life surpasses the Stoic and the Platonic impassibilitas as well as the emotional state of the first human beings in Eden. Thus, Augustine develops a compound theological doctrine of passions that incorporates both pessimistic and optimistic aspects. This is partly based on his considerations on the therapy of passions in philosophical traditions.

Gerard O'Daly, Marcia Colish and Peter King observe correctly that Augustine's deviates from philosophical views in constructing his theological theory. However, what they do not state is that Augustine's theology also contains traces of the Stoic and Platonic ideal of freedom from passions. This is detected by Johannes Brachtendorf and Gerd Van Riel, but they do not pay attention to Augustine's having changed the connotation of freedom from passions, for he abandons the philosophical framework, even though he adopts the same terminology. This means that Augustine attempts to reach a balance between deviation and inheritance with respect to philosophical traditions in his late theological construction concerning the theme of freedom from passions. From this perspective, Augustine's alleged "misunderstandings" are not misinterpretations, but are his considered deviations from his predecessors' teachings, achieved through examining their doctrines from different angles and transforming their terminology and doctrine. 
I have argued in the previous sections of this chapter that in dealing with the philosophical conceptions of propatheia, metriopatheia, apatheia and eupatheia, Augustine does not completely follow any of his philosophical predecessors, but offers instead a compound vision and synthetic evaluation from the perspective of theological anthropology. He presents both pessimistic and supranaturally optimistic views on human conditions in the different stages of history. In his theological doctrine of values, some pivotal philosophical concepts (for example, voluntas, amor, and ratio) are assigned theological connotations that reflect more the transformation process in Augustine rather than a misunderstanding. In referring to the two realms, the city of men and the City of God, Augustine deliberately uses the pessimistic lenses of original sin and the optimistic vision of divine grace in presenting his belief in the freedom from self-love (amor sui) of believers and in their eternal happiness in Heaven.

\subsection{The Main Lines of Augustine's Understanding of the Will and Passions}

Before I proceed to a more detailed discussion on the theological context of passions in Augustine, I would like to provide a general overview of how he addresses emotions on the basis of his framing of philosophical theories. Regarding the issue of the will and passions, Augustine can use the notion of will rather broadly, as the source of all behavioural movements in humans and animals alike. In a more narrow sense, the term refers to the basic motivational attitude in the highest part of the soul (will or love) that can reject the activities of the lower parts as well as the movements caused by these activities. Owing to the nature of the will as the centre of motivation, Augustine occasionally refers to all passions as volitions. From the viewpoint of the controlling power of the will, the non-prevented actual passions and their behavioural impulses can also be regarded as being voluntary, after the spontaneous initial stage. This hierarchy between the will and the passions is manifested in Augustine applying the Stoic classification of the different types of passions as forms of will or love, the passions being good or evil according to whether the controlling the will or love is regarded as either good 
or evil. ${ }^{188}$

While the will as a general motivational centre or love is dispositional, ${ }^{189}$ its controlling function is seen in its actual assent or dissent with respect to particular suggestions. Augustine addresses the difference between the controlling power and spontaneous emotional movements in his discussion of first movements where he applies the Stoic analysis. He diverges from the Stoics, however, by referring to the spontaneous first movements as passions and instead of prepassions, as the Stoics did (see section 3.1 above). While the Stoics regarded the first movements without an assent as being morally neutral, but nonetheless potentially disturbing mental acts and something that one should eradicate, Augustine concluded that they are often evil and should be rejected as soon as possible, as they are regarded as voluntary if not expelled. Augustine holds that their being immediately passions is evidence that the soul is not able to fully control itself, being spontaneously moved by the lower part. This, in Augustine's theological anthropology, reveals the damage of the fallen soul. The soul suffers from the relative autonomy of the passions with respect to the controlling power. Moreover, spontaneous passions are often evil, which indicates this damage even more clearly. Christians who are motivated to avoid sinful movements realise that they occur before an opportunity to prevent them. Owing to their pride and self-satisfaction, the Stoics do not refer to first movements as passions. The Christians are more humble and confess their lack of full control, resulting from the disturbing domination of the emotional powers as well as the impurity of the first movements as spontaneous temptations to sins.

According to Augustine, what occurred in the Fall was that the will of the intellectual part of the soul turned away from loving God to loving itself instead as the ruler and authority. This turn of love is pride (superbia), the source of all sins. ${ }^{190}$ Even though the first pride is a free choice by the will and the continuous attitude of the fallen souls without the medicine of grace, Augustine also regards pride as a passion. When Adam fell away from the love of God and the ordered social love, the self-chosen sinful order became the constitution of the soul. Its damaged mode of functioning is the burden of the original sin which manifests itself in egoism, disordered spontaneous passions, and emotional disturbances. This negative

\footnotetext{
188 See $C D$ 14.6-7. For the notion of will, see Knuuttila 2004, 152-172.

189 See also Byers 2013, 92-94.

${ }^{190}$ CD 12.1; 12.6; 14.13; De Trin. 12.14; 13.23.
} 
experiential reality demonstrates the consequences of pride, the misguided attempt to become the Lord of one's life. Furthermore, the emotional part of the soul functions autonomously and without order, being changed by original sin to the extent that it produces desires, fears, and sufferings. These passions, which did not belong to it before the Fall, are triggered by the sinful evaluation of sensory things and imaginations in accordance with the perverse self-love of persons turned into themselves (incurvatus in se). This is particularly clear in the case of psychosomatic sexual passions (concupiscentia) and the inclination to social dominance (libido dominandi). (See Chapter 4 below).

Due to the impact of Stoicism on Augustine's thought, he occasionally refers to emotional movements of the soul as disturbances, particularly in the context of sinful mental phenomena. However, Augustine also operates with the Platonic notion of the divisions of the soul and argues that its destroyed hierarchic structure explains the experienced disturbances. He also differs from the Stoic position that all emotions are evil. According to Augustine, even fallen, disturbed souls may show compassion as well as adequate fear and sorrow, which derive from human sociability and are not evil as such, even though the general human motivation is not as good as it was before the Fall and people are ultimately dominated by sinful self-love. ${ }^{191}$

Concerning the freedom from passions, Augustine distinguishes between three different uses of apatheia (impassibilitas) in CD 14.9: Firstly, apatheia refers to freedom from disturbing thoughts that give rise to sins if not expelled as soon as possible. This theological apatheia is not possible in the present life. It pertains to Adam and Eve before the Fall and is also a characteristic of Heavenly life. Secondly, if apatheia refers to the ability to restrain oneself and remain immune to any emotions in this life as the Stoics claim, it becomes a form of pride and insensitivity. Thirdly, if apatheia is used to describe a condition in which there is no fear, pain, or other negative experiences, it is the apatheia that Adam and Eve experienced in paradise and the blessed ones experience in Heaven. None of these three types of freedom from emotions describes the present condition of human beings, whether Christians or not. Theological apatheia with respect to freedom also James Wetzel, Augustine and the Limits of Virtue (Cambridge: Cambridge University Press, 1992), 45-111; 219-235. 
from sinful movements is something the Christians hope for, and their will and emotions are improved in this respect through the supernatural influence of grace. The impact of grace is the only efficacious therapy of emotions, and not even that can make humans completely free from evil movements until the substantial transformation of the damaged soul in Heaven. (See Chapter 5 below).

Augustine does not develop a nuanced theory on the psychology of passions, but he is nevertheless very interested in the emotional aspects of both internal and external human behaviour. While Augustine occasionally employs the notion of will when discussing passions, he also maintains that occurrent passions often suggest things that are against the preferences of one's will. The issue of how to free oneself from sinful passions will be addressed in the next chapter. 



\title{
CHAPTER FOUR: THE RENEWAL AND THE IMPROVEMENT OF PASSIONS IN SOCIAL LIFE
}

\begin{abstract}
Nec sic esse quisque debet otiosus, ut in eodem otio utilitatem non cogitet proximi, nec sic actuosus, ut contemplationem non requirat Dei...Itaque ab studio cognoscendae ueritatis nemo prohibetur, quod ad laudabile pertinet otium. (CD 19.19)

Quam ob rem otium sanctum quaerit caritas ueritatis; negotium iustum suscipit necessitas caritatis. Quam sarcinam si nullus inponit, percipiendae atque intuendae uacandum est ueritati; si autem inponitur, suscipienda est propter caritatis necessitatem; sed nec sic omni modo ueritatis delectatio deserenda est, ne subtrahatur illa suauitas et opprimat ista necessitas. (CD 19.19)
\end{abstract}

Transibo ergo et istam naturae meae, gradibus ascendens ad eum, qui fecit me. (Conf. 10.8.12)

In this chapter, I shall present a survey of Augustine's view of passions that occur in social life as well as his attitude towards the freedom from passions in the earthly city (terrena ciuitas). As mentioned earlier, many scholars contend that Augustine does not advocate freedom from passions in this life. Their main argument is that Augustine warns that to live righteously, impassibilitas should be avoided. Furthermore, he also characterises impassibilitas as an unhealthy and numb state, something worse than vices. However, it is also evident that throughout the different phases of his life, Augustine followed various sectarian ascetic ideals. ${ }^{1}$ In fact, his interest in asceticism preceded his conversion in Milan. Beginning in 395, he spent his continent life as a bishop in a monastery. There he established monastic communities for practitioners and wrote treatises to advocate continence. $^{2}$ Augustine offers a rather controversial picture of whether one can justify adopting an ascetic tradition without maintaining emotional commitments to an earthly life.

Scholars often discuss Augustine's argumentation on passions in three contexts formed by his classification of human society based on the household

\footnotetext{
${ }^{1}$ For various ascetic traditions that influenced Augustine, such as Manichaeanism, Neoplatonism and some Christian ascetics represented by St Antony, Jerome, Basil of Caesarea and Gregory of Nyssa, see George Lawless, "Augustine's Decentring of Asceticism", in Augustine and his Critics, ed. Robert Dodaro and George Lawless (London and New York: Routledge, 2000), 142-145.

${ }^{2}$ In Retractationes 2.21-25, Augustine summarises the theme of marriage and monastic life in a series of treatises (De opere monachorum, De bono coniugali, De sancta uirginitate, De Genesi ad litteram, Contra litteras Petiliani, among others) to respond to the debate between Jovinian (Iouiniani haeresis) and Jerome. See P. G. Walsh, Augustine: De bono coniugali; De sancta uirginitate (Oxford: Clarendon Press, 2001), xxix; 148-151.
} 
(domus), city (ciuitas) and world (orbis terrae). ${ }^{3} \mathrm{I}$ shall evaluate various observations by these authors and analyse Augustine's attitudes in these contexts. In the first section, I shall describe the main lines of Augustine's social theory and trace the historical background of his conception of the two cities as well as its relevance to his perspective on passions. In the second section, I shall explore Augustine's views on sexuality, marriage (connubium) and abstinence (continentia), ascertaining whether these are aligned in terms of the merits among them and then determine Augustine's vision of concupiscence and continence. In section three, I shall examine Augustine's attitude towards ecclesiastical elitism and secularism, inquiring whether life in a monastery or the church ranks higher than living a secular life. In section four, I shall discuss Augustine's view on the "just war" and explore whether he is a pacifist, focusing on the concept of war and peace in his thought. On the basis of these analyses, I shall argue that Augustine shifts the issue of lifestyles into the field of spiritual life as well as the moral improvement of emotions. He therefore emphasises the gradual ascent (gradibus ascendens) of renewed passions as a realistic scenario of the aspired perfectionism that occurs through grace in the Heavenly City. In this sense, human merits, such as martyrdom, monastic asceticism or secular conjugal chastity, are envisioned as being different gifts from God for improvement. Augustine's notion of the improvement of emotions is supported by his faith in divine grace and the doctrine of perfect spirituality and happiness in the Kingdom of Heaven.

\subsection{The Main Lines of Augustine's Social Theory}

The horizontal and vertical lines in Augustine's theory of saeculum are composed of the themes of two cities (ciuitates duae) and pilgrimage (peregrinatio). ${ }^{4}$ In

\footnotetext{
${ }^{3}$ CD 19.7: Post ciuitatem uel urbem sequitur orbis terrae, in quo tertium gradum ponunt societatis humanae, incipientes a domo atque inde ad urbem, deinde ad orbem progrediendo uenientes. $C D$ 19.3: Hanc uitam beatam etiam socialem perhibent esse, quae amicorum bona propter se ipsa diligat sicut sua eisque propter ipsos hoc uelit quod sibi; siue in domo sint, sicut coniux et liberi et quicumque domestici, siue in loco, ubi domus est eius, sicuti est urbs, ut sunt hi qui ciues uocantur, siue in orbe toto, ut sunt gentes quas ei societas humana coniungit, siue in ipso mundo, qui censetur nomine caeli et terrae.

"Xia Dongqi suggests that the notion of "two cities" and the three periods of sacra historia (paradise, saeculum, and heaven) are closely related in Augustine. He distinguishes horizontal and vertical perspectives in Augustine's theory of saeculum, emphasising the notion of peregrinatio in analysing the doctrine of saeculum. See Xia Dongqi 2007, 65-82; 111. For the distinction between
} 
relation to this picture, Augustine outlines a human society consisting of inhabitants who intermingle and possess two different loves, caritas and cupiditas. These two loves coexist in the earthly city, but due to their opposite tendencies with respect to the pursuit of dominion, they lead to contrasting results in the anticipated future. The two cities as well as the corresponding loves represent the basic train of thought in Augustine's social theory, especially in his late work De civitate Dei. I shall trace the background of these ideas as well as their content.

Augustine's position on the conception of the two cities undergoes a process of development. The notion of two classes of humans (duo genera) first appears in Augustine's early writing De uera religione (389-391). ${ }^{5}$ In Enarrationes in Psalmos (392-395), he compares the future church to Jerusalem and refers to the image of two opposite symbolic cities, Jerusalem and Babylon. ${ }^{6}$ By dividing humans into two classes and by referring to symbolic cities, Augustine's tendency to formulate antithetically opposing forms of life becomes apparent. Beginning in the year 400, he continues to frequently mention the antithesis between Jerusalem and Babylon in some of his writings, such as De catechizandis rudibus and sermons (for example, see Mainz 9). ${ }^{7}$ However, Augustine is inclined to explain the "intermingled" nature of these two cities,

sacra historia and saecula historia in Augustine's theology, see R. A. Markus, Saeculum: History and Society in the Theology of St. Augustine (Cambridge: Cambridge University Press, 1988 [1970]), 1-21; Sacred and Secular: Studies on Augustine and Latin Christianity (Aldershot: Variorum, 1994), 84-85.

5 Augustine developed the conception of "two classes" (duo genera) in De uera religione prior to using the terminology of "two cities". See uera rel. 27.50: ...cuius tamquam unius hominis uita est ab Adam usque ad finem huius saeculi, ita sub diuinae prouidentiae legibus administratur, ut in duo genera distributum appareat. Many scholars take De uera religione as the earliest source for the idea of two cities, even though he does not use the term "duae ciuitates". See Van Oort 1991, 108; O’Daly 1999, 63.

${ }^{6}$ Augustine equates the church with Jerusalem with an angelic life distinguished from secularity in a sermon on Psalm 9, which probably was written in 392; En. Ps. 9.12: Ipse habitat in Zion, quod interpretatur speculatio, et gestat imaginem ecclesiae quae nunc est; sicut Ierusalem gestat imaginem ecclesiae quae futura est, id est ciuitatis sanctorum iam angelica uita fruentium, quia Ierusalem interpretatur uisio pacis. Praecedit autem speculatio uisionem, sicut ista ecclesia praecedit eam quae promittitur, ciuitatem immortalem et aeternam. A short time later, he orients to Jerusalem (or Zion) as the life to come, whereas Babylon represents the imprisonment in the present life (or the city of "confusion"). These are regarded as being opposites. See En. Ps. 148.4; 145.20. For the theme of Jerusalem and Babylon in Augustine, see Van Oort 1991, 118.

${ }^{7}$ O'Daly underscores the significance of the recently discovered sermon Mainz 9 (dated to 403405/6) as witnessing development of the theme of two cities, arguing that the contrasting image of Jerusalem and Babylon is frequently used to symbolise the earthly city and the City of God. See O’Daly 1999, 63. 
arguing that they are intermingled in the bodies, but separated by will. ${ }^{8}$ At approximately the same time, Augustine develops the account of the two loves (in angels and humans) as well as his conception of earthly pilgrimage (peregrinatio) of the city of God in De Genesi ad litteram (ca.401-415). ${ }^{9}$ This was a significant preparation for Augustine to further advance his cardinal doctrine of two cities from the perspective of love in De civitate Dei. Later, the eschatological vision of the two cities is adumbrated in Enchiridion (421/422), which parallels the closing books of De civitate Dei. ${ }^{10}$ This late work presents Augustine's thoughts on the doctrine of two cities, presenting a series of antithetical categories such as ciuitas caelestis versus terrena, ciuitas superna versus mundi, ciuitas aeterna versus temporalis, ciuitas sancta versus iniqua, ciuitas Dei versus Diaboli, ciuitas piorum versus impiorum, ciuitas immortalis versus mortalis, domus Dei (templum Dei) versus hominum, and ciuitas dilecta versus priuata, among others. ${ }^{11}$ Furthermore, the difference between "Jerusalem and Babylon" is mentioned in many places in the City of God as well, especially in Books 16 to $18 .{ }^{12}$ At the same time, the theme of love is further exploited in the sense of the two loves that construct these two cities. ${ }^{13}$ It is evident that Augustine's doctrine of the two cities in De civitate Dei encompasses most of the themes of his previous writings that

\footnotetext{
8 Augustine uses the terminology of "two cities" (duae ciuitates) for the first time in De catechizandis rudibus and stresses that these two cities are mixed with respect to bodies but not with respect to wills. See cat. rud. 19.31: duae itaque ciuitates, una iniquorum, altera sanctorum, ab initio generis humani usque in finem saeculi perducuntur, nunc permixtae corporibus, sed uoluntatibus separatae, in die iudicii uero etiam corpore separandae. He continues the symbolic use of Jerusalem and Babylon to refer to the two cities in cat. rud. 21.37: sicut autem Ierusalem significat ciuitatem societatem que sanctorum, sic Babylonia significat ciuitatem societatem que iniquorum, quoniam dicitur interpretari confusio.

${ }^{9}$ Gn. litt. 11.15.20: Hi duo amores, quorum alter sanctus est, alter inmundus; alter socialis, alter priuatus; alter communi utilitati consulens propter supernam societatem, alter etiam rem communem in potestatem propriam redigens propter adrogantem dominationem...quarum etiam quadam temporali conmixtione peragitur saeculum, donec ultimo iudicio separentur, et altera coniuncta angelis bonis in rege suo uitam consequatur aeternam, altera coniuncta angelis malis in ignem cum rege suo mittatur aeternum. Cf. Gn. litt. 12.28.56. These opposites are repeated in CD (especially Books 11-22). See O’Daly 1999, 64-65.

${ }^{10}$ En. Ps. 64.2 and ench. 111, see O'Daly 1999, 65-66.

${ }^{11}$ On the expressions for the two cities as well as their distributions in De civitate Dei, see Xia Dongqi 2007, 88-89. Cf. Van Oort 1991, 115-116.

${ }^{12}$ E.g., $C D$ 15.20; 16.10; 17.3-4; 17.12; 17.16; 18.2; 18.18; 18.22; 20.21; 22.6. See Xia Dongqi 2007, 89 (n. 6). Cf. Van Oort 1991, 119.

${ }^{13}$ En. Ps. 64.2: Duas istas ciuitates faciunt duo amores: Ierusalem facit amor Dei; Babyloniam facit amor saeculi. Interroget ergo se quisque quid amet, et inueniet unde sit ciuis. Cf. CD 14.28.
} 
have been mentioned above. ${ }^{14}$ However, this does not imply that the theme of the two cities in De civitate Dei is merely a repetition of Augustine's previous position. Parrish argues that even though there are similarities with his earlier works, Augustine deepens his conceptions of the mixture of the cities and two loves (duo amores) and presents a thematic complexity in De civitate Dei. ${ }^{15} \mathrm{In}$ other words, Augustine's understanding of the theory of two cities undergoes a long formulation process that constitutes a synthesis rather than a simple iteration.

While the relationship between the two cities can be characterised as an antithesis, this division does not represent an absolute dualism in this world. This is because Augustine's discussion is based on the theological tradition that postulates a complex whole of the citizens of terrena ciuitas and the ciuitas peregrina Dei. ${ }^{16}$ The citizen of the latter is a peregrinus in the historical world as well as an alien, not having a home here, but only in the eternal and better city in the prospective future. Thus, the concept of peregrinatio embeds the theme of the City of God in a dynamic historical perspective involving an origin (exortus), process (procursus) and merited ends (fines debiti). This pilgrimage is associated with the reality of the two cities in hoc saeculo, but it can also be traced to the life in Paradise before the Fall and extended forward to the heavenly life after the resurrection, thus forming a tripartite continuum. ${ }^{17}$ Augustine mentions this sequence several times in his De civitate Dei, not only as a significant historical line of the City of God, but also as the basis for the structure of the latter part of

\footnotetext{
${ }^{14}$ For the connections between these earlier works and the City of God on the exegesis of two cities, see O'Daly 1999, 265-267.

${ }^{15}$ John M. Parrish maintains that there is a "moral opacity" in Augustine's vision of the two cities associated with an imitative relationship and even "mutual reflection" between pride and charity (or the earthly city and the Heavenly City). Although the two cities (or two loves) are different in nature, it is difficult to differentiate them in this world, the earthly city being a sort of shadowy imitation of the Heavenly City, and pride as a self-centred love erroneously imitating charity. Parrish argues that Augustine's account of the two cities as an opaque and complex relationship is a deepening of his previous understanding. See Parrish 2005, 209-235. O'Donovan also notes that there is an important change in the conception of the two loves in Augustine's writings prior to his De civitate Dei. See Oliver O'Donovan, The Problem of Self-Love in St. Augustine (Eugene: Wipf and Stock Publishers, 2006), Chapter 3.

${ }^{16}$ At the level of saeculum, it is neither right to exaggerate the bipolarity of the two cities as an absolute dualism nor to emphasise that there is a third ciuitas, an independent and neutral area. For a discussion of the sources pertaining to Augustine's doctrine of the two cities, see Van Oort 1991, 235-254; Xia Dongqi 2007, 107-110; O’Daly 1999, 53-66.

${ }^{17}$ CD 1.35: Perplexae quippe sunt istae duae ciuitates in hoc saeculo inuicem que permixtae, donec ultimo iudicio dirimantur; De quarum exortu et procursu et debitis finibus quod dicendum arbitror, quantum diuinitus adiuuabor, expediam propter gloriam ciuitatis Dei, quae alienis a contrario comparatis clarius eminebit.
} 
the work (four books per part from Book 11 to 22). ${ }^{18}$ According to this writing scheme, Augustine does not separate the pilgrimaging city of God (ciuitas peregrina Dei) from history, but rather emphasises the different origin and ending of the two cities to better understand the mundane political and social life.

Let us now examine this tripartite division of history. The original providential design has all rational beings forming a sancta ciuitas, enjoying their supreme good, the Creator. ${ }^{19}$ They lived a beatific life (beata uita) in a harmonious society and they obeyed the natural law (lex naturae). ${ }^{20}$ To Augustine, this ciuitas was part of divine providence (diuina prouidentia) ${ }^{21}$ and it obeyed the natural order (ordo naturae) because the order and hierarchy of the cosmos was essential in the creation, displaying goodness and beauty. ${ }^{22}$ Augustine regards the natural order as the structuring principle of the prelapsarian ciuitas: "the peace of the Heavenly City is a perfectly ordered and perfectly harmonious fellowship in the enjoyment of God, and of one another in God. The peace of all things lies in the tranquility of order; and order is the disposition of equal and unequal things in

\footnotetext{
${ }^{18}$ Augustine repeats the tripartite division several times in $C D$ (for example, 1.35; 10.32; 11.1; 17.24) to indicate the direction of his work. In his letter to Firmus, Augustine stresses the significance of this type of division for formulating the symmetrical structure of the Books 11-22. Epistulae nuper in lucem prolatae 1A. 1:... sic enim a nobis pars eadem distributa est, ut quattuor ostenderent exortum illius ciuitatis totidem que procursum, siue dicere malumus, excursum, quattuor uero ultimi debitos fines. See O'Daly 1999, 71-73.

${ }^{19}$ Angels are the first citizens in the holy city (sancta ciuitas). Augustine argues that angels shared the immutable light when the light was created and became citizens in the holy city. $C D$ 11.7: ...aut lucis nomine significata est sancta ciuitas in sanctis angelis et spiritibus beatis. CD 11.9: Nunc, quoniam de sanctae ciuitatis exortu dicere institui et prius quod ad sanctos angelos adtinet dicendum putaui, quae huius ciuitatis et magna pars est et eo beatior, quod numquam peregrinata, quae hinc diuina testimonia suppetant, quantum satis uidebitur, Deo largiente explicare curabo...Cum enim dixit Deus: fiat lux, et facta est lux, si recte in hac luce creatio intellegitur angelorum, profecto facti sunt participes lucis aeternae, quod est ipsa incommutabilis sapientia Dei... ut ea luce inluminati, qua creati, fierent lux et uocarentur dies participatione incommutabilis lucis et diei. Cf. Conf. 12.15; Gn. litt. 1.32; 4.45.

${ }^{20}$ For lex naturae, see De sermone Domini in monte 11.32 .

${ }^{21}$ CD 14.11: Sed quia Deus cuncta praesciuit et ideo quoque hominem peccaturum ignorare non potuit: secundum id, quod praesciuit atque disposuit, ciuitatem sanctam debemus adserere, non secundum illud, quod in nostram cognitionem peruenire non potuit, quia in Dei dispositione non fuit. CD 11.10: Quoniam Deus non aliquid nesciens fecit, quod nec de quolibet homine artifice recte dici potest; Porro si sciens fecit omnia, ea utique fecit quae nouerat.

${ }^{22}$ En. Ps. 144.13: Ista contextio creaturae, ista ordinatissima pulchritudo, ab imis ad summa conscendens, a summis ad ima descendens, nusquam interrupta, sed dissimilibus temperata, tota laudat Deum. For the doctrine of ordo and ciuitas, Miikka Ruokanen provides a nuanced discussion in his book Theology of Social Life in Augustine's De civitate Dei, especially in Chapters 2-4, see Ruokanen 1993, 29-42; 77-111.
} 
such a way as to give to each its proper place". ${ }^{23}$ In this ordo, created things are classified in a hierarchy, with living things ranking above inanimate objects, the sentient above the insentient, rational beings above irrational ones, and immortals above mortals. As God's works, all these creations and the natural order are good. ${ }^{24}$ Nonetheless, Augustine elaborates that while rational beings have dominion over irrational beings, they are not created to rule over their equals: "He did not intend that His rational creature, made in His own image, should have lordship over any but irrational creatures". ${ }^{25}$ It is evident that in the initial ciuitas, these rational citizens formed a unified society, obedient to God's authority (auctoritas) and living in the light of the natural law and order. This created a centralised model for society-God's love as dominion over rational beings. However, the two cities originated from the depravity of some angels who refused to obey the mastery of God; they fell in love with their own power as if true authority belonged to themselves. ${ }^{26}$ As a consequence, they ceased praising the glory of God and turned their will against the higher dominus, indulging in the pursuit of their own glory with an appetite or desire (appetitus or concupiscentia). These angels thus violated the natural order and lapsed into an illusory state of self-expansion. As a result, rather than directing their love and concupiscence to the supreme good, they wrongly directed them to the created being (res creatum). This perverse direction of the angels' will and love is the fundamental cause of their sin (peccatum), as is as their pride (superbia) in their quest for ownership of

\footnotetext{
${ }^{23}$ CD 19.13: ...pax caelestis ciuitatis ordinatissima et concordissima societas fruendi Deo et inuicem in Deo, pax omnium rerum tranquillitas ordinis. Ordo est parium dispariumque rerum sua cuique loca tribuens dispositio.

${ }^{24} C D$ 11.16: In his enim, quae quoquo modo sunt et non sunt quod Deus est a quo facta sunt, praeponuntur uiuentia non uiuentibus, sicut ea, quae habent uim gignendi uel etiam appetendi, his, quae isto motu carent; et in his, quae uiuunt, praeponuntur sentientia non sentientibus, sicut arboribus animalia; et in his, quae sentiunt, praeponuntur intellegentia non intellegentibus, sicut homines pecoribus; et in his, quae intellegunt, praeponuntur inmortalia mortalibus, sicut angeli hominibus. CD 11.15: Non enim est ulla natura etiam in extremis infimis que bestiolis, quam non ille constituit, a quo est omnis modus, omnis species, omnis ordo, sine quibus nihil rerum inueniri uel cogitari potest; quanto magis angelica creatura, quae omnia cetera, quae Deus condidit! Cf. $C D$ 11.22; 11.23 .

${ }^{25}$ CD 19.15: Rationalem factum ad imaginem suam noluit nisi inrationabilibus dominari.

${ }^{26} C D$ 11.13: ...suo recusans esse subditus creatori et sua per superbiam uelut priuata potestate laetatus, ac per hoc falsus et fallax, quia nec quisquam potestatem omnipotentis euadit, et qui per piam subiectionem noluit tenere quod uere est, adfectat per superbam elationem simulare quod non est. CD 14.11: Postea uero quam superbus ille angelus ac per hoc inuidus per eandem superbiam a Deo ad semet ipsum conuersus et quodam quasi tyrannico fastu gaudere subditis quam esse subditus eligens de spiritali paradiso cecidit.
} 
power:

For the defections of the will are not towards evil things, but are themselves evil: that is, they are not defections towards things which are evil by nature and in themselves; rather, it is the defection of the will itself which is evil, because against the order of nature. It is a turning away from that which has supreme being and towards that which has less...Nor is pride the fault of him who gives power, or of power itself, but of the soul which perversely loves its own power, and despises a more righteous higher Power. Hence, he who perversely loves the good of any nature whatsoever is made evil through this very good even as he attains it, and is made wretched because deprived of a greater good. ${ }^{27}$

Augustine states that the depravity of these angels is due to their free choice, that of their will. This was a fall from an immutable good to a mutable good, from plenitude to deficiency, and from security to infirmity, ${ }^{28}$ but it all occurred due to the misguided direction of their will and love. Thus, the angels are divided into those who are good and the bad, constituting two cities distinguished by two loves (devoted to different objects), amor Dei (usque ad contemptum sui) and amor sui (usque ad contemptum Dei): "Even though angels rank above men in the natural order, good men are nonetheless placed above the wicked angels according to the law of righteousness". ${ }^{29}$ Afterwards, out of envy (inuidus), the fallen angel seduced Eve to yield her desire to sin and for Eve to seduce Adam. They were both disobedient to the commandment and authority of God. In other words, the formation of the two cities among the angels occurred prior to the Fall of the first humans and they were deceived by those envious angels who sought to share their depravity (such as inoboedientia, superbia, amor sui) with men.

Although the fallen angels and men could violate the natural order, they

\footnotetext{
${ }^{27} C D$ 12.8: Deficitur enim non ad mala, sed male, id est non ad malas naturas, sed ideo male, quia contra ordinem naturarum ab eo quod summe est ad id quod minus est...Nec superbia uitium est dantis potestatem uel ipsius etiam potestatis, sed animae peruerse amantis potestatem suam potentioris iustiore contempta. Ac per hoc qui peruerse amat cuiuslibet naturae bonum, etiamsi adipiscatur, ipse fit in bono malus et miser meliore priuatus.

${ }^{28}$ Timo Nisula presents a concise survey on the development of the notion of the "Fall" and the "punishment" in Augustine's works during various periods, such as De Genesi adversus Manichaeos, De uera religione, De libero arbitro, arguing that rational beings have genuine free choice of will and the corresponding voluntary actions before the Fall, but they fell into sin due to their own fault rather than necessity and received the just divine punishment (iusta diuina supplicia). This is obviously different from the Manichaean dualism. "Opposing the Manichaean, radically dualistic and materialistic view of evil, Augustine stresses that sin is not an involuntary event that could only be said to occur or happen in us without our own doing... On the contrary, sin is a result of the free choice of the will, and therefore it is appropriate that it should be punished". Nisula 2012, 68.

${ }^{29} \mathrm{CD}$ 11.16:...cum ordine naturae angeli hominibus, tamen lege iustitiae boni homines malis angelis praeferantur.
} 
were not able to escape the juridical function of the eternal law of righteousness (lex iustitiae). In an eschatological sense, a judgement that is just and deserved will be passed by the Lord (dominus) to distinguish the City of God from the city of the devil. ${ }^{30}$ Augustine believes that the citizens of the City of God will enjoy the state of ordered obedience to God, whereas the evil angels and all who belong to them will receive the subsequent just punishment as a result of their refusing the authority of God and choosing to love themselves rather than God. ${ }^{31}$ In the end, there is a sharp division between the two groups of citizens through the punishment of everlasting unhappiness and the eternal reward in the happy world; this implies some type of dualism. ${ }^{32}$ Augustine uses various opposite expressions to indicate the reasons for this differentiation, such as oboedientia-inoboedientia, pietas-impietas, superbia-humilis, fruitur-non fruitur Deo, and in Domino gloriatur-gloria in se ipsa. ${ }^{33}$ But the primary cause leading to a just punishment (iustum supplicium) is "the proud desire for their own power" (superba concupiscentia propriae potestatis). ${ }^{34}$ This means that Augustine ultimately attributes the origin and end of the fallen city to self-love (amor sui) ${ }^{35}$ that is

\footnotetext{
${ }^{30}$ CD 21.1: Cum per Iesum Christum dominum nostrum, iudicem uiuorum atque mortuorum, ad debitos fines ambae peruenerint ciuitates, quarum est una Dei, altera diaboli, cuius modi supplicium sit futurum diaboli et omnium ad eum pertinentium.

${ }^{31}$ CD 22.1: Ita natura, quae fruebatur Deo, optimam se institutam docet etiam ipso uitio, quo ideo misera est quia non fruitur Deo; qui casum angelorum uoluntarium iustissima poena sempiternae infelicitatis obstrinxit atque in eo summo bono permanentibus ceteris, ut de sua sine fine permansione certi essent, tamquam ipsius praemium permansionis dedit; qui fecit hominem etiam ipsum rectum cum eodem libero arbitrio, terrenum quidem animal, sed caelo dignum, si suo cohaereret auctori, miseria similiter, si eum desereret, secutura, qualis naturae huius modi conueniret.

${ }^{32}$ Augustine believes that according to lex iustitiae, there will be an adjustment based on the original natural order, that is, the mundane pilgrimaging citizens of the City of God will assume the places left in the Heavenly City by the fallen angels, forming an antithesis to the group of bad angels and their followers in Hell. CD 22.1: Qui de mortali progenie merito iusteque damnata tantum populum gratia sua colligit, ut inde suppleat et instauret partem, quae lapsa est angelorum.

${ }^{33}$ See $C D$ 14.28.

${ }^{34}$ Gn. litt. 11.11.15: Magna opera domini, exquisita in omnes uoluntates eius...Cur ergo non permitteret temtari hominem illa temtatione prodendum, conuincendum, puniendum, cum superba concupiscentia propriae potestatis quod conceperat pareret suoque fetu confunderetur iustoque subplicio a superbiae atque inoboedientiae malo posteros deterreret, quibus ea conscribenda et adnuntianda parabantur? Cf. Gn. litt. 11.13.17; 11.30.39; De Trin. 12.16. Timo Nisula maintains that concupiscentia potestatis, as a peruersus sui amor, plays a fundamental role in the chain of events of the Fall, which comprises the contra-position of the two loves as well as the consequent two cities. Nisula 2012, 99-100; Cf. Ruokanen 1993, 79-80.

${ }^{35}$ Augustine contrasts two types of love in Gn. litt. 11.15.20 (Hi duo amores, quorum alter sanctus est, alter inmundus; alter socialis, alter priuatus...), as an opposition between amor sui and amor Dei, or between cupiditas and caritas. In this context, Augustine is stressing the connotation of
} 
portrayed as a striving of its citizens for their own dominion without piety. Selflove therefore becomes a central notion in Augustine's social theory.

Augustine does not fully juxtapose the two citizens at the intermediate mundane stage. In addition, when he considers the complexity of the concept of self-love, Augustine uses an opaque image of the earthly city. Firstly, self-love is a mark of original sin and it is common to all men. As a desire for power of one's own, self-love reflects a degraded tendency of the will to orient towards inferior good rather than supreme good. The citizens of the Heavenly City and the earthly city, in the sinful state, cannot rid themselves of this tendency. As for the pilgrimage citizens (ciuitas caelestis peregrina in terra), their realistic mission is not to completely eliminate the desire for self-love, but to search for the right love to avoid being bound by evil desire. This grace-based pursuit of right love, available to humans but not fallen angels, is an expedient device to counter the negative effects brought on by depravation instead of eradicating the egoistic desires once for all, which indicates the complex situation of fallen humans. ${ }^{36}$ Augustine is not interested in providing a positive orientation for the concept of self-love, but reveals its embarrassing nature and inevitability in the saeculum, since no one can completely break away from it in this life. Thus, the mixed state of the citizens of the two cities in one society is an inherited punishment as evidenced by a deprived inclination to self-love.

Secondly, the desire for dominion that is subjected to self-love is transformed into the political and social life as libido dominandi. A significant manifestation of evil self-love is the tendency to imitate the authority of God and citizens of both cities are guilty of this. If one's desire for self-love is not

priuatus amor and the downward movement of cupiditas as amor peruersus as hallmarks of selflove. Moreover, he refers it to the slipping from the universal community to the private as "the beginning of sin" and "the root of all evil". See De Trin. 12.9.14: potestatem quippe suam diligens anima a communi uniuerso ad priuatam partem prolabitur, et apostatica illa superbia quod initium peccati dicitur, cum in uniuersitate creaturae deum rectorem secuta legibus eius optime gubernari potuisset, plus aliquid uniuerso appetens atque id sua lege gubernare molita, quia nihil est amplius uniuersitate, in curam partilem truditur et sic aliquid amplius concupiscendo minuitur, unde et auaritia dicitur radix omnium malorum. On the idea of self-love as a fall and the related division of two cities, see Markus 1994, 245-254.

${ }^{36}$ O'Donovan lists three quotations from Augustine to demonstrate that Augustine's attitude toward the concept of "self-love" looks dilemmatic: 1. "The primal destruction of man was selflove". 2. "There is no one who does not love himself; but one must search for the right love and avoid the warped". 3. "Indeed you did not love yourself when you did not love the God who made you”. See O’Donovan 2006, 1. 
redirected toward the right object (God and neighbours), one is isolated from the community and turned to a self-centered pursuit of the perverse dominion. If those who imitate authority are seeking the love of their community as well as God, this will manifest itself as caritas rather than as cupiditas. We see that the imitation of authority constitutes yet another shared feature of two citizens in human society. Augustine presents these two features, the mixed body (corpus permixtum) and the desire for domination, at three levels: household, city, and world.

\section{(1) Household (domus)}

For an ancient Roman family, the household was subjected to the authority of paterfamilias, which established a patriarchal foundation for the community and society. This paterfamilias has dominion (dominium or potestas) over family members (wife, children, relatives or adopted children), as well as servants, slaves and property. Even though there are some differences between the concepts of familia and domus, ${ }^{37}$ the most important household relationships that are anchored in the power of paterfamilias are the husband-wife, father-children, master-slaves, and owner-properties, and these form the microcosmic part of the social web. The paterfamilias has the patria potestas to punish family members who disturb domestic peace (pax domestica). This domestic discipline reflects the transcendental authority of God in Augustine. This imitation of dominion is mainly evident in the following relationships:

(a) Husband over wife. The primal family unit that represents a servile dependence is the conjugal relation. If a wife is subdued to her husband's dominion, this is a pax recta; if the reverse occurs, this is a pax peruersa. ${ }^{38}$ As an

\footnotetext{
${ }^{37}$ The concept of familia refers to all agnati, the kin-core, dependants, and other related persons (personae) including slaves and servants, whereas the terminology of domus covers a wider semantic range that includes property, physical house, estate, kinship group, slaves, etc. Within a family, there are also different stereotypes of wife are possible, which depend on the contract. If the marriage is sine manu, the wife is still reserved in her father's familia, not in her husband's potestas; whereas in the case of manus marriage, she enters into the familia of her husband and his potestas. After the second century AD, the sine manu marriage became common and women's family status was somewhat enhanced. See Richard P. Saller, Patriarchy, Property and Death in the Roman Family (Cambridge: Cambridge University Press, 1994), 74-88. For an examination of the usage of paterfamilias and the form of the Roman family see also Saller, "Pater Familias, Mater Familias, and the Gendered Semantics of the Roman Household", in Classical Philology 94 (1999), 182-193.

${ }^{38}$ Brent D. Shaw, "The Family in Late Antiquity: The Experience of Augustine", Past \& Present 115 (1987), 28.
} 
example, consider Augustine's account of his own family, where Monica was obedient to her husband, serving him as her lord (tradita uiro seruiuit ueluti domino). She even tolerated his infidelities without starting a quarrel. Monica also advised her peers who suffered from domestic violence to serve their angry husbands as a master; otherwise, they would receive more maltreatment. ${ }^{39}$ In Augustine's time, the paterfamilias could maintain other sexual relationships as well (such as adulterous liaisons, concubines, and prostitutes). In a certain sense, sex was a property-dominated act for the master of the household. ${ }^{40}$

(b) Father over children. A delicate bilateral relationship existed between a father and his son(s). While the father expected sons to inherit his property and estate, his children were completely subjected to their father's authority and they often suffered from his beatings. The death of a father meant that the power of materfamilias was often increased. ${ }^{41}$ The schoolmasters (magistri) served as disciplinarian substitutes for parents, and these schoolmasters also imposed their auctoritas upon young children through using different corporal punishments, such as the rod, the strap, and the cane. ${ }^{42}$ Augustine harboured painful memories of the beatings that he received as a boy and he regarded them as "a great and

\footnotetext{
${ }^{39}$ Conf. 9.9.19: Ubi plenis annis nubilis facta est, tradita uiro seruiuit ueluti domino et sategit eum lucrari tibi loquens te illi moribus suis, quibus eam pulchram faciebas et reuerenter amabilem atque mirabilem uiro...Denique cum matronae multae, quarum uiri mansuetiores erant, plagarum uestigia etiam dehonestata facie gererent, inter amica conloquia illae arguebant maritorum uitam, haec earum linguam, ueluti per iocum grauiter admonens, ex quo illas tabulas, quae matrimoniales uocantur, recitari audissent, tamquam instrumenta, quibus ancillae factae essent, deputare debuisse; proinde memores conditionis superbire aduersus dominos non oportere.

${ }^{40}$ For instance, Augustine himself maintained a sexual relationship with a concubine for many years (from 372 to 385 ) and subsequently abandoned her. Before marrying his 10-year-old childbride, Augustine took another concubine as his sexual object. (Conf. 6.13.23; 6.15.25) It was certainly common for men to have concubines in their own household (in domo suis), but Augustine was against this habit. Augustine warned in Serm. 224.3: "Are you saying that I am not permitted to do what I want in my own house? I say to you, 'It is not permitted. Men who do this go to hell, and will burn in eternal fire"'. (Cf. Conf. 2.3.7.) See Shaw 1987, 16, 30 and 45.

${ }^{41}$ After the death of Augustine's father, Patricius, Monica managed and controlled the property of the family and it was only after her death in the spring of 387 that Augustine succeeded her completely in the management of the paternal house and property. In Ep. 130.2.5-3.8, Augustine also mentions a case in which a materfamilias (a noble widow) had full dominion over the property of her family, even though she had sons and grandsons. See Shaw 1987, 33.

${ }^{42} C D$ 22.22: Quid enim sibi uolunt multimodae formidines, quae cohibendis paruulorum uanitatibus adhibentur? Quid paedagogi, quid magistri, quid ferulae, quid lora, quid uirgae... Cf. Conf. 1.9.14. See also Chadwick 2009, 6; Brown 2000, 23-28.
} 
painful evil" (magnum tunc et graue malum). ${ }^{43}$ Augustine compared the servile dependence inherent in the patriarchal dominion over children to that between a domesticator and his cattle (iumenta). ${ }^{44}$

(c) Master over slaves. The ownership of paterfamilias included slaves who served as a type of property. The central feature of slavery was the complete control of slaves (body, labour, relatives, etc.) under a master's extreme authority. Augustine mentions that a common relationship in a domus is the one between the master and his slaves; nearly every household has this ownership. ${ }^{45}$ This masterslave structure was a legal part of the ancient Roman family representing the honour and authority of the paterfamilias.

(d) Owner over properties. The basic semantic meaning of paterfamilias is that he is the proprietor of an estate, which indicates the owner's economic power and his corresponding social status. This property was an embodiment of the master's dominium, and his social rank was reflected in how many slaves and servers he could dominate in his domus. The fundamental part of a man's property consisted of other subjected persons along with the means of production, manifesting the potestas patri. ${ }^{46}$

These four overlapping relationships represent the authority of the paterfamilias, which resembles the hierarchical natural order and God's transcendental authority. This family structure involves either good or bad paterfamilias, which means expressing caritas or cupiditas by treating their property and their family members kindly or badly. However, these two loves within a household are often interwoven at the practical level, with good or bad

\footnotetext{
${ }^{43}$ Conf. 1.9.14: Deus, Deus meus, quas ibi miserias expertus sum et ludificationes, quandoquidem recte mihi uiuere puero id proponebatur, obtemperare monentibus...et cum me non exaudiebas, quod non erat ad insipientiam mihi, ridebantur a maioribus hominibus usque ab ipsis parentibus, qui mihi accidere mali nihil uolebant, plagae meae, magnum tunc et graue malum meum.

${ }^{44}$ En. Ps. 31.2.23; Serm. 55.4.4; Serm. 13.8.9; Ep. 133.2. See Shaw 1987, 23.

${ }^{45}$ En. Ps. 124.7: Prima et quotidiana potestas hominis in hominem domini est in seruum. Prope omnes domus habent huiusmodi potestatem. For Augustine's position on slavery, see Peter Garnsey, Ideas of Slavery from Aristotle to Augustine (Cambridge: Cambridge University Press, 1996), 206-219; John M. Rist, Augustine: Ancient Thought Baptized (Cambridge: Cambridge University Press, 1994), 236-242; Gervase Corcoran, Saint Augustine on Slavery (Roma: Institutum Patristicum "Augustinianum", 1985); Aaron D. Conley, "Augustine and Slavery: Freedom for the Free", in Augustine and Social Justice, ed. Teresa Delgado, John Doody and Kim Paffenroth (Lanham: Lexington Books, 2015), 131-144.

${ }^{46}$ For the ownership of paterfamilias, see Kevin Hughes, "Local Politics: The Political Place of the Household in Augustine's City of God", in Augustine and Politics, ed. John Doody, Kevin Hughes and Kim Paffenroth (Lanham: Lexington Books, 2005), 145-164.
} 
paterfamilias occurring in most social groups. Augustine emphasises that both the owners and the owned should maintain domestic peace, obeying the natural and social order. Charity (caritas) and obedience are bilateral obligations that need to be embodied in daily family life. This is because good paterfamilias and the servants, who strive to orient their self-love toward the higher good, are both pilgrimaging in the temporal mundane world toward the holy heavenly city, even though they are intermingled with those who abuse their cupiditas in the domus.

\section{(2) City (ciuitas)}

The concept of the city is an extension of the concept of the household. There are two cities or communities, the ecclesia (church) and the state, and each imitate the authority of God differently.

Of these communities, the ecclesia represents the power and body of the Kingdom of God on earth. Augustine refers to the ecclesia as a figura of the heavenly city in the mundane pilgrimage. ${ }^{47}$ The ecclesia mirrors the honour and caritas of the City of God, but it cannot be equal to the Heavenly City because the ecclesia approaches the transcendental-eschatological city as a ciuitas peregrina. During this process, it contains true and false members who are intermixed and will be differentiated at the end of time; as a historical and empirical reality, the ecclesia is a corpus permixtum. At the level of faith (fides), the ecclesia is the pilgrimaging heavenly city (ciuitas caelestis peregrina). ${ }^{48}$

The state (civil society) embodies the ciuitas terrena, but these are also not the same. The state mirrors God' authority and implements a rule upon the citizens on earth, but the notion of ciuitas terrena, being a theological concept, does not refer to any specific secular organisation or state in the empirical sphere.

\footnotetext{
${ }^{47} C D$ 15.26: Procul dubio figura est peregrinantis in hoc saeculo ciuitatis Dei, hoc est ecclesiae. CD 16.2:...eius ecclesiam, quae ciuitas Dei est... CD 17.4....ecclesia Christi, ciuitas regis magni... En. Ps. 98.4:...quae est ciuitas Dei, nisi sancta Ecclesia? For the issue of whether the ecclesia could be equated with the heavenly city and the state with the earthly city, see the discussion in Ruokanen 1993, 83-96; Xia Dongqi 2007, 232-248; Weithman 2001, 234-237; Deane 1963, 172-175.

${ }^{48}$ As Miikka Ruokanen suggests, "Augustine identifies the true church, the object of faith, with civitas Dei whose king is Christ himself. As a prefigure of the city of God, the church is an eschatological reality. As an empirical, historical reality the pilgrim church, ecclesia peregrina, is corpus permixtum...Augustine discusses the mixed body of ecclesia nunc, 'the church now,' as distinct from ecclesia tunc, 'the church then,' which no longer contains any wicked persons". Ruokanen 1993, 87-88.
} 
In the fallen state, Cain established the first terrestrial city (condiderit ciuitatem), focusing the love downward to the earth and sliding into a libido dominandi; due to his cupiditas gloriae, Cain killed his brother Abel who did not establish a mundane city, but awaited the arrival of the Kingdom of God. ${ }^{49}$ In other words, while the terrestrial city imitates the authority of God, it is dominated by evil desire. Augustine states further that there were some just people in the early days, such as Seth and Noah, but their societies were still overwhelmed by the fallen power and displayed an earthborn characteristic. ${ }^{50}$ Moreover, Augustine uses the Roman Empire as an example of the ciuitas terrena, arguing that it is dominated by libido dominandi and has brought great misery and pain upon people. The Romans are proud of their achievements and have raised several heroes who have been inspired by glory. These honours have received a reward from the justice of God at the level of earthly life and their good moral characters (not genuine virtues) may be beneficial even for Christians. ${ }^{51}$ In this sense, libido dominandi may have a certain positive role in producing human glory. However, these honours or glories, Augustine observes, display pride and vice and are necessarily false when compared to the true virtues of God. ${ }^{52}$ While Augustine considered the Romans to have exhibited some civic virtue, from a Christian perspective, their political practice was vicious because it was driven by avidity for praise and by a passion for glory and domination.

\section{(3) World (orbis terrae)}

\footnotetext{
${ }^{49}$ CD 15.1: Scriptum est itaque de Cain, quod condiderit ciuitatem; Abel autem tamquam peregrinus non condidit. CD 15.7: Sed illud Dei praeceptum Cain sicut praeuaricator accepit. Inualescente quippe inuidentiae uitio fratrem insidiatus occidit. Talis erat terrenae conditor ciuitatis. Quo modo autem significauerit etiam Iudaeos, a quibus Christus occisus est pastor ouium hominum, quem pastor ouium pecorum praefigurabat Abel.

${ }^{50} C D$ 15.8:...discretio quidem, quod ambarum separatim generationes commemorantur, unius fratricidae Cain, alterius autem qui uocabatur Seth (natus quippe fuerat et ipse de Adam pro illo, quem frater occidit); concretio autem, quia bonis in deterius declinantibus tales uniuersi facti fuerant, ut diluuio delerentur, excepto uno iusto, cui nomen erat Noe, et eius coniuge et tribus filiis totidem que nuribus, qui homines octo ex illa omnium uastatione mortalium per arcam euadere meruerunt. Ruokanen maintains that any kingdom on earth is controlled by the power of the transcendental nature of the ciuitas terrena. "This is how the transcendental reality of civitas terrena makes its power concrete in the human world...Augustine would never say, however, that a certain commonwealth is actually civitas terrena. Just like civitas Dei the diabolic civitas terrena is also a transcendental-eschatological reality, and presently it is an object understood only by faith". Ruokanen 1993, 116. For related discussions, see also Xia Dongqi 2007, 240-248.

${ }^{51}$ CD 5.12-19.

${ }^{52}$ For Augustine's evaluation of Roman virtues, see CD 5.12. See also Irwin 2007, 418-433.
} 
Earthly cities and kingdoms comprise orbis terrae, in which there is either peace or warfare. The Roman Empire introduced stability to the Mediterranean world, but this was ultimately based on the Romans' desire for domination, praise, and glory. In fact, the Romans did not hesitate to die for glory. ${ }^{53}$ As Augustine observes, "This, forsooth, was the result of that vaunted eagerness for praise and passion for glory! In this way, the Romans were led to do many great deeds, first by their love of liberty, and then by their desire for praise and glory". ${ }^{54}$ Augustine quotes the prose of Sallust to express the following opinion, "For glory, honour and power are sought by good and base men alike. The former, however, strive after them by the true way, whereas the latter, because they have no good arts, seek them by means of fraud and deceit". ${ }^{55}$ The "good arts", Augustine notes, are the virtuous means for glory and power, rather than treachery. ${ }^{56}$ Augustine extends his analysis of the morality of the state to the relations between nations by adopting the same categories of moral psychology as he does in his discussion on the state. He distinguishes between two types of men related to two attitudes for dominions:

(a) Those who worship the true glory of God possess virtues from the Holy Spirit and even love their enemies, so as to correct those who resent them and forgive those who slander them and instead make them their companions. ${ }^{57}$

(b) Those who are eager for dominion lust for earthly glory and power. They desire and love luxury and mastery that surpasses even animals. ${ }^{58}$ Referring to the history of Rome, Augustine writes that with libido dominandi, they conquered their enemies' territory, but they also received the corresponding

\footnotetext{
${ }^{53}$ CD 5.12:... "laudis auidi, pecuniae liberales erant, gloriam ingentem, diuitias honestas uolebant"; hanc ardentissime dilexerunt, propter hanc uiuere uoluerunt, pro hac emori non dubitauerunt; ceteras cupiditates huius unius ingenti cupiditate presserunt.

${ }^{54}$ CD 5.12: Hoc illa profecto laudis auiditas et gloriae cupido faciebat! Amore itaque primitus libertatis, post etiam dominationis et cupiditate laudis et gloriae multa magna fecerunt.

${ }^{55}$ CD 5.12: "Nam gloriam honorem imperium bonus et ignauus aeque sibi exoptant; sed ille, inquit, uera uia nititur, huic quia bonae artes desunt, dolis atque fallaciis contendit”.

${ }^{56}$ CD 5.12: Hae sunt illae bonae artes, per uirtutem scilicet, non per fallacem ambitionem ad honorem et gloriam et imperium peruenire.

${ }^{57}$ CD 5.19: Sed qui contemnit iudicia laudantium, contemnit etiam suspicantium temeritatem, quorum tamen, si uere bonus est, non contemnit salutem, quoniam tantae iustitiae est qui de spiritu Dei uirtutes habet, ut etiam ipsos diligat inimicos, et ita diligat, ut suos osores uel detractores uelit correctos habere consortes non in terrena patria, sed superna.

${ }^{5}$ CD 5.19: Qui autem gloriae contemptor dominationis est auidus, bestias superat siue crudelitatis uitiis siue luxuriae.
} 
resistance. Even if their rule brought some earthly benefits to their citizens through God's providence, frequent wars brought fatigue and catastrophe. Rather than these conquests bringing benefits and happiness, the vast imperial territory that sacrificed innumerable lives became a tremendous burden. Furthermore, the Romans may be rewarded according to the light of the earthly city, but they lost their citizenship in the Heavenly City. ${ }^{59}$ Augustine concludes that those who serve human honour without piety have neither true glory nor virtues, but are instead dominated by their vicious desire for power (dominandi libido dominatur). In contrast, those who achieve the happiest life are those who are gifted with true godliness and who apply their power to benefit human affairs through God's mercy. ${ }^{60}$ These two types of people are mixed, showing their own values of honour in the earthly state.

As we see, in the historical picture of the evolvement of the two cities, Augustine focuses on the role of self-love and regards it as the hallmark of the Fall. The two distinguished loves, caritas and cupiditas, are the cornerstones of two cities, manifesting distinct tendencies and appearances on the three levels of household, city, and world. In a perverted way, the human cupiditas mirrors divine love, and the passion for domination and glory turns the divine authority into an authority of sinners who exercise their self-chosen autonomy in their quest for domination. This misguided imitation and the intermingled reality of two types of citizens within one society (corpus permixtum) result in a complex, opaque morality and politics. The members of the two cities harbour both good and bad intentions. Even the believers have sinful inclinations. However, the theological difference between the essences of the two cities is still apparent in the interwoven state, the future heavenly citizens being temporal residents in this world. Due their fallen nature, they cannot eliminate the shadow of "self-love" in their pursuit of a peaceful life in accordance with the natural order or in their attempt to embody the

\footnotetext{
${ }^{59}$ CD 5.18-19: ... ut non pro terrenis et temporalibus beneficiis, quae diuina prouidentia permixte bonis malisque concedit, sed pro aeterna uita muneribusque perpetuis et ipsius supernae ciuitatis societate colatur Deus unus et uerus...eos tamen, qui ciues non sint ciuitatis aeternae, quae in sacris litteris nostris dicitur ciuitas Dei, utiliores esse terrenae ciuitati, quando habent uirtutem uel ipsam, quam si nec ipsam.

${ }^{60}$ CD 5.19: ...qui uera pietate praediti bene uiuunt, si habent scientiam regendi populos, nihil est felicius rebus humanis, quam si Deo miserante habeant potestatem. CD 14.28: Illi in principibus eius uel in eis quas subiugat nationibus dominandi libido dominatur; in hac seruiunt inuicem in caritate et praepositi consulendo et subditi obtemperando.
} 
principle of caritas in their family and broader communities. Thus, Augustine's social theory addresses the question of how to control perverse concupiscence and avoid libido dominandi. I shall next examine Augustine's approach to this question at the levels of domus, ciuitas and orbis terrae.

\subsection{Sexuality, Marriage and Virginity}

Some critics maintain that Augustine holds a negative attitude toward sexuality. As a consequence, Augustine proposes an ascending ranking for the merits of marriage, widowhood and consecrated virginity based on their distance from concupiscence, which is rooted in the tradition of asceticism. Some other scholars are of the opinion that Augustine shifts his emphasis from asceticism to inner moral evaluation in accordance with the grade of humility rather than external factors. Let us now address these competitive positions.

Drawing on the controversy between Augustine and Julian, Mathijs Lamberigts maintains that Augustine is firmly in line with the ascetic tradition of his predecessors who proposed that marriage is inferior to abstinence, as marriage involves concupiscentia, which for Augustine was a sin after the Fall. ${ }^{61}$ Lamberigts stresses that in Augustine's opinion, it would be better to be without sexual desire with the one exception being procreation: ${ }^{62}$ "It seemed to make more sense to Augustine that a person should make a radical break with sexual desire, rather than make proper use of it within marriage... Sexual desire was something to be avoided at all costs, rather than exploited, however legitimately". ${ }^{63}$ Lamberigts elaborates on sexual desire, emphasising that it is evil (malum) because it is not devoted to God, but to a human's will. This means that Augustine

\footnotetext{
61 "...to his own experience with sexuality, which was firmly rooted in the traditional conviction that the choice of marriage was inferior to a life of abstinence". Mathijs Lamberigts, "A Critical Evaluation of Critiques of Augustine's View of Sexuality", in Augustine and his Critics, ed. Robert Dodaro and George Lawless (London and New York: Routledge, 2000), 186.

62 "...such concupiscentia certainly cannot be good and, as such, it would be better neither to make use of it nor to 'know' it than to use it properly for the sake of procreation'. Lamberigts 2000, 187. Mathijs Lamberigts understands concupiscentia as sexual desire, while John Rist considers it to be less than an active attitude, "a defect in man which is the effect of sin, the permanent weakness which we have inherited from Adam" (Rist 1994, 136). Timo Nisula similarly thinks that it is a "reigned sin" or "a tamed and defeated enemy" (Nisula 2012, 311-313). I think that in Augustine's view, concupiscentia as a faculty was created by God but after the Fall, it shows disobedience and sinful state. See Augustine's discussions of the sexuality in paradise in $C D$ 14.17-26.

${ }^{63}$ Lamberigts 2000, 186.
} 
rejected any expression of sexuality save for procreation. Thus, forms of expression such as sexuality outside marriage, sexuality with one's spouse for lust, or any indulgence in sexual pleasure, was unacceptable for Augustine. ${ }^{64}$ Procreation alone is a permitted act, for which "the filth of marriage" could be forgiven. ${ }^{65}$ Lamberigts adds that Augustine's vision of marriage and virginity was influenced by several examples of asexual marriages (Paulinus and Therasia, Turcius Apronianus and Avita, etc.) as well as the ascetic practices of his time and this led to his preferential evaluation of continence that was also influenced by $\mathrm{St}$ Paul (especially 1 Corinthians 7). ${ }^{66}$ Thus, Lamberigts concludes that Augustine provides a grading on marriage and continence, granting the highest regard for the life of Christian abstinence and reluctantly accepting sexuality in marriage. ${ }^{67}$

Patrick Gerard Walsh makes a similar observation, arguing that for Augustine, the merit of virginity ranks above marriage and married people will attain a lesser reward than the consecrated virgins in heaven. ${ }^{68}$ In his introduction to Augustine's De bono coniugali and De sancta uirginitate, Walsh suggests various factors that might have influenced Augustine's alignment of different living modes: (1) Early Christian asceticism influenced Augustine through some of his predecessors, such as Tertullian, Cyprian, and Ambrose. Augustine frequently adopts their ascetic ideal and virgin worship in his treatises (such as Tertullian's rigorous asceticism, Cyprian's notion of a virgin's greater honour in heaven, and Ambrose's vision of Mary as a perfect virgin); ${ }^{69}$ (2) Paul's counsel to the married and unmarried had a profound impact on Augustine. Paul expresses his preference for celibacy over marriage, especially in 1 Cor. 7:3ff and 1 Cor. 7:25ff, which serve as the scriptural basis for Augustine's argument in De bono

\footnotetext{
${ }^{64}$ Lamberigts 2000, 186-187.

${ }^{65}$ Lamberigts 2000, 187.

${ }^{66}$ Ibid., 186.

67 “....Augustine had the highest regard, at least on this question, for a life of Christian abstinence, within or without marriage...Augustine and his contemporaries, however, did not believe in sexuality as an enriching factor in the marriage relationship. He was firmly rooted in a tradition partly confirmed by the Bible - in which the satisfaction of sexual desires as an end itself was rejected". Ibid., 187-188.

68 "Marriage is a good [XIII] because of its threefold attributes of proles, fides, sacramentum, but these are human goods, whereas consecrated virginity rises above them to angelic heights, ensuring for virgins greater distinction in heaven”. Walsh 2001, xxvi.

${ }^{69}$ Walsh 2001, xvi-xvii.
} 
coniugali and De sancta uirginitate $;^{70}$ (3) Manichaean condemnation of marriage results in the converted Augustine developing a theological interpretation of sexuality in marriage that refutes Manichaean asceticism. A series of works by Augustine against Manichaeanism ${ }^{71}$ are evidence for Augustine's re-evaluations of the (good) meaning of marriage as well as its connections to renunciation; and (4) To respond to the controversy caused by the biased positions between Jovinian and Jerome, Augustine developed a comprehensive theological stance. Factors that contributed to Augustine's ladder of goodness, virginity above marriage, are a positive evaluation of marriage (Jovinian) as well as the superiority of virginity (Jerome). ${ }^{72}$ Walsh concludes that Augustine's position was that "marriage was a good, but consecrated virginity was better" ${ }^{73}$

In contrast to Lamberigts and Walsh, George Lawless focuses on Augustine's thoughts on morality rather than virginity. Lawless observes that Augustine shifts his emphasis from marriage and virginity to humility. ${ }^{74}$ In his discussion on the different ascetic lifestyles and the cult of perfectionism during the fourth and fifth century, Lawless notes that Augustine exhibits a decentering tendency that moves away from asceticism. Augustine rejects the austere ascetic strategies of his time. ${ }^{75}$ In addition, Augustine avoided perfectionism and elitism in his approach against Manichaeanism, Pelagianism, and Donatism. ${ }^{76}$ Nonetheless, when Augustine cites the Pauline source for the position that

\footnotetext{
${ }^{70}$ Walsh 2001, xv-xvi.

${ }^{71}$ In addition to De bono coniugali and De sancta uirginitate, Walsh lists Augustine's treatises against Manichaeanism during 388-400, such as De Genesi adversus Manichaeos, De moribus Manichaeorum, Contra Fortunatum, Contra epistolam Manichaei quam uocant fundamenti, and Contra Faustum Manichaeum. Walsh 2001, xviii.

72 "Though he [Augustine] was anxious to emphasize that Jovinian and his followers were the main target in his analyses of marriage and virginity, he sought also to dispel the resentment among the married laity caused by Jerome's uituperatio nuptiarum in his disastrous foray into the controversy". Walsh 2001, xx.

${ }^{73}$ Walsh 2001, xxx.

74 "In virtually every instance, the bishop deliberately shifted the emphasis from virginity and marriage to humility and pride, to the extent that even his readers, as he himself acknowledges, were justified in thinking that they were reading a treatise on humility rather than virginity". Lawless 2000, 154.

75 'Both the perfectionism required for a 'servant of Christ' by Jerome, and his idealisation of the Syrian desert near Chalcis as the type of place most suitable for the practice of asceticism, would have been as unacceptable to Augustine... who refused to join him [Jerome] in his austere ascetic exercises... No comparable extreme can, to my knowledge, be cited for Augustine; nor does he ever urge such a rigorous regimen upon anyone". Lawless 2000, 144-145.

76 "Augustine's much favoured 'wheat and chaff' metaphor is as anti-Manichaean (elect versus hearers), and anti-Pelagian (elitist versus non-elitist) as it is anti-Donatist (saints versus sinners)". Ibid., 152.
} 
virginity is superior to marriage in 1 Cor. 7 (for example, bene facit/melius facit), he also states that, "marriage with humility is better (melius) than virginity with pride". ${ }^{77}$ Based on a scale of humility, Augustine provides a hierarchical alignment of marriage, widowhood, virginity, and martyrdom, with all these lifestyles being gifts of God. ${ }^{78}$ As Augustine's parable (Serm. 304.3) illustrates, "a single garden in which were found not only the roses of the martyrs but also the lilies of the virgins, the ivy of married couples and the violets of widows". ${ }^{79} \mathrm{On}$ this basis, Lawless does not assume that there is any order of merits between these lifestyles, but what Augustine expressed is rather a moral scale on the various gifts of God.

Two treatises are important in the above context, De bono coniugali and De sancta uirginitate, but late works, such as De nuptiis et concupiscentia and Contra Iulianum, are also relevant. Scholars correctly detect in Augustine's position on sexuality and continence various traditions of asceticism. Yet there are different interpretations of Augustine's concept of "merits" and this results in divergent opinions on whether the conjugal, widows, and virgins indeed have different levels of "merits". One controversial question is Augustine's percentage analogy in De sancta uirginitate 46, where he asks whether the virginal life represents fruit a hundredfold, the widow's life sixtyfold, and that of the married thirtyfold:

Whether the virgin's life represents fruit a hundredfold, the widow's life sixtyfold, and married life thirtyfold. Or alternatively, whether fruitfulness a hundredfold is to be assigned rather to martyrdom, the sixtyfold to continence, and the thirtyfold to marriage...Or what seems to me more likely, since the gifts of divine grace are many, and one is greater and better than another (hence those words of the Apostle, 'Strive for the greater gifts')...In the first place, we must not assess a widow's continence as bearing no fruit, or relegate it to the merits of married chastity, or equate it with the glory of the virgin... ${ }^{80}$ [transl. P. G. Walsh]

\footnotetext{
${ }^{77}$ Ibid., 154.

${ }^{78}$ Ibid., 155.

${ }^{79}$ Ibid., 157. Cf. Serm. 304.3.2: Habet, habet, fratres, habet hortus ille dominicus, non solum rosas martyrum, sed et lilia uirginum, et coniugatorum hederas, uiolasque uiduarum.

${ }^{80}$ s. uirg. 46: siue uirginalis uita in centeno fructu sit, in sexageno uidualis, in triceno autem coniugalis; siue centena fertilitas martyrio potius inputetur, sexagena continentiae, tricena conubio...siue, quod probabilius mihi uidetur, quoniam diuinae gratiae multa sunt munera et est aliud alio maius ac melius (unde dicit apostolus: Imitamini autem dona meliora)...Primum, ne
} 
Augustine seems to offer a contradictory picture. On the one hand, abstention from sexuality is better than intercourse during marriage and abstention will lead to achieving greater merits and gift. This means that the fruit of consecrated virginity is greater than that of marriage ${ }^{81}$ On the other hand, this alignment of merits does not exist because a person occasionally has fewer merits, but could nevertheless receive more rewards from God. ${ }^{82}$ This relation between merit and reward is emphasised further by Augustine in his late works as he highlights the issue of grace and renewal. Concerning the different polemists in various periods, such as Manichaeans, Jovinian, and Donatists, Augustine's emphasis on the issue of asceticism and virginity varies, but he makes important adjustments during the Pelagian debate. For instance, in Retractationes and De nuptiis et concupiscentia, Augustine continues to rectify the viewpoints of both Jovinian and Jerome by arguing that marriage is good and that consecrated virginity is rightly preferred to marriage. However, Augustine soon shifts the scope to faith and renewal, emphasising that there is no true virginity or chastity except that in true faith. ${ }^{83}$ Here grace, free will, baptism, and renewal are featured more prominently than in his early debate that compared the qualities of chastity and virginity. Augustine develops a more accurate theological anthropology, involving more subjects than he had in his previous controversies, especially in his debate with Julian (418430). Rather than adhere to historical order, I shall begin with the two stages of Augustine's anti-Pelagian works ${ }^{84}$ to evaluate his concept of "merit" as well as his

continentiam vidualem aut in nullo fructu constituamus aut ad coniugalis pudicitiae meritum deponamus aut uirginali gloriae coaequemus.

${ }^{81}$ b. coniug. 6: Ac per hoc melior est quidem ab omni concubitu continentia quam uel ipse matrimonialis concubitus, qui fit causa gignendi. Sed quia illa continentia meriti amplioris est.

${ }^{82}$ s. uirg. 46: et aliquando alter fructuosus est donis paucioribus sed potioribus, alter inferioribus sed pluribus.

${ }^{83}$ See Retr. 2.53 and nupt. et conc. 1.3-5. In nupt. et conc. 1.5, Augustine maintains, "There is, then, no true chastity, whether conjugal, or vidual, or virginal, except that which devotes itself to true faith. For though consecrated virginity is rightly preferred to marriage, yet what Christian in his sober mind would not prefer Catholic Christian women who have been even more than once married, to not only vestals, but also to heretical virgins?" [transl. Holmes]

${ }^{84}$ The Pelagian debate took place in two stages. During the first stage (411-418), against Pelagius and Caelestius, the issues of grace and nature, merits and baptism, perfection and original sin, were discussed in general terms in treatises such as De peccatorum meritis et remissione (411/2), De spiritu et littera (412), De natura et gratia (415), De perfectione iusticia hominis (415), De gestis Pelagii (416/7), De gratia Christi et peccato originali (418). During the second stage (418-430), when Julian of Eclanum emerged as a main opponent, a more detailed discussion was conducted in Augustine's De nuptiis et concupiscientia (419/20), De anima et eius origine (419), Contra duas epistolas Pelagianorum (420), De gratia et libero arbitrio (426/7), De correptione et gratia 
percentage ranking of marriage and virginity in De bono coniugali and De sancta uirginitate.

\section{(1) Grace and the renewal of concupiscentia}

In the early Pelagian debate, Augustine analyses concupiscentia in the context of Pauline theology, concentrating on the conceptions of original sin and grace in the renewal of concupiscence. To address the objection to infant baptism and the heritage of Adam's sin undertaken by Pelagius and Caelestius, Augustine argues in the first book of De peccatorum meritis et remissione that the first man's sin passes on to all men by natural descent and that this causes the punishment of bodily death. By citing Paul's First Letter to Corinthians, Augustine states that in reality, all men follow Adam who transgressed the commandment by disobedience. This sinful disobedience is transmitted through propagation rather than imitation, and thus, all have sinned in Adam, even infants. ${ }^{85}$ Likewise, the renewal does not occur by external imitation, but by inner works through grace. Augustine explains that the Apostle Paul observes that the saints accepted Christ and His grace dwelled within them and led to illumination, righteousness, and obedience. Through baptism, they were infused with grace, which helps them to control the disobedience of their flesh and their hidden carnal concupiscence. This applies to baptised infants as well. ${ }^{86}$ Thus, Augustine holds that it is necessary to baptise infants because the original sin is inborn and the renewal of grace acts inside. Augustine explains in the second book of De peccatorum meritis et

(426/7), De praedestinatione sanctorum (428/9), De dono perseuerantia (428/9) as well as two long works Contra Iulianum (421/22) and Contra Iulianum opus imperfectum (429/30). For Augustine's anti-Pelagian controversy and treatises, see Karfíková 2012, 159-211; 297-336; Dominic Keech, The Anti-Pelagian Christology of Augustine of Hippo, 396-430 (Oxford: Oxford University Press, 2012), 14-19; 40-68; 86-100.

${ }^{85}$ In pecc. mer. 1.10, Augustine observes, "No doubt all they imitate Adam who by disobedience transgress the commandment of God...'By one man,' says he [Paul], 'sin entered into the world, and death by sin.' This indicates propagation, not imitation; for if imitation were meant, he would have said, 'By the devil.' But as no one doubts, he refers to that first man who is called Adam: 'And so,' says he, 'it passed upon all men'”. [transl. Holmes] Augustine argues that the Pelagian use of "imitation" would exonerate human generations from the original sin and identify Adam's Fall as a passive personal mistake due to the temptation of the devil. He therefore believes that the Pelagian doctrine of "imitation" actually ascribes the fault of the Fall to the devil rather than to Adam.

${ }^{86}$ See pecc. mer. 1.9-10. For baptism and original sin in Augustine, see William Harmless, S.J., "Baptism", in Augustine through the Ages: An Encyclopedia, ed. Allan D. Fitzgerald (Michigan/Cambridge: Eerdmans, 1999), 84-91. 
remissione that infants are born with evil concupiscence due to the Fall and only the baptised infants are saved from condemnation. ${ }^{87}$ After these infants reach adulthood, they should refuse to consent to the temptation of concupiscence through their own free will, but this renewal of free will is based on God's assistance. $^{88}$

Pelagius and Caelestius provide a different theological account of original sin, nature, and grace. They reason that Adam's individual sin cannot be transmitted to his offspring by natural descent. The assumption is that offences committed by offspring imitate the first man's demerit of sin. However, this does not occur through propagation, so original sin is therefore a nullity. ${ }^{89}$ Pelagius and Caelestius claim that nature was neither corrupted nor distorted by sin because it was created as something good by the blameless Creator. ${ }^{90}$ As a consequence, humans have access to unspoiled nature and the complete power of their free will to achieve their own justification without the grace of Christ. ${ }^{91}$ They thus argue that concupiscence is found in both baptised and unbaptised humans, but the flesh and the spirit are both good works of God and the conflict between motives is meant to be resolved by the will. ${ }^{92}$

Augustine criticises Pelagius for attributing too much importance to the act of human will and for neglecting the radical need for grace. At the end of $D e$ natura et gratia, Augustine quotes the following passage from Romans: "For the good that I would, I do not; but the evil which I would not, that I do" (Rom. 7:19). Augustine contemplates whether it is not the punishment for sins that accounts for

\footnotetext{
${ }^{87}$ pecc. mer. 2.4: "Concupiscence, therefore, as the law of sin which remains in the members of this body of death, is born with infants. In baptised infants, it is deprived of guilt, is left for the struggle [of life], but pursues with no condemnation, such as die before the struggle. Unbaptised infants it implicates as guilty and as children of wrath, even if they die in infancy, draws into condemnation". [transl. Holmes]

88 pecc. mer. $2.4-5$.

${ }^{89}$ pecc. mer. 1.15 .

${ }^{90}$ nat. et gr. 21. Grace seems to be subtly acknowledged by Pelagius since he argues that being good works of God, humans and the nature cannot be depraved (nat. et gr. 11-12), but in a deeper sense, Augustine reveals, Pelagius and Caelestius never really acknowledge grace. See gr.et pecc. or. 1.31 .

${ }^{91}$ As Augustine states in nat. et gr. 58: "By our author, however, it is maintained that our human nature actually possesses an inseparable capacity of not at all sinning. Such a statement...causes the grace of Christ to be 'made of none effect,' since it is pretended that human nature is sufficient for its own holiness and justification". [transl. Holmes] For his detailed discussion on Pelagius's view of human will and nature, see nat. et gr. 53-59.

92 nat. et gr. 60.
} 
humans not having free determination of their will to choose what they are willing to do or refrain from erroneous involuntary carnal habit such as lusts. ${ }^{93}$ This indicates that human free will is weakened and has lost control of capacities, with human nature being tarnished by a sinful quality. Therefore, the whole discussion with the Pelagians, Augustine maintains, centres on the point of grace and its function in renewing a perverted nature. ${ }^{94}$ In the fallen state, men easily succumb to the temptation of concupiscentia carnis and they habitually consent to unwholesome sexual suggestions. However, the love of grace, when poured into their heart, provides crucial aid to improve their control over their sexual passions in accordance with righteousness. This renewal, Augustine believes, is attained through faith, leading Christians to virtuous actions and a holy life. ${ }^{95}$ Thus, Augustine attributes the therapy of concupiscentia to the mercy and grace of God through the faith.

\section{(2) Obedience and free choice of will}

To avoid over-emphasising the liberty of the human will, Augustine reinforces the discussion on grace and free will, faith and merits at the second stage of the Pelagian controversy. ${ }^{96}$ In his first letter (Ep. 214) to Valentinus and the monks of Hadrumetum, Augustine advocates the interpretation that the will is free because otherwise humans could not exercise obedience. However, free will is assisted by the grace of God, and without grace, the will cannot turn towards God. Augustine then reasons in the second letter ( $E p .215)$ that grace will direct one's steps to the straight path and to peace according to the mercy of God. Free will is not dispensable here, but it is prepared and assisted by grace. ${ }^{97}$ These two letters serve

\footnotetext{
93 nat. et $\mathrm{gr} .81$.

${ }^{94}$ nat. et gr. 81: "Our whole discussion with them on this subject turns upon this, that we frustrate not the grace of God which is in Jesus Christ our Lord by a perverted assertion of nature...we ourselves likewise were by nature children of wrath, even as others". [transl. Holmes]

${ }^{95}$ nat. et gr. 82: "We must first of all exhort them to that faith whereby they may become Christians, and be subjects of His name and authority, without whom they cannot be saved. If, however, they are already Christians but neglect to lead holy lives, they must be chastised with alarms and be aroused by the praises of reward". [transl. Holmes]

${ }^{96}$ In Retr. 2.66, Augustine states that the background of his composing of De gratia et libero arbitrio is to respond to the monks of Hadrumetum and the Pelagians who defend the freedom of the will and neglect grace. This treatise and the related work De correptione et gratia were composed at the same period around the year 426 or 427.

${ }^{97}$ Letter II [Ep. 215], ch. 5: "Now consider, my brethren, that in these words of Holy Scripture, if there were no free will, it would not be said, 'Make straight paths for thy feet, and order thy ways;
} 
as a brief introduction to his position in De gratia et libero arbitrio.

On the issue of grace and free will, Augustine refutes two tendencies: (i) the defence of man's free will without the assistance of grace. (ii) The defence of God's grace denying man's free will. ${ }^{98}$ At the beginning of De gratia et libero arbitrio, Augustine states that the will was created before the Fall and would it have obeyed God's commandments, it would have not been weakened. However, it succumbed to sin through the free choice of the forbidden fruit. When the obedient state of the flesh was lost in Paradise, the consequence of the sinful disobedience in the fallen state is the spontaneous autonomy of the concupiscence that requires continuous control by the will. However, the ability to resist the temptation of concupiscence often fails because the will consents to things that it primarily does not will to do. It is therefore impossible to make the evil desire (such as concupiscence) obey chastity without the aid of God's grace. ${ }^{99}$ At the same time, Augustine lists numerous quotations from the Old and the New Testament to illustrate that God's commandments are supposed to be followed by the human will, such as "be not like a horse or a mule, which have no understanding", "peace on earth to men of good will", and "if I do this willingly, I have a reward". ${ }^{100}$ At the end of De gratia et libero arbitrio 4, Augustine states the following in Rom. 2:12: "He shall reward every man according to his works" in order to remind us that the acts of the will in accordance with God's law will eventually be rewarded by Christ and one's own will should not be detracted. ${ }^{101}$

Augustine's point is clarified in the latter part of De gratia et libero

turn not aside to the right hand, nor to the left.' Nor yet, were this possible for us to achieve without the grace of God, would it be afterwards added, 'He will make thy ways straight, and will direct thy steps in peace"". [transl. Holmes]

${ }^{98} \mathrm{gr}$. et lib. arb. 1: "But seeing that there are some who so defend God's grace that they deny man's free will, or who think that free will is being denied when grace is defended, I have taken care". [transl. Russell]

${ }^{99}$ gr. et lib. arb. 8.

${ }^{100} \mathrm{gr}$. et lib. arb. 4.

${ }^{101}$ See gr. et lib. arb. 4: "No man, therefore, when he sins, can in his heart blame God for it...Nor does it detract at all from a man's own will when he performs any act in accordance with God...may the reward of a good work be hoped for from Him concerning whom it is written, 'He shall reward every man according to his works"'. [transl. Holmes] Augustine stresses that our love for God is preceded by God's gift of love (voluntas praeparatur a Deo). Augustine assumes that this is compatible with free will, but the issue remains a problem in his thought. See Rist 1994, 180; Eleonore Stump, "Augustine on free will", in The Cambridge Companion to Augustine, ed. Eleonore Stump and Norman Kretzmann (Cambridge: Cambridge University Press, 2001), 136139; A. Sage, "Praeparatur voluntas a Deo", in Revue des études Augustiniennes 10 (1964), 1-20. 
arbitrio. He stresses the importance of free will in conversion, and maintains that it is radically aided by grace. In short, it is God who is able to soften the stony heart and convert the depraved will to accept the faith. Faith is thus a gift of God, as Augustine maintains:

God, then, works in us, without our cooperation, the power to will, but once we begin to will, and do so in a way that brings us to act, then it is that He cooperates with us. But if He does not work in us the power to will or does not cooperate in our act of willing, we are powerless to perform good works of a salutary nature. ${ }^{102}$ [transl. Russell]

This prepared will (offered by grace) begins to turn toward God, but initially, it is feeble and weak. However, the will may become greater and robust in cooperation with God. ${ }^{103}$ In the case of martyrs, their faith matured, displaying free will with great love that is obedient to the divine commandments. These were gifts of God rather than their own merits because a good will requires the right orientation and the power of application, and these two aspects are a consequence of God's grace. ${ }^{104}$ Therefore, the conversion of the will from evil to good, or from disobedience to obedience, includes the freedom to improve, but merits are the fruits of grace.

\section{(3) Habits and virtues of passions}

Augustine's anti-Julian treatise, De nuptiis et concupiscentia, compares Christian and non-Christian behaviour in terms of concupiscence. Augustine argues that grace will aid the baptised in cultivating good habits and resisting their disobedient sexual desires. These are the virtues of passions. ${ }^{105}$ In other words, Augustine asserts that the regenerated mind will not easily yield to evil suggestions. This means that the struggle between the flesh and the spirit will be regularly considered in one's mind and it is here that the will that is influenced by grace displays its ability to resist the suggestions of evil desires. As a consequence, sexual passions gradually diminish, and love (poured by grace) increases. Due to

\footnotetext{
$102 \mathrm{gr}$. et lib. arb. 33. Ut ergo uelimus, sine nobis operatur; cum autem uolumus, et sic uolumus ut faciamus, nobiscum cooperatur: tamen sine illo uel operante ut uelimus, uel cooperante cum uolumus, ad bona pietatis opera nihil ualemus.

${ }^{103}$ gr. et lib. arb. 33.

${ }^{104} \mathrm{gr}$. et lib. arb. 31. Ut homo qui uoluerit et non potuerit, nondum se plene uelle cognoscat, et oret ut habeat tantam uoluntatem, quanta sufficit ad implenda mandata... Tunc enim utile est uelle, cum possumus; et tunc utile est posse, cum uolumus.

${ }^{105}$ nupt. et conc. 1.25 .
} 
the Fall, all humans have evil movements of concupiscence, but renewed Christians will not commit sins if they do not follow the suggestion-in this case, concupiscence is not regarded as a personal sin. ${ }^{106}$ Furthermore, after addressing these issues for a long time, married Christian couples will develop good habits in using the passions and virtues of their mind as the corresponding fruits will be cultivated. On the contrary, those who refuse grace and pursue sexual pleasures (other than for procreation) will witness their lust taking an upper hand. Indeed, lusts will induce them to indulge in prurient activities, such as adultery and fornication, thus making them the slaves of evil passions. Obscenity thus occupies their mind and acts as a king. ${ }^{107}$

Augustine cites examples of a harlot, a conjugal partner, a widow, and a virgin in Contra Iulianum 6.55 to demonstrate that the more one yields to concupiscence by habit, the greater the efforts required to convert the evil passions into good use. ${ }^{108}$ Augustine claims that a harlot's sexual inclination leads her to indulge in lust more easily than that of a consecrated virgin who has no sexual experience. Similarly, lascivious sexual habits in marriage also destroy the conjugal chastity and result in prurient indulgences. Augustine thus emphasises that habituation to the evil of concupiscence will lead people into a bad moral state and will separate them from the Kingdom of God. ${ }^{109}$ Therefore, the great evil power of habitual concupiscence should be conquered by the attractive sweetness of the goodness which is God's grace. ${ }^{110}$ In brief, Augustine advocated developing

\footnotetext{
${ }^{106}$ nupt. et conc. 1.25 . "In the case, however, of the regenerate, concupiscence is not itself sin any longer...this guilt [concupiscence], by Christ's grace through the remission of all sins, is not suffered to prevail in the regenerate man, if he does not yield obedience to it whenever it urges him to the commission of evil. As arising from sin, it is, I say, called sin, although in the regenerate it is not actually sin". [transl. Holmes] Augustine states that marital sexual desire (concupiscentia nuptialis) for procreating is not a sin (Ep. 6.5-8); it seems to be a legitimate use of the damaged concupiscible part of the soul. See Rist 1994, 323. See also my discussions on first movements in Chapter 3.1.

${ }^{107}$ nupt. et conc. 1.13.

${ }^{108}$ c. Iul. 6.55: Unde etiam contra istam genitalium concupiscentiam, quae ingenita nobis est per originale peccatum, uehementius uidua quam uirgo; uehementius meretrix quando casta esse uoluerit, quam quae semper fuit casta, confligit: et tanto amplius in ea superanda uoluntas laborabit, quanto maiores ei consuetudo uires dedit.

${ }^{109}$ c. Iul. 6.55: Ex isto et cum isto hominis malo nascitur homo: quod malum per se ipsum tam magnum est, et ad hominis damnationem atque a regno dei separationem tantum habet obligationis.

110 The concept of "good concupiscence" (bona concupiscentia) is introduced in Ep. 118, in which Augustine refers to it as a good longing for the sweetness of goodness. As a love of that love (dilectionis dilectio), it has been hidden in one's heart by God as a gift that provides more
} 
various living habits and virtues of passion by practicing continence, chastity, virginity, and martyrdom.

In the above account of the "grace-obedience-habit", we have seen that Augustine shifts the discussion on concupiscence and continence to the context of renewal and grace, emphasising the role of faith and baptism in the therapy. To refute the sinlessness doctrine of Julian and the Pelagians, Augustine refers to concupiscentia, the innate evil affection in the corrupted humanity as the law of sin. ${ }^{111}$ Augustine also distinguishes between three phases of renewal with the first being grace, which has the complete authority in the preparation of salvation without any human initiative. To Augustine, only grace is able to heal a corrupted human nature as well as a depraved human will (disobedient free will). Grace also pours love into the human heart, resulting in conversion and faith. Augustine also proposes that during the second phase, the human will cooperate with grace in opposing concupiscence. This is in an interior struggle between the flesh and the spirit. Eventually, this struggle will produce various good moral qualities and virtues of passions, such as conjugal chastity and virginity as the fruits of the third phase. ${ }^{112}$

This further clarifies Augustine's percentage analogy in De bono coniugali and De sancta uirginitate. By comparing the merit of married chastity (coniugalis pudicitiae meritum) with that of the widow and virgin, Augustine attributes various degrees of fruits to God's love of grace. He states that the future diverse rewards in the Kingdom of God will remain as free gifts, not given according to human merits. In fact, Augustine maintains that there is no true virginity or chastity in this life, but this does not imply that the fruits of these modes of life can be regarded as equal. He explains this at the end of De natura et gratia:

attractive sweetness to compete evil concupiscence. Ep. 118(8).3: Laudabilis est ista concupiscentia, non damnabilis. Non de hac dictum est: Non concupisces, sed de illa qua caro concupiscit aduersus spiritum. De hac autem bona concupiscentia qua concupiscit spiritus aduersus carnem. For a discussion on Augustine's bona concupiscentia, see Karfíková 2012, 254257; Nisula 2012, 309 (n. 173).

${ }^{111}$ c. Iul. 6.53. "Concupiscence does not remain in the manner of a substance, a kind of body or spirit; it is an affection, an evil quality, like sickness". [transl. Schumacher] Cf. nupt. et conc. 1.28. 112 These are not Aristotelian virtues of feeling an emotion well. Psychologically speaking, they are states of reduced sexual desire and powers to repel initial sexual impulses as soon as possible. From an Aristotelian perspective, these are cases of encracy rather than virtues. See Risto Saarinen, Weakness of Will in Renaissance and Reformation Thought (Oxford: Oxford University Press, 2011), 25; Aristotle, Nicomachean Ethics VII.7. 
Inchoate love, therefore, is inchoate holiness; advanced love is advanced holiness; great love is great holiness; "perfect love is perfect holiness,"- - but this "love"... which in this life is then the greatest, when life itself is contemned in comparison with it. ${ }^{113}$ [transl. Holmes]

No one can equal this perfect love (of God), but this true love "by the Holy Spirit who is given to us" (per Spiritum Sanctum qui datus est nobis) pours into this life, cultivating it in various grades that form an increasing process of incipient, advanced, and profound love. Virtues that control passions righteously are therefore conjugal chastity, virginity, and martyrdom. In this sense, it is evident that the proportion of "merit" constitutes the ladder of love. And the perfect grace bestows to those who cultivate their good moral habits and their spiritual renewal with respect to their emotions.

This conception of the ascent of love and the moral improvement of passions led by grace originates from the theological renewal tradition rather than in a programme of exterior asceticism. Lamberigts and Walsh astutely note that Augustine echoes the Pauline alignment of marriage and virginity based on the distance from concupiscentia, but the authors draw the misleading conclusion that Augustine follows the tradition of asceticism in ranking the merit of virgins above those who are married. This ranking according to outward human merits is rejected by Lawless, as he argues that Augustine distances himself from asceticism and that Augustine considers marriage, virginity, and martyrdom to be gifts from God. Nonetheless, Lawless does not sufficiently consider how these are cultivated habits and constitute various virtues of renewed passions that indicate a moral ascent of love led by the Holy Spirit. In Augustine's discussion, grace is the perfect holiness and perfect love whose influence creates rightly ordered souls and communities. However, facing the Donatist austere monastery elitism and the church's tendency towards secularism as well as addressing the collision between monastic spirituality and secular solicitudes are still important issues for Augustine.

\subsection{Monastery, the Church and the State}

\footnotetext{
113 nat. et gr. 84: Caritas ergo inchoata inchoata iustitia est; caritas prouecta prouecta iustitia est; caritas magna magna iustitia est; caritas perfecta perfecta iustitia est, sed caritas...quae tunc maxima est in hac uita, quando pro illa ipsa contemnitur uita.
} 
From the time of his conversion, Augustine sought refuge and freedom from emotions in his spirituality and this includes him cherishing a monastic ideal. ${ }^{114}$ Towards this end, he composed rigid rules to support monks and nuns in their meditative monastic life. With the expansion of the church in the Empire, two distinct tendencies became increasingly prominent. The first is that the fanatical Donatists grew stronger and subsequently advocated the ascetic ideal of monastery elitism as opposed to the secularity of the church. The second is that many Catholic clergies were more interested in secular powers and preferred to be involved in the daily affairs of civil administration rather than participate in monastic meditations. ${ }^{115}$ Let us now turn to examine Augustine's attitude towards these two tendencies.

\section{Ordinate love and the spiritual renewal of emotions}

Augustine's monastic ideas were formulated before his conversion in Milan. He was provided an impetus from the story of Antony of Egypt as well as the moderate asceticism of Neoplatonism and Stoicism. ${ }^{116}$ Being a monk-bishop since 395, Augustine actively built monasteries, wrote monastic rules and inspired others to do the same. ${ }^{117}$ The primary principle of Augustinian rules is that the

\footnotetext{
${ }^{114}$ Lawless maintains that Augustine's transition from secularism to asceticism and then monasticism is imperceptible rather than abrupt. "I dispute as too facile and possibly misleading the viewpoint which claims 'conversion was not to Christianity, but to Monachism - with its entire ascetic ideal'...Augustine had no abrupt interstices in his mind or milieu. So too after his conversion: the transition from asceticism to monasticism will again be gradual". See George Lawless, Augustine of Hippo and his Monastic Rule (Oxford: Clarendon press, 1987), 10-11.

${ }^{115}$ Brown 2000, 183-197; 330-339. Cf. Deane 1963, 173-174; Rist 1994, 208-236.

${ }^{116}$ See Conf. 3.4.7; 8.6.14; 8.7.16; 8.7.18; 8.10.22; 10.43.70. Lawless also notes that the stories of Antony in Vita Antonii by Athanasius, "libri Platonicorum", and Cicero's Hortensius are primary references for Augustine's initial monastic knowledge. See Lawless 1987, 9-11; 155-156.

${ }^{117}$ Nine legislative monastery treatises deriving from Augustine or his circle include: (1) Ordo Monasterii; (2) Praeceptum; (3) Praeceptum longius; (4) Regula recepta; (5) Obiurgatio; (6) Regularis informatio; (7) Epistula longior; (8) Ordo monasterii feminis datus; (9) Epistula longissima. (1) - (4) are for men whereas (5) - (9) are for women. See Lawless 1987, 65-69. On the basis of textual studies, Lawless believes that Praeceptum and Obiurgatio are genuinely Augustine's works, and Ordo Monasterii is possibly authentic as well, but overall, Lawless approves Henri Marrou's suggestion that these rules might not be wholly written by Augustine though they certainly come from his circle and are faithful to his monastic ideal. See Ibid., 125126; Cf. H. I. Marrou, Saint Augustine and his Influence through the Ages (New York, 1957), 155-156. I shall adopt this view in this section and consider these Rules as reflecting Augustine's monastic ideas.
} 
love of God should be united with the love of neighbours. ${ }^{118}$ On this basis, he specifies rigorous precepts to regulate the daily life of monks in terms of their activities and comportment, such as their praying, reading, working, bearings, and their appropriate attire. Moreover, Augustine also stipulates severe penalties (such as whippings) for punishing offences. ${ }^{119}$ The following paragraph on punishments in Praeceptum (Chapter 4) states Augustine's position:

If he neglects to mend his ways after such admonition, he should first be reported to the superior, before his behaviour is revealed to others whose task it is to expose his failing in the event of his denial... When convicted, he must submit to the salutary punishment determined by the judgement of the superior, or even that of the priest whose authority embraces such matters. If he refuses to submit to punishment even if he is determined not to leave, expel him from your society. ${ }^{120}$ [transl. Lawless]

The rules uphold the presbyter's authority and the practioners' obedience to stringent discipline. In comparison to the monasticism of Antony of Egypt and the austere Christian asceticism in the Syrian tradition, ${ }^{121}$ important differences are apparent.

Firstly, while Augustine does not abandon monastic asceticism, his objective is spirituality rather than physical mortification-abstinence is good as a supporting means but not as the main purpose. ${ }^{122} \mathrm{He}$ supports fasting as being beneficial for cultivating virtues and godliness if the physical condition of the servants of God permits it; ${ }^{123}$ fasting should be proportionate to one's health and that the aim of exterior abstinence is to make one's spirituality richer and more

\footnotetext{
${ }^{118}$ As Ordo Monasterii states at the beginning: "Love God above all else, dearest brothers, then your neighbour also, because these are precepts given us as primary principles". [transl. Lawless] Cf. Praeceptum: Primum propter quod in unum estis congregati, ut unanimes habitetis in domo et sit uobis anima una et cor unum in Deum.

${ }^{119}$ Ordo Monasterii: Si non emendauerit, sciat se subiacere disciplinae monasterii sicut oportet. Si autem talis fuerit aetas ipsius, etiam uapulet. Cf. Praeceptum, ch. 4.

${ }^{120}$ Praeceptum 4.9: Sed antequam aliis demonstretur, per quas conuincenda est, si negauerit, prius praeposito debet ostendi... Conuicta uero secundum praepositi, uel etiam presbyteri ad cuius dispensationem pertinet arbitrium, debet emendatoriam sustinere uindictam. Quam si ferre recusauerit, etiam si ipsa non abscesserit, de uestra societate proiciatur.

${ }^{121}$ Lawless 2000, 143.

${ }^{122}$ For Augustine's thoughts on asceticism and monasticism, see John Peter Kenney, "Mystic and Monk: Augustine and the Spiritual Life", in A Companion to Augustine, ed. Mark Vessey (Malden: Wiley-Blackwell, 2012), 284-295.

${ }^{123}$ Praeceptum 3.5: Carnem uestram domate ieiuniis et abstinentia escae et potus, quantum ualetudo permittit. Quando autem aliquis non potest ieiunare, non tamen extra horam prandii aliquid alimentorum sumat, nisi cum aegrotat.
} 
powerful. ${ }^{124}$ This inner spiritual asceticism is an innovation in comparison to the Egyptian and Syrian monastic traditions.

Secondly, Augustine considers asceticism to be for the goodness and freedom of people. The seed of asceticism is sown by grace and thus all the precepts are based on the law of love. Augustine emphasises this point at the end of Praeceptum: "The Lord grant you the grace to observe these precepts with love as lovers of spiritual beauty, exuding the fragrance of Christ in the goodness of your lives; you are no longer slaves under the law, but a people living in freedom under grace". ${ }^{125}$ Thus, one's gratitude for the Lord will naturally transform into caritas, the love of God and neighbours (Ordo Monasterii: diligatur Deus, deinde et proximus). In this love, the monastery shares possessions and lives harmoniously with one heart and soul to worship God. ${ }^{126}$ The notions of brotherly friendship and the father-son relationship expressed by Augustine are distinguished from the authoritative hierarchy in Egyptian monasticism (for example, the absolute authority of the "abba/amma" or "master-slave" mode). ${ }^{127}$

Thirdly, Augustinian monastery is not strictly isolated from the secular world, as his form of monastery is distinguished by its return to the spiritual renewal of emotions. In fact, Augustine's monastic paradigm does not permit a complete disregard of either one's fellow humans or the outside world. ${ }^{128}$ Peter Brown describes this as follows: "this monastery was unlike the ascetic communities isolated in the Egyptian desert: books were read, study was pursued,

\footnotetext{
${ }^{124}$ Praeceptum 3.5: Nec ibi eos teneat uoluptas iam uegetos, quo necessitas leuarat infirmos. Illi se extiment ditiores, qui in sustinenda parcitate fuerint fortiores; melius est enim minus egere, quam plus habere.

${ }^{125}$ Praeceptum 8.1: Donet dominus, ut obseruetis haec omnia cum dilectione, tamquam spiritalis pulchritudinis amatores et bono Christi odore de bona conuersatione flagrantes, non sicut serui sub lege, sed sicut liberi sub gratia constituti.

${ }^{126}$ Praeceptum 1.2: Primum, propter quod in unum estis congregati, ut unianimes habitetis in domo et sit uobis anima una et cor unum in Deum.

${ }^{127}$ Adolar Zumkeller compares Augustine's notion of monastic superiors with that in the Egyptian and Eastern monasteries, emphasising that the Augustinian monastery is based on a "father-son" relation rather than a "master-slave" relation. "Augustine vividly described the father-and-son relationship between superiors and their subjects. In this, he transformed the automatic obedience to any command demanded by Eastern monasteries into a more human and personal intercourse between superiors and subordinates... Basil himself, to illustrate monastic obedience, uses, not the father-and-son image, but the image of a master and his slaves". Zumkeller, Augustine's Ideal of the Religious Life (New York: Fordham University Press, 1986), 161-162. Also see Xia Dongqi 2007, 295-296.

${ }^{128}$ Conf. 10.43.70 demonstrates that Augustine was for some time motivated to be a hermit like Anthony: "Terrified by my sins and the pile of my misery, I had racked my heart and had meditated taking flight to live in solitude".
} 
learned conversation took place in a pleasant garden, in a town whose port brought many travellers. By the end of Augustine's life, visitors had become so many, that a hostel was built to lodge them". ${ }^{129}$ Thus, Augustine does not conceive of monastic members as holy people without worldly cares or charitable emotions.

To Augustine, a monastery is a micro-association that is stricter than the church and is closer to the essence of the true ecclesia, reflecting the ideal of the City of God in the earthly world. But a monastery is nevertheless a corpus permixtum, which pertains not only to the sphere of administration, but also to the spiritual level. Many monks and nuns maintain high virtues of godly emotions and distance themselves from secular desires and powers, even if they sometimes might be passively disturbed by outside affairs, whereas some members of monastic communities are inspired by the temptations and passions pertaining to worldly benefits instead of inner spiritual pursuits. But the main objective of monastic society is to attain the spiritual purification of emotions as well as to achieve moral improvement. This is different from the secular communities of unbelievers, as the monastic society shares the love of God, whereas the secular community is motivated by various reasons to adhere to earthly desires. ${ }^{130}$ Therefore, from the perspective of the spiritual scale of love and the virtues of renewed emotions, the monastery is higher than the church and both of them are gifts of divine grace that rank higher than the secular communities.

In the relations between monastery and church, the Donatists threated to create a schism in Catholic unity. Augustine was involved in the polemic with the Donatists after he began his presbyterate in 391, and he passionately wrote a series of treatises opposing them in the following decades. ${ }^{131}$ The Donatists spread widely throughout North Africa, especially in the ecclesiastical region of Numidia.

\footnotetext{
${ }^{129}$ Brown 2000, 195. Cf. Serm. 356.10.

${ }^{130}$ Kenney 2012, 295.

131 Augustine's anti-Donatist works are usually divided into two stages by the year 411 (the outbreak of the Pelagian controversy). The first stage works (395-411) include Psalmus contra partem Donati (393/394), Contra epistulam Parmeniani (400), De baptismo (400/401), Contra litteras Petiliani (402), Epistula ad Catholicos (=De unitate ecclesiae, ca.402), Contra cresconium grammaticum (406/409), De unico baptismo (410), and Breuiculus collationis cum Donatistis (411), among others. The works of the second stage (411-430) include De correctione Donatistarum (417), De patientia (418), Contra Gaudentium (419), and De haeresibus (428). See Karfíková 2012, 135-136.
} 
They were under the leadership of eminent bishops, such as Donatus, Parmenian, Primian and Petilian as well as the weighty defenders Gaudentius and Tyconius, whom Augustine listed as his polemic opponents. ${ }^{132}$ The Donatists considered the Catholic Church to be a contaminated society and they advocated purity, rebaptism, and martyrdom in their fanatical attacks against the Catholic Christians. ${ }^{133}$ To Augustine, these opponents constituted a heresy more than a schism. In correcting Cresconius's definition of Donatism as a schism, Augustine noted that the Donatists were not simply a separated group, but rather represented a doctrinal deviation of the heretics. ${ }^{134}$ Augustine defends his position by basing his argument on the following observations:

(1) Baptism is conferred by Christ, with the priests serving only as instruments for Him in forgiving sins, whereas the Donatist rebaptism attributes the merits of Christ to the minister and erroneously makes the latter a benefactor. ${ }^{135}$ In De baptismo, Augustine stresses that the sacrament of baptism is eternally valid, regardless of whether or not the ordained clergy is pure. Christ is the only mediator between the baptised and God in the "sacrament of grace" or "the grace of baptism" (sacramentum gratiae, gratia baptismatis) which is holy even when it takes place through a murderer's hands. ${ }^{136}$ Moreover, the Donatists accept the Catholic belief in the doctrine of the Trinity, ${ }^{137}$ so that the Catholic sacrament of baptism should not be repeated. In this sense, Augustine argues that rebaptism forms an essential doctrinal deviation and he refers to the Donatists as heretics.

(2) The church is the body of Christ and no one is sinless except through

\footnotetext{
${ }^{132}$ See Rev. J. R. King, "Introductory Essay" and "Preface", in Nicene \& Post-Nicene Fathers IV (New York, 1887; Reprint by Grand Rapids, MI: Eerdmans, 1996), 372-374; 405-406.

${ }^{133}$ Ibid., 405.

${ }^{134}$ Lenka Karfíková maintains that Augustine's attitude toward the Donatists undergoes a process. "Augustine refers to the Donatists as schismatics at first, and later as heretics, perceiving a gradual transition between the two". See Karfíková 2012, 137 and n. 26.

${ }^{135}$ See bapt. 5.19.25-5.27.38.

136 bapt. 5.21.29: Quapropter sacramentum gratiae dat Deus etiam per malos, ipsam uero gratiam non nisi per se ipsum uel per sanctos suos... Baptismum uero, quod est sacramentum remissionis peccatorum, quia nulli dubium est habere posse etiam homicidas. Cf. bapt. 4.14.22; 4.13.20-21; 1.1.1-2. Karfíková notes that there is a distinction between the validity of baptism and the "sacrament of grace" in Augustine, since the latter (also known as "the grace of baptism") refers to the spiritual sense of salvation rather than to the act of baptism itself. See Karfíková 2012, 139 and n. 37.

${ }^{137}$ correct. 1.1.1.
} 
the Lord who grants saving grace. However, the Donatists apply this pureness and holiness to a specific group, claiming that the Catholic Church is polluted. By contrast, Augustine insists that just as tares and wheat, or gold and wood, both good and evil members exist in the earthly church, intermixed until the end of the world when they will be differentiated by the Lord. They should not be separated now by a schism. ${ }^{138}$ Augustine emphasises that Christ is the head of the church, sending out the Holy Spirit as a consequence of the remission of sins. However, this does not mean that the baptised members of the visible church necessarily belong to the "Dove" (columba) of Christ (una est columba mea, una est matri suae), ${ }^{139}$ as he argues that the remission of sins does not occur during outward baptism, but in the true conversion of the heart. ${ }^{140}$ Augustine therefore argues that the true church cannot be divided into many schismatic parts (bapt.1.11.15: nec possunt ecclesiae tot esse quot schismata). The schismatics' separation of themselves from the perfection and unity of the dove fights against Christ Himself and Augustine states they will "depart into everlasting fire, prepared for the devil and his angels". ${ }^{141}$

(3) Martyrdom is encouraged as the great fruit of grace that imitates the sacrifice of Christ for true faith in charity, ${ }^{142}$ but the Donatist "martyrs" (such as the Circumcelliones) in their tearing of the body of Christ and assaulting Catholic Christians are fanatical persecutors rather than those who endure persecution themselves. ${ }^{143}$ Furthermore, the death of martyrs should defend the holy belief in the unity of Christ's body, shedding blood for caritas rather than for fame.

\footnotetext{
138 bapt. 4.12.19.

139 bapt.1.11.15: Ergo est illic Spiritus Sanctus; quia cum insufflante Domino datus esset discipulis... Una est enim, quaecumque illa sit de qua dictum est: Una est columba mea, una est matri suae, nec possunt ecclesiae tot esse quot schismata. The concept of the dove (columba) is related to the appearance of a dove when Jesus was baptised by the Holy Spirit through the hands of John. Here it refers to the true kingdom of Christ and the grace of salvation rather than the earthly physical church. The meaning of "dove" is discussed in Karfíková 2012, 141 (n. 50).

140 bapt. 6.32.62: ...et non esse consequens, ut quisquis habet Baptismum Christi etiam de peccatorum remissione securus sit; si hoc in Sacramento tantum habet nec ueraci cordis confessione conuersus est, ut dimittenti dimitteretur.

${ }^{141}$ See bapt. 4.13.21. "That they have no part given them in the saving grace of the Church, who, scattering and fighting against the Church of Christ, are called adversaries by Christ Himself...the Lord will then say, 'Depart from me, ye that work iniquity,' and 'Depart into everlasting fire, prepared for the devil and his angels"'. [transl. Rev. J. R. King]

142 bapt. 2.1.2.

${ }^{143}$ See Carole Straw, "Martyrdom", in Augustine through the Ages: An Encyclopedia, ed. Allan D. Fitzgerald (Michigan/Cambridge: Eerdmans, 1999), 539.
} 
Otherwise, suffering will become senseless and may even become an instrument of the Devil. ${ }^{144}$ The well-marked virtues of true martyrs are therefore charity, humility, and patience. Moreover, while true martyrs follow the sufferings of Christ to promote harmony in the church and peace of the world, the Donatists prefer reputation to any inner progress, and instead of defending virtues, they support the vanity of an "elite" group for honour. Thus, the Donatists do not represent true martyrdom. ${ }^{145}$

Through making these arguments against Donatism, Augustine attempts to combine the pureness, holiness, and perfection of the love of Christ with the mixed nature of the earthly monasteries and churches. It is clear that Augustine focuses most on ordinate love with virtues of renewed emotions, ranking the sufferings of Christ as the perfect model and Christian virtues as having various degrees dependent on a person's inner spiritual realm rather than outward honours. This is illustrated by the alignment that Augustine advocates. Firstly, the passions of true martyrdom exhibit great love, but they are inferior to the passions of Christ who grants redemption through the sufferings endured in crucifixion. ${ }^{146}$ Secondly, monks and nuns, being inferior to Christ and martyrs, are free to a considerable degree from secular passions, but harbour fervent godly emotions toward God and their fellow human beings. Thirdly, the pious laity develops renewed Christian passions that are better than the attitudes of secular unbelievers. Augustine reiterates at the end of the Rule that all the spiritual virtues of emotions are therefore cultivated by grace and they are not the merits achieved by people: "When you find yourselves doing what has been written here, thank the Lord, the giver of all good gifts". ${ }^{147}$

\footnotetext{
${ }^{144} E p .173$ : "But notice what follows: 'If I have not charity it profiteth me nothing.' You are called to that charity; you will not be allowed to perish away from that charity, and you think it profits you something if you hurl yourself to destruction, whereas it would profit you nothing if another put you to death as an enemy of charity. Even if you were burned alive for the name of Christ, you would suffer the punishment of eternal torment if you persisted in remaining outside the Church, separated from the edifice of unity and the bond of charity". [transl. Wilfrid Parsons]

${ }^{145}$ Straw 1999, 538.

${ }^{146}$ The passions of martyrdom do not function to remit sins, whereas Christ suffers to redeem humanity, which means that martyrs are "far inferior to Him" (Io. eu. tr. 84.2) See Straw 1999, 541.

147 Praeceptum 8.2: Et ubi uos inueneritis ea quae scripta sunt facientes, agite gratias domino bonorum omnium largitori.
} 
Spiritual sublimation: consecrated emotions in the temptations of the world

Political and ecclesiastical authorities represent different dimensions in social life. Political authorities are responsible for the secular political order and ecclesiastical authorities for the spiritual domain, but they are not isolated from each other. ${ }^{148}$ For example, emperors are crowned in church to guarantee the political legitimacy and many officials seek the aid of bishops to attain prestige in politics; likewise, some clergymen are more interested in civil affairs for their worldly interests. ${ }^{149}$ Two values, cupiditas and caritas, are mingled with each other in the secular world. Due to this corpus permixtum nature of the humanity, the church (as a symbol of the City of God on the earth) and the secular state display a hybridity with both good and bad acts, but Augustine stresses that they share no essence. ${ }^{150}$ The distinct missions combined with moral opacity in the two cities contribute to a complex relationship between the church and the state. I shall next survey Augustine's view of the moral status of emotions in the church-state relations.

Firstly, Augustine asserts that libido dominandi and caritas are both found in church and state, and these two emotions can be converted into each other. While authority and obedience are employed in the ecclesia, and a presbyter has the power to supervise the implementation of precepts, serving members in love, it is still possible for a presbyter to exercise libido dominandi over them. Indeed, Augustine warns that a high position among the Christians is more perilous than a low one. ${ }^{151}$ Likewise, secular political authorities can exert an abuse of power or benevolent rule in varying degrees, but if they accept the ecclesiastical values of caritas, despotic rule is not possible.

Secondly, the church and the state could make use of each other for the purpose of caritas. For instance, Augustine (after ca. 400) was inclined to accept coercion through use of political powers to force the Donatists into the Catholic unity, and he argues that this is consistent with humanity and love. ${ }^{152}$ Meanwhile,

\footnotetext{
${ }^{148}$ Herbert Deane uses the Pauline conception of "two swords" to describe the separate but cooperating tasks of the church and the state. See Deane 1963, 172-173.

${ }^{149}$ Deane 1963, 173.

${ }^{150}$ CD 14.28 .

151 Praeceptum 7.4: Quia inter uos, quanto in loco superiore, tanto in periculo maiore uersatur.

${ }^{152}$ Augustine's attitude to Donatism shows some changes. Before 400, he was hoping to persuade the Donatists through moderate dialogues (see $E p .23$ ), whereas after, especially with the issue of
} 
the Roman Empire used the episcopal judicial mediation (episcopale iudicium/episcopalis audientia) to improve their corrupted judiciary and civil administration. ${ }^{153}$ Augustine reminds us that the church and the state can also restrain each other. The ecclesia provides moral norms for the state and even emperors are required to observe these moral rules. It is thus possible for a bishop to reinforce his spiritual authority for politics, but his secular power is often restrained by the state. ${ }^{154}$ As a consequence, both political and ecclesiastical authorities are limited, both intermingled with two loves, cupiditas and caritas.

However, the essence of the ecclesia and that of the state are radically different. On behalf of the City of God, the church provides the spirit of caritas, whereas the temporal earthly politics often reflect the libido dominandi which represent values that are opposite. At this point, Augustine evaluates these two loves and morals of emotions on the spiritual level. His concept of the Dove (columba) of Christ places more emphasis upon the spiritual dimension of unity than on the integration of organisations. How can the members of this Dove settle worldly confusions and turbulences (caligo et tumultus saecularium actionum)? ${ }^{155}$ Augustine argues that in this suffering world, passions are burned with temptations and fears. Even if someone experiences the temporal joy of profit, they will be tormented in their deceptive happiness by losses and worries. ${ }^{156}$ Moreover, worldly affairs often present great burdens and troubles. Augustine comments on his reluctance to deal with the authorities:

People often ask about me, 'Why does he go to the authorities? What does a bishop want with the authorities?' But you all know that it's your needs that force me to go there, even though I don't want to...I have to put up with the humiliation, make my request, sometimes succeed, sometimes leave disappointed. Who would put up with all that if he

Edictum de unitate in 405 , he advocates coercion in the matter of schisms. For his changing attitudes on Donatism, see Xia Dongqi 2007, 319; Karfíková 2012, 145; Deane 1963, 185-208.

${ }^{153}$ The Emperor Constantine issued an edict in 318 to support episcopal courts (episcopalis audientia) in reconciling and judging the ecclesiastic and civilian disputes. See Xia Dongqi 2007, 300-301.

${ }^{154}$ Xia mentions the limitation of episcopal authorities in social affairs. As distinct from Peter Brown and Brook Manville, Xia argues that the secular power of the ecclesia was weak and limited and encountering official infringement, the church could only fight back wtih spiritual punishments. See Xia Dongqi 2007, 304-305.

${ }^{155}$ Ep. 48.1: Nostras enim saepe sauciat et debilitat caligo et tumultus saecularium actionum.

156 Serm. 302.2: Experti sumus quam aerumnosa, quam querelosa; circumdata temptationibus, plena timoribus; ardens cupiditatibus, subdita casibus; in aduersis dolens, in prosperis tremens; lucris exsultans, damnis excrucians... uera infelicitas, mendosa felicitas. 
weren't forced to?...I don't choose to have dealings with the authorities. ${ }^{157}$ [transl. Atkins] Instead of seeking wealth and excitements, due to the spirit of charity, Augustine is compelled to confront these trivial matters. He appears to be neither highly fervent, nor indifferent to secular matters, but chooses somewhere in between, "turning neither to the right nor to the left", remaining tranquil in his heart after having withdrawn from worldly interests. ${ }^{158}$ However, these matters are of no great importance to him. He maintains further that whether one strives passionately or suffers in charity, or takes the middle way, it should all be for "the glory of God":

This is the direction of the right road, 'which has its eyes ever towards the Lord, for He shall pluck [your] feet from the snare.' This course of life is not parched by activity, nor cooled by sloth, nor stormy, nor withered, nor bold, nor timid, nor headlong, nor fainthearted. 'These things do ye, and the God of peace will be with you.' ${ }^{159}$ [transl. Parsons]

This conviction is echoed in his late writings. In $C D$ 19.19, he states that it does not matter which of these lifestyles one chooses, such as leisure, action, or a combination of both. They are all praiseworthy provided that one follows charity according to God's will. The secular power and honour could be used righteously and beneficially for the wellbeing of the poor, following caritas rather than the libido. Thus, Augustine responds to those who passionately participate in secular affairs but disregard the meditation of God:

It is the love of truth which seeks a holy leisure, while it is under the impetus of love that we should undertake righteous business. If this latter burden is not imposed on us, we should devote our freedom to the search for and contemplation of truth. But if it is imposed on us, it is to be undertaken because of the impetus of love; and even then the delight in the pursuit of truth should not be entirely forsaken. For if these pleasures were to be taken away from us, our burden might prove too great for us. ${ }^{160}$

Augustine turns from sensual behaviour (or lifestyle) to the spiritual dimension, emphasising the scale of virtues of renewed life free from secular

\footnotetext{
157 Serm. 302.17: Saepe de nobis dicitur: quare it ad illam potestatem? Et quid quaerit episcopus cum illa potestate? Et tamen omnes nostis quia uestrae necessitates nos cogunt uenire quo nolumus...ferre humilitates, rogare, aliquando impetrare, aliquando tristes abscedere. quis uellet haec pati, nisi cogeremur?...nolumus habere rationem cum potestatibus.

${ }^{158}$ Ep. 48: Sicut autem inter ignem et aquam tenenda est uia, ut nec exuratur homo nec demergatur...non declinantes neque ad dexteram neque ad sinistram ...dilectissimi, diligite otium, ut uos ab omni terrena delectatione refrenetis.

${ }^{159}$ Ep. 48: Ipsa est enim actio recti itineris, quae oculos semper habet ad dominum, quoniam ipse euellet de laqueo pedes. Talis actio nec frigitur negotio nec frigida est otio nec turbulenta nec marcida est nec audax nec fugax nec praeceps nec iacens. Haec agite et Deus pacis erit uobis cum. ${ }^{160}$ CD 19.19.
} 
passions. Following the perfect passions of Christ, the true members of the Dove of Christ-martyrs, monks and nuns, the clergies, and the laity-represent new values in the world of desires. Through various gifts of grace, an ascent of love is cultivated toward perfection through inner spiritual improvement. Inward gracebased dispositions and virtues will build harmonious communities and societies that are characterized by the spirit of peace and charity toward neighbours. This is an ideal picture, but it is based on the assumption that even the pilgrimaging city of God is only moving toward perfection and that its members are not yet free from sinful inclinations. Augustine rebukes those who are lenient to damnable sins and he advocates harsh punishments on the wicked, even permitting offensive wars in some situations. His view of just war has been subject to many controversies. I shall next address this question.

\subsection{Libido dominandi, Just War and Earthly Peace}

In expressing his negative attitude toward war, Augustine believed that removing the disguise of military glory from the act of conquest leaves only the naked "lust for domination" (libido ista dominandi) and this lures the human race into inflicting great terror and suffering. ${ }^{161}$ In war, "all were wounded together: the smitten in body and the smiters in soul". ${ }^{162}$ Furthermore, the lust for domination drives the earthly city to enslave other nations and offer false glories. ${ }^{163}$ In brief, wars are always an evil that should be either avoided or prevented. ${ }^{164}$ Some scholars consequently presume that Augustine is a pacifist and that he maintains the tradition of early church pacifism. Others, however, notice that in specific situations, Augustine permits the application of violence and active attacks, and his support of the Christian wars against "unjust" nations implies an acceptance of violence rather than pacifism. Let us now review the competing interpretations.

\footnotetext{
${ }^{161}$ CD 3.14: Quid mihi obtenditur nomen laudis nomen que uictoriae? Remotis obstaculis insanae opinionis facinora nuda cernantur, nuda pensentur, nuda iudicentur...Libido ista dominandi magnis malis agitat et conterit humanum genus.

162 CD 3.22: mutuis dicam omnino uulneribus, cum percussus in corpore et percussor in animo feriretur!

${ }^{163}$ As Augustine notes in Praefatio of CD: Unde etiam de terrena ciuitate, quae cum dominari adpetit, etsi populi seruiant, ipsa ei dominandi libido dominator...

${ }^{164} C D$ 19.7: "Let everyone, therefore, who reflects with pain upon such great evils, upon such horror and cruelty, acknowledge that this is misery".
} 
David Lenihan contends that Augustine's thought is deeply rooted in the pacifist tradition of the earlier fathers and the spirit of the Gospel and should not be associated with the later theory of just war. ${ }^{165}$ Lenihan maintains that those who believe that Augustine is the principal originator of the just war theory are misled by both forged manuscripts and misinterpretations of some decretalists. $\mathrm{He}$ follows F. H. Russell's argument that several spurious letters such as Gravi de pugna were falsely attributed to Augustine during the sixth century, which led to the misconception that the medieval just war theory was established by Augustine. ${ }^{166}$ By interpreting Augustine's ideas on war and peace in eight Augustinian sources, ${ }^{167}$ Lenihan concludes that Augustine is not a "just warrior", but rather a genuine pacifist. Lenihan also holds that Augustine's peaceful position was misinterpreted by some medieval theologians such as Aquinas who wrongly surmised that Augustine had justified the Christian service in war. ${ }^{168}$ According to Lenihan, Augustine rather adheres to the ideas of earlier fathers such as Origen and Tertullian, advocating a genuine love of peace, ${ }^{169}$ being "a personal pacifist who would have himself killed rather than exercise a legal right of selfdefense against a criminal". ${ }^{170}$ Lenihan offers evidence for his claim as follows: (1) As a criterion to evaluate the character of war, Augustine uses the inner order of society, referring to the attack of the Visigoths as injustice since it disrupts social order. This serves to illustrate that his concept of war differs from that of the just

\footnotetext{
165 "I attempt to show that the just war theory is not on a continuum from Augustine, whose thought is much more complex and that, on the contrary, Augustine is on a continuum with the pacifist tradition of the earlier fathers". David Lenihan, "Just war Theory in the Work of Saint Augustine", in Augustinian Studies 19 (1988), 37.

166 Lenihan 1988, 37-38.

167 These works include: (1) De libero arbitrio 1.5; (2) Contra Faustum Manichaeum 22; (3) Ep. 138, to Marcellinus; (4) Ep. 189, to Boniface; (5) Ep. 222, to Darius; (6) Quaestiones in Heptateuchum 6.10; (7) De sermone Domini in monte 30; (8) De civitate Dei. Ibid., 42.

168 "It would seem that Augustine has been cast into this position by theologians who, like Thomas Aquinas, answered the moral question of whether it was always sinful for Christians to engage in warfare by ferreting, out of context, small proof texts from Augustine to justify Christian participation in warfare". Ibid., 38.

169 “Augustine, in my estimation, is not a 'just warrior' and the medieval just war is not a direct descendent, but a mis-interpretation and simplification by the decretalists who failed to see the full Augustinian position with its spiritual complexity. In his interiority, deep spirituality, and genuine love of peace, Augustine is in continuity with the earlier fathers and the spirit of the Gospel". Ibid., 41. For Augustine's adherence to predecessors such as Origen and Tertullian and his discontinuity with Aquinas on the issue of just war, see Lenihan 1988, 40-46; 55-56.

${ }^{170}$ Lenihan 1988, 41.
} 
war theories. ${ }^{171}$ (2) Augustine distinguishes the concept of the justice of God from the justice of the law, arguing that wars may be just in terms of human laws but do not represent "true justice" according to God. His dichotomy of "justice" differs from the account by Aquinas of "natural justice". ${ }^{172}$ (3) Augustine does not form a unified theory of "just war", but discusses it in a disorganised way. In effect, minor inconsistencies in his formulations should not be taken to affect his pacifist position. ${ }^{173}$ (4) War is evil and inevitable, but it is needed in God's plan in the world. ${ }^{174}$ (5) Augustine never advocates militarism, but always underscores peace and love. ${ }^{175}$ (6) Augustine does not forbid Christians from taking up arms, but he states emphatically that those who participate on the battlefield should harbour love in their hearts. ${ }^{176}$ Through these points, Lenihan concludes that Augustine is "a saint of peace and love", as he bases the concept of the justice of war on the spirit of God, and Augustine's reluctant permission to use military means is related to his considerations concerning God's plan. ${ }^{177}$

In line with Lenihan, Robert Holmes argues for Augustine's personal pacifist position and his ties to earlier fathers, but Holmes adds that Augustine regarded war as a necessary part of historical reality and often justified it from the Christian perspective. ${ }^{178}$ Holmes suggests that when examining Augustine's position, it is important to take into account the concepts of motive and intention, because the moral character of outward acts is determined by the interiority,

\footnotetext{
${ }^{171}$ Lenihan maintains that Augustine did not consider the sackings by the Vandals and the Visigoths to be foreign wars in the modern sense, but rather civil wars within the Roman Empire. Therefore, the question of justice is based on whether or not the war maintains social order. Lenihan 1988, 53.

172 "'[For Aquinas], 'justice' is one and unchangeable, and always takes its origin from the naturally just...For Augustine, justice was a subjective question, dependent on motivation". This produces distinct notions of just war in Augustine and Aquinas. See Lenihan 1988, 54-55.

${ }^{173}$ Lenihan 1988, 55.

${ }^{174}$ Lenihan 1988, 56.

175 Lenihan 1988, 56.

${ }^{176}$ Lenihan 1988, 56.

${ }^{177}$ Lenihan 1988, 57.

178 "That Augustine was almost certainly a personal pacifist may be granted...it is arguable true that Augustine stands on a continuum in many respects with earlier Christian writers...Moreover, as I shall suggest, nothing in the preceding precludes the possibility that Augustine has carved out a position that distinguishes him from both the pacifists of the early church and the just war theories of the later church". Robert Holmes, "St. Augustine and the Just War Theory", in The Augustinian Tradition, ed. Gareth Matthews (Berkeley and Los Angeles: University of California Press, 1999), 324 and 330.
} 
intentions and motives. ${ }^{179}$ According to Augustine, in comparison to the true justice of God, a temporal order can be somewhat just, in other words, not completely just, or entirely unjust. The right intention in waging war is to aim for true justice and peace. ${ }^{180}$ As for motives, Augustine values the role of love in maintaining order. When God commands people to wage a war, it is clearly just. However, even without this divine command, good motivations combined with the right intentions makes a war similarly justified. Nonetheless, Christians can also accept military action that fulfils the temporal criteria of justice without its leaders having good motivations, because "good deeds" can be done intentionally with either good or evil motives, the inner motive being morally decisive. ${ }^{181}$ The ultimate motivation is difficult to determine and this presents a problem in Augustine's discussion on the justification of war. For this reason, Augustine tends to accept wars that show temporal justice, but this remains an abstract principle for Augustine in comparison to later theories of just wars. As for the Christians' participation in war, the fundamental imperative is to obey the state and avoid evils such as cruelty, love of violence, or a lust for power. ${ }^{182}$ Holmes concludes that Augustine's position is partially in line with the later just war theory that foregrounds the unification of pacifism and an acceptance of just war. He maintains that Augustine "should have been [a personal pacifist] and, to be consistent, should have been a universal pacifist as well”. ${ }^{183}$

Herbert Deane suggests a contrary position: "Augustine follows Athanasius and Ambrose in rejecting the pacifism and antimilitarism of many of the Church Fathers, such as Tertullian, Origen, and Lactantius". ${ }^{184}$ Deane refers to two instances when Augustine regards an offensive war as a just war. One instance occurs when a country does not make restitution for wrong actions committed by its citizens; the other occurs when a country does not return

\footnotetext{
179 In discussing Augustine's view of the relation between motivation, intention, and action, Holmes states that "both motives and intentions can determine the moral character of acts...But motives are basic, because they determine the character of intentions as well as of acts". Holmes 1999, 326.

180 "Peace, for Augustine, entails order, and a given temporal order can be just or unjust (at least, can vary in degrees of injustice, since, strictly, no temporal order can be completely just). One ought only to aim for a just peace". Ibid., 332.

${ }^{181}$ Ibid., 326-327.

182 Ibid., 333-336.

183 Ibid., 337.

${ }^{184}$ Deane 1963, 155.
} 
misappropriated properties. ${ }^{185}$ Moreover, Deane refers to Augustine's defence of violent acts by the prophet Moses in a way that differs from Faustus' pacifism:

Against the doctrinaire pacifism of the Manicheans, he [Augustine] argues that when God commanded Moses to carry on wars, He [Moses] "acted not in cruelty, but in righteous retribution, giving to all what they deserved, and warning those who needed warning". The pacifist who regards death as the great evil involved in war is ready to buy life at the price of subjection to injustice...If he [the monarch] decides that war is necessary, he has the right to begin hostilities, and the soldiers and citizens under his command must obey his orders, whether or not they agree with his judgment. ${ }^{186}$

Deane does not believe Augustine to be a pacifist who will sacrifice justice to save lives in wars, since anarchy and injustice are the worst evils in Augustine and he accepts violent means necessary to correct wrongs, including wars. ${ }^{187}$ Augustine's approval of fighting, Deane adds, is in accordance with the commandments of Christ who never advocated absolute pacifism or tolerance of wrongdoings. ${ }^{188}$ It is thus clear that Augustine deviated from the earlier church fathers' tendency to be opposed to any Christian military service. ${ }^{189}$

The above interpretations agree on Augustine's understanding that the moral evils of warriors are associated with detestable passions such as "the desire for violence, cruelty of revenge, fierce and implacable enmity, furious rebelliousness, and the lust for power". ${ }^{190}$ They also note that Augustine teaches us how to eliminate these desires and restore earthly peace and order. However, they hold contrary positions regarding Augustine as a pacifist. I shall suggest that neither pacifism nor militarism best describes his thinking on war. The commandments of God form the core of his theory of just war and they should transform the evil driving passions of war into a sublimated spiritual state through the participants' obedience. Let us turn to some of his writings, such as Contra

\footnotetext{
185 Quaestiones in Heptateuchum 6.10: "If some nation or some state which is warred upon has failed either to make reparation for an injurious action committed by its citizens or to return what has been wrongfully appropriated". [transl. Deane] See Deane 1963, 160 and 312 (n. 24).

${ }^{186}$ Deane 1963, 161-162.

187 Deane 1963, 161-162.

${ }^{188}$ Deane 1963, 164.

189 See Deane 1963, 155 and 309 (n. 4).

${ }^{190}$ c. Faust. 22.75: Nocendi cupiditas, ulciscendi crudelitas, inpacatus atque inplacabilis animus, feritas rebellandi, libido dominandi et si qua similia. For English texts of Contra Faustum Manichaeum, I adopt Stothert's translation with modifications (Nicene and Post-Nicene Fathers $I V)$ in this chapter.
} 
Faustum Manichaeum 22, Quaestiones in Heptateuchum 6.10, Epistulae 93, and De civitate Dei, to examine how faith factors into his notion of war.

\section{The Command of God as a justification for war}

Augustine emphasises the decisive role of divine command in justifying wars and he thus distinguishes between the true and qualified human justice in the doctrines of jus ad bellum and jus in bello. ${ }^{191}$ From the perspective of jus ad bellum, just causes are the primary criteria for evaluating the justifiability of wars. In seeking just causes for undertaking a war, the command of God should rank the highest. Augustine regards the divine command as the sufficient and necessary condition for true justice, whereas other supporting just causes belong to qualified human justice that should comply with God's plan. As explained in Contra Faustum Manichaeum 22.75, Augustine stresses the authority of God as well as the control of human passions in a just war in accordance with divine command:

When war is undertaken in obedience to God to rebuke, or humble, or crush the pride of man, one should not doubt that it is undertaken in a righteous way; for even the wars which arise from human desire cannot harm the eternal God, not even hurt His saints; for in the trial of their patience, and the chastening of their spirit, and in bearing fatherly correction, they are rather benefited than injured. No one can have any power against them but what is given him from above. For there is no power but of God, who either orders or permits. ${ }^{192}$

It is unjust to be disobedient to God's command to wage offensive attacks. This may be motivated by people being captivated by earthly temptations, such as a desire for temporal happiness, and their excuses for sustaining order and peace are unjust in the sight of God. Augustine refuses to regard conniving evil endeavours as a valuable type of pacifism. Arguing against Faustus' criticism of the Israelites'

\footnotetext{
191 The doctrine of jus ad bellum is primarily concerned with just causes and conditions for undertaking wars while jus in bello concerns behaviour in war. There are different dimensions of evaluating the righteousness of war. For a detailed discussion on the distinction of jus ad bellum and jus in bello, see John Mark Mattox, Saint Augustine and the Theory of Just War (London· New York: Continuum, 2006), 45-60.

192 c. Faust. 22.75: Bellum autem, quod gerendum Deo auctore suscipitur, recte suscipi dubitare fas non est uel ad terrendam uel ad obterendam uel ad subiugandam mortalium superbiam, quando ne illud quidem, quod humana cupiditate geritur, non solum incorruptibili Deo, sed nec sanctis eius obesse aliquid potest; quibus potius ad exercendam patientiam et ad humiliandam animam ferendamque paternam disciplinam etiam prodesse inuenitur. Neque enim habet in eos quisquam ullam potestatem, nisi cui data fuerit desuper. Non est enim potestas nisi a Deo siue iubente siue sinente.
} 
invading the Egyptians, Augustine contends that it is rather a sin not to punish those who revolt against God:

In this Moses not only did not sin, but it would have been sin not to do it...The people at that time were still carnal, and engrossed with earthly affections; while the Egyptians were in open rebellion against God...Thus the Egyptians deserved the punishment, and the Israelites were suitably employed in inflicting it. ${ }^{193}$

This intolerant attitude concurs with Augustine's statement in $C D$ 1.9, where he rebukes those who love the temporal sweetness of refraining from fighting against the damnable sins of the wicked, claiming that the affliction of good men together with the wicked in this world is the right punishment by God:

Because they are lenient towards the damnable sins of the wicked, the good are justly scourged alongside them in this world...It is right that they should know bitterness in this life when they are afflicted by God in common with the wicked; for, because they loved the sweetness of this life, they neglected to be bitter to the wicked. ${ }^{194}$

It is clear that Augustine's consideration of whether to wage war is not based on a pacifist conviction, but on the principle of justice, especially as a decree of God. Augustine does not intend to sacrifice justice either to spare the wicked or to sustain an evil order, but rather suggests shedding blood to defend divine justice, which he considers to be true justice that is preferred above human causes.

From the standpoint of jus in bello, Augustine appreciates just behaviour, but does not object to military deceptions. He emphasises, however, that the application of deceptive tactics should be based on faith. For example, in the case of Joshua conducting an ambush to conquer the city of Ai under the command of God, Augustine notes, "Once an individual has undertaken this kind of war, it does not matter at all, as far as justice is concerned, whether he wins victory in open combat or through rushes". ${ }^{195}$ Violence and deceptive acts are accepted in a justified war, which serves to illustrate that his attention is concentrated on ends

\footnotetext{
193 c. Faust. 22.71: Quod faciendo Moyses usque adeo non peccauit, ut non faciendo peccaret...Carnalis itaque adhuc ille populus erat et rerum terrenarum cupiditate occupatus, Aegyptii uero sacrilegi et iniqui...Digni ergo erant et isti, quibus talia iuberentur, et illi, qui talia paterentur.

194 CD 1.9: Tamen, quia propterea peccatis eorum damnabilibus parcunt, dum eos in suis licet leuibus et uenialibus metuunt, iure cum eis temporaliter flagellantur...iure istam uitam, quando diuinitus adfliguntur cum eis, amaram sentiunt, cuius amando dulcedinem peccantibus eis amari esse noluerunt.

${ }^{195}$ Quaestiones in Heptateuchum 6.10, quoted in Mattox 2006, 64. Cf. Louis J. Swift, The Early Fathers on War and Military Service (Wilmington: Michael Glazier, Inc., 1983), 138.
} 
rather than means. This point is explained in Ep. 93.7-8, where he reminds us not to be misled by similar performances without paying attention to intentions:

Let us learn, brethren, when actions are alike, to distinguish the intentions of the actors; otherwise, if we shut our eyes to this, we might judge falsely, and we might accuse wellwishers of doing us harm...It is clear that the bad have always persecuted the good, and the good have persecuted the bad; the former to do harm unjustly, the latter to bring about amendment by punishment; the one unboundedly, the other within bounds; those as slaves of passion, these out of love. ${ }^{196}$ [transl. Parsons]

Among all the goals in war, the goal of God ranks highest because that objective constitutes absolute good even when it involves violence and punishment. This is fundamentally different from the pacifist position that avoids the evil of death and maintains the existing order at the cost of saving the wicked. According to Augustine, this pacifism is a greed for self-interest to avoid enmities or an infirm fear of revenge and injury, which are sins. ${ }^{197}$ These facets of jus ad bellum and jus in bello in Augustine are evidence that he is not a pacifist, as his standpoint is based on God's absolute authority and on the corresponding human obedience without lenience towards crimes. From this perspective, one might inquire whether the love of "turning the other cheek" and "not resisting evil" in Christ contradicts the law of fighting against evil.

\section{The unification of law and love and the renewed emotions in war}

It seems that the Christ Himself violates the Old Testament command of fighting against evil when by proposing the new commandment that "ye resist not evil: but if any one strike thee on the right cheek, turn to him the left also". ${ }^{198}$ Then Christ seems to break His own precept by resisting the provocation of being struck on

\footnotetext{
${ }^{196}$ Ep. 93.7-8: Discamus, fratres, in similitudine operum discernere animos operantium, ne clausis oculis calumniemur et beniuolos pro nocentibus accusemus...sed plane semper et mali persecuti sunt bonos et boni persecuti sunt malos, illi nocendo per iniustitiam, illi consulendo per disciplinam; illi immaniter, illi temperanter; illi seruientes cupiditati, illi caritati. On the last line, "slaves of cupidity" would be a translation more accurate than "slaves of passion".

197 CD 1.9: Plerumque enim ab eis docendis ac monendis, aliquando etiam obiurgandis et corripiendis male dissimulator...ne impediant et noceant in istis temporalibus rebus, siue quas adipisci adhuc adpetit nostra cupiditas, siue quas amittere formidat infirmitas...tamen, quia propterea peccatis eorum damnabilibus parcunt.

${ }^{198}$ Matthew 5:39. Cf. c. Faust. 22.76:...quia dominus postea Iesus Christus, "Ego, inquit, dico uobis non resistere aduersum malum; sed si quis te percusserit in maxillam tuam dexteram, praebe illi et sinistram”.
} 
the face when He was examined by the High Priest. ${ }^{199}$ The Manichaeans cited these two inconsistencies to suggest that the Gospel and the Law are mutually opposed and further that the utterance of Christ is opposed to Himself. ${ }^{200}$ They pose the question, "why one and the same God commanded the prophets in the old times to make war, and forbade the apostles?"201

Augustine responds to this accusation in Contra Faustum Manichaeum 22.76 by briefly stating that what Christ refers to in His new commandment is not outward actions, but rather the renewal of inward disposition. To Augustine, the virtues of this renewed heart are also consistent with the righteousness of the Father in the Old Testament. ${ }^{202}$ However, Augustine soon shifts to allege a deeper intrinsic consistency between the divine law and the gospel. He offers a broader theological interpretation of the real meaning of war and peace and accounts for why Christ delivered the new commandment to us. Augustine provides the following arguments:

Firstly, he points out that the Father's earthly promises and the decree to attack the ungodly nations in the Old Testament hide the secret of the Kingdom of Heaven which is disclosed by the Son in the gospel. Both the Old and the New Testament imply the same righteous Heavenly Kingdom, which is the opposite of all earthly kingdoms. ${ }^{203}$ The violent means of the divine command in the old times are unified with the virtues of patience and love in the gospel, as both of them resist injustice and impiety and reveal the truth of the City of God. Especially the new commandment clearly conveys the grace of patience and humility which

\footnotetext{
${ }^{199}$ Ep. 138.2.13: "Our Lord Jesus Himself, our perfect example of patience, when He was smitten on the face, answered: 'If I have spoken evil, bear witness of the evil, but if not, why smites thou me?' If we look only to the words, He did not in this obey His own precept, for He did not present the other side of his face to him who had smitten Him, but, on the contrary, prevented him who had done the wrong from adding thereto". See Deane 1963, 164-165.

${ }^{200}$ c. Faust. 22.77: Isti certe, si ista diuersa in testamentis singulis inuenirent, uetere et nouo, etiam hoc clamarent duo sibi testamenta esse contraria. Quid ergo nunc respondebunt, cum idem ipse dicit.

${ }^{201}$ c. Faust. 22.77: Cur non admittunt certi mysterii gratia eundem unum Deum tunc prophetas gerere bella iussisse, nunc apostolos prohibuisse?

${ }^{202}$ c. Faust. 22.76: Si autem propterea putant non potuisse Deum bellum gerendum iubere...intellegant hanc praeparationem non esse in corpore, sed in corde; ibi est enim sanctum cubile uirtutis, quae in illis quoque antiquis iustis nostris patribus habitauit.

${ }^{203}$ c. Faust. 22.76: Ubi autem uenit plenitudo temporis, ut nouum testamentum reuelaretur, quod figuris ueteris uelabatur, euidenti testificatione iam demonstrandum erat esse aliam uitam, pro qua debet haec uita contemni, et aliud regnum, pro quo oportet omnium terrenorum regnorum aduersitatem patientissime sustineri.
} 
reflect the spirit of fight and sacrifice for the sake of eternal felicity. This spirit echoes the prophecy in the Old Testament, as Augustine exemplifies the cases of martyrs and Saul:

The number of such witnesses [the sufferings and death of martyrs] is so great, that if it pleased Christ - who called Saul by a voice from haven, and having changed him from a wolf to a sheep, sent him into the midst of wolves - to unite them all in one army, and to give them success in battle, as He gave to the Hebrews, what nation could withstand them? What kingdom would remain unsubdued? ${ }^{204}$

The words and deeds of the Son of God obey the law, sending Himself and His followers as sheep into this world of fighting with wolves, but promising that nothing will be lost (not even a hair) in the Kingdom of Heaven. ${ }^{205}$ Therefore, according to the law of the gospel, the theme of fighting against ungodly enemies with patience and love for the coming of the eternal kingdom of peace is coherent.

Secondly, to Christians, the evils of war constitute sinful desires for pleasure and power, and fighting against these evil passions is not undertaken for temporal happiness, but for eternal peace hereafter. ${ }^{206}$ Furthermore, living in peaceful subjection is cowardly behaviour. This means that good men should undertake wars to punish wicked enemies without desire for violence (nocendi cupiditas) or lust for domination (libido dominandi), pursuing true justice and peace in obedience to lawful authorities and to Christ's commandment. ${ }^{207}$ In other words, the correct notion of war and peace should be based on Christ who provides an example for both soldiers and rulers alike, such as fighting against

\footnotetext{
${ }^{204}$ c. Faust. 22.76: Quorum numerus tantus effloruit, ut, si eos Christus, qui de caelo Saulum uocauit et ex lupo factum ouem in medio luporum misit, congregatos uellet armare atque adiunare pugnantes, sicut hebraeos patres adiuuit, quae gentes resisterent? Quae regna non cederent?

${ }^{205}$ c. Faust. 22.76: Itaque in plenitudine temporum Filius Dei factus ex muliere, factus sub lege, ut eos, qui sub lege erant, redimeret, factus ex semine Dauid secundum carnem mittit discipulos uelut oues in medio luporum et monet, ne timeant eos, qui corpus occidunt, animam autem non possunt occidere, promittit etiam ipsius corporis renouandam integritatem usque ad capilli reparationem.

${ }^{206}$ c. Faust. 22.76:...qua iam docendum erat non propter temporalem in hac uita, sed propter aeternam post hanc uitam felicitatem deo esse seruiendum, ea quae uulgo infelicitas dicitur pro illa felicitate subeunda fuerat et ferenda.

207 c. Faust. 22.74: Quid enim culpatur in bello?An quia moriuntur quandoque morituri, ut domentur in pace uicturi? Hoc reprehendere timidorum est, non religiosorum. Nocendi cupiditas, ulciscendi crudelitas, inpacatus atque inplacabilis animus, feritas rebellandi, libido dominandi et si qua similia, haec sunt, quae in bellis iure culpantur, quae plerumque ut etiam iure puniantur, aduersus uiolentiam resistentium siue Deo siue aliquo legitimo imperio iubente gerenda ipsa bella suscipiuntur a bonis. Cum in eo rerum humanarum ordine inueniuntur, ubi eos uel iubere tale aliquid uel in talibus oboedire iuste ordo ipse constringit.
} 
idolatry (the slaughter and evil passions in war being comparable to idolatry) $)^{208}$ and against earthly fallacious peace. From this viewpoint, soldiers will not be murderers avenging each other in battles, and emperors will gain great victories over ungodly nations. ${ }^{209}$

Thirdly, the new commandment established the renewal of inward disposition as well as the improvement of the morality of emotions. Against ungoverned passions in war, good emotions, such as mercy and benevolence, will be cultivated, even though outward punishments are still necessary. Augustine explains that the virtue of patience and turning the other cheek "may be in the inward disposition, though it is not exhibited in bodily action or in words", ${ }^{210}$ as in the case of a slapped apostle:

For when the apostle was struck, instead of turning his other side to the man, or telling him to repeat the blow, he prayed to God to pardon his assailant in the next world, but not to leave the injury unpunished at the time. Inwardly he preserved a kindly feeling, while outwardly he wished the man to be punished as an example. ${ }^{211}$

With this kindly affect of heart, one is not attached to earthly things, but seeks enjoyment in God with an elevated state of mind. ${ }^{212}$ Instead of being led by the wrong love and ungoverned passions to eternal punishment, a renewed inward disposition will receive a just reward, with this conversion made possible by the grace of God through Christ. ${ }^{213}$

\footnotetext{
${ }^{208}$ c. Faust. 22.92: "We must now inquire into the prophetic significance of the command, that many of those who, while Moses was absent, made an idol for themselves should be slain without regard to relationship. It is easy to see that the slaughter of these men represents the warfare against the evil principles which led the people into the same idolatry...And a similar command is given by the apostle, when he says, 'Mortify your members which are on earth; fornication, uncleanness, luxury, evil concupiscence, and covetousness, which is idolatry.'[Col. 3.5]"

${ }^{209}$ c. Faust. 22.76: De domino Christo-ipse est enim pax nostra...Christiani quoque imperatores plenam gerentes fiduciam pietatis in Christo de inimicis sacrilegis, qui spem suam in sacramentis idolorum daemonum que posuerant, gloriosissimam uictoriam perceperunt.

${ }^{210}$ c. Faust. 22.79: Posse esse in praeparatione cordis, etiamsi non exhibeatur gestu corporis et expressione uerborum.

${ }^{211}$ c. Faust. 22.79: Quandoquidem apostolus palma percussus potius deum rogauit, ut iniurioso homini in futuro saeculo parceretur, in praesenti autem illa iniuria non inulta relinqueretur, quam uel praebuit ferienti alteram partem aut ut iterum feriret admonuit. Tenebat certe interius dilectionis adfectum et exterius requirebat correctionis exemplum.

212 c. Faust. 22.78: Fit autem homo iustus, cum ob aliud non adpetit rebus uti, nisi propter quod diuinitus institutae sunt, ipso autem Deo frui propter ipsum se que et amico in ipso Deo propter eundem ipsum Deum.

213 c. Faust. 22.78:...et quia de hac iusta poena non liberat nisi misericors gratia, certum est... Quis me liberabit de corpore mortis huius? Gratia Dei per Iesum Christum dominum nostrum.
} 
What Augustine offers in the above writings is the unification of the divine law and the new commandment in the united spirit of fight and love. He examines the concept of war and peace in the context of the City of God, emphasising that the spiritual meaning of war is to fight against the lustful passion of seeking earthly powers in self-love, whereas true peace is enjoying God in the Kingdom of Heaven. On the basis of this theological interpretation, Augustine discerns inward dispositions and outward actions in war. He focuses on the question of how to free oneself from detestable passions and transform them into gracious and merciful emotions with the new spirituality of the heart, without losing one's readiness for just punishments in outward military actions. He maintains that the new commandment is coherent with the divine command of violence in the old times, but the latter is qualified by the idea of fighting against the wicked with the virtues of patience and love. ${ }^{214}$ This model defines the guidelines for Christian service in the military order. Augustine's position is obviously distinguished from pacifists who will tolerate evils to reserve the corrupted order and cowardly life.

From a practical standpoint, Augustine's emphasis on the divine command as the central law for identifying ungodly nations as evil objects might support offensive attacks using the authority of God to punish sacrilegious deeds and support aggressions such as crusades and militarism. ${ }^{215}$ Moreover, according to Augustine, Christian soldiers should obey the commands of a ruler even when he is violating the principle of justice to wage aggressive or suppressive wars. Due to their duty of obedience to political authority, soldiers are innocent and exempted from culpability. ${ }^{216}$ This means that Augustine does not allow room for them to protest the unjust commands of superiors in the military order. ${ }^{217}$ This is evidence that his position has moved away from the earlier fathers who advocated nonviolent pacifism.

\footnotetext{
${ }^{214}$ For a related discussion on the virtues of love in war, see Eric Gregory, Politics and the Order of Love (Chicago: The University of Chicago Press, 2008), 298-318.

${ }^{215}$ For the crusades and the influence of Augustine's theory of just war, see Jonathan Riley-Smith, The Crusades, Christianity, and Islam (New York: Columbia University Press, 2008), 1-44.

${ }^{216}$ c. Faust. 22.75: "it may be an unrighteous command on the part of the king, while the soldier is innocent, because his position makes obedience a duty". Cf. Rom. 13.

217 "Augustine leaves no room for disobedience based upon the citizen's or soldier's individual decision that the command he receives is unjust or illegitimate". See Deane 1963, 163. Cf. Holmes $1999,334$.
} 
Lenihan and Holmes detect some pacifist elements in Augustine's theory of just war, but the gracious inward feeling only directs one away from the wrong passions of war but not from the good intention of punishing evils. Thus, one cannot conclude that Augustine is a genuine pacifist in line with his predecessors' pacifism. Deane examines the formulations in which Augustine advocates participation in offensive wars and Augustine's intolerant attitude towards evil, which is distinguished from the pacifist proposition. Nonetheless, Deane does not attend to Augustine's evaluation of just war and peace from the transcendental perspective of the Kingdom of Heaven, which is hidden in the Old Testament, but disclosed by Christ in the gospel. In defending the belief of the City of God, Augustine is a proponent of fighting against the libido dominandi in the earthly city with patience for the sake of true peace and justice of the Kingdom of God, because Christ proclaims, "I came to send fire on the earth, and how I wish it were already kindled". 218

Having explored Augustine's notion of freedom from evil passions in social life from the perspective of the three levels of human society in this chapter, I shall direct my attention to the issue of redemption and the deification of humans and their emotions. I have presented evidence that Augustine adopts an inward ranking of consecrated emotions and regards the passions of Christ as the perfect model. By virtue of His grace and love, men could cultivate virtuous lifestyles to disengage from the bondage of evil desires gradually, progressing toward the consummation in their pilgrimaging life. It is now appropriate to explore the goal of freedom from passions and consider the significance of the passion of Christ in terms of salvation.

\footnotetext{
${ }^{218}$ Luke 12:49. Cf. c. Faust. 22.93: Hanc sacrilegam societatem Dominus Christus illo igne conburit, de quo in Euangelio dicit: Ignem ueni mittere in terram.
} 



\title{
CHAPTER FIVE: BECOMING GOD?-REDEMPTION THROUGH PASSION AND THE DEIFICATION OF EMOTIONS
}

\author{
Hoc est enim plenum gaudium nostrum quo amplius non est, frui Trinitate Deo ad cuius \\ imaginem facti sumus. (De Trin. 1.8.18) \\ Ibi uacantes uidebimus quoniam ipse est Deus; quod nobis nos ipsi esse uoluimus, \\ quando ab illo cecidimus, audientes a seductore: Eritis sicut dii, et recedentes a uero \\ Deo, quo faciente dii essemus eius participatione, non desertione. (CD 22.30)
}

Si filii Dei facti sumus, et dii facti sumus...diis gentium, daemoniis terribilis; diis a Se factis, filiis amabilis. (En. Ps. 49.2) $)^{1}$

The present chapter will further analyse Augustine's theoretical position on deifying emotions by exploring the reasons for Christ's taking on human passions and by inquiring whether the future Heavenly human citizens could become God (theosis) by participating in divinity. As we have witnessed in his theory of the two cities, Augustine argues that to exercise their own lustful dominion, some rational beings display disobedient pride as well as a desire to be God and in doing so, they have departed from God. ${ }^{2}$ Indeed, to Augustine, the hallmark of depraved psychology for both fallen angels and humans is their aspiration to be God and their attempt to imitate God's authority. Augustine attempts to explain how God provides therapy for the emotion of pride and how humans may become filled with amor Dei instead of amor sui.

In the first section (5.1), I shall evaluate the main lines of Augustine's psychological approach to the Trinity. Following his teaching on the human mind as the image of the Trinity, I shall address the relevance of his discussion on human passions to interpreting divine "emotions" in section two (5.2). In the third part (5.3), I shall survey Christ's passions during the crucifixion and determine the reason that the second person of the Trinity takes on human emotions. At the end state of the two cities, good and bad angels will exhibit different mental states, joy and suffering, and I shall discuss the nature of these in section four (5.4),

\footnotetext{
${ }^{1}$ The English translation of Augustine's Expositions of the Psalms comes from Boulding's edition. See The Works of Saint Augustine III, transl. Maria Boulding and ed. John E. Rotelle (New York: New City Press, 2000).

${ }^{2}$ See my discussion on the origin of the two cities in 4.1. Augustine repeats the psychology of humans' aspiring to be God in $C D$ 22.30: "Then shall we be still, and know that He is God: that $\mathrm{He}$ is what we ourselves desired to be when we fell away from Him".
} 
including the human experience in Hell. Section five (5.5) will explore the relation between the deified gods and God and will provide a general description of Augustine's approach to the issue of deification. In the last section (5.6), I shall review the claim by some Orthodox theologians that Augustine does not offer a correct deification theory, as he is blind to the divine essence/energy distinction. Evaluating this discussion, I proceed to focus on Augustine's doctrine of the deification of emotions, analysing the validity of the critics' claim that his position regarding the eschatological fulfilment is confined to the human beatitude.

\subsection{Augustine's Psychological Approach toward the Trinity}

In De Trinitate, Augustine argues that the three persons, the Father, the Son, and the Holy Spirit, share the same indivisible essence and divinity. However, owing to their eternal intrinsic relations, each of the three differs from the other two. The Father is the Father in relation to the Son, the Son is the Son in relation to the Father, and the Holy Spirit is neither Father nor Son, but is equal to them as the Spirit of the Father and Son. ${ }^{3}$ On the basis of the Nicene Creed, Augustine represents the Trinitarian theology of filioque in which the Spirit proceeds from the Father and the Son and appears as a love that bonds the Father and Son together. ${ }^{4}$ Moreover, Augustine attempts to detect analogies between the Trinitarian relations and some triadic human mental agencies or acts, such as mens-notitia-amor, memoria-intellegentia-voluntas, and amans-quod amaturamor, among others. Scholars offer different critical assessments of Augustine's analogies. One opinion is that Augustine's psychological approach cannot illustrate the essence of the Trinity because he incorrectly places substances and attributes on the same level and uses examples that are not strictly Trinitarian. I shall address this opinion first.

\footnotetext{
${ }^{3}$ See De Trin. 1.4.7.

${ }^{4}$ See De Trin. 15.17.28-29; 7.3.6. Fitzgerald and TeSelle explain that Augustine's notion of filioque was influenced by Hilary, Ambrose, Marius Victorinus, and Athanasius who recognised the eternal procession of the Spirit. Augustine argues that the Spirit proceeds principally from the Father and the Son as the societas or communio between the two. See Allan Fitzgerald, "filioque", in Augustine through the Ages: An Encyclopedia, ed. Allan D. Fitzgerald (Michigan/Cambridge: Eerdmans, 1999), 369; Eugene TeSelle, "Holy Spirit", in Augustine through the Ages: An Encyclopedia, ed. Allan D. Fitzgerald (Michigan/Cambridge: Eerdmans, 1999), 434-436.
} 
William Shedd, a famous nineteenth-century theologian, claims that the analogies that Augustine employs fail to illustrate the essence of the Trinity in his last eight chapters of De Trinitate. ${ }^{5}$ In Shedd's annotations on this work, he presents a survey on the three triads that Augustine often adopts. In the triad of the lover, the loved and love, Shedd attends to the properties of these concepts, suggesting that the last term "love" (amor) is essentially different from the first two, as it stands for an attribute rather than a substance, as the terms "the lover" and "the loved" do, respectively. ${ }^{6}$ Shedd states that the same holds for the second triad of the mind, knowledge, and love, as the mind refers to a substance, while knowledge and love refer to its functions. ${ }^{7}$ Shedd emphasises that the two different types of objects, substances and attributes, are mistakenly treated by Augustine as substances. ${ }^{8}$ As an evidence, Shedd refers to Augustine's assertion in De Trinitate 9.4.5 that "love and knowledge exist substantially, as the mind itself does". ${ }^{9}$ This mistake, Shedd notes, derives from Augustine replacing the term "quaedam" (thing) with "substance" in an ambiguous way:

The ambiguity of the Latin contributes to this error. The mind and its loving, and also the mind and its cognizing, are denominated "duo quaedam"; the mind, love, and knowledge, are denominated "tria quaedam". By bringing the mind and its love and knowledge under the one term "quaedam", and then giving the meaning of "substance" to "thing", in "something", the result follows that all three are alike and equally "substantial". ${ }^{10}$

\footnotetext{
5 "Augustine is prolix, repetitious, and sometimes leaves his theme to discuss cognate but distantly related subjects. This appears more in the last eight chapters, which are speculative, than in the first seven, which are scriptural...He discusses many themes which are not strictly trinitarian". De Trinitate, in Nicene and Post-Nicene Fathers III, transl. Haddan and annot. Shedd (New York 1887; Reprint by Eerdmans in 1998), 10. Shedd emphasises the weakness and limitation of Augustine's analogies in illustrating the essence of the Trinity. See Shedd's annotations to De Trin. IX and X in particular. Shedd's view is echoed by some critics such as Oswald Bayer who insists that Augustine's psychological doctrine of the Trinity cannot find theological justification, "if only because it inevitably leads to equivocations". See Oswald Bayer, "The Plurality of the one God and the Plurality of the Gods", in Pro Ecclesia 15:3 (Lanham: Rowman \& Littlefield, 2006), 353.

6 "In the case chosen - namely, the lover, the loved, and love - the first two are substances, the last is not. The mind is a substance, but its activity in loving is not". Haddan and Shedd 1887, 126 (n. 2).

${ }^{7}$ Ibid., 126 (n. 2).

8 "But no psychology, ancient or modern, has ever maintained that the agencies of a spiritual entity or substance are themselves spiritual entities or substances. The activities of the human mind in cognizing, loving, etc., are only its energizing, not its substance”. Ibid., 126 (n. 2).

${ }^{9}$ Ibid., 126 (n. 2). De Trin. 9.4.5: Quamobrem non amor et cognitio tamquam in subiecto insunt menti, sed substantialiter etiam ista sunt sicut ipsa mens quia et si relatiue dicuntur ad inuicem, in sua tamen sunt singula quaeque substantia. Cf. De Trin. 9.4.6: ...substantia sit scientia, substantia sit amor.

${ }^{10}$ Ibid., 126 (n. 2).
} 
As for the third triad - memory, understanding, and will - Shedd declares that this particular triad is better than the above two cases because these three objects are all the faculties of the mind and thus they have equal being. ${ }^{11}$ Nonetheless, this case also has weaknesses, such as failing to display the Trinitarian distinctiveness and being unable to embrace all the functions of the mind such as imagination. ${ }^{12}$ Shedd holds that Augustine's analogical approach is philosophical speculation rather than a scriptural exegesis on the word of God. From this perspective, Augustine's discussion appears deficient in that it concentrates on the terms and their arrangement rather than on the dogma itself. Thus, Augustine's approach leads to prolix and irrelevant illustrations in the second part of his treatise De Trinitate..$^{13}$

Some related weaknesses in Augustine's psychological analogies are also mentioned by Alister McGrath, who states that the Trinity cannot be simplified into three allegedly analogous entities in the human mind; Augustine's method is "illustrative", not "constitutive". ${ }^{14}$ From McGrath's perspective, Augustine considers humanity to be the image of the Trinity so that it is possible to trace the Trinity through its imprints on the human mind. This search occurs within one's inner spiritual world rather than with regard to any external relationships. ${ }^{15}$ McGrath claims that Augustine's triadic illustration is grounded on the Neoplatonic view of regarding the intellect as the apex of humanity that is interpreted in the light of the doctrine of the creation of man as the image of

\footnotetext{
${ }^{11}$ Ibid., 143 (n. 1).

12 "The ternary of memory, understanding, and will is an adequate analogue to the Trinity in respect to equal substantiality. But it fails when the separate consciousness of the Trinitarian distinctions is brought into consideration. The three faculties of memory, understanding, and will, are not so objective to each other as to admit of three forms of consciousness, of the use of the personal Father, Son, and Holy Spirit. It also fails, in that these three are not all the modes of the mind. There are other faculties: e.g., the imagination. The whole essence of the mind is in this also". Ibid., 143 (n. 1).

13 "The second, or speculative division of the work, is that which will be most foreign to the thinking of some trinitarians. In it they will find what seems to them to be a philosophy, rather than an interpretation of the word of God...It has its defects; but they pertain to the form more than to the matter; to arrangement and style more than to dogma". Ibid., 6 and 10.

14 "There are some obvious weaknesses here, possibly even some fatal weakness. As has often been pointed out, the human mind cannot be reduced to three entities in quite this neat and simplistic manner. In the end, however, it must be pointed out that Augustine's appeal to such 'psychological analogies' is actually illustrative, rather than constitutive". Alister McGrath, Christian Theology: An Introduction (3rd edition) (Oxford: Blackwell, 2001), 333.

${ }^{15}$ McGrath 2001, 333.
} 
God. ${ }^{16}$ In the fallen state, the correlation between human psychology and the triune model remains prominent: "The human mind is an image - inadequate, to be sure, but still an image - of God himself". ${ }^{17}$ McGrath distances himself from Shedd's position in arguing that Augustine's appeal to psychological aids in seeking the image of the Trinity is "not ultimately grounded in his analysis of the human mind, but in his reading of Scripture, especially of the fourth gospel". ${ }^{18}$

Lewis Ayres remarks that to Augustine, any direct analogy or conceptualisation is bound to fail in revealing the essence of the Trinity portrayed in the Scripture as three divine persons, the Father, the Son, and the Spirit. ${ }^{19}$ Ayres cites three reasons as to why it is impossible to fully explicate this highest divine simplicity. Firstly, the Trinitarian persons, the Father, the Son, and the Spirit, form a unity that humans cannot conceive of. Any human account of the Trinity as three or one is thus far removed from the simplicity of God, "the unity of that which is the source of all, is the source of order and number in the world, but cannot be itself numbered". ${ }^{20}$ Secondly, the divine simplicity involves an essential relationship among the Father, Son, and Spirit, but this related divine reality cannot be addressed through the human notions of fatherhood and sonship. ${ }^{21}$ Each of the three divine persons exists in an eternal relation to the other two, and yet each of them is also the fullness of the one God without constituting three separate Gods. ${ }^{22}$ Thirdly, to Ayres, the triad of memory, intelligence, and will that Augustine adopts in De Trinitate does not aid in understanding the Trinitarian structure because "each divine person is fully all that God is and would have to be their own memory, intelligence, and will". ${ }^{23}$ On the basis of these points, Ayres

\footnotetext{
16 "On the basis of his neo-Platonic worldview, Augustine argues that the human mind is to be regarded as the apex of humanity. It is therefore to the individual human mind that the theologian should turn, in looking for 'traces of the Trinity' in creation”. Ibid., 333.

${ }^{17}$ Ibid., 333.

${ }^{18}$ McGrath 2001, 333.

19 “...for Augustine there cannot be any direct analogy between the nature of God and the world that we know - either the material world or the world of the mind - because the divine reality is the unique source of all that escapes the categories intrinsic to the creation". Lewis Ayres, "Augustine on the triune life of God", in The Cambridge Companion to Augustine (second edition), ed. David Vincent Meconi and Eleonore Stump (Cambridge: Cambridge University Press, 2014), 70.

${ }^{20}$ Ayres 2014, 70.

21 "The divine simplicity reveals itself to be very important when we think again about the principle that the Father (for example) is named in relationship the Son. For human beings, relationships are not of their essence". Ayres 2014, 70.

${ }^{22}$ Ayres 2014, 71 and 74.

${ }^{23}$ Ayres 2014, 74.
} 
concludes that according to Augustine, some sporadic and vague likeness of God is found in human psychology but it cannot help us grasp the divine reality in this life. $^{24}$

If Augustine is well aware of the limitation of using psychological triads in tracing the nature of the Trinity, ${ }^{25}$ why does he adopt this uncertain and ambiguous approach in his discussion on the ineffable being? Is his psychological consideration grounded on a biblical foundation, or is it merely philosophical speculation? Before proceeding to address these issues, let us see in which context Augustine discusses the Trinitarian structure using the terminology of the Father, the Son, and the Holy Spirit.

\section{The terminological aspects of Trinitarian theology}

The Scripture contains neither the term Trinity nor a direct presentation of the doctrine of the Trinity, but it does refer to the Father, the Son and the Holy Spirit. The terminology related to these three persons is employed in the Catholic faith of the Trinity that Augustine addresses in his De Trinitate 1.4.7:

...to teach in accordance with the Scriptures that the Father, the Son, and the Holy Spirit constitute a divine unity of one and the same substance in an indivisible equality. Therefore, they are not three gods but one God; although the Father has begotten the Son, and, therefore, He who is the Father is not the Son; and the Son was begotten by the Father and, therefore, He who is the Son is not the Father; and the Holy Spirit is neither the Father nor the Son, but only the Spirit of the Father and the Son, and He Himself is also co-equal with the Father and the Son and belongs to the unity of the Trinity. ${ }^{26}$

Shedd contends that the terms Father, Son, and Spirit are, as he defines them, “...literal, not metaphorical; because the relations denoted by them are eternally in the essence". ${ }^{27} \mathrm{He}$ asserts that the language of the scriptural, divine terms of

\footnotetext{
24 "In the case of the relationship between God and anything created we cannot grasp proportions and thus there can be no analogies... The more we see how Augustine thinks the divine simplicity is beyond our comprehension, the more we see why he thinks that only vague 'likenesses' to the divine life can be found in our world and experience". Ayres 2014, 70.

${ }^{25}$ De Trin. 15.27.48-50.

${ }^{26}$ De Trin. 1.4.7: ...hoc intenderunt secundum Scripturas docere, quod Pater et Filius et Spiritus Sanctus unius substantiae inseparabili aequalitate diuinam insinuent unitatem, ideo que non sint tres Dii sed unus Deus - quamuis Pater Filium genuerit, et ideo Filius non sit qui Pater est; Filius que a Patre sit genitus, et ideo Pater non sit qui Filius est; Spiritus que Sanctus nec Pater sit nec Filius, sed tantum Patris et Filii Spiritus, Patri et Filio etiam ipse coaequalis et ad Trinitatis pertinens unitatem.

${ }^{27}$ Haddan and Shedd 1887, 6.
} 
Father and Son denote eternal paternity and sonship. ${ }^{28}$ While this literal realistic account of the subsisting relationship (relatio subsistens) sounds plausible, it is also problematic, as each of the divine persons is fully all that God is. Ayres mentions this in his discussion on the flaws of this interpretation:

Augustine argues that when we say each of the divine three is God we are saying each of the divine three is the fullness of what it is to be God - each is in some sense the one God!...there can only be one divine life, only one unique source of all, and so we are forced logically to assert the paradox that each of Father, Son, and Spirit must be irreducibly fully God and yet each must also be one God. And yet each is also inseparably the one God with the other two. ${ }^{29}$

Besides this difficulty regarding sameness and difference, the realist interpretation also involves some other problems pertaining to the standard views of relations and linguistic meanings.

It is difficult to insert a third personified figure into the Father-Son model and determine the derivative relations between them. For instance, in the Eastern account of the Trinity, the Spirit only proceeds from the Father, but this interpretation poses problems because it contains no distinction between the Son coming from the Father and the Spirit coming from the Father, which would in turn lead to the conclusion that God the Father has two sons. ${ }^{30}$ Therefore, the Eastern approach is inadequate for illustrating the mutual relations between the two hypostases, the Spirit and the Son. In order to avoid the awkwardness of adding another "son", Augustine prefers to regard the Spirit as the love that joins the Father and Son together. However, this would result in two fountainheads of divinity. ${ }^{31}$

Furthermore, the language of the Father and Son does not exclusively define the first and the second hypostasis of the godhead because apart from this pattern, some other images such as "light from light" and "Wisdom-Word-

\footnotetext{
28 "Scripture clearly teaches that the Father is such from eternity. Consequently, 'paternity' can no more be ascribed to the first person of the Godhead in a figurative sense, than eternity can be...The terms Father, Son, and Spirit, in the baptismal formula and the apostolic benediction, must designate primary and eternal distinctions". Ibid., 6.

${ }^{29}$ Ayres 2014, 74.

${ }^{30}$ McGrath writes, "A failure to distinguish the ways in which Son and Spirit derive from the one and the same Father would lead to God having two sons, which would have raised insurmountable problems". See McGrath 2001, 340.

${ }^{31}$ McGrath 2001, 341.
} 
Spirit" ${ }^{32}$ are also used. All of these symbols may reveal some aspects of the Trinitarian relations, but they nevertheless fail to equal the ontological structure. ${ }^{33}$

However, it is equally erroneous to regard the Father, Son, and Spirit merely as names with no reference to the substantive hypostases which would lead to the heresy of Sabellianism. As Augustine warns in $C D$ 11.10:

Nor, as the heretics who follow Sabellius have supposed, is it a Trinity in name only, having no distinctly subsisting Persons. Rather, it is called simple because it is what it has, except insofar as one Person is spoken of in relation to another. ${ }^{34}$

Therefore, the terms Father, Son, and Spirit are neither literal expressions within the realm of human understanding, nor merely names without a connection to reality. The real essence of the Trinity is beyond the human conception of relations and language. Even though we are familiar with the language of the "Father" and "Son" that Jesus uses, the real divine structure and spirituality remain hidden from us until the moment of seeing God "face to face" (faciem ad faciem). ${ }^{35}$

\section{The intention of using psychological triads}

After exploring the biblical Trinitarian expressions in books 1-4 and the doctrinal matters in books 5-7 of De Trinitate, Augustine turns to tracing some likenesses of the Trinity in the human mind. His approach seems speculative and loose, and occasionally he even diverges from the main theme, which has provoked much criticism. Augustine himself recognises these problems, and in the Preface to the second book of De Trinitate, he confesses that this seeking is "roughly exercised", and suggests that errors might be defensible in the investigation of an unapproachable secret. ${ }^{36}$ He repeats this argument in the last part of the treatise:

\footnotetext{
${ }^{32}$ McGrath notes that while the three terms, Word, Wisdom, and Spirit, often appear in the Old Testament as "personifications" or "hypostatizations" of God, they do not equal the Trinity in the strict sense. See McGrath 2001, 320.

${ }^{33}$ De Trin. 1.10.21: Haec uobis locutus sum in similitudinibus; ueniet hora quando iam non in similitudinibus loquar uobis, sed manifeste de Patre nuntiabo uobis; id est iam non erunt similitudines cum uisio fuerit facie ad faciem. Cf. John 16:25.

${ }^{34}$ CD 11.10: Sicut Sabelliani haeretici putauerunt; sed ideo simplex dicitur, quoniam quod habet hoc est, excepto quod relatiue quaeque Persona ad alteram dicitur.

${ }^{35}$ Augustine further explains in his City of God that such "seeing" occurs through the "face" of the inner man (interioris hominis facies) rather than our corporeal face. CD 22.29: Et illud, quod ait apostolus: Faciem ad faciem, non cogit ut Deum per hanc faciem corporalem, ubi sunt oculi corporales, nos uisuros esse credamus, quem spiritu sine intermissione uidebimus.

${ }^{36}$ Prooemium to De Trin. 2: Cum homines Deum quaerunt et ad intellegentiam Trinitatis pro
} 
I venture to acknowledge openly that I have said nothing worthy of the ineffability of that highest Trinity, among all these many things that I have already said, but confess rather that its sublime knowledge has been too great for me, and that I am unable to reach to it. ${ }^{37}$ This unattainability, Augustine explains, is derived from the deep divide between human and divine nature, "a nature that is made is always less than He who made it". ${ }^{38}$ Augustine holds that the human mind cannot equal God and this "unlikeness" (dissimilitudo) is eternal. ${ }^{39}$ However, despite this qualitative gap, the image of God in human beings is not entirely inscrutable, and some likeness (similitudo) is still retained in humanity in accordance with the biblical narrative (specifically, Genesis 1:27). The doctrine of creation in the image of God (imago $D e i)^{40}$ provides a theological foundation for Augustine's explorations of the inner life of the soul, inspiring him to persist in this questioning. ${ }^{41}$ Let us return to his three ternary analogies ${ }^{42}$ to assess their cognitive value.

Regarding the case of the mind, knowledge, and love (mens-notitia-amor), Shedd argues that knowledge and love are the energisers of the mind. The mind is a substance, whereas knowledge and love are its spiritual attributes and cannot be examined on the same level as the substance. This argument seems plausible in terms of lexical meaning, but Shedd's account is nevertheless misguided. When

captu infirmitatis humanae animum intendunt, experti difficultates laboriosas siue in ipsa acie mentis conantis intueri inaccessibilem lucem siue in ipsa multiplici et multimoda locutione litterarum sacrarum (ubi mihi non uidetur nisi atteri Adam ut Christi gratia glorificata dilucescat), cum ad aliquid certum discussa omni ambiguitate peruenerint, facillime debent ignoscere errantibus in tanti peruestigatione secreti.

${ }^{37}$ De Trin. 15.27.50: Uerum inter haec quae multa iam dixi et nihil illius summae Trinitatis ineffabilitate dignum me dixisse audeo profiteri, sed confiteri potius mirificatam scientiam Eius ex me inualuisse nec potuisse me ad illam. Cf. Psalm 139:6.

${ }^{38}$ De Trin. 15.16.26: Semper enim natura minor est faciente, quae facta est.

${ }^{39}$ De Trin. 15.16.26: Quamobrem cum tanta sit nunc in isto aenigmate dissimilitudo Dei et Uerbi Dei in qua tamen nonnulla similitudo comperta est, illud quoque fatendum est quod etiam cum similes ei erimus quando Eum uidebimus sicuti est (quod utique qui dixit hanc procul dubio quae nunc est dissimilitudinem attendit), nec tunc natura Illi erimus aequales.

${ }^{40}$ For the scriptural basis of this doctrine, see McGrath 2001, 440-443.

${ }^{41}$ Augustine explains that his motivation lies in the virtue of scriptural teachings such as "You who seek God, your hearts shall live" (Psalm 69:32) and "see His face evermore" (Psalm 105:4), among others. See De Trin. 9.1.1.

42 Commentators often use the term "analogy" when referring to Augustine's psychological considerations. Augustine himself does not use this term. Some critics prefer to avoid it because it implies that Augustine would offer analogical knowledge (See Peter King, "Augustine's Trinitarian Examples", in Medioevo 37 (2012), 83-106). I think that the idea of an analogy is not entirely alien to Augustine. In his time, "analogy" referred to "a direct line of similarities" of relations (see McGrath 2001, 253-256), and Augustine seems to think that it is reasonable to consider the Trinitarian persons as relations and that these relations form a unity somewhat similarly to the relations that are included in intellectual acts. 
Augustine refers to the mind, it is not to be understood as a static entity, but rather as something that is involved in reflective activities (for instance, knowledge of itself and love of itself). Augustine explains this notion in De Trin. 9.4.4:

But as there are two things (duo quaedam), the mind and the love of it, when it loves itself; so there are two things, the mind and the knowledge of it, when it knows itself. Therefore the mind itself, and the love of it, and the knowledge of it, are three things (tria quaedam), and these three are one; and when they are perfect they are equal. ${ }^{43}$ [transl.

Rev. A. W. Haddan]

The concept of the mind does not stand for a substance in such a way as Shedd assumes. He proposes that the "mind" refers to a substance that has spiritual activities, asserting that a spiritual attribute is not the substance that supports it. ${ }^{44}$ On this basis, he contends that Augustine erroneously replaces the term "quaedam" (thing) with the term "substance", misrepresenting "mind", "love", and "knowledge" as equally "substantial". However, Shedd does not realise that Augustine is interested in the mind as consciousness, the acts of which involve subjective awareness of oneself. This is the source of inseparability and correlation in the ternary of mind, knowledge, and love in Book IX (De Trin. 9.4 in particular). ${ }^{45}$

This correlative model also applies to the case of the lover, the loved, and love (amans-quod amatur-amor). "The lover" casts light on "the loved" and the concept of "love" reveals the relation between "the lover" and "the loved". The notion of "the loved" likewise makes sense only when it involves the bond of love and the lover. When Augustine refers to the term "substance" in this context, his intention is to reveal the functioning relationship between substantial terms rather than a separate entity. To avoid an unnecessary misunderstanding by the reader of

\footnotetext{
${ }^{43}$ De Trin. 9.4.4: Sicut autem duo quaedam sunt, mens et amor eius, cum se amat; ita quaedam duo sunt, mens et notitia eius, cum se nouit. Ipsa igitur mens et amor et notitia eius tria quaedam sunt, et haec tria unum sunt, et cum perfecta sunt aequalia sunt. I adopt Haddan's translation here, as McKenna and Matthews's version is not exact on this point.

44 "In the case chosen - namely, the lover, the loved, and love - the first two are substances, the last is not. The mind is a substance, but its activity in loving is not...The activities of the human mind in cognizing, loving, etc., are only its energizing, not its substance". Haddan and Shedd 1887,126 (n. 2).

${ }^{45}$ De Trin. 9.4.6: “...the lover and the love, or the knower and the knowledge, are spoken of in relation to each other as are friends; yet mind or spirit are not relative terms, as men are not; in spite of this, the lover and the love, and the knower and the knowledge, cannot be separated from each other as men can be who are friends". [transl. McKenna and Matthews] For Augustine's view of the human mind as a self-thinking subject, see Gareth B. Matthews, Thought's Ego in Augustine and Descartes (New York: Cornell University Press, 1992).
} 
"substance", Augustine clarifies the concept of "the loved" ("the lover" and "the loved" pertain to the same thing $)^{46}$ and "love" in the following statement:

And if love is a substance, it is certainly not body but spirit; the mind is not body but spirit. Yet love and mind are not two spirits, but one spirit; not two essences, but one essence; and still the two are one, the lover and the love, or, so to say, the beloved and the love. And these two are truly said to be mutually related. The lover is referred to the love and the love to the lover. For the lover loves with some love, and love is of someone who loves. ${ }^{47}$

"Love" is considered to be a substance that Augustine prefers to refer to as "the mind", the functioning faculty of reflective acts. This correlation is thus understood in terms of substantial sameness. Augustine's aim is to illustrate the relation between the connectivity (such as love) and the acting subject (namely, he who loves) in the interactive structure. So the triad of the lover, the loved, and love presents an equal substantiality (that is, the love of the self of he who loves) in Augustine's argumentation.

The third example of memory, understanding, and will, further illustrates the members sharing the same substantiality, as Shedd notes, but this substantiality is also embedded in different respects of that basic property of the faculty of the mind, the consciousness. Augustine elaborates on their triune relations in De Trin. 10.11.18:

...these three are one in that they are one life, one mind, one essence. And whatever else they are called in respect to themselves, they are spoken of together, not in the plural but in the singular. But they are three in that they are mutually referred to each other. And if they were not equal, not only each one to each one, but each one to all, they would certainly not comprehend each other. For not only is each one comprehended by each one, but all are also comprehended by each one. ${ }^{48}$

\footnotetext{
${ }^{46}$ He explains in De Trin. 9.2.2: "For the lover and the beloved are one and the same when one loves oneself...But it is one thing to love oneself and another thing to love one's love. For love is not loved unless as already loving something; for where nothing is loved, there is no love. Hence, when anyone loves himself there are two: the love and what is loved; for here the lover and the beloved are one".

${ }^{47}$ De Trin. 9.2.2: Et si aliqua substantia est amor, non est utique corpus sed spiritus, nec mens corpus sed spiritus est. Neque tamen amor et mens duo spiritus sed unus spiritus, nec essentiae duae sed una; et tamen duo quaedam unum sunt, amans et amor, siue sic dicas, quod amatur et amor. Et haec quidem duo relatiue ad inuicem dicuntur. Amans quippe ad amorem refertur et amor ad amantem; amans enim aliquo amore amat, et amor alicuius amantis est.

${ }^{48}$ De Trin. 10.11.18: Uita est autem unaquaeque ad se ipsam et mens et essentia. Quocirca tria haec eo sunt unum quo una uita, una mens, una essentia; et quidquid aliud ad se ipsa singula dicuntur etiam simul, non pluraliter sed singulariter dicuntur. Eo uero tria quo ad se inuicem referuntur. Quae si aequalia non essent non solum singula singulis sed etiam omnibus singula,
} 
Augustine explains this further by explicating the first-person mode of memory, understanding, and will as follows:

For I remember that I have memory, understanding, and will; and I understand that I understand, will, and remember; and I will that I will, remember, and understand. At the same time I remember my whole memory, understanding, and will...Wherefore, when all are mutually comprehended by each one, and are comprehended as wholes, then each one as a whole is equal to each other one as a whole, and each one as a whole is equal to all together as wholes; and these three are one life, one mind, one essence. ${ }^{49}$

Augustine states that memory, understanding, and will are the three activities of the mind that reveal the same essence and life of the mind. Thus, memory, understanding, and will constitute three distinct modes of the consciousness that are present in the same essence of the functioning mind. While Augustine's argumentation is persuasive, one could remark that besides these three modes of the mind, imagination and perception are also significant powers that could be involved. However, this criticism neglects the fact that Augustine only addresses the higher levels of the soul, and imagination as a sensual function of psychology cannot be aligned with higher mental acts, such as volition, memory, and understanding. ${ }^{50}$ The same applies to perception. ${ }^{51}$ It is therefore reasonable for Augustine to arrange the cognitive activities of the mind in one unit rather than include other lower types.

From the above three cases, it is evident that Augustine's arrangement of the ternaries is not arbitrary. He carefully anchors the three analogies in the concept of the mind and explores the chosen entities in the relational structure. Referring to the doctrine of the image of God, Augustine examines the inner life (interius) of the human mind in order to seek the image of the Trinity, but he is

non utique se inuicem caperent. Neque enim tantum a singulis singula, uerum etiam a singulis omnia capiuntur.

${ }^{49}$ De Trin. 10.11.18: Memini enim me habere memoriam et intellegentiam et uoluntatem, et intellego me intellegere et uelle atque meminisse, et uolo me uelle et meminisse et intellegere, totam que meam memoriam et intellegentiam et uoluntatem simul memini...Quapropter quando inuicem a singulis et tota et omnia capiuntur, aequalia sunt tota singula totis singulis et tota singula simul omnibus totis, et haec tria unum, una uita, una mens, una essentia.

${ }^{50}$ Mary Clark notes that animus, mens, and anima are distinguished in Augustine. Animus and mens refer to the rational part of soul, while anima refers to the lower, sensual part. As the highest level of the soul, mens (mind) includes cognitive activities such as volition, affection, knowledge, and remembering, which are different from "the fabrication of images". See Mary Clark, "De Trinitate", in The Cambridge Companion to Augustine, ed. Eleonore Stump and Norman Kretzmann (Cambridge: Cambridge University Press, 2001). 97-98.

${ }^{51}$ For Augustine's view of perception and imagination, see O'Daly 1987, 80-130. 
well aware of the weakness of the human mind and spirituality and that these cannot equal divine things and whose similarities to Trinitarian dynamics are ambiguous until the moment of seeing God face to face. ${ }^{52}$ Augustine's repetitious argumentation attempts to encourage readers to envision the image of the Trinity rather than present the Trinitarian structure on an ontological level. This approach, as Alister McGrath observes, is "illustrative rather than constitutive". 53

In discussing the Trinity, the terms Father, Son, and the Holy Spirit refer to the three hypostases of the Godhead, which are different subsistent relations in one simple divinity. Augustine states emphatically that his comments about the Trinity do not comprise a theory that would make the mystery understandable, but he does consider it possible to clarify some aspects of the Catholic doctrinal picture by attending to relational phenomena in psychology. Being very interested in self-awareness and reflexivity, Augustine was led to think that the relations of knowledge and love between the subject and the object can also be applied to the cases when the subject and object are the same, the relation being a third in the same whole. To Augustine, this indicates that the creative order includes some sort of trinities that one becomes easily acquainted with. While this knowledge is only about relations in psychology, Augustine considered them to be analogical attributes in the Trinity and that his analysis may offer a vague picture of the Trinitarian persons as relations. In this sense, his Trinitarian examples are appropriate and persuasive. It is of some interest that Augustine endeavours to clarify the Trinity by analysing the human experience of love. I shall deal with the question of divine emotion in the next section.

\subsection{Human Passions as a Confused Image of God's Metaphorical Emotions}

As part of the image of God in human psychology, one clue for understanding the spiritual nature of God can be found in emotions. ${ }^{54}$ In attempting to define the role

\footnotetext{
${ }^{52}$ De Trin. 14.19.25: Imago uero quae renouatur in spiritu mentis in agnitione Dei non exterius sed interius de die in diem, ipsa perficietur uisione quae tunc erit post iudicium facie ad faciem, nunc autem proficit per speculum in aenigmate.

${ }^{53}$ McGrath 2001, 333.

${ }^{54}$ Paul Gavrilyuk provides an exploration on patristic thoughts upon the doctrine of God from the point of view of emotions. He argues that some Fathers, such as Tertullian, Lactantius, Novatian
} 
of emotions in the image of God, Augustine detects some inconsistencies in the relevant biblical narratives. On the one hand, God is transcendent and immutable and this seems not to be compatible with human variable sentiments. On the other hand, God expresses similar passions as humans, such as jealousy, anger and regret. ${ }^{55}$ How can there be emotions in divinity and how is God's nature imitated in human passions? Let us begin with Augustine's position on God's (im)passibility.

\section{Is God emotional or impassible?}

At the beginning of the first book of Augustine's De Trinitate, he introduces three classes of people who attempt to understand divine nature. The first class endeavors to find God by beginning from corporeal matters. This class of people uses their experiences and senses to grasp incorporeal reality. They imagine God with the help of sensory representations. ${ }^{56}$ The second class frames a view of God by referring to human mentality and affections, and extends the human attributes and habits to include God, such as the characteristics of occasionally forgetting and remembering things. ${ }^{57}$ The third class is not attracted to corporeal matters or human psychology in developing their minds to conceive of the immutable being, but they formulate false conceptions, such as God having the power to generate Himself. ${ }^{58}$ According to Augustine, due to limitations in their mortal thinking, all

and Cyril of Alexandria, are of the opinion that God has certain divine emotions such as anger (toward the unrepentant sins) in the eternal sense, especially Tertullian. "He goes so far as to admit that 'human soul has the same emotions and sensations as God', and these emotions are a part of divine image (imago dei) in human beings". See Paul L. Gavrilyuk, The Suffering of the Impassible God: The Dialectics of Patristic Thought (New York: Oxford University Press, 2004), 58.

${ }^{55}$ For instance, "I am a jealous God" (Exodus 20:5) and "I regret that I made man" (Genesis 6:7). See De Trin. 1.2.

${ }^{56}$ De Trin. 1.1: Quorum nonnulli ea quae de corporalibus rebus siue per sensus corporeos experta notauerunt, siue quae natura humani ingenii et diligentiae uiuacitate uel artis adiutorio perceperunt, ad res incorporeas et spiritales transferre conantur ut ex his illas metiri atque opinari uelint...Qui enim opinatur Deum, uerbi gratia, candidum uel rutilum, fallitur; sed tamen haec inueniuntur in corpore.

${ }^{57}$ De Trin. 1.1: Sunt item alii qui secundum animi humani naturam uel affectum de Deo sentiunt, si quid sentiunt, et ex hoc errore cum de Deo disputant sermoni suo distortas et fallaces regulas figunt...Rursus qui opinatur Deum nunc obliuiscentem, nunc recordantem uel si quid huiusmodi est, nihilominus in errore est; sed tamen haec inueniuntur in animo.

${ }^{58}$ De Trin. 1.1: Est item aliud hominum genus, eorum qui uniuersam quidem creaturam, quae profecto mutabilis est, nituntur transcendere ut ad incommutabilem substantiam quae Deus est erigant intentionem...Qui autem putant eius esse potentiae Deum ut seipsum ipse genuerit, eo plus errant quod non solum Deus ita non est sed nec spiritalis nec corporalis creatura. 
three classes deviate from the right path of understanding the highest being. ${ }^{59}$ Augustine maintains that in order to refute these falsities and misinterpretations, the Scripture adapts the language to be suitable even for children:

Consequently, in order that the human mind may be cleansed from errors of this kind, Sacred Scripture, adapting itself to little ones, has employed words from every class of objects in order that our intellect, as though strengthened by them, might rise as it were gradually to divine and sublime things...For, from the things which are found in the creature, the divine Scripture is wont to prepare enticements, as it were, for children. Its purpose is to arouse the affections of the weak, so that by means of them, as though they were steps, they may mount to higher things according to their own modest capacity, and abandon the lower things. ${ }^{60}$

In this narrative style, expressions such as "Protect me under the shadow of thy wings", "I am a jealous God", and "I regret that I made man", 61 are all formulated from the human perspective and serve to enhance human understanding, using the language applied to familiar human things that helps people grasp the right attitude toward God. Although the "emotions" attributed to God are usual in human contexts, they do not represent the real divine realm. Rather, many places of the Scripture reveal God's true immortality and immutable tranquility distinguished from the variableness of the human mind and its passions. ${ }^{62}$ To Augustine, the Bible makes an explicit distinction between the immutability of the Creator and the changeableness of the creatures, with the scriptural language of God's emotions being metaphorical rather than literal.

One might suppose that Augustine includes some emotional states in the divine impassibility, such as anger, and that God would be able to control His emotions so that divine impassibility would be compatible with divine emotions. ${ }^{63}$

\footnotetext{
${ }^{59}$ De Trin. 1.1: Sed mortalitatis onere praegrauati cum et uideri uolunt scire quod nesciunt et quod uolunt scire non possunt, praesumptiones opinionum suarum audacius affirmando intercludunt sibimet intellegentiae uias.

${ }^{60}$ De Trin. 1.2: Ut ergo ab huiusmodi falsitatibus humanus animus purgaretur, Sancta Scriptura paruulis congruens nullius generis rerum uerba uitauit ex quibus quasi gradatim ad diuina atque sublimia noster intellectus uelut nutritus assurgeret...scriptura diuina uelut infantilia oblectamenta formare quibus infirmorum ad quaerenda superiora et inferiora deserenda pro suo modulo tamquam passibus moueretur aspectus.

${ }^{61}$ See McKenna 1963, 4.

${ }^{62}$ See De Trin. 1.2.

63 "Augustine does not deny that God can experience anger. Rather Augustine expresses a common conviction of the Fathers that divine impassibility does not rule out all divine emotions. Instead, divine impassibility entails freedom from and control over those emotional states that humans cannot manage easily. God is impassible in the sense of being immune to the negative
} 
If this were the case, the difference between human and divine emotions would be that God possesses more power to control passions than human beings and $\mathrm{He}$ experiences certain emotions that humans are incapable of. This literal interpretation of divine emotions attempts to offer a new definition of emotions that would not refer to them as mental disturbances, but would preserve some affective features. This interpretation contradicts Augustine's (and his philosophical predecessors') characterisation of passio as a perturbation of the soul, as we have observed in Chapter 2. Moreover, it would give the impression that God's emotions (such as compassion ${ }^{64}$ ) are perfunctory and even hypocritical without a real involvement in changing feeling qualities. Augustine explains the incompatibility of the literal account of divine anger and repentance with the immutability of the divine plan and foreknowledge as follows:

God's anger is not a disturbance of His mind; rather, it is a judgment according to which punishment is visited upon sin. And when He considers and reconsiders, this is only the application of His immutable plan to mutable things: God does not 'repent' of any act as man does, and His decision as to anything whatsoever is as fixed as His foreknowledge of it is certain. But if Scripture did not use such terms, it would not communicate its meaning so clearly to all the race of men for whom it has care. If it did not first bend down and, as it were, descend to the level of the fallen, it would not terrify the proud, arouse the negligent, exercise the inquirer and nourish the intelligent. ${ }^{65}$

To Augustine, the divine repentance in the Bible is a figurative expression that associates a natural change in things with divine providence. ${ }^{66}$ The anthropomorphic expressions of God's love and the economy of salvation include

consequences typically associated with human emotions. Augustine emphasizes that God is not overpowered by anger or by any other perturbation contrary to reason...divine impassibility was quite compatible with certain divine emotions, ever with anger". See Gavrilyuk 2004, 59-60.

${ }^{64}$ Augustine discusses divine compassion in many places such as ench. 32; CD 10.5-6; Serm. 106.4; En. Ps. 32.2.1.11; 32.2.2.28. See Allan Fitzgerald, "God's Mercy", in Augustine through the Ages: An Encyclopedia, ed. Allan D. Fitzgerald (Michigan/Cambridge: Eerdmans, 1999), 557.

${ }^{65}$ CD 15.25: Ira Dei non perturbatio animi eius est, sed iudicium quo inrogatur poena peccato. Cogitatio uero eius et recogitatio mutandarum rerum est inmutabilis ratio. Neque enim sicut hominem, ita Deum cuiusquam facti sui paenitet, cuius est de omnibus omnino rebus tam fixa sententia quam certa praescientia. Sed si non utatur scriptura talibus uerbis, non se quodam modo familiarius insinuabit omni generi hominum, quibus uult esse consultum, ut et perterreat superbientes et excitet neglegentes, et exerceat quaerentes et alat intellegentes.

${ }^{66} C D$ 14.11: "God is, indeed, said to change His decrees; and we even read in the Scriptures that, figuratively speaking, God 'repented'. But such statements reflect a merely human perspective, or refer to something which has in fact happened according to the order of natural causes; they do not detract from the Almighty's foreknowledge of what He will do". (Deus enim etsi dicitur statuta mutare (unde tropica locutione in Scripturis etiam paenituisse legitur Deum), iuxta id dicitur quod homo sperauerat uel naturalium causarum ordo gestabat, non iuxta id, quod se Omnipotens facturum esse praesciuerat). 
anger, repentance, compassion and other divine "emotions", which do not stain the immutability of divine spiritual nature. Yet this is not to say that God does not have free will and the power to take on human mutable emotions in any way; instead, the divine involvement in human sufferings through the incarnation of the second person of the Trinity is a unique fact that aims at delivering sinners from perturbations to the immutable tranquility of the divinity. For Augustine, to inquire whether or not God is emotional or impassible is misleading, as his approach toward the divine "emotions" includes the Trinitarian theology of the paradoxical proposition "the Impassible suffered", which distances it from the Hellenistic and the Semitic conceptions of God as being apathetic or pathetic. I shall proceed to the details of this issue in the next section (5.3).

\section{The relationship between human passions and the divine spiritual status}

The doctrine of the image of God teaches that the human soul was "breathed forth" (afflatus, not proditus) from God. In contrast to the uncreated and immutable nature of God's spirit, the human spirit is created and changeable. ${ }^{67}$ Augustine mentions in Book XIV of the City of God that the first human beings in Paradise were without the disturbances of passions and that their emotional faculties were fully controlled by their rational will. ${ }^{68}$ According to Augustine, this applied even to their sexual acts, "the sexual organs would have been moved by the same command of the will as the other members are. Then, not needing to be aroused by the excitement of passion, man would have poured his seed into his wife's womb in tranquility of mind and without any corruption of her body's integrity". ${ }^{69}$ The tranquility of the soul of the first human beings imitates the divine impassible life and reflects the imprint that God bears on the original

${ }^{67}$ CD 13.24: Sed enim Dei flatus, inquiunt, Dei ore exisse intellegitur, quem si animam crediderimus, consequens erit, ut eiusdem fateamur esse substantiae parem que illius Sapientiae, quae dicit: Ego ex ore altissimi prodii. Non quidem dixit Sapientia ore Dei afflatam se fuisse, sed ex eius ore prodisse...quem corpori hominis inserendo inspirasse uel insufflasse conuenientissime dictus est, incorporeus incorporeum, sed inmutabilis mutabilem, quia non creatus creatum.

${ }^{68}$ CD 14.10: Sed utrum primus homo uel primi homines (duorum erat quippe coniugium) habebant istos affectus in corpore animali ante peccatum, quales in corpore spiritali non habebimus omni purgato finito que peccato, non inmerito quaeritur. Si enim habebant, quo modo erant beati in illo memorabili beatitudinis loco, id est paradiso? Quis tandem absolute dici beatus potest, qui timore afficitur uel dolore? Cf. CD 14.19 and 14.26.

${ }^{69}$ CD 14.26:...sed eo uoluntatis nutu mouerentur membra illa quo cetera, et sine ardoris inlecebroso stimulo cum tranquillitate animi et corporis nulla corruptione integritatis infunderetur gremio maritus uxoris. 
human psychology. However, this image of God became confused when the first humans transgressed the law.

For, because of this sin, human nature was made subject to all the great corruption that we see and feel, and so to death also. What is more, man came to be distracted by turbulent and conflicting emotions, and so became very different from what he had been when he dwelt in Paradise before his sin; though, even them, he lived in an animal body. ${ }^{70}$

Sin introduced the perturbations of emotions that continue to arise due to a distorted hierarchy in the levels of the soul. ${ }^{71}$ As a consequence of this defect, humans cannot live an entirely tranquil and sinless life without divine restoration to the created good state. This also means that turbulences of the soul become a punishment in this life. The natural state of humans has been distorted, which indicates that a chasm is created between God and man. It is therefore inappropriate at this stage to draw an analogy between divine and human emotions and to speculate from a human perspective as to whether God experiences certain special emotions that humans cannot easily manage.

However, human passions provide an indicator for divine spiritual life, although the analogy should not be interpreted to parallel the variable human dispositions with divine attributes, nor should one understand the scriptural utterances of God's emotions as being literally true. Metaphorical divine passions in the Old Testament reveal God's providence as well as other immutable relations with respect to the created order. ${ }^{72}$ This does not imply that He cannot be

\footnotetext{
${ }^{70}$ CD 14.12:... ut tantae corruptioni, quantam uidemus atque sentimus, et per hanc subiaceret et morti ac tot et tantis tamque inter se contrariis perturbaretur et fluctuaret affectibus, qualis in paradiso ante peccatum, licet in corpore animali esset, utique non fuit.

${ }^{71}$ CD 14.19: Hinc est quod et illi philosophi, qui ueritati propius accesserunt, iram atque libidinem uitiosas animi partes esse confessi sunt, eo quod turbide atque inordinate mouerentur ad ea etiam, quae sapientia perpetrari uetat, ac per hoc opus habere moderatrice mente atque ratione... hae, inquam, partes in paradiso ante peccatum uitiosae non erant. Non enim contra rectam uoluntatem ad aliquid mouebantur, unde necesse esset eas rationis tamquam frenis regentibus abstinere. Nam quod nunc ita mouentur et ab eis, qui temperanter et iuste et pie uiuunt, alias facilius, alias difficilius, tamen cohibendo et repugnando modificantur, non est utique sanitas ex natura, sed languor ex culpa.

${ }^{72}$ CD 11.21: ...quod per omnia dicitur: uidit Deus quia bonum est...Et Plato quidem plus ausus est dicere, elatum esse scilicet Deum gaudio mundi uniuersitate perfecta. Ubi et ipse non usque adeo desipiebat, ut putaret Deum sui operis nouitate factum beatiorem; sed sic ostendere uoluit artifici suo placuisse iam factum, quod placuerat in arte faciendum; non quod ullo modo Dei scientia uarietur, ut aliud in ea faciant quae nondum sunt, aliud quae iam sunt, aliud quae fuerunt; non enim more nostro ille uel quod futurum est prospicit, uel quod praesens est aspicit, uel quod praeteritum est respicit; sed alio modo quodam a nostrarum cogitationum consuetudine longe alte que diuerso. Ille quippe non ex hoc in illud cogitatione mutata, sed omnino incommutabiliter uidet.
} 
in contact with human passions in any way. In order to break the chasm between God and man and renew the confused image of God in man, the second person of the Trinity mediates between divine and human emotions through His incarnation. Many questions can be posed here, of course, such as how these two distinct natures function in Him or whether the whole Trinity suffered the crucifixion.

\subsection{Redemption from Earthly Emotions in the Passion of Christ}

Some modern theologians note that the patristic doctrine of the impassible God is derived from the Hellenistic conception of divine apatheia rather than from the Hebrew idea of the passible God. This is said to lead away from the Patripassian position to view God as apathetic. ${ }^{73}$ This account is challenged by other writers who maintain that "the Theory of Theology's Fall into Hellenistic Philosophy" is misleading, as the theme of impassible suffering is revealed in the Christian doctrine and is not derived from pagan philosophers. Let us examine this discussion more closely.

In his The Paradox of a Suffering God, A. G. Nnamani aims to clarify the notion of God in the Greek and the Semitic contexts. Nnamani argues that the early Christian view of divine impassibility stems from the Hellenistic thought of apatheia. ${ }^{74} \mathrm{He}$ examines the origin and development of the doctrine of the divine apatheia in the Greek tradition and maintains that there is a tendency to disparage divine emotions in ancient Greek philosophy and this is in contrast to the endorsement of God's emotional life in the biblical and rabbinical literature. ${ }^{75}$

\footnotetext{
73 This is referred to as the "Theory of Theology's Fall into Hellenistic Philosophy” by Paul Gavrilyuk and he summarises its main elements as follows: "(1) divine impassibility is an attribute of God in Greek and Hellenistic philosophy; (2) divine impassibility was adopted by the early Fathers uncritically from the philosophers; (3) divine impassibility does not leave room for any sound account of divine emotions and divine involvement in history, as attested in the Bible; (4) divine impassibility is incompatible with the revelation of the suffering of God in Jesus Christ; (5) the latter fact was recognised by a minority group of theologians who affirmed that God is passible, going against the majority opinion". See Gavrilyuk 2004, 5 and 176.

74 "We have examined the axiom of divine impassibility in the light of the Hellenistic and Semitic conceptions of God and noted that it stems from the concept of apatheia in the ancient Greek philosophy...The adoption of the Greek concept of divine apatheia is characteristic of the theologies of the first three centuries of the Church. It can indeed be seen as the basic theological presupposition of the patristic Christology and the doctrine of God". A. G. Nnamani, The Paradox of a Suffering God: On the Classical, Modern Western and Third World Struggles to Harmonize the Incompatible Attributes of the Trinitarian God (Frankfurt am Main: Peter Lang, 1995), 56-59. ${ }^{75}$ Nnamani 1995, 40.
} 
Nnamani thinks that apatheia is absent from the Semitic understanding of God. ${ }^{76}$ The tension between these two conceptions of God (impassible and passible) is first addressed in the Hellenisation of Judaism by Philo of Alexandria, who introduced the allegorical method so as to reconcile the clash of these traditions in explaining divine emotions. ${ }^{77}$ According to his allegorical approach, the utterances of wrath and repentance of God in the Old Testament should not be interpreted literally. In contrast, divine compassion is real, but not subject to a change like human passions; divine impassibility and immutability are taken for granted. ${ }^{78}$ Nnamani argues that Philo's conciliation is in defense of the Greek divine apatheia. ${ }^{79}$ Nnamani contends that this allegorical method is adopted by Augustine, who continues to deal with the tension between the two cultural notions, in order to assimilate the biblical notions to divine impassibility. Even though Augustine attempts to leave space for divine passibility by using a "double-pronged" approach, his adherence to the apatheia model is evident. ${ }^{80}$ Nnamani asserts that the endorsement of the Greek impassible theory is the result of "the Hellenisation of Judaism and Christianity". ${ }^{81}$ In his assessment, the dilemma of divine impassibility reflects the "unfinished cultural integration between the Semitic and Hellenistic traditions". ${ }^{82}$

The issue of theology's fall to Greek philosophy has been analysed with considerable seriousness in the twentieth century by theologians such as Adolf von Harnack, Hastings Rashdall, Kazoh Kitamori, Jürgen Moltmann and their

\footnotetext{
76 "In general however, divine apatheia emerges out of the Hellenistic tendency to conceive God by way of negation and through the disparagement of emotions....apatheia in the sense explained above is totally absent in the biblical and Semitic conception of God". Nnamani 1995, 57.

${ }^{77}$ Nnamani 1995, 51, 57 and 58.

${ }^{78}$ Nnamani refers to two places in Philo's writings to show his adoption of the Greek notion of divine apatheia. One is in Quod Deus immutabilis sit v, 22: "there could be no greater impiety than to suppose that the Unchangeable changes"; the other is in Quod Deus immutabilis sit xi, 52: "He is not susceptible to any passions at all". See Nnamani 1995, 53.

79 “...we can rightly say that the first significant attempt to harmonise the Jewish and Greek notions of God began with Philo. He reinterprets the anthropomorphic expressions of the Bible in defence of the concept of divine apatheia". Nnamani 1995, 53.

80 "St. Augustine makes optimal effort to show that God's emotions do not interfere with His immutability. He does this employing Philo's allegorical method". Nnamani 1995, 86. Nnamani believes that Augustine adheres to the axiom of divine impassibility and, in this framework, the possibility of divine passibility is also permitted. But Nnamani notes that like Philo, the dilemma of the divine impassibility is not addressed satisfactorily in Augustine either. See Ibid., 86-87.

81 "Reconciling these two contrary conceptions of God - of a pathetic and an apathetic God - has been a consistent preoccupation of theology since the Hellenisation of Judaism and Christianity". Nnamani 1995, 57.

${ }^{82}$ Ibid., 56.
} 
followers. These scholars worried about the distortion of the gospel by the philosophical prism and challenged the traditional position on the impassibility of God. ${ }^{83}$ For Harnack, the Hellenistic invasion derives from the systematisation of the theological ideas proposed by the Gnostics. ${ }^{84}$ The formation of this doctrinal system occurred as an enculturation of Christianity in the Hellenistic environment that involved the factors of "the speculative philosophical, the cultish-mystical and the dualistic-ascetic" ${ }^{85}$ Harnack explains this as follows:

They [Gnostics] were accordingly a class of Christians who essayed through a sharp onset to conquer Christianity for Hellenic culture, and Hellenic culture for Christianity, and they thereby abandoned the Old Testament in order to fitly close up the breach between the two opposing forces. Christianity became an occult theosophy (revealed metaphysics and apparition philosophy, permeated with the Platonic spirit and with Pauline ideas, constructed out of the material of an old cultus-wisdom which was acquired through mysteries and the illumined understanding, defined by a keen and, in part, true criticism of the Old Testament religion and the scant faith of the Church). ${ }^{86}$

During this doctrinal integration, Harnack suggests, the evangelical account of God was adulterated and implanted by the philosophical metaphysics and this led to a wrong turn in portraying God as impassible. This portrayal was followed by the patristic fathers who criticised Patripassianism. ${ }^{87}$ Harnack's questioning of the classical understanding of God was echoed by his contemporary theologian, Hastings Rashdall. In his Idea of Atonement, Rashdall observes:

\footnotetext{
${ }^{83}$ Gavrilyuk adds that the distortion of the gospel by philosophy was actually noticed by some early Fathers, such as Hippolytus and Tertullian, who accused the Gnostic heretical deviation from the apostolic tradition by adopting Greek philosophy. He refers to Hippolytus's Refutatio ominium heresium (Proem. 3) and Tertullian's De praescriptione haereticorum 7 as sources for the view of the philosophical deformation of the gospel. See Gavrilyuk 2004, 3-4. For the recent discussion on the Fall theory and the doctrine of a suffering God, see the Appendix in Gavrilyuk 2004, 176-179. Cf. McGrath 2001, 273-279.

84 "The gnostics were the theologians of the 1st century; they were the first to transform Christianity into a system of doctrines (dogmas); they were the first to treat tradition and the primitive Christian Scriptures systematically; they undertook to set forth Christianity as the absolute religion, and they therefore placed it in opposition to the other religions, to that of the Old Testament as well (not alone to Judaism); but the absolute religion, which they coupled with Christ, was to them essentially identical with the results of the philosophy of religion". Adolf Harnack, Outlines of the History of Dogma, transl. Edwin Knox Mitchell (London: Hodder and Stoughton, 1893), 60.

${ }^{85}$ Harnack 1893, 61.

${ }^{86}$ Harnack 1893, 60.

${ }^{87}$ Two treatises, Hippolytus's Contra Noetum and Tertullian's Adversus Praxeam included an important criticism of the Patripassian position. For the issue of whether "Pater passus est" is a fictive slogan introduced by anti-Patripassion theologians, see Adolf Harnack, "Monarchianismus", in Realencyklopädie für protestantische Theologie und Kirche, ed. Albert Hauck (Leipzig: J. C. Hinrichs, 1903), 329; Gavrilyuk 2004, 93-100.
} 
We need not be debarred from doing so by the extreme aversion of the patristic and scholastic theologians to think of divinity as 'passible'; for it must be confessed that this aversion of theirs, which the Church took over from Greek thought rather than from Christ or St. Paul, is hard to reconcile with the essential Christian conception of God as a loving Father. The Christian God is not the pure Intelligence-cold, passionless, and loveless, 'Himself unmoved, all motion's source' - that He was to Aristotle. ${ }^{88}$

The conception of the passible God was developed further by Kitamori and Moltmann. They based their views mainly on the pain of God the Father, but unlike the Patripassianist position, which regarded the passion of Son as the suffering of the Father on the cross, Kitamori and Moltmann discerned distinct types of pain in the Father and Son. They explained that the Father was suffering from losing the Son, but the only crucified one was the Son, who suffers pain and death. ${ }^{89}$ For Moltmann, it is a deficiency and weakness if God the Father cannot suffer, because "a God who cannot suffer is poorer than any human". 90

In contrast to the above interpretation, Paul Gavrilyuk asserts that a special theme in Christian theology that is not found in Hellenistic philosophy and mythology is the notion of the suffering of the Impassible. To Gavrilyuk, Christian apologists and Greek philosophers were in the same front in their refuting the traditional mythological vision of passionate gods. ${ }^{91}$ Refuting the position of mythical anthropomorphism and polytheism, the apologists defended the transcendence and supremacy of the divine, arguing that God should be impassible and free from all human passions and desires. ${ }^{92}$ But Gavrilyuk notes that the Christian account of divine impassibility is different from the philosophical formulations. The first difference is that it is not reduced to apathy

\footnotetext{
${ }^{88}$ Hastings Rashdall, The Idea of Atonement in Christian Theology (London: Macmillan, 1919), 452.

${ }^{89}$ McGrath regards the position of Kitamori and Moltmann as distinguished from Patripassianism. "The Father and the Son suffer - but they experience that suffering in different manners. The Son suffers the pain and death of the cross; the Father gives up and suffers the loss of the Son". See McGrath 2001, 278.

${ }^{90}$ Jürgen Moltmann, The Crucified God: The Cross of Christ as the Foundation and Criticism of Christian Theology (London: SCM Press, 1974), 222. Cf. McGrath 2001, 277. For Kitamori's view, see his Theology of the Pain of God (Louisville: John Knox Press, 1965).

91 "The myths spoke of the gods as being endowed with human passions and weaknesses. Happily, Christians were not the only ones who understood the impropriety of ascribing human, all too human, characteristics to gods. Many philosophically minded pagans and Jews shared the same sensibility. Charges of anthropomorphism against the traditional polytheism became commonplace among philosophers from the time of Xenophanes". Gavrilyuk 2004, 48.

92 Gavrilyuk 2004, 49-50.
} 
and indifference. Gavrilyuk suggests that impassibility should be evaluated from the perspective of negative/apophatic theology and treated as a surpassing form of the divinity, which serves as "an apophatic qualifier of divine emotions". ${ }^{93}$ The second difference is that according to patristic theology, divine emotions are compatible with divine impassibility because God is able to control emotions without any negative perturbations: "Divine impassibility was an important apophatic qualifier of all divine emotions that ensured that God experiences them in the manner appropriate to him alone". ${ }^{94}$ The third difference is that the doctrine of the incarnation implies the paradoxical position of the impassible divine being involved in suffering, which is not found in pagan philosophy. Through many dialectical turns against heresies, Gavrilyuk argues, the church fathers defended their belief in the "divine involvement worthy of God". ${ }^{95}$ Gavrilyuk thus believes that patristic theology does not make a choice between the Hellenistic and the Semitic sources of God, but rather follows a dialectical approach of its own. In this sense, the theory of Theology's descent into Hellenistic philosophy cannot be argued convincingly. ${ }^{96}$

The point at issue here is whether the patristic theology adheres to the Hellenistic position on the impassibility of God. In the case of Augustine, the scholars generally agree that he adopts the impassibilist position, but they draw different conclusions. Some scholars declare that Augustine and his predecessors represent the Hellenised reading of the gospel through philosophical concepts that leads to the doctrine of divine apatheia. Some others, such as Gavrilyuk, argue that such a reduction of theology to philosophy does not exist because Augustine's conception of the divine impassibility, as an apophatic qualifier, involves special divine emotions. With these two accounts in mind, let us explore Augustine's position by examining some relevant texts.

\section{The triune spiritual life and the divine kenosis}

Augustine's consideration of God's "emotions" is expressed in his account of the Trinity. He continues to advocate the same substance of the three persons in the

\footnotetext{
${ }^{93}$ Ibid., 47-48; 60-63.

${ }^{94}$ Ibid., 60.

95 Ibid., 172.

${ }^{96}$ Ibid., 2, 5, 172 and 179.
} 
Trinitarian structure, emphasizing their separate roles in indivisible works. In $D e$

Trinitate 15.17.29, Augustine clarifies this in the following way:

Yet it is not without reason that in this Trinity only the Son is called the Word of God, and that only the Holy Spirit is the Gift of God, and that only He, of whom the Son was begotten, and from whom the Holy Spirit principally proceeds, is God the Father. I have added "principally", therefore, because the Holy Spirit is also found to proceed from the Son...therefore, that the common Gift should also proceed from Him, and that the Holy Spirit should be the Spirit of both. This distinction in the inseparable Trinity, therefore, is not to be touched upon in passing, but is to be carefully considered...If, then, any one of these three is to be specially called love, what more fitting than that this should be the Holy Spirit? In the sense, that is, that in that simple and highest nature, substance is not one thing, and love another thing, but that substance itself is love, and that love itself is substance, whether in the Father, or the Son, or the Holy Spirit, and yet that the Holy Spirit is especially called "love". 97

Augustine carefully outlines the distinct roles of the three persons in the Trinity. He identifies the Son as the "Word" (or "Wisdom"), the Spirit as "Love" (or "Gift"), both being from God the Father, but in different manners. The Son was begotten from the Father, while the Spirit proceeds from both the Father and Son as "Love", binding them together. Nevertheless, they share the same substance, which Augustine refers to as love, even though the Holy Spirit is also called love. In Augustine's view, the divine love reveals the spiritual nature of triune life, so "God is love". Love is not therefore confined to the Spirit, but all three persons together are one love. ${ }^{98}$

In his description of the Heavenly life of the City of God, Augustine interprets Psalm 16:11 as the citizens being filled with the divine spirit and having

\footnotetext{
${ }^{97}$ De Trin. 15.17.29: Et tamen non frustra in hac Trinitate non dicitur uerbum Dei nisi Filius, nec donum Dei nisi Spiritus Sanctus, nec de quo genitum est uerbum et de quo procedit principaliter Spiritus Sanctus nisi Deus Pater. Ideo autem addidi, principaliter, quia et de Filio Spiritus Sanctus procedere reperitur... sic ergo eum genuit ut etiam de illo donum commune procederet et Spiritus Sanctus spiritus esset amborum. Non est igitur accipienda transeunter sed diligenter intuenda inseparabilis Trinitatis ista distinctio... Sic ergo proprie aliquid horum trium caritas nuncupanda est, quid aptius quam ut hoc sit Spiritus Sanctus? Ut scilicet in illa simplici summa que natura non sit aliud substantia et aliud caritas, sed substantia ipsa sit caritas et caritas ipsa substantia siue in Patre siue in Filio siue in Spiritu Sancto, et tamen proprie Spiritus Sanctus caritas nuncupetur.

${ }^{98}$ De Trin. 15.17.28: "Therefore, 'God is love'...We should rather so conceive this, that all together possess and each one possesses all three of these in their own nature...I do not know why, as the Father, the Son, and the Holy Spirit are called wisdom, and all together are not three wisdoms but one wisdom, so the Father, the Son, and the Holy Spirit should not be called love, and all together one love. For so is the Father God, the Son God, and the Holy Spirit God, and all together are one God".
} 
the fruition of God with eternal fullness of joy: "Thou shall fill me with joy with thy countenance". ${ }^{99}$ Augustine assures us that this joy will suffice because there is nothing more that we will need (De Trin. 1.8.17: Illa laetitia nihil amplius requiretur quia nec erit quod amplius requiratur). This eternal fullness of joy (aeterna perfectio gaudiorum) ${ }^{100}$ is one of the divine spiritual attributes that humans will attain. ${ }^{101}$ In brief, the immutable fullness of joy, combined with divine inner Trinitarian love reflect the triune spiritual life, but this differs from the human understanding of emotions, for the divine realm is transcendent and inscrutable. It is important to note that to describe divine attributes, Augustine also employs the language of the impassibility of God (impassibilitas Dei), which refers to the immutability and the indescribable (ineffabilis) realm of divinity. ${ }^{102}$ For Augustine, any description of the divine "emotions" is derived from human experiences. ${ }^{103}$ In this sense, the triune "emotional" life, joy and love, which are described as impassible, points to the transcendent spirit of immutable goodness that transcends human cognition.

However, the issue of God's emotions is more complicated than what was just stated because it includes the question of divine involvement in human emotions. In the first two books of his De Trinitate, Augustine maintains that the second person of the Trinity suffered in the incarnation and crucifixion rather than the Father or the Spirit, although they are inseparable and work inseparably. ${ }^{104}$ Augustine proposes that during the incarnation, a specific relation appeared, namely, the Son is both equal to and lesser than the Father, Spirit and Himself:

\footnotetext{
${ }^{99}$ De Trin. 1.8.17: Tunc erit quod Scriptum est: Adimplebis me laetitia cum uultu Tuo.

${ }^{100}$ De Trin. 1.8.17: Haec enim nobis contemplatio promittitur actionum omnium finis atque aeterna perfectio gaudiorum.

${ }^{101}$ I shall continue this discussion in section 5.6.

${ }^{102}$ Augustine stresses the ineffability of the divine impassibility and "emotions" in De patientia 1.1:...quem nihil patientem nec tamen impatientem, immo etiam patientissimum dicimus, uerbis explicare quis possit? Ineffabilis est ergo illa patientia, non tamen nulla, sicut zelus Eius, sicut ira Eius et si quid huius modi est. Gavrilyuk refers to "divine impassibility" as an ontological term. He explains, "I will locate the divine impassibility in the conceptual sphere of apophatic theology. I will show that in apophatic theology impassibility was first of all an ontological term, expressing God's unlikeness to everything created, his transcendence and supremacy over all things, rather than a psychological term implying the absence of emotions. In this conceptual framework divine impassibility safeguarded God's undiminished divinity and transcendence". Gavrilyuk 2004, 48.

${ }^{103}$ E.g., in Enarrationes in Psalmos 2.4: "The 'wrath' of God then is an emotion which is produced in the soul which knoweth the law of God, when it sees this same law transgressed by the sinner". [transl. Coxe]. Cf. CD 15.25.

${ }^{104}$ E.g., De Trin. 1.4.7; 1.5.8; 1.7.14; 2.1.2.
} 
...the Son of God is understood to be equal to the Father according to the form of God in which $\mathrm{He}$ is, and less than the Father according to the form of a slave that He has received. In this form $\mathrm{He}$ has been found to be not only less than the Father but of the Holy Spirit as well, and not only that, but He has been found to be even less than Himself, not of Himself who was, but of Himself who is, because by the form of a slave which He received, He did not lose the form of God... ${ }^{105}$

Augustine argues that this paradoxical manner of existence applies to Christ, owing to "his having emptied Himself" (exinanivit): "Since He [Son], in the form of God being equal to the Father from whom He emptied Himself by taking the form of a slave, acts, suffers, and receives in the form of a slave". ${ }^{106}$ Augustine adopts the kenotic approach to interpret the two natures of the incarnate Son, divinity and humanity. In this case, two distinct natures are involved in one person:

Hence, because the form of God took the form of a slave, then both is God and both is man. But both God on account of the God who takes, and both man on account of the man who is taken. By that taking the one was not turned and changed into the other. For the divinity was not changed into the creature so that it ceased to be the divinity, nor the creature into the divinity so that it ceased to be a creature. ${ }^{107}$

The divine and human spiritual natures are both simultaneously separate and inseparable, which seems to imply that in the suffering of Christ, two distinct "emotional" realities are without division, without confusion, without transformation, and without separation. ${ }^{108}$ This mysterious state conveys the paradoxical slogan of "the Impassible suffered". It is important to note again that the concept of "the impassible" here does not involve an emotional sense that human beings understand, but it refers to God's enigmatic, spiritual nature and His immutable characteristics, such as providence, foreknowledge, love and

\footnotetext{
${ }^{105}$ De Trin. 2.1.2: ...intellegatur Dei Filius et aequalis Patri secundum Dei formam in qua est et minor Patre secundum serui formam quam accepit, in qua forma non solum Patre sed etiam Spiritu Sancto, neque hoc tantum sed etiam Se ipso minor inuentus est, non Se ipso qui fuit sed Se ipso qui est quia forma serui accepta formam Dei non amisit... Cf. De Trin. 1.11.22; 1.13.29.

${ }^{106}$ De Trin. 1.13.29: Ille quippe in forma Dei aequalis est Patri, ex quo Se exinaniuit formam serui accipiens; in ipsa forma serui et agit et patitur et accipit...

${ }^{107}$ De Trin. 1.7.14: Ergo quia forma Dei accepit formam serui, utrumque Deus et utrumque homo; sed utrumque Deus propter accipientem Deum, utrumque autem homo propter acceptum hominem. Neque enim illa susceptione alterum eorum in alterum conuersum atque mutatum est; nec diuinitas quippe in creaturam mutata est ut desisteret esse diuinitas, nec creatura in diuinitatem ut desisteret esse creatura.

${ }^{108}$ For the dogma of two natures in Christ, see Jaroslav Pelikan, The Emergence of the Catholic Tradition (100-600) (Chicago and London: The University of Chicago Press, 1971), 256-266.
} 
justice.

It is therefore apparent that Augustine's vision of God's emotions is neither simply apathetic nor passionate, but belongs to the Trinitarian theology and adopts the classical kenotic approach to Christology. Instead of being a psychological conception to Augustine, impassibilitas Dei refers to the divine transcendence, supremacy and immutability. Hence the idea of impassible suffering transcended the Hellenistic and the Jewish discussion of whether or not God is impassible. Moreover, this statement was embedded in a theological context that was completely unfamiliar to pagan philosophers: the soteriological doctrine of why and how "the impassible" person of Christ suffered for humans.

\section{Divine transaction: Redemption from emotions to take divinity by grace}

In his Exposition 2 of Psalm 30, Augustine clarifies the notion of divine transaction (divina commercia) in the following words:

...he [Christ] who deigned to assume the form of a slave, and within that form to clothe us with himself, he who did not disdain to take us up into himself, did not disdain either to transfigure us into himself, and to speak in our words, so that we in our turn might speak in his. This is the wonderful exchange, the divine business deal, the transaction effected in this world by the heavenly dealer. He came to receive insults and give honors, he came to drain the cup of suffering and give salvation, he came to undergo death and give life. Facing death, then, because of what he had from us, he was afraid, not in himself but in us. When he said that his soul was sorrowful to the point of death, we all unquestionably said it with him. Without him, we are nothing, but in him we too are Christ. ${ }^{109}$

To interpret the reason for divine kenosis, Augustine adopts the concepts of exchange (commutatio) and transaction (commercia). A series of "equivalent" matters are placed on the scales, such as insults and honours, sufferings and salvation, death and life, and the transaction takes place in the Passion of Christ.

\footnotetext{
${ }^{109}$ En. Ps. 30 (Enarratio 2): Uerumtamen quia dignatus est assumere formam serui, et in ea nos uestire se, qui non est dedignatus assumere nos in se, non est dedignatus transfigurare nos in se, et loqui uerbis nostris, ut et nos loqueremur uerbis ipsius. Haec enim mira commutatio facta est, et diuina sunt peracta commercia, mutatio rerum celebrata in hoc mundo a negotiatore caelesti. Uenit accipere contumelias, dare honores; uenit haurire dolorem, dare salutem; uenit subire mortem, dare uitam. Moriturus ergo ex eo quod nostrum habebat, non in se, sed in nobis pauebat; quia et hoc dixit, tristem esse animam suam usque ad mortem, et utique nos ipsi omnes cum illo. Nam sine illo, nos nihil; in illo autem, ipse Christus et nos. Translation in Boulding 2000, 323324.
} 
Augustine attempts to demonstrate that Christ emptied Himself as a slave and absorbed all the human emotions [perturbations of soul], weakness and even death, which implies that as a result of an exchange, participants will receive His divinity and eternal life. ${ }^{110}$

In the person of the crucified Christ, two distinct spiritual natures are involved in implementing the transaction. Based on this business approach and on Augustine's account of the two natures in De Trinitate $1.7 .14,{ }^{111}$ we could infer that the divine spiritual status cannot be stained by human emotions so as to abandon its divine attributes, nor can human emotions shift to divinity so that Christ would lose His human nature. Nonetheless, these two distinct realities cannot be separated, as they are both associated with God and man in the person of Christ.

Through the exchange, humans who live in Christ will abandon the miserable emotions of this life and attain the divinity by sharing the same eternal joyful life in the Kingdom of God. This is not a meritorious human achievement, but derives from God's grace and charity since, to Augustine, the divine life attained in the future is derived from His nature, not our own. He explains this to his congregation as follows:

...He [Christ] is the Selfsame, incapable of any change, we who participate in his divinity shall ourselves be immortal and shaped for eternal life. As I have explained to you already, holy brethren, God gave us a pledge in the person of his Son: before we could become participants in his immortality, he had to become a participant in our mortality. But as he became mortal not because of anything in his own nature but by sharing in ours, so do we become immortal not in the power of our own nature but through his. ${ }^{12}$

The Passion of Christ reveals the divine economy of salvation, in which the Trinitarian persons work inseparably. Nonetheless, this does not mean that the Father or the Spirit were crucified, dead and resurrected, as in the formula held by

\footnotetext{
110 Sermones nouissimi 6D (=23B).1: Gerimus mortalitatem, toleramus infirmitatem, exspectamus diuinitatem. Vult enim Deus non solum uiuificare, sed etiam deificare nos. Quando hoc sperare humana infirmitas auderet, nisi diuina promitteret ueritas?

${ }^{111}$ De Trin. 1.7.14: Neque enim illa susceptione alterum eorum in alterum conuersum atque mutatum est; nec diuinitas quippe in creaturam mutata est ut desisteret esse diuinitas, nec creatura in diuinitatem ut desisteret esse creatura.

${ }^{112}$ En. Ps. 146.5.11: Igitur si ipse idem ipse est, et mutari ex nulla parte potest; participando Eius diuinitatem erimus et nos immortales in uitam aeternam. Et hoc nobis pignus datum est de Filio Dei, quod iam dixi sanctitati uestrae, ut antequam efficeremur participes immortalitatis ipsius, fieret ipse prius particeps mortalitatis nostrae. Sicut autem ille mortalis, non de sua substantia, sed de nostra, sic nos immortales, non de nostra substantia, sed de ipsius.
} 
the Patripassion theologians such as Noetus and Praxeas, ${ }^{113}$ whose position is refuted by Augustine in his De Trinitate $(1.4 .7$; 1.5 .8 ; 1.7 .14 in particular). For Augustine, only the person of Christ who is the mediator between the divine transcendent spiritual state and human emotions is directly involved in the crucifixion. Christ is the redeemer who delivers humans from the earthly emotions to adopt divine, joyful life. God the Father and the Holy Spirit are also involved, but assuming different roles. ${ }^{114}$ However, Augustine does not continue to speculate whether the Father suffered in a different manner. This is because Augustine considers human language and thoughts to be inadequate to capture the nature of God. Therefore the imagery of God as either impassible or not is only human speculation.

It is thus clear that Augustine's approach is fundamentally different from the Hellenistic position. His interpretation is rooted in biblical foundations and anchored in the theological theme of the impassible suffering that is not found in Greek philosophy. Gavrilyuk is right to debunk the misinterpretation of the fall of theology into Hellenistic philosophy and to regard impassibilitas as an ontological term referring to the transcendence of God. Yet his attempt to reconcile the tension between the emotions and apatheia in the divine sphere becomes problematic when he reduces these ontological conceptions to a psychological model, arguing that God has more power than humans in controlling emotions. ${ }^{115}$ For Augustine, the divine realm is far above human cognition and cannot be reduced to the level of the human affective domain. If this were possible, God would be as poor as humans. In the next discussion on the spirituality of angels in eschatology, I shall further explain how the emotions are essentially unworthy of God in Augustine.

\footnotetext{
113 The formula of the Father crucified and suffered is maintained in this school which attempts to defend the notion of one single God, as Noetus argues: "If I acknowledge Christ to be God; He is the Father himself, if He is indeed God; and Christ suffered, being Himself God; and consequently the Father suffered, for He was the Father Himself' (Contra Noetum 2.3). See Gavrilyuk 2004, 93. ${ }^{114}$ De Trin. 1.4.7: Non tamen eandem Trinitatem natam de uirgine Maria et sub Pontio Pilato crucifixam et sepultam tertio die resurrexisse et in caelum ascendisse, sed tantummodo Filium... Nec eandem Trinitatem dixisse de caelo: Tu es Filius meus... sed tantummodo Patris uocem fuisse ad Filium factam-quamuis Pater et Filius et Spiritus Sanctus sicut inseparabiles sunt, ita inseparabiliter operentur.

115 See Gavrilyuk 2004, 59-63.
} 


\subsection{Division of Angels and Emotions as Punishments in Hell}

As explained in the previous chapter, the division between the two cities derives from the depravity of some angels who abandoned God to exercise their own desire and glory. ${ }^{116}$ Augustine proceeds to identify this event from the biblical text. In his exegesis of Genesis 1:4, Augustine portrays the division of light and darkness as the separation of the angels:

Now it does not seem to me an absurd interpretation of God's works if we understand that the angels were created when that first light was made, and that the separation of the holy and the unclean angels was made when, as is said, 'God divided the light from the darkness; and God called the light Day, and the darkness He called Night'...But as regards that 'light' which is the holy company of the angels, intelligibly refulgent with the illumination of truth, and that opposite 'darkness' which designates the most loathsome minds of those wicked angels who are turned away from the light of righteousness: only God Himself could divide these from one another; for the future evil of the wicked angels - not a defect of their nature, but of their will — could not be hidden from Him or unknown to Him. ${ }^{117}$

Augustine asserts that the divine testimony of "Let there be light" (fiat lux) implies the creation of the angels and their participation in the eternal light of God. ${ }^{118}$ Originally, all the angels were created good and enlightened by the light. When some angels turned away from the light, darkness entered their being, because the light was not from them, but from God. In this sense, the angelic darkness constitutes the absence of good and true light. ${ }^{119}$ The depravity of those angels, Augustine observes, is due to the wrong direction of their will. On the basis of their different choices, the angels were divided into two groups living in

\footnotetext{
${ }^{116}$ See Chapter 4.1.

${ }^{117}$ CD 11.19: Non mihi uidetur ab operibus Dei absurda sententia, si, cum lux prima illa facta est, angeli creati intelleguntur, inter sanctos angelos et inmundos fuisse discretum, ubi dictum est: et diuisit Deus inter lucem et tenebras; et uocauit Deus lucem diem et tenebras uocauit noctem...Inter illam uero lucem, quae sancta societas angelorum et inlustratione ueritatis intellegibiliter fulgens, et ei contrarias tenebras, id est malorum angelorum auersorum a luce iustitiae taeterrimas mentes, ipse diuidere potuit, cui etiam futurum non naturae, sed uoluntatis malum occultum aut incertum esse non potuit. Cf. CD 11.9; 11.11; 11.20.

${ }^{118}$ CD 11.9: Cum enim dixit Deus: fiat lux, et facta est lux, si recte in hac luce creatio intellegitur angelorum, profecto facti sunt participes lucis aeternae, quod est ipsa incommutabilis Sapientia Dei.

${ }^{119}$ CD 11.9: Lumen quippe uerum, quod inluminat omnem hominem uenientem in hunc mundum, hoc inluminat et omnem angelum mundum, ut sit lux non in se ipso, sed in Deo; a quo si auertitur angelus, fit inmundus; sicut sunt omnes, qui uocantur inmundi spiritus, nec iam lux in Domino, sed in se ipsis tenebrae, priuati participatione lucis aeternae. Mali enim nulla natura est; sed amissio boni mali nomen accepit. Cf. CD 11.11.
} 
different areas. One group of angels continues to live in the holy city praising God, ${ }^{120}$ whereas the other group has fallen and inhabits the air. ${ }^{121}$ Let us examine Augustine's formulation of the different lives of these groups at the end of the world, focussing on the nature of joy and suffering in their own realm.

\section{The spiritual life of the good angels in the celestial city}

In the beginning of $C D$ 11.13, Augustine specifies two elements as being involved in the concept of blessedness (beatitudo), the fruition of the immutable Good and certain knowledge of the eternality of this enjoyment:

From all this, anyone will now see without difficulty that the blessedness which an intellectual being desires as its proper goal will result from a conjunction of two things: namely, the enjoyment without interruption of the immutable Good which is God; and the certain knowledge, free from all doubt and error, that it will remain in the same enjoyment forever. That the angels of light have such blessedness we piously believe. ${ }^{122}$

Augustine contends that the true happy life of the good angels consists of eternal enjoyment without any disturbances (sine ulla molestia perfruatur). Although all the angels were created to become happy, rational beings, some of them lost this condition because they succumbed to pride. The evil angels did not recognise their fall from the beginning, but the good angels became convinced of their eternal felicity after the fall of others. ${ }^{123}$ Thus, the everlasting fruition without changes

\footnotetext{
${ }^{120}$ CD 11.9: Laudate Eum omnes angeli Eius...Nunc, quoniam de sanctae ciuitatis exortu dicere institui et prius quod ad sanctos angelos adtinet dicendum putaui, quae huius ciuitatis et magna pars est et eo beatior, quod numquam peregrinate.

${ }^{121}$ CD 8.15: Iam uero de loci altitudine, quod daemones in aere, nos autem habitamus in terra. Cf. CD 8.14 and En. Ps. 94.6.

${ }^{122}$ CD 11.13: Quocirca cuiuis iam non difficulter occurrit utroque coniuncto effici beatitudinem, quam recto proposito intellectualis natura desiderat, hoc est, ut et bono incommutabili, quod Deus est, sine ulla molestia perfruatur et in eo se in aeternum esse mansurum nec ulla dubitatione cunctetur nec ullo errore fallatur. Hanc habere angelos lucis pia fide credimus.

${ }^{123}$ Augustine does not believe that bad angels were given foreknowledge of their fall. He speculates that there are two possibilities. One possibility is that angels were originally unequal in the sense that some of them knew their eternal fortune whereas others did not; the other possibility is that angels were equal and good angels came to know their eternal felicity only after the ruin of others. (CD 11.13: Cuius illi alii quia certi non fuerunt (non enim erat eorum aeterna felicitas cuius certi essent, quae finem fuerat habitura), restat, ut aut inpares fuerint, aut, si pares fuerunt, post istorum ruinam illis certa scientia suae sempiternae felicitatis accesserit.) Frederick Van Fleteren thus erroneously states that "the devil was a good angel, happy but with foreknowledge of his own future evil deed and eternal punishment". See Frederick Van Fleteren, "Devil", in Augustine through the Ages: An Encyclopedia, ed. Allan D. Fitzgerald (Grand Rapids, Michigan: Eerdmans, 1999), 268. See also Peter King, "Augustine and Anselm on Angelic Sin", in $A$ Companion to Angels in Medieval Philosophy, ed. Tobias Hoffmann (Leiden: Brill, 2012), 271273.
} 
belongs to the good angels. At the same time, Augustine adds that angels experience joy (gaudium) in their praising God. He poses the following question:

When we say that it is a fault of the angelic creature if it does not cleave to God, we thereby declare more plainly that it belongs to its nature to cleave to God. And who can worthily conceive or express how great a joy it is to cleave to God: to live in Him, to draw wisdom from Him, to rejoice in Him, and to enjoy so great a good without death, without error and without grief? ${ }^{124}$

From the description of this eternal fruition of God, we see that angelic joy is not an emotion known to humans, since it does not involve the fluctuations of the soul that are typical of emotions. Rather, this joy reveals a higher spiritual realm in the divine life.

It is noteworthy that this eternal joy (fruens indeficienter aeternorum iucunditate gaudiorum) will also belong to the human citizens of the Heavenly City. ${ }^{125}$ Augustine claims that redeemed people will fill up the places left by the fallen angels and that they will be equal to good angels (erunt aequales angelis Dei). ${ }^{126}$ Moreover, humans will attain divinity by participating in the divinity of Christ. ${ }^{127}$ Following this reasoning, it is evident that the eternal joy of created beings refers to the spiritual state of both the angelic and the human citizens in Heaven and is manifested in their participation in divinity. Augustine does not provide a clear picture on whether the human beings and the good angels share the same type of divinisation and spiritual life; instead, he is more concerned with the deification of the humans. I shall proceed to this subject in section 5.5.

\section{Suffering as a punishment for demons and their human followers in Hell}

\footnotetext{
${ }^{124}$ CD 12.1: cum uitium creaturae angelicae dicitur, quo non adhaeret Deo, hinc apertissime declaratur, eius naturae ut Deo adhaereat conuenire. Quam porro magna sit laus adhaerere Deo, ut ei uiuat, inde sapiat, illo gaudeat tantoque bono sine morte sine errore sine molestia perfruatur, quis digne cogitare possit aut eloqui?

${ }^{125} C D 22.30$.

${ }^{126}$ CD 22.1: ...qui de mortali progenie merito iusteque damnata tantum populum gratia sua colligit, ut inde suppleat et instauret partem, quae lapsa est angelorum, ac sic illa dilecta et superna ciuitas non fraudetur suorum numero ciuium, quin etiam fortassis et uberiore laetetur. CD 11.13: Veritas quippe in euangelio sanctis fidelibusque promittit, quod erunt aequales angelis Dei. Cf. Matthew 22.30; Luke 20.36.

${ }^{127}$ CD 21.16: ...hominem Christum Iesum, qui factus est particeps mortalitatis nostrae, ut nos participes faceret diuinitatis suae. Sermones nouissimi 6D (=23B).1: Parum tamen fuit Deo nostro promittere nobis in se diuinitatem, nisi et nostram susciperet infirmitatem, tamquam dicens: "Vis nosse quantum te diligam, quam certus esse debeas daturum me tibi diuinum meum?" Cf. CD 14.13; De Trin. 10.5.7; 14.12.15; 2 Peter 1:4.
} 
In his last two books of De civitate Dei, Augustine explores the nature of Hell and the punishment of the damned demons and humans. He poses the question of how the material fire of Hell could burn the wicked spirits as their deserved punishment. Following the scriptural teaching of "their worm shall not die, neither shall their fire be quenched" (Isaiah 66:24; Mark 9:43-48) in Hell, Augustine contemplates whether "fire" and "worm" pertain to the suffering of body:

But some wish to say that these words - that is, "fire" and "worm"-pertain to the punishment of the soul, not the body... Others, however, are in no doubt that both body and soul will suffer pain in that future punishment; and these affirm that the body will be burned with fire, while the soul is to be, as it were, gnawed by the worm of anguish. This is a more appropriate suggestion, for it is clearly absurd to suppose that in that state either body or soul will be free from pain. For my own part, however, I find it easier to say that "fire" and "worm" both pertain to the body than to suppose that neither does. ${ }^{128}$

Responding to the argument that only the soul will suffer, Augustine maintains that the punishment in Hell will involve both the body and the mind by the "lake of fire and brimstone" (stagnum ignis et sulphuris); this fire, he explains, is material (corporeus ignis erit). ${ }^{129}$ The corporeal interpretation of the fire is based on Augustine's speculation on the human state in Hell, which contains both the body and the spirit: "the spirits of men are certainly incorporeal; yet they are now enclosed within the material members of the body, and in the world to come they will again be indissolubly joined to their own bodies". ${ }^{130}$ Consequently, Augustine holds that the pain of burning will not only pertain to the spirits, but also to the bodies of the condemned demons and men.

Responding to the assertion that demons might only have spirits, not bodies, Augustine contends that the material flame could torment the incorporeal soul of demons in an ineffable and wondrous way. ${ }^{131}$ He explains that during this burning, the material fire cannot be animated (inspirentur) and the afflicted object

\footnotetext{
${ }^{128}$ CD 21.9: Utrumque autem horum, ignem scilicet atque uermem, qui uolunt ad animi poenas, non ad corporis pertinere...qui uero poenas et animi et corporis in illo supplicio futuras esse non dubitant, igne uri corpus, animum autem rodi quodam modo uerme maeroris adfirmant. Quod etsi credibilius dicitur, quia utique absurdum est, ibi dolorem aut corporis aut animi defuturum: ego tamen facilius est ut ad corpus dicam utrumque pertinere quam neutrum.

${ }^{129}$ CD 21.10: At uero gehenna illa, quod etiam stagnum ignis et sulphuris dictum est, corporeus ignis erit et cruciabit corpora damnatorum, aut et hominum et daemonum.

${ }^{130}$ CD 21.10: ... si spiritus hominum, etiam ipsi profecto incorporei, et nunc potuerunt includi corporalibus membris et tunc poterunt corporum suorum uinculis insolubiliter alligari.

${ }^{131}$ CD 21.10: Adhaerebunt ergo, si eis nulla sunt corpora, spiritus daemonum, immo spiritus daemones, licet incorporei corporeis ignibus cruciandi.
} 
is only the spirit of the demons; this mode of suffering, he emphasises, is beyond our understanding, though similar to the awareness of the body by the soul. ${ }^{132}$ However, to elaborate on the notion that spirits without bodies can be burned, Augustine describes the suffering of the soul before resurrection. By introducing the story of the rich man who cried, "I am tormented in this flame" (Luke 16:24), Augustine attests that "the flames in which the rich man burned and the drop of water which he sought were incorporeal: they were like the visions of those who sleep or those in a trance, to whom incorporeal things appear in corporeal form". ${ }^{133}$ This example influenced the later doctrine of purgatory that shares a similar interpretation of the flames. ${ }^{134}$ Nevertheless, Augustine emphasises that demons and their followers will be eternally tormented. ${ }^{135}$

It is clear that the suffering in Hell involves both the body and the soul and that it applies even if demons have no bodies. Emotions such as grief, anguish, and torment are not metaphorical in this condition, but present the real misery of deserved eternal condemnation. It is evident that the Heavenly spiritual life involves no fluctuations of the soul that are typical of passions, nor any negative feeling qualities, whereas passions will exist in Hell as sufferings to punish unclean rational beings. Freedom from the human life of passions therefore becomes a vital part of the divine plan of salvation to deliver sinners to a blessed eternal life and to attain divinity in the Kingdom of God. This raises the interesting question that if the punishment of bad angels is due to their desire to be God, but the salvation of humans is aimed at bestowing divinity to them, how will humans come to participate in the divine life? Let us now proceed to examine Augustine's approach to the deification of believers and their emotions.

\subsection{Becoming gods (dii) and the Fruition of God in Heaven}

\footnotetext{
${ }^{132}$ CD 21.10: ...non ut ignes ipsi, quibus adhaerebunt, eorum iunctura inspirentur et animalia fiant, quae constent spiritu et corpore, sed, ut dixi, miris et ineffabilibus modis adhaerendo, accipientes ex ignibus poenam, non dantes ignibus uitam.

${ }^{133}$ CD 21.10: Sic ergo incorporalis et illa flamma qua exarsit et illa guttula quam poposcit, qualia sunt etiam uisa dormientium siue in ecstasi cernentium res incorporales, habentes tamen similitudinem corporum.

${ }^{134}$ Isabel Moreira, Heaven 's Purge: Purgatory in Late Antiquity (Oxford: Oxford University Press, 2010), 34-36. For Augustine's discussions on purgatory, see ench. 18.69; 29.109; Gn. adv. Man. 2.20.30; En. Ps. 37.3; Serm. 159.1; 172.2; CD 21.13; 21.16; 21.24; 21.26.

${ }^{135}$ CD 21.10; 21.23 .
} 
A collection of twenty-six lost sermons by Augustine, the "Dolbeau sermons", were discovered in 1990. ${ }^{136}$ One of them, Sermon 23B (Dolbeau 6), explains Augustine's idea of deification. This sermon, which is dated at the intersection of the year 403-404, ${ }^{137}$ records Augustine's preaching of "becoming gods" to his congregation in Carthage. He begins as follows:

...we look forward to divinity. For God wishes not only to vivify, but also deify us...Still, it was not enough for our God to promise us divinity in himself, unless he also took on our infirmity, as though to say, "Do you want to know how much I love you, how certain you ought to be that I am going to give you my divine reality? I took to myself your mortal reality." We mustn't find it incredible, brothers and sisters, that human beings become gods, that is, that those who were human beings become gods. More incredible still is what has already been bestowed on us, that one who was God should become a human being. And indeed we believe that that has already happened, while we wait for the other thing to happen in the future. The Son of God became a son of man, in order to make sons of men into sons of God. ${ }^{138}$

The theme of attaining divinity and becoming gods is anchored in following the biblical statements: "you may be partakers of the divine nature" (2 Peter 1:4) and "You are gods" (John 10:34; Psalm 82:6). Instead of referring to a human initiative, Augustine contends that salvation is brought by the real benefactor, God, who deifies men. The promise of this deification is through the incarnation of the Son of God. Using the popular exchange (commutatio) formula of the patristic period, Augustine inquires if the Son of God by nature became a man,

\footnotetext{
${ }^{136}$ A manuscript of these sermons was accidentally found by François Dolbeau in the library of Mainz in 1990. The sermons are dated at two periods, the late spring of 397 and the early spring of 404. For more details, see Brown 2000, 443-444; David Vincent Meconi, S.J., “Augustine's Doctrine of Deification", in The Cambridge Companion to Augustine (second edition), ed. David Vincent Meconi and Eleonore Stump (Cambridge: Cambridge University Press, 2014a), 216.

${ }^{137}$ Brown 2000, 443; Meconi 2014a, 216.

${ }^{138}$ Sermones nouissimi 23B. 1: ...exspectamus diuinitatem. Vult enim Deus non solum uiuificare, sed etiam deificare nos...Parum tamen fuit Deo nostro promittere nobis in se diuinitatem, nisi et nostram susciperet infirmitatem, tamquam dicens: "Vis nosse quantum te diligam, quam certus esse debeas daturum me tibi diuinum meum? Accepi mortale tuum." Non nobis uideatur incredibile, fratres, deos fieri homines, id est qui homines erant dii fiant. Incredibilius est quod iam nobis praestitum est, ut qui Deus erat homo fieret. Et illud quidem iam factum credimus, alterum futurum exspectamus. Filius Dei factus est filius hominis, ut filios hominum faceret filios Dei. Cf. Meconi 2014a, 216. The English citations of the sermon 23B in this Chapter are obtained from Hill's translation. See Newly Discovered Sermons III/11, transl. Edmund Hill, ed. John E. Rotelle (Hyde Park, New York: New City Press, 1997).
} 
would men by nature be made the sons of God ${ }^{139}$ He formulates this as "the Son of God became a son of man, in order to make sons of men into sons of God" (Filius Dei factus est filius hominis, ut filios hominum faceret filios Dei) as well as "To make gods those who were men, He was made man who was God" (Deos facturus qui homines erant, homo factus est qui Deus erat). ${ }^{140}$ This involves three related issues. Firstly, what is the ontological relation between the status of God and the gods that humans are becoming? Are they equal in the divine life? Secondly, how are the new sons of God related to Christ, the Son of God? Thirdly, what is the relation between the deified spirit of humans and the Holy Spirit?

\section{The relation between God and the gods}

According to Augustine, the concept of gods in the pagan worship and in the Christian context should be kept separate, since the former refers to gods that are made by humans and the latter refers to the gods whom God makes Himself. ${ }^{141}$ Making idol "gods", Augustine remarks, will hinder believers from becoming gods because they have thus turned away from the true One. ${ }^{142}$ Moreover, they do not truly make gods but merely attach a divine name to materials such as gold or stone. ${ }^{143}$ It is thus an insult for these people to appeal to these idols rather than the

\footnotetext{
${ }^{139}$ See De Trin. 13.9.12: Si enim natura Dei Filius propter filios hominum misericordia factus est hominis filius (hoc est enim, Uerbum caro factum est et habitauit in hominibus), quanto est credibilius natura filios hominis gratia Dei fieri Dei filios et habitare in Deo in quo solo et de quo solo esse possint beati participes immortalitatis eius effecti, propter quod persuadendum Dei Filius particeps nostrae mortalitatis effectus est? Cf. CD 21.15. The exchange formula was popular in the patristic time. Following Irenaeus's statement of "factus est quod sumus nos, uti nos perficeret esse quod et ipse" (Adversus Haereses 5, Praef.), Athanasius states in his De

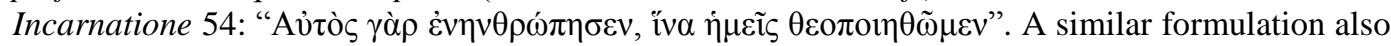
appears in the works of Alexandrian Fathers such as Clement, Origen, and Cyril of Alexandria as well as Cappadocian Fathers such as Basil, Gregory of Nazianzus, and Gregory of Nyssa. See Norman Russell, The Doctrine of Deification in the Greek Patristic Tradition (Oxford: Oxford University Press, 2004), 164-234; Michael J. Christensen and Jeffery A. Wittung (ed.), Partakers of the Divine Nature: The History and Development of Deification in the Christian Traditions (Grand Rapids, Michigan: Baker Academic, 2008), 95-114.

${ }_{140}$ Meconi 2014a, 214; Gerald Bonner, Freedom and Necessity: St. Augustine's Teaching on Divine Power and Human Freedom (Washington, D.C.: Catholic University of America Press, 2007), 62.

${ }^{141}$ For the distinction of the concept of dii in the pagan and Christian understandings, also see Meconi 2014a, 216-217.

${ }^{142}$ Sermones nouissimi 23B. 3: Vos adoratis Deum, qui uos facit deos; illi autem adorant deos, quos faciendo et adorando perdunt ut ipsi dii fiant, faciendo falsos cadunt a uero.

${ }_{143}$ Sermones nouissimi 23B. 3: Cui diuinum nomen imponis, uocabitur deus; erit autem uel lignum uel lapis uel aurum, uel quidquid aliud est.
} 
Highest being, as it reduces a human's inner self (homo interior) to lower unintelligent things, such as stones. "How can human beings become like dumb idols?"144 Augustine answers:

Well, according to this likeness which we are suggesting, if the inner self becomes somehow or other insensitive, stupid, he becomes in a certain manner like an idol, and having ruined in himself the image of the one by whom he was made, he wishes to take on the image of the one which he has made. ${ }^{145}$

Augustine notes further that when one adores these numb and lifeless idols, they are actually admiring demons, since the pagan worshipers would claim that they do not appeal to the outward forms, but to the spirit of their gods. ${ }^{146}$ Augustine reminds hearers to pay attention to certain biblical texts such as "All the gods of the nations are demons, while it is the Lord who made the heavens" (Psalm 96:5) and "What the nations sacrifice, they sacrifice to demons and not to God. I do not wish you to become the associates of demons" (1 Cor. 10:20). ${ }^{147}$ These "gods", Augustine warns, are not actually idols, but demons who will induce believers into the eternal fire. ${ }^{148}$ These unclean spirits deceive humans to worship them as gods in order to block their approach toward the Blessed City. ${ }^{149}$ The ulterior motives of these demons are their desire to be gods and their begrudging humans' eternal felicity. The demons incite God's wrath and damnation, and for them, God is a source of terror. ${ }^{150}$

\footnotetext{
${ }^{144}$ Sermones nouissimi 23B. 5: Vnde similes possunt fieri homines mutis simulacris?

145 Sermones nouissimi 23B. 5: Sed secundum istam similitudinem quam commendamus: si fiat insensatus quodammodo homo interior, fit ad quendam modum similis simulacro et, perdita in se imagine eius a quo factus est, eius quem fecit uult capere imaginem.

146 Sermones nouissimi 23B. 8.

147 Sermones nouissimi 23B. 9: "Omnes dii gentium daemonia, Dominus autem caelos fecit”... "Quae immolant gentes, daemoniis immolant et non Deo. Nolo uos socios fieri daemoniorum". Cf. $C D 1.29$.

148 Sermones nouissimi 23B. 9: Non ait: "Nolo uos fieri socios idolorum"...Adtendite enim, fratres, quid dicam. Socius esse idoli, etsi uelis, non potes; socius autem daemoniorum, si uelis, eris, si nolis, non eris. Omnibus enim sociis diaboli et angelorum eius in fine dicetur: Ite in ignem aeternum, qui paratus est diabolo et angelis eius.

${ }^{149}$ CD 2.29:...isti daemones, quos adhuc deos putas, omni generi hominum sedes inuident sempiternas...patere asseri libertatem tuam aduersus inmundos spiritus, qui tuis ceruicibus inposuerant sacrandam sibi et celebrandam ignominiam suam.

${ }^{150}$ En. Ps. 49.2: ...et dii qui non sunt dii, quibus ille Deus deorum terribilis est. Dicit enim alius psalmus: Terribilis est super omnes deos. Et quasi quaereres: quos deos? Quoniam omnes dii gentium daemonia. Diis gentium, daemoniis terribilis. For Augustine's view of demons, see Frederick Van Fleteren, "Demons", in Augustine through the Ages: An Encyclopedia, ed. Allan D. Fitzgerald (Grand Rapids, Michigan: Eerdmans, 1999), 266-268.
} 
Augustine explains that while God hates the self-deifying spirits, He loves those whom He deifies. ${ }^{151}$ This account provides a vivid picture for discerning the identities of gods (dii) and God (Deus). In Augustine's opinion, the dividing line between the Creator and the creation should not be blurred. He emphasises that the deified gods are "not gods by nature but by adoption, by grace" (non natura deorum, sed adoptione, sed gratia), ${ }^{152}$ "We are like God, but not equal to Him" (nos enim similes, non aequales) ${ }^{153}$ and "God called human beings 'gods' in the sense that they were deified by his grace, not because they were born of his own substance"154. "By adoption" and "by grace" refer to the difference between the nature of dii and Deus, even though humans will receive immortality and share divinity in the inner life of God. ${ }^{155}$ Augustine regards the deification of humans as a process from the unlikeness to the likeness of God. This process is described as a movement toward the perfect form, although the destination is the perfect image of God rather than equality to Him. ${ }^{156}$ Then humans as the image of God will be fully renewed and included in the relation of the "full likeness" in the vision of "face to face". Augustine states that "the full likeness to God will then be realised in this image of God when it shall receive the full vision of Him". 157

Thus, desiring to become god in a sinful way and becoming gods through grace and participation are two distinct modes of relation between God and the gods in which Augustine carefully draws the line between the Creator and the deified gods. Augustine cautions against any desire to be equal to God, as he considers it to be the wrong approach to deification; instead, to be "like God" by

\footnotetext{
${ }^{151}$ En. Ps. 49.2: diis a se factis, filiis amabilis.

152 Sermones nouissimi 23B. 2.

153 En. Ps. 49.2.

${ }^{154}$ En. Ps. 49.2: ...quia homines dixit deos, ex gratia sua deificatos, non de substantia sua natos.

155 Augustine maintains that the Heavenly human citizens will attain the divine life by grace, but their nature cannot be made equal to the Creator, as explained in De Trin. 15.23.43: "And when they shall be cured of every infirmity and shall be mutually equal, even then that thing, which through grace shall not be changed, will not be made equal to the thing that is unchangeable in its nature, because the creature is not equal to the Creator, and will undergo a change when it shall be cured of every infirmity". Cf. De Trin. 13.9.12.

${ }^{156}$ De Trin. 15.16.26: ...formata erit creatura quae formabilis fuit ut nihil iam desit eius formae ad quam peruenire deberet; sed tamen coaequanda non erit illi simplicitati ubi non formabile aliquid formatum uel reformatum est sed forma.

${ }^{157}$ De Trin. 14.18.24: Hinc apparet tunc in ista imagine Dei fieri eius plenam similitudinem quando eius plenam perceperit uisionem. Cf. De Trin. 15.11.21.
} 
participation is what God wishes in His plan of creation. ${ }^{158}$ Augustine explains this further in his interpretation of Psalm 82:1:

Our God, the true God, the one God, has stood up in the synagogue of gods, many of them of course, and gods not by nature but by adoption, by grace. There is a great difference between God who exists, God who is always God, true God, not only God but also deifying God; that is, if I may so put it, god-making God, God not made making gods, and gods who are made, but not by a craftsman. ${ }^{159}$

\section{The relation of the sons of God to the Son of God}

A fundamental issue in deification is the question of how the new sons of God are related to the Son of God. Following the exchange formula, Augustine argues in one of his sermons that "because he is also us...So we too are him" (Serm. 133.8: quia et nos ipse est...ergo et nos ipse). The idea of "we are Christ" (nos Christus essemus) occurs several times in his sermons, in which he conveys the relation between Christ and us through the notion of the whole Christ (totus Christus). ${ }^{160}$ Augustine states in his Enarrationes in Psalmos:

He is like a spotless lamb who redeemed us by his own spilt blood, uniting us into one body with himself and making us his members, so that in him we too are Christ...we are the body of Christ, being all anointed. In him all of us belong to Christ, but we are Christ too, because in some sense the whole Christ is Head and body. This anointing will make us spiritually perfect in the life which is promised to us. ${ }^{161}$

Christ's dwelling in us to make us live in Him and thus to attain spiritual perfection is the end of the salvation in Christ. The analogy of the head and body reveals the organic relationship between the Son of God and His members in the unity of Christ. Augustine does not use the "Christ-like" terminology here, but he

158 CD 22.30: Eritus sicut dii et recedentes a uero Deo, quo faciente dii essemus eius participatione, non desertione.

${ }^{159}$ Sermones nouissimi 23B. 2: Deus noster, Deus uerus, Deus unus stetit in synagoga deorum, utique multorum, non natura deorum, sed adoptione, sed gratia. Multum interest inter Deum exsistentem, Deum semper Deum, uerum Deum, non solum Deum, sed etiam deificatorem Deum, hoc est, ut ita dicam, deificum Deum, Deum non factum deos facientem, et deos qui fiunt, sed non a fabro.

${ }^{160}$ Meconi explains the concept of the totus Christus in Augustine's theory of deification, which, he argues, conveys Augustine's idea of union with Christ: "As 'head', Christ makes his body his very own, thereby forging union of mutual identification so real that therein, he becomes us and we become him". Meconi 2014a, 223-224.

${ }^{161}$ En. Ps. 26 (2.2):...tamquam agnus immaculatus fuso sanguine suo redimens nos, concorporans nos sibi, faciens nos membra sua, ut in illo et nos christus essemus...inde autem apparet Christi corpus nos esse, quia omnes ungimur; et omnes in illo et Christi et Christus sumus, quia quodammodo totus Christus caput et corpus est. Unctio ista perficiet nos spiritaliter in illa uita, quae nobis promittitur. Cf. Meconi 2014a, 223-224. 
says, "we are Christ". This saying is applied to present-day life, referring to the community of believers, but it also pertains to the future divinised condition. As the body of Christ, the members will be gradually renewed and attain the final consummation in Him. Augustine asserts that in this sense, the title "Christ" refers to the unity of the head and body being anointed together. ${ }^{162}$

This does not, however, imply that the adopted sons are equal to the Son of God because Augustine states: "we are not like God in the same way as the Son is, for He is of one nature with the Father from whom He is born; we are like God, but not equal to Him; the only Son is like Him because equal to Him". ${ }^{163}$ Augustine employs the doctrine of the imago Dei in arguing that we are approaching the full image of God the Son and the full likeness of God (fieri Eius plenam similitudinem) at the moment of seeing God face-to-face. ${ }^{164} \mathrm{He}$ states, "the likeness of the image that was made approaches, insofar as it can, to the likeness of the image that was begotten, whereby God the Son is proclaimed as substantially like the Father in all things...when the image, therefore, has been renewed by this transformation, and so brought to perfection, then we shall be like to God". ${ }^{165}$ This likeness in the perfect state, Augustine explains, is the same image of Him, as stated in 2 Corinthians 3:18: "we might be transformed into the same image from glory to glory, as through the Spirit of the Lord". ${ }^{166}$ The difference between the likeness of the created image in humans and the likeness of the begotten image in Christ reveals the relation between the adopted sons and the

\footnotetext{
${ }^{162}$ En. Ps. 26 (2.2): utroque munere unus Christus, et ideo Christus a Chrismate. Non solum autem caput nostrum unctum est, sed et corpus eius nos ipsi.

${ }^{163}$ En. Ps. 49.2: Non enim ita similes ut ille, qui hoc est quod ille a quo genitus est; nos enim similes, non aequales; ille quia aequalis, ideo similis.

${ }^{164}$ De Trin. 14.18.24: Hinc apparet tunc in ista imagine Dei fieri Eius plenam similitudinem quando Eius plenam perceperit uisionem, quamquam possit hoc a Iohanne Apostolo etiam de immortalitate corporis dictum uideri. As far as the immortality of the body is concerned, humans may become an image of the Son of God. See De Trin. 14.18.24: ...quamquam possit hoc a Iohanne Apostolo etiam de immortalitate corporis dictum uideri. Et in hac quippe similes erimus Deo sed tantummodo Filio quia solus in Trinitate corpus accepit in quo mortuus resurrexit atque id ad superna peruexit.

${ }^{165}$ De Trin. 15.11.20-21: Sic accedit quantum potest ista similitudo imaginis factae ad illam similitudinem imaginis natae qua Deus Filius Patri per omnia substantialiter similis praedicatur... Cum ergo hac transformatione ad perfectum fuerit haec imago renouata similes Deo erimus. In this translation by McKenna and Matthews, I have made a slight change by replacing the word "born" with "begotten".

${ }^{166}$ De Trin. 15.8.14; 15.11.20: ...in eandem imaginem transformemur de gloria in gloriam tamquam a Domini Spiritu...
} 
Son of God. We will attain the likeness of God as an image of Him when this image will be perfected in Heaven, ${ }^{167}$ but we cannot be equal to Him in substance.

\section{Eternal fruition of God in Heaven being filled with the Holy Spirit}

When interpreting the deification of Christians in Christ, Augustine concludes that they share one Spirit (unus Spiritus) with Him, since He breathed the Spirit on them (John 20:22) ${ }^{168}$ As love, the Spirit unites not only the Father and the Son, but also God and humans as well as the community of believers. ${ }^{169}$ Thus, by the indwelling of the Spirit, humans will attain spiritual perfection in Heaven. Augustine discusses the indwelling of the Holy Spirit in his Tractates on the First Letter of John (ca. 406-407):

..."If we love one another, God abides in us and his love will be perfected in us." Begin to love; you will be perfected. Have you begun to love? God has begun to dwell in you; love him who has begun to dwell in you that by indwelling more perfectly he may make you perfected...Ask your heart; if it is filled with love, you have the Spirit of God. How do we come to know that you come to know from that that the Spirit of God dwells in you? Ask Paul the Apostle: "Because the love of God has been poured forth in our hearts by the Holy Spirit who has been given to us." ${ }^{\text {"170 [transl. Rettig] }}$

The basis for deified gods to attain the divine spiritual life is being filled by the Spirit. As the image of the Son of God, all adopted children will receive the same Spirit in Him, by which the old corrupted soul will be healed and perfected with no more fluctuations in Heaven. The fruition of God will be the fulfilment of the salvation of humans from experiencing evil emotions. At this moment, the deified gods will participate in the inner divine life by the love bond of the Holy Spirit, which is the perfect union of divine persons and deified human beings. While Augustine comments on the perfect union in Heaven, he also emphasises the

${ }^{167}$ De Trin. 14.18.24: Hinc apparet tunc in ista imagine Dei fieri Eius plenam similitudinem quando Eius plenam perceperit uisionem.

${ }^{168}$ De Trin. 6.5.7: Nos autem ex ipso et per ipsum et in ipso beati quia ipsius munere inter nos unum; cum illo autem unus Spiritus quia agglutinatur anima nostra post eum. Ep. Io. 8.12: In hoc cognoscimus quia in ipso manemus et ipse in nobis, quia de Spiritu suo dedit nobis... Quia hoc ipse Iohannes dixit: quia de Spiritu suo dedit nobis.

${ }^{169}$ See Meconi 2014a, 221-222.

${ }^{170}$ Ep. Io. 8.12: Si diligamus inuicem, Deus in nobis manebit et dilectio eius erit perfecta in nobis. Incipe diligere; perficieris. Coepisti diligere? coepit in te Deus habitare. Ama eum qui in te coepit habitare ut perfectius habitando faciat te perfectum...interroga uiscera tua. Si plena sunt caritate, habes spiritum dei. Unde cognoscimus quia inde cognoscis habitare in te Spiritum Dei? Paulum interroga apostolum: Quoniam caritas Dei diffusa est in cordibus nostris per Spiritum Sanctum qui datus est nobis. Cf. Meconi 2014a, 222. 
degrees of indwelling of the Spirit and new love in the believers in the present life. ${ }^{171}$

Augustine highlights the difference in how the Spirit exists in the Trinity and in the deified gods. In the Trinity, the Spirit is equal to the Father and the Son in essence as well as the unity of these three persons together. ${ }^{172}$ Furthermore, their communion is not through participation, but is essentially consubstantial and coeternal. ${ }^{173}$ The Holy Spirit, as the love that binds the Father and the Son together, is the same substance and the uncreated God Himself. Yet the union of the deified gods with the Trinity in the divine spiritual life is through participation and adherence by grace, not through their own essence. Augustine compares these two distinct relations: “...in Him they [the Trinitarian persons] preserve the unity of spirit through the bond of peace, not by a participation but by their own essence, not by the gift of anyone superior to themselves but by their own gift. And we are commanded by grace to imitate the unity, both in our relations with God as well as among ourselves". ${ }^{174}$ The immortality and the fruition of the divine "emotional" life of believers are due to their adherence to God and their being filled with the Spirit, not by a substitution of human nature with the ousia of God and thus being equal to the Holy Spirit. The deified gods are creatures who undergo a transformation rather than immutable beings with no beginning or end. Therefore, the fruition of God will be a perfect Spirit-filled state and an attainment of divine spiritual reality.

The theory of the divine adoption and the approach to the full likeness of God is evidence that Augustine's vision of becoming gods is based on the doctrine of the imago Dei, with three important points. Firstly, those whom God deifies will be the sons of God. Their becoming gods occurs through participation

\footnotetext{
${ }^{171}$ For progress, see De Trin. 14.17.23: In agnitione igitur Dei iustitiaque et sanctitate ueritatis qui de die in diem proficiendo renouatur transfert amorem a temporalibus ad aeterna, a uisibilibus ad intellegibilia, a carnalibus ad spiritalia, atque ab istis cupiditatem frenare atque minuere illisque se caritate alligare diligenter insistit. Tantum autem facit quantum diuinitus adiuuatur Dei quippe sententia est: Sine me nihil potestis facere.

${ }^{172}$ De Trin. 6.8: Cum itaque tantus est solus Pater uel solus Filius uel solus Spiritus Sanctus quantus est simul Pater et Filius et Spiritus Sanctus, nullo modo triplex dicendus est.

${ }^{173}$ De Trin. 6.5.7: Spiritus ergo sanctus commune aliquid est Patris et Filii, quidquid illud est, aut ipsa communio consubstantialis et coaeterna.

${ }^{174}$ De Trin. 6.5.7: ... sint que non participatione sed essentia sua neque dono superioris alicuius sed suo proprio seruantes unitatem spiritus in uinculo pacis. Quod imitari per gratiam et ad Deum et ad nos ipsos iubemur.
} 
by grace instead of the self-deification of the fallen spirits. Secondly, the final divinised state will be the perfect likeness of God as the perfection of the original created imago Dei. Therefore, the ontological gulf between dii and Deus will remain clear. Thirdly, human emotions will be transformed into spiritual perfection through the bond of the Holy Spirit. The participation in the triune spiritual life is the emotional orientation of ontologically dependent imago Dei. Augustine's notion of becoming the full likeness of God has often been criticised by Orthodox theologians. Even though the newly discovered sermons of Augustine mentioned above were not available to the critics, it is useful to examine this discussion.

\subsection{Evaluation of Augustine's Doctrine on the Deification of Emotions}

Some Orthodox theologians ${ }^{175}$ have accused Augustine of being blind to the Greek patristic deification theory, as his major concern is the fulfilment of humanity rather than the genuine deificatory transformation of human beings. This is claimed to have led to the doctrinal breach between the West and the East. Some main evaluations in this approach are as follows.

Myrrha Lot-Borodine was a pioneer in addressing the Greek patristic theories of deification in the twentieth century. ${ }^{176}$ In La déification de l'homme, she argues that Augustine does not formulate a proper doctrine of deification. Commenting on Augustine's approach, Lot-Borodine remarks that it is "toward beatitude, not deification", since his orientation lies in the fulfilment of human nature and spirituality, without involving the thought of the genuine

\footnotetext{
${ }^{175}$ Important figures in the patristic revival of the last century were Orthodoxy theologians such as Myrrha Lot-Borodine, Vladimir Lossky, and Georges Florovsky. They were protagonists in the neo-Palamite school and tried to revive the spiritual theology and deification doctrine of the Greek and Orthodoxy Fathers. For the background of this revival, see Andrew Louth, "The Patristic Revival and its Protagonists", in The Cambridge Companion to Orthodox Christian Theology, ed., Mary B. Cunningham and Elizabeth Theokritoff (Cambridge: Cambridge University Press, 2008), 188-202; Jeffrey D. Finch, "Neo-Palamism, Divinizing Grace, and the Breach between East and West", in Partakers of the Divine Nature: The History and Development of Deification in the Christian Traditions, ed., Michael J. Christensen and Jeffery A. Wittung (Grand Rapids, Michigan: Baker Academic, 2007), 233-249.

${ }^{176}$ For an introduction of Lot-Borodine's role in the modern studies of the patristic doctrine of deification, see Heleen E. Zorgdrager, "A Practice of Love Myrrha Lot-Borodine (1882-1954) and the Modern Revival of the Doctrine of Deification", in Journal of Eastern Christian Studies 64 (2012), 288-290.
} 
transformative divinisation of elevating human beings to the nature of God. ${ }^{177}$ Lot-Borodine notes that Augustine adopts an apophatic reading to explore the essence of the Trinity. While carefully discerning the ontological demarcation between the Creator and the created, Augustine is unable to conceive of the "compénétration" (or "consubstantialité") as a manner for humans to participate in divine nature. ${ }^{178}$ For Lot-Borodine, the statement of "partaker in the divine nature" in 2 Peter 1:4 refers to becoming divine, but this deifying relationship with God does not undo the ontological gulf between the created and the uncreated in terms of essence; instead, it refers to the interpenetration between humanity and uncreated divine energies. This means that a distinction needs to be drawn between these two concepts, the essence and the energies of God. ${ }^{179}$ LotBorodine maintains that in the spirit of Palamite theology, it is impossible to access the essence (ousia) of God, whereas the uncreated energies ("énergies") are accessible and communicable. ${ }^{180}$ This is due to the transcendence and incomprehensibility of God which is addressed in apophatic theology ("théognosie apophatique"). ${ }^{181}$ Thus, deification is referred to as a communion with the energies and light of God ("Voir la lumière, c'est voir Dieu") rather than with the ousia of God. ${ }^{182}$ According to Lot-Borodine, the Greek theological tradition makes the crucial distinction between the divine essence and its operations within the nature of the deity, but this is not found in the Western

\footnotetext{
${ }^{177}$ Myrrha Lot-Borodine, La déification de l'homme selon la doctrine des pères grecs (Paris: Editions du Cerf, 1970), 39-40. Lot-Borodine's works are in French; for the English interpretation of her works, see Mary N. R. Marrocco, Participation in the Divine Life in St. Augustine's De Trinitate and Selected Contemporary Homiletic Discourses (Toronto: Ph.D. Dissertation, 2000), 15-16; Paul M. Collins, Partaking in Divine Nature: Deification and Communion (London: Bloomsbury T\&T Clark, 2010), 69-73; Zorgdrager 2012, 287-307.

${ }^{178}$ Lot-Borodine 1970, 37 and 40. Cf. Marrocco 2000, 15-16; Zorgdrager 2012, 296.

${ }^{179}$ Lot-Borodine 1970, 29; Zorgdrager 2012, 295 and n. 30.

${ }^{180}$ Myrrha Lot-Borodine, "La doctrine de la déification dans l'Église Grecque jusqu'au XI siècle", in Revue de l'histoire des religions (Paris: Librairie Ernest Leroux, 1933), 42-43; Cf. LotBorodine 1970, 35-36; Marrocco 2000, 16 and n. 26. For Palamas's theory and the tradition of Orthodox theology, see Augustine Casiday, "Church Fathers and the Shaping of Orthodox theology", in The Cambridge Companion to Orthodox Christian Theology, ed., Mary B. Cunningham and Elizabeth Theokritoff (Cambridge: Cambridge University Press, 2008), 167187. For Palamism in Lot-Borodine, see Louth 2008, 192-193.

${ }^{181}$ Zorgdrager notes that Lot-Borodine's use of "théognosie apophatique" is taken from Clement of Alexandria. See Zorgdrager 2012, 295.

${ }^{182}$ Lot-Borodine 1970, 169; Zorgdrager 2012, 305.
} 
thought influenced by Augustine. ${ }^{183}$ In fact, a gulf between East and West on the matter of divinisation is evident in the absence of the doctrine of interpenetration and the distinction between essence and energies in the Latin theology (especially in Augustine). ${ }^{184}$

This negative attitude toward Augustine and the Latin doctrine of deification is repeated by other Neo-Palamite authors, such as Vladimir Lossky, Georges Florovsky, and John Meyendorff, who draw on the spiritual theology of Maximus Confessor and the mystical theology of Simeon "the New Theologian" and Palamas. These authors emphasise that God is unknown (apophatic) in His essence, but is recognised in His energies, and that salvation is a deificatory transformation through a participation in divine energies. Lossky asserts that while Augustine also appeals to the path of negations in speaking about God, the issue is that the apophatic approach is unable to reach an infinite being. ${ }^{185}$ Explaining Augustine's description of the fleeting contact of the soul with eternal wisdom (or "ecstacy of Ostia") in Conf. 9.4.10, Lossky remarks, "the whole question of St. Augustine's mysticism depends on the interpretation of this 'contact'. But he does not define its nature". ${ }^{186}$ According Lossky, failing to distinguish between the essence and the energies of God makes it impossible to understand the meaning of deification; ${ }^{187}$ it appears paradoxical that while God is ineffable and inaccessible, the divinisation implies an access to the nature of God. Thus, the deity is incommunicable and yet communicable and God is "both totally inaccessible and at the same time accessible". ${ }^{188}$ Although God's essence is

\footnotetext{
${ }^{183}$ Lot-Borodine 1970, 36; Cf. Finch 2007, 240-241. Zorgdrager notes that Lot-Borodine's position is primarily influenced by Gregory of Palamas. In addition, she is also inspired by Basil, Gregory of Nyssa, Denys the Areopagite, and Maximus Confessor who made the distinction between the divine essence and energies with various expressions. See Zorgdrager 2012, 295; 305. ${ }^{184}$ Lot-Borodine 1970, 39-40. Zorgdrager explains that "Lot-Borodine comments that at this point [Augustine's fails to understand the vision of 'mutual permeation of the divine and human nature'] the bridges between East and West were already broken down, long before the official schism". Zorgdrager 2012, 296; Cf. Marrocco 2000, 15-16; Finch 2007, 240; Meconi 2014, 209; Collins 2010, 69 .

${ }^{185}$ Vladimir Lossky, "Elements of 'Negative Theology' in the Thought of St. Augustine", in St. Vladimir's Theological Quarterly 21 (1977), 73-74.

${ }^{186}$ Lossky 1977, 74.

187 Vladimir Lossky, The Mystical Theology of the Eastern Church (London: James Clarke, 1957), 69-71; Vladimir Kharlamov, "Basil of Caesarea and the Cappadocians on the Distinction between Essence and Energies in God and Its Relevance to the Deification Theme", in Theosis: Deification in Christian Theology (Volume II), ed., Vladimir Kharlamov (London: James Clarke, 2012), 102.

${ }^{188}$ Lossky 1957, 69-70.
} 
transcendent and inaccessible, His grace of energies is accessible and communicable, and this makes deification possible. Lossky explains this theological doctrine in his Mystical Theology:

The divine nature must be said to be at the same time both exclusive of, and, in some sense, open to participation. We attain to participation in the divine nature, and yet at the same time it remains totally inaccessible. We need to affirm both at the same time and to preserve the antinomy as a criterion of right devotion...even in the very least degree, we should not at the moment be what we are, we should be God by nature...God, therefore, is and remains inaccessible to us in His essence...This distinction is that between the essence of God, or His nature, properly co-called, which is inaccessible, unknowable and incommunicable; and the energies or divine operations, forces proper to and inseparable from God's essence, in which He goes forth from Himself, manifests, communications, and gives Himself. ${ }^{189}$

Deification, for Lossky, refers to a union with God's essence through its uncreated operations or energies so that the deified realisation of attaining the deity is real. ${ }^{190}$ In this sense, Lossky complains that Augustine's static interpretation of the divine nature as immutable, indivisible, incomprehensible, and inaccessible can only block the human approach to the inner life of the Godhead and turn the divine promise of participation in divine nature into an illusion. ${ }^{191}$

In line with the neo-Palamite school, Christos Yannaras and Philip Sherrard claim that the inability to recognise the essence-energy distinction and their homogeneous nature in divinity is a serious shortcoming in Augustine and the Latin theology. Yannaras warns that if one does not make a distinction between essence and energy in divinity, but mistakenly regards "energy" as "heteroessential", that is, a created result of the divine cause, this implies that "the theosis of man, his participation in the divine life, becomes impossible". ${ }^{192}$ Yannaras further claims that the Western doctrine of deification is misled by the

\footnotetext{
${ }^{189}$ Lossky 1957, 69-70. Lossky's understanding of divinised participation in the nature of God is also explained by Jeffrey D. Finch in his "Neo-Palamism, Divinizing Grace, and the Breach between East and West", see Finch 2007, 234 and 245 (n. 5).

${ }^{190}$ By referring to St. Palamas, Lossky states: "The divine and deifying illumination and grace is not the essence but the energy of God', a 'divine power and energy common to the nature in three'. Thus, according to St. Gregory Palamas, 'to say that the divine nature is communicable not in itself but through its energy, is to remain within the bounds of right devotion"'. Lossky 1957, 70.

${ }^{191}$ Lossky 1957, 70, 95 and 96. Cf. Finch 2007, 236-237.

${ }^{192}$ Christos Yannaras, "The Distinction between Essence and Energies and Its Importance for Theology”, in St. Vladimir's Theological Quarterly 19 (1975), 242-243; Cf. Finch 2007, 234.
} 
logic of "whatever is not essence does not belong to God", which excludes the divinising grace of energies and powers of God from uncreated nature. ${ }^{193}$ This weakness in the Latin theology, influenced by Augustine, entails its break with Orthodox theology. ${ }^{194}$ Philip Sherrard concurs that Augustine's inability to conceive of possessing the nature of God by the uncreated grace of energies is due to his vision of God as an "absolute simplicity and indivisibility". ${ }^{195}$ Sherrard maintains that Augustine's ideal state of a soul in union with the essence of God is not "the deiform vov $\zeta$ ", for a human soul cannot attain the transcendent divine essence. ${ }^{196}$ Sherrard notes that the failure of Augustine's theory to admit the distinction of the essence and the uncreated energies, causes the soul to "remain separate from it [the Godhead], and outside it, and in no way becomes its own nature". 197 Thus, Augustine's proposal of deification is to be "untransformed through participation in the spiritual knowledge of the intellect", which is a matter of human beatitude rather than the deified realisation of attaining the deity. ${ }^{198}$ Sherrard levels a more critical viewpoint when he argues that Augustine's approach is "tantamount to condemning man to a state of insurmountable ignorance concerning his life and destiny, and hence open the door to all manner of doubts". 199

Jaroslav Pelikan supports a more inclusive attitude toward the different interpretations of deification in Augustinian and Orthodoxy theology in his work

193 Yannaras 1975, 242-243; Cf. Finch 2007, 234.

194 "The problem of the distinction between essence and energies determined definitely and finally the differentiation of the Latin West from the Orthodox East". Yannaras 1975, 242. Vladimir Kharlamov explains that "The problem, according to Yannaras, is even worse than that. The inability of the West, mislead by Augustine (and subsequently by Scholasticism), to recognize this distinction helped to plant heresy, atheism, and rationalism in the West”. Kharlamov 2012, 103.

195 "For this deification proceeds from God and from man's direct intuition of His transfiguring light. In that light, man knows, in an absolute sense, both his own divine cause, and the causal energies of all created things. If, therefore, either the immanence of God in man, or the possession by man of such a faculty as that indicated, is denied, then the realization in question will be regarded as impossible...Yet precisely the possibility of this realization was, if not denied, at least obscured by the main conceptions of much Latin theology, particularly in its Augustinian and Thomist forms...[For Augustine] The Being of God is therefore of an absolute simplicity and indivisibility, and any qualities or properties attributed to God, such as those St. Augustine calls the 'principal forms, or stable and immutable essences of things', and the Fathers His uncreated powers and energies, must be indistinguishably identified with His Being...But here precisely one comes up against a difficulty". Philip Sherrard, The Greek East and the Latin West: A Study in the Christian Tradition (London: Oxford University Press, 1959), 141-143.

196 Sherrard 1959, 143.

197 Sherrard 1959, 143-144.

198 Sherrard 1959, 152.

${ }^{199}$ Sherrard 1959, 155. 
The Spirit of Eastern Christendom. Pelikan discusses the doctrinal background of the theologians in the setting of the theosis in the Byzantine Orthodoxy. ${ }^{200} \mathrm{He}$ notes that a divergence indeed occurs between their understanding of deification and Augustinian interpretations, but it rather reflects different definitions of Christianity. ${ }^{201}$ An attractive point of the Byzantine account of deification is becoming God through a mystical union. For instance, Simeon describes a vision of God who tells him: "Yes, I am God, the one who became man for your sake. And behold, I have created you, as you see, and I shall make you God" (Ethical Orations 5). ${ }^{202}$ In interpreting how to participate in divine nature, Simeon and Palamas employ three themes of the Eastern spiritual theology, "theology as apophaticism, revelation as light, and salvation as deification". ${ }^{203}$ These three aspects are interrelated: according to the apophatic theology, God is transcendent and inaccessible; the path toward the vision of God is found through participating in the shining of the true light which is God Himself; ${ }^{204}$ and the divine in deification is not symbolic but the reality of salvation. Following these formulations, Pelikan concludes that Palamas wisely interprets the deification: "the deifying gift of the Spirit is not the superessential ousia of God, but the deifying activity of the superessential ousia of God". ${ }^{205}$ This distinction between ousia and actions in the Godhead forms the basic characteristic in the Eastern approach of deifying salvation that leads to the break with Augustinian and Western doctrines. ${ }^{206}$

\footnotetext{
${ }^{200}$ See Jaroslav Pelikan, "The Last Flowering of Byzantine Orthodoxy", in The Spirit of Eastern Christendom (600-1700) (Chicago and London: The University of Chicago Press, 1974), 252298.

201 "The divergences between the Eastern and Augustinian definitions of Christianity were expressed in connection with this doctrine of deification”. Pelikan 1974, 260.

${ }^{202}$ Pelikan 1974, 260. Pelikan also exemplifies two other cases in Ethical Orations 1.10, where

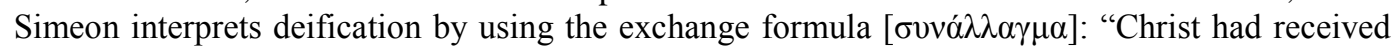
his flesh from his mother and had conferred divinity on her in return; on the other hand, he did not receive flesh from the saints but conferred upon them his own deified flesh instead". Ibid., 260.

${ }^{203}$ Pelikan 1974, 264.

204 "The way to acquire the vision of God was through acts of thanksgiving and love... There was no other way for anyone to come to know God except by the vision of this true light. The supreme manifestation of the light on earth was the transfiguration of Christ, when 'his face shone like the sun, and his garments became white as light.' What shone here was 'the light of deity' rather than a sign or symbol". Pelikan 1974, 260-261.

${ }^{205}$ Gregory Palamas, Triads 3.1.34. Pelikan 1974, 267.

${ }^{206}$ Pelikan 1974, 269-280.
} 
Let us take a look at some formulations of "becoming God" in the Eastern Church Fathers that the Neo-Palamite theologians rely on. Irenaeus and Athanasius are two precursors who use this formula. Irenaeus declares that the Word of God "became what we are in order to make us what he is" (factus est quod sumus nos, uti nos perficeret esse quod et ipse). ${ }^{207}$ Athanasius states that

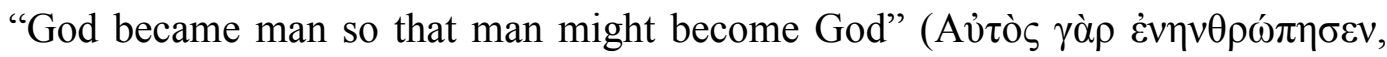

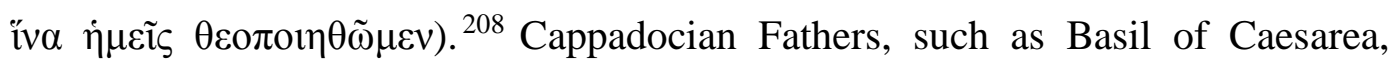
write that when the Holy Spirit dwells in the soul of the Heavenly citizens, they will "become like God, and, the highest of all desires, becoming God". 209 Maximus the Confessor similarly states that the incarnation "makes God a man by the deification of the man, and man a God by the humanization of God" and "Man becomes God to the extent that God becomes man, for man is elevated by the divine ascension to the same degree that God is overcome by His love of men in descending without change to the last extremities of our nature". ${ }^{210}$ The issue at point concerns the sense and manner in which humans will be deified.

To avoid the full identity between God and man, Maximus emphasises that "All that God is, except for an identity in ousia, one becomes when one is deified by grace". ${ }^{211}$ In line with Maximus's teaching, the Palamite essence-energy

${ }^{207}$ John Kaufman offers the English translation of Irenaeus's Latin text (Adversus Haereses 5, Praef.) as follows: "the only sure and true Teacher, the Word of God, Jesus Christ our lord, who because of his immeasurable love became what we are in order to make us what he is". Kaufman presents a systematic survey on the deification ideas in Irenaeus, attesting that the Latin term perficere (to complete, perfect) in the above quotation reveals that man will become the Son who is "God". See John Kaufman, Becoming Divine, Becoming Human: Deification Themes in Irenaeus of Lyons (Oslo, MF Norwegian School of Theology: PhD Dissertation, 2009), 8 and $\mathrm{n}$. 27.

${ }^{208}$ The term " $\theta \varepsilon \circ \pi \circ \eta \eta \theta \tilde{\omega} \mu \varepsilon v "$ has various translations, such as "we might become God" or "become divine/gods", but in Athanasius's context, these expressions refer to the same divinised matter. For various translation versions, see Kaufman 2009, 7 and n. 24-25.

${ }^{209}$ Basil of Caesarea, On the Holy Spirit 9.23: "When a sunbeam falls on a transparent substance, the substance itself becomes brilliant, and radiates light from itself. So too Spirit-bearing souls, illumined by Him, finally become spiritual themselves, and their grace is sent forth to others. From this comes knowledge of the future, understanding of mysteries, apprehension of hidden things, distribution of wonderful gifts, heavenly citizenship, a place in the choir of angels, endless joy in the presence of God, becoming like God, and, the highest of all desires, becoming God". See Michael Christensen, "The Problem, Promise, and Process of Theosis", in Partakers of the Divine Nature: The History and Development of Deification in the Christian Traditions, ed., Michael J. Christensen and Jeffery A. Wittung (Grand Rapids, Michigan: Baker Academic, 2007), 23. Augustine Casiday translates the final sentence as: “...the being made like to God, and, highest of all, the being made God", see Casiday 2008, 170.

${ }^{210}$ Maximus Confessor, Book of Ambiguities 60. See Sherrard 1959, 44.

211 Maximus Confessor, Book of Ambiguities 41. Pelikan 1974, 267. Elizabeth Theokritoff comments, "Maximus speaks of deification as 'being identical with God'- but he makes it clear 
distinction indicates that "becoming God" does not mean being identical with God, thus increasing the "three hypostases" into "myriads of hypostases", but rather sharing and acquiring the uncreated powers of God in divine nature. Through participating in these commutable divine energies, we unite with the Trinitarian persons. As Lossky argues, "we do not ourselves become the divine hypostasis of the Son by the fact of the Incarnation. We are unable, therefore, to participate in either the essence or the hypostases of the Holy Trinity". ${ }^{212}$ Deification occurs through the energies and powers which are "common to the nature in Three [hypostases]". ${ }^{213}$ Thus, the distinction between essence and energy and the thesis of uncreated grace in energies is the crux of the matter of theosis for Eastern theologians. Keeping in mind this distinction, let us turn to Augustine's account of the "emotional" features of the citizens of Heaven in order to determine whether his vision is merely "untransformed" divinisation.

\section{Constant spiritual state by attaining the deity of eternality}

Augustine asserts that even though one can apply numerous attributes to God, such as "immortal, incorruptible, unchangeable, living, wise, powerful, beautiful, just, good, blessed, and spirit", they could be reduced to only three (eternal, wise, and blessed) or even just one, for the nature of God is simple. ${ }^{214} \mathrm{God}$ is the highest simplicity (summa simplicitas) as He told Moses, "I AM WHO I AM" (Exodus 3:14). ${ }^{215}$ His non-temporal eternity, Augustine explains, is without beginning and without end (sine initio, sine fine $)^{216}$, and it is compatible with other attributes, denoting the one and the same substance of God. ${ }^{217}$ Thus, the

that this is an identity in every respect apart from essence". Elizabeth Theokritoff, "Creator and creation", in The Cambridge Companion to Orthodox Christian Theology, ed., Mary B. Cunningham and Elizabeth Theokritoff (Cambridge: Cambridge University Press, 2008), 67.

${ }^{212}$ Lossky 1957, 70.

213 Ibid., 70.

214 De Trin. 15.5.8-15.6.9: Proinde si dicamus: “aeternus, immortalis, incorruptibilis, immutabilis, uiuus, sapiens, potens, speciosus, iustus, bonus, beatus, spiritus” ...Nam si una eadem que res in Dei natura potest esse sapientia et potentia aut uita et sapientia, cur non una eadem que res esse possit in Dei natura aeternitas et sapientia aut beatitudo et sapientia?

${ }^{215}$ De Trin. 6.5.7:...et si aequalis in omnibus aequalis propter summam simplicitatem quae in illa substantia est.

${ }^{216}$ De Trin. 15.5.7: Ipsa est etiam uera aeternitas qua est immutabilis Deus sine initio, sine fine, consequenter et incorruptibilis.

${ }^{217}$ De Trin. 15.6.9: Ac per hoc sicut nihil intererat utrum illa duodecim an ista tria diceremus quando illa multa in istam redegimus paucitatem, ita nihil interest utrum tria ista dicamus an illud unum in cuius singularitate duo cetera similiter redigi posse monstrauimus. Cf. De Trin. 15.5.8. 
eternal nature of God is the highest and ineffable essence that only the Trinitarian persons can share.

As a deificatory gift in Heaven, the nature of "eternality" will be bestowed upon human citizens by the grace of God. In the new heaven and earth, Augustine anticipates, "There we shall rest and see, see and love, love and praise. Behold what will be, in the end to which there shall be no end!"218 Acquiring the quality of eternity is a prerequisite for deification, which denotes that humans will be separated from the old corruptible life and be granted the immortality of God. It is more than the fulfilment of humanity, referring to a real transformation. However, eternity for humans is not non-temporal as it is for divine persons, which is indicated by Augustine's remarks on the mode of life of the resurrected persons in Heaven. Therefore, the transformation does not take place by becoming included in the divinity as is understood in Palamism. This divinised reality of eternal life is essentially distinguished from the previous human mortality and reflects the promise of God (2 Peter 1:4; Genesis 1:26-27; Genesis 3:5; Psalms 82:6; John 10:34-35; Matthew 5:48; and 2 Corinthians 3:18). ${ }^{219}$ In his Enarrationes in Psalmos 101.2.10, Augustine explains:

God's years will exist in us...In the same way that God himself will be in us...God's years are not something different from God himself. God's years are God's eternity, and eternity is the very substance of God, in which there is no possibility of change. ${ }^{220}$

The statement "God's years will exist in us" connotes that humans will come to participate in the divine eternity. This provides them with immortality, "the end to which there shall be no end!" 221 But it is not meant that sharing an unending life makes human eternity identical with that of the Trinitarian persons (hypostases) who are beyond time and create time. The adopted "gods" have experienced a past mortal lifetime before being divinised, and after adoption, the human mode of an unending life is to participate in the atemporal eternity insofar as it is possible for created beings who are not atemporal. Augustine does not explain the nature of

\footnotetext{
${ }^{218}$ CD 22.30: Ibi uacabimus et uidebimus, uidebimus et amabimus, amabimus et laudabimus. Ecce quod erit in fine sine fine.

${ }^{219}$ For the Scriptural passages related to the promise of theosis, see Christensen 2007, 24.

${ }^{220}$ See also David Vincent Meconi, S.J., "Heaven and the ecclesia perfecta in Augustine", in The Cambridge Companion to Augustine (second edition), ed. David Vincent Meconi and Eleonore Stump (Cambridge: Cambridge University Press, 2014b), 253.

${ }^{221} C D 22.30$.
} 
this atemporal aspect of the life of resurrected persons. What remains particularly unclear is how the resurrected body functions. Augustine states: "When the body is made incorruptible, all the members and inward parts which we now see assigned to their various necessary offices will join together in praising God; for there will then be no necessity, but only full, certain, secure and everlasting felicity". ${ }^{222}$ Augustine thinks that the central burden of an emotional life is one's uncertainty of the future and that this uncertainty results in fear and changeable passions, disturbing one's tranquility. These sources of emotional trouble disappear when one participates in divine eternity and when one has the unchanging divine matters as the continuous content of cognition in Heaven. Another factor of the freedom from passions is the improvement of the soul and the psychosomatic balance of the resurrected person. ${ }^{223}$

\section{The attainment of divine joy by the operations of the Holy Spirit}

The deified human beings will participate in the Trinitarian life through the bond of divine love, in which the Holy Spirit functions as the love that joins not only the Trinitarian persons but also humans. ${ }^{224}$ It is noteworthy that Augustine regards the gift of the Spirit and the Holy Spirit as a person of the Trinity as the same divinity. He states this principle clearly in De Trinitate 15.19.36:

Since they already see that the Holy Spirit has been called the Gift of God, consequently, we must warn them that...the Gift of the Holy Spirit is nothing else than the Holy Spirit. $\mathrm{He}$ is, therefore, the Gift of God, inasmuch as $\mathrm{He}$ is given to those to whom $\mathrm{He}$ is given... Nor because they[the Trinity] give and $\mathrm{He}$ is given is $\mathrm{He}$, therefore, less than they, for He is so given as the Gift of God that He also gives Himself as God. For it is impossible to say of Him that $\mathrm{He}$ is not the master of His own power...And in the writings of the Apostle which I have mentioned above: "And one and the same Spirit works, dividing what is proper to each one according as he will." There is here no subordination of the Gift and no domination of the Givers, but the concord between the Gift and the Givers. ${ }^{225}$

${ }^{222}$ CD 22.30: Omnia membra et uiscera incorruptibilis corporis, quae nunc uidemus per usus necessitatis uarios distributa, quoniam tunc non erit ipsa necessitas, sed plena certa, secura sempiterna felicitas, proficient laudibus Dei.

${ }^{223}$ For a discussion on the heavenly tranquility of the soul in Augustine, see King 2012a, 20-21.

${ }^{224}$ See section 5.5 .

${ }^{225}$ De Trin. 15.19.36: Sane admonendi sunt quandoquidem Donum Dei iam uident dictum Spiritum Sanctum...Donum Spiritus Sancti nihil aliud est quam Spiritus Sanctus. In tantum ergo Donum Dei est in quantum datur eis quibus datur...Nec quia illi dant, ipse datur, ideo minor est 
This same divinity ensures that when the Spirit works in a human soul, the soul is also made divine. Through this operation, which Augustine refers to as grace (gratia), the substance of humans will be "changed into something better" (mutatur in melius) when they become sons of God; God, on the other hand, becomes their Father without any change in His substance. ${ }^{226}$ The adoptive children of God include both men and women who will retain their gender in the resurrection. ${ }^{227}$ For Augustine, the power (ops) that fills the renewed human heart is the Holy Spirit who is given to us. ${ }^{228}$ This means that we receive a supernatural influence that renews us toward perfection. Augustine emphasises the role of divine operations in the process of salvation and deification. In Confessions, he describes the ecstatic experience that he refers to as "the first fruits of the Spirit" (primitias Spiritus) as follows:

Our minds were lifted up by an ardent affection towards eternal being itself. Step by step we climbed beyond all corporeal objects and the heaven itself, where sun, moon, and stars shed light on the earth... We moved up beyond them so as to attain to the region of inexhaustible abundance where you feed Israel eternally with truth for food... That is how it was when at that moment we extended our reach and in a flash of mental energy attained the eternal wisdom which abides beyond all things. If only it could last, and other visions of a vastly inferior kind could be withdrawn! Then this alone could ravish and absorb and enfold in inward joys the person granted the vision. So too eternal life is of the quality of that moment of understanding after which we sighed. Is not this the meaning of "Enter into the joy of your Lord"? 229

illis. Ita enim datur sicut Dei Donum ut etiam Se ipsum det sicut Deus. Non enim dici potest non esse suae potestatis de quo dictum est...et apud Apostolum quod iam supra commemoraui: Omnia autem haec operatur unus atque idem Spiritus diuidens propria unicuique prout uult. Non est illic conditio Dati et dominatio Dantium sed concordia Dati et Dantium.

${ }^{226}$ De Trin. 5.16.17: Sic et Pater noster esse incipit cum per Eius gratiam regeneramur quoniam dedit nobis potestatem filios Dei fieri. Substantia itaque nostra mutatur in melius cum filii Eius efficimur; simul et ille Pater noster esse incipit, sed nulla suae commutatione substantiae.

${ }^{227}$ CD 22.17: Sed mihi melius sapere uidentur, qui utrumque sexum resurrecturum esse non dubitant...Qui ergo utrumque sexum instituit, utrumque restituet.

${ }^{228}$ nat. et gr. 84: Ubicumque autem et quandocumque ita plena sit, ut ei non sit quod adiciatur, non tamen diffunditur in cordibus nostris uel naturae uel uoluntatis opibus quae sunt in nobis, sed per Spiritum Sanctum qui datus est nobis, qui et infirmitati nostrae opitulatur et sanitati cooperatur.

${ }^{229}$ Conf. 9.10.24-25:...erigentes nos ardentiore affectu in id ipsum perambulauimus gradatim cuncta corporalia et ipsum caelum, unde sol et luna et stellae lucent super terram ...transcendimus eas, ut attingeremus regionem ubertatis indeficientis, ubi pascis israhel in aeternum ueritate pabulo... sicut nunc extendimus nos et rapida cogitatione attingimus aeternam sapientiam super omnia manentem, si continuetur hoc et subtrahantur aliae uisiones longe imparis generis et haec una rapiat et absorbeat et recondat in interiora gaudia spectatorem suum, ut talis sit sempiterna 
The words "ardent affection" (ardens affectus) refer to the operation of the Spirit. By being filled with divine presence, the soul is elevated to a mysterious realm of inexhaustible abundance and experiences inexplicable rejoicing. During this process, Augustine distinguishes between the elevating power of the Spirit and the eternal wisdom that the soul attains. This distinction refers to the roles of the Spirit and the Wisdom in bringing humans into a perfect union with divine nature. Through the reception of the Holy Spirit, the soul is united with the indwelling Spirit and the work of grace begins. ${ }^{230}$ This union, however, is unstable, and the believer longs to be improved by the Spirit to achieve a perfect and perpetual union with the Trinity. As Augustine remarks, the divine ecstasy is momentary, but he wishes it could last forever.

Augustine hopes that the earthly ecstasy will be transformed into a divine joy in Heaven by the sustained operations of the Spirit. In the final part of his work De civitate Dei, Augustine describes this heavenly joy as "constant enjoyment of the happiness of eternal joys" (fruens indeficienter aeternorum iucunditate gaudiorum), characterised by copious positive qualities such as wellordered peace, an absence of deficiencies, abundant goodness, eternal felicity, and conforming to one's free will. ${ }^{231}$ The concepts included in Augustine's description, "eternal joys", "enjoyment of the happiness", and "constant enjoyment", refer to a subjective feeling of happiness about participating in divine, eternal joys. Augustine argues that this constant joy is free from the delight of sinning and has the new freedom of will of not being able to $\sin .^{232}$ This is owing to the grace that permits the adopted gods to participate in divine nature:

uita, quale fuit hoc momentum intellegentiae, cui suspirauimus, nonne hoc est: intra in gaudium Domini tui?

${ }^{230}$ Augustine adds in his later works that attaining the grace of divinity actually begins at the first dwelling of the Spirit. See De peccatorum meritis et remissione 2.8.10 (dated 411): "We now have the first fruits of the Spirit, and in that respect we have now really become the children of God"; De perfectione justitiae hominis 7.16 (dated 415): "The perfection of this work of grace is even now being realized in those who are making progress, and it will attain total fulfillment". For a detailed account of this point, see Meconi 2014b, 268-269. On this basis, Meconi offers the slogan: "Heaven even on earth". Ibid., 268-270.

${ }^{231} C D$ 22.30: Erit ergo illius ciuitatis et una in omnibus et inseparabilis in singulis uoluntas libera, ab omni malo liberata et impleta omni bono, fruens indeficienter aeternorum iucunditate gaudiorum, oblita culparum, oblita poenarum.

${ }^{232}$ Augustine emphasises that there is gradation of grace in granting free will to humans. For the first human beings, their human nature has the power to sin, but in Heaven, the redemptive men will receive a "more abundant gift of grace", the impossibility to $\sin$. CD 22.30: Magis quippe erit liberum a delectatione peccandi usque ad delectationem non peccandi indeclinabilem liberatum... 
For it is one thing to be God, and another to be a partaker of God: God is by nature unable to sin; but he who partakes of God's nature receives the impossibility of sinning only as a gift from God. ${ }^{233}$

Augustine depicts becoming God as participating in God's nature. Only by sharing the divine nature by grace can humans be granted their freedom from $\sin .^{234}$ Yet they are not equal to the Trinitarian persons and they do not increase the number of the three hypostases. Desiring to become God in this sense (becoming a hypostasis) is completed rejected by Augustine:

But when we are restored by Him and perfected by His greater grace, we shall be still for all eternity, and know that He is God, being filled by Him when He shall be all in all. ${ }^{235}$

Two principles are established here concerning the relationship to God. The first principle is that we shall be filled with the divine power and thus participate in His divinity; the second principle is that God's essence remains transcendent when we see the Trinity face-to-face. The first principle states that by the Spirit operating, the deification will take place and we shall receive greater grace in Heaven to achieve the deified reality in communion with the Trinitarian persons through divine love. The term "gratia maiore" ("greater/more grace") refers to the genuine deified transmutation into a better substance (substantia itaque nostra mutatur in melius) $)^{236}$ in the union with God. Due to the better form of our human substance, we receive a new freedom of will (being unable to sin), a tranquility of mind through participation in divine eternality, and constant joy in the fruition of God in the beatific vision. All these are gifts evidently superior to both the previous stage of the first human beings in Paradise and such a restoration of humanity that would still permit the possibility to sin.

The second principle defines deification as not becoming a person of the Trinity. The transformation of the substance, in which the personal identity is retained, results in a new creature who lives in a community with the Trinitarian

sed quia peccauit ista natura cum peccare potuit, largiore gratia liberatur, ut ad eam perducatur libertatem, in qua peccare non possit.

${ }^{233}$ CD 22.30: Aliud est enim esse Deum, aliud participem Dei. Deus natura peccare non potest; particeps uero Dei ab illo accepit, ut peccare non possit.

${ }^{234} C D$ 22.30: Seruandi autem gradus erant diuini muneris, ut primum daretur liberum arbitrium, quo non peccare homo posset, nouissimum, quo peccare non posset, atque illud ad comparandum meritum, hoc ad recipiendum praemium pertineret.

235 CD 22.30: A quo refecti et gratia maiore perfecti uacabimus in aeternum, uidentes quia ipse est Deus, quo pleni erimus quando ipse erit omnia in omnibus.

${ }^{236}$ See De Trin. 5.16.17, quoted in note 226. 
persons, but the transformed substance is made by God, not a constitutive part of God. Augustine conveys in his interpretation of deification that although there is a communion with the Trinity through the divine bond of the Holy Spirit, the transformed substance will still remain as an imago Dei.

When Augustine discusses the simplicity and indivisibility of God, he refers to God's essence, which is transcendent and incommunicable. However, there is another level of the divine operation of the Spirit that shapes the believers' divinised life. Augustine speaks about the "first fruits of the Spirit" (the gift of the Spirit being the real presence of the Spirit itself) where the soul has received the divine power and is united with the divinity, progressing toward the final consummation. This is more than the fulfilment of humanity as it is mistakenly understood by Augustine's Eastern critics. Instead, it refers to a genuine elevation by grace, in which the human substance is transformed into a better form, although not equal to Trinitarian persons. To avoid any misconception of this type of deification, Augustine formulates this as "becoming like God". Many of Augustine's formulations, such as the real presence of the Spirit and the transformation of the substance, seem not very far from the Orthodox notion of "becoming God" by attaining divine nature through uncreated energies. Both admit the basic fact that the Trinitarian essence (ousia) is inaccessible and explain the mode of the union with God by stating that our nature is transformed. In brief, the assertion that Augustine's paradigm is "toward beatitude, not deification" is not well-founded. However, the theological details of the supranaturally caused transformation in these traditions are beyond the scope of this study. ${ }^{237}$

I have explored Augustine's approach to the deification of emotions and analysed his perspective on how humans could become free from earthly passions and attain the deificatory realm. In the fallen state, the Trinitarian relations and "emotions" are inscrutable and ineffable for human beings, but this is not to say

\footnotetext{
${ }^{237}$ For a comparison of theosis in Augustine and Palamas and his followers, see Gerald Bonner, “Augustine's Conception of Deification", in Journal of Theological Studies 37 (1986), 369-386; George E. Demacopoulos and Aristotle Papanikolaou, "Augustine and the Orthodox: 'The West' in the East", in Orthodox Readings of Augustine (Crestwood, New York: St. Vladimir Seminary Press, 2008), 11-40; David Vincent Meconi, The One Christ: St. Augustine's theology of Deification (Washington: The Catholic University of America Press, 2013).
} 
that they are entirely inscrutable or irrelevant to present human life. In order to attain a general picture of the triune life, Augustine attends to relational phenomena in human psychology such as self-reflexivity as well as to emotions in the image of God. The psychological approach provides some sporadic ideas of the Trinity, but they remain obscure. Only by virtue of the person of Christ, who bridges the divine and human emotions through His kenosis and divine transaction, can humans abandon their miserable emotions in this life and attain the divine spiritual perfection that represents the advent of deification. The soteriological approach to the improvement of the will and emotions is essentially detached from a human initiative and is wholly dependent on God's salvation. God will give the gift of the Spirit to believers to elevate them to the divine realm in a perfect union with God. This deification through redemption and grace does not make humans a hypostasis of the Trinity, nor does it stop at the beatitude of humanity, but rather includes a real transformation of humanity into a better form by participating in the triune spiritual life through the bond of the Holy Spirit. 



\section{CHAPTER SIX: CONCLUSION}

In the introductory Chapter, I defined the main objective of this study, which was to provide a systematic analysis of Augustine's conception of passions and his approach to the salvation from their domination as well as the sanctification of passions.

Chapter 2 presents an analysis of the language of passions in Augustine's texts to determine the historical background of his terminology. Augustine followed Cicero, the Platonists and the Stoics in envisioning passio as a perturbation of the soul which is, or tends to be, contrary to reason. Moreover, Augustine's use of passio and its four subspecies (desire, fear, joy, and grief) displays a sound understanding of received doctrines. Contrary to what is sometimes suggested, there is no textual evidence for a systematic dichotomy in his texts that passio is negative and affectus is positive. Instead, he employed these terms rather flexibly, often using passio in a negative sense, but occasionally also in a positive sense, and while he referred to affectus as both a positive and a negative term, Augustine also used passio, affectio, and perturbatio interchangeably. Furthermore, he was flexible in his usage of the subcategories of passio (cupiditas, laetitia, metus, and tristitia) and constantiae (voluntas, gaudium, cautio) in either a good or a bad sense. Occasionally, Augustine even utilised passio and other related terms interchangeably to express all types of emotions.

It is also important to mention that Augustine employed the concept of "godly passions" to demonstrate that Christian passions can be regarded as being good. In this case, passions are tools for Christians to improve their dispositions and foster virtues. We see that Augustine shifted the discussion on the semantics of passions to a new domain, focussing on theological conceptions such as will and love in weighing the quality of passions. If love and will are righteous, then passions must also be righteous, and if they are evil, the passions are perversely directed. In this context, the lexical meaning of passio becomes less important, giving way to the underlying motivation and love as a new set of criteria. The transition of the evaluation focus denotes that Augustine's consideration goes beyond the scope of philosophical discussions. 
After analysing the usage of passio and other related terms in Augustine's texts, I turned to the doctrinal background of Augustine's psychology of passions that adhered to two crucial schools, Neoplatonism and Stoicism. I examined the doctrinal connections between these and Augustine as well as his connections to earlier Christian thinkers such as Clement, Origen, Antony, Evagrius, Jerome, Ambrose, and the Cappadocian Fathers. While it is not difficult to detect some traces of their influence in Augustine's texts, the references are often fragmentary and ambiguous, as Augustine did not fully commit himself to the teachings of any of these predecessors. He eclectically applied two influential traditions, Platonism and Stoicism, transforming their terminologies and psychology of passions from his own Christian perspective. After surveying these doctrinal sources, I proceeded to the subject of controlling and moderating passions to consider how Augustine integrated his predecessors' therapy of passions and their ideal of freedom from emotion in his own theory, and I attempted to determine whether he misunderstood their doctrines during in his approach.

In Chapter 3, I examined a range of controversial conceptions related to the notion of freedom from passions, such as propatheia, metriopatheia, apatheia, and eupatheia, by tracing Augustine's views throughout his works. I have demonstrated that intricate changes occurred in his thinking during the different stages of his life. Augustine's views are not accurately reflected by either the allegation that he misunderstood his predecessors, or the argument that he simply adhered to Stoic or Platonic doctrines. For instance, in his account of propatheia in $C D$ 9.4, Augustine deliberately changed the phrase by Gellius of "motibus rapidis et inconsultis" into "his passionibus praevenientibus". He did not adopt the Stoic position on first movements as innocent reactions to images (phantasia) or visions (visum), nor did he abide by his own early- and middle-period position that was in line with the Stoic criticism of passions. Augustine interpreted first movements as "passions" in his late works, attributing some of the first movements experienced by believers, such as fear, desire, or anger, to a psychological state of momentary infirmity, hesitation, and doubt that result from insufficient faith in God. According to Augustine, first movements ultimately derive from original sin, but they are not regarded as personal sins or evils if they 
are expelled as soon as possible. Thus, Augustine refuted the Stoic "pride" that suggested that the wise can resist the agitations of involuntary passions, deeming it incompatible with his own theological perspective.

Augustine continued to argue that no substantial difference exists between metriopatheia and apatheia in the Stoics and the Peripatetics and that their controversies concerning these terms were nonsensical. The Stoic ideal of freedom from emotion (apatheia) and the Platonic therapy of passions (metriopatheia) appealed to Augustine in his early and middle works, and he advocated their teachings on controlling one's passions through intellectual acts. However, Augustine later changed his position, referring to the Stoic apatheia as insensitivity. He maintained that the alleged virtues of the Stoics and Platonists are in fact vices that represent injustice, arrogance, and inhumanity, and provide no acceptable criteria for evaluating the quality of passions. In Augustine's late theological interpretations, the philosophical therapies aiming at metriopatheia and apatheia were modified in light of the model of Christ. This means that as the mediator between God and humans, Christ deliberately undertakes human passions in order to implement God's redemptive plan of saving humans from passions and their sinful condition in general, presenting the perfect unity of divine impassibilitas and human sensibility. In comparison to the passion of Christ and His saving work, the philosophical controversies over apatheia and metriopatheia become non-essential.

Augustine was interested in the essence of eupatheia in the Stoics. In his early works, he adopted the Stoic position and regarded eupatheia as a rational as well as tranquil state of mind. This is characterised by indifference towards external matters and by an ability to make morally right judgements that result in genuine goodness. Thus, indifference as a connotation of the Stoic notion of wise eupatheia needs to be distinguished from the fools' irrational reactions and imprudent behaviour. Later, however, Augustine equated the Stoic eupatheia with stupor because he was not convinced of the human ability to achieve this ideal state. This doubt was based on his pessimistic theological interpretation of the human condition.

By analysing Augustine's uses of the four conceptions above, it becomes 
evident that Augustine deviated from the philosophical framework and introduced a theological synthetic evaluation. However, he continued to employ philosophical terminology in his late theology. This may have led to the misjudgment that Augustine "misrepresented" philosophical doctrines, particularly if one is not aware that they have been applied through new connotations to Christian values. In other words, Augustine did not completely adhere to any of his philosophical predecessors. Instead, he offered a theological anthropology developed from a different perspective by reinterpreting the terminology and doctrines of his predecessors accordingly. Based on these observations, I presented the outlines of Augustine's theological framework of passions, identifying two crucial concepts, original sin and grace, and discussed his understanding of the uncontaminated values of Christ (Chapter 3.4). Before I proceeded to a more detailed discussion on the theological context of passions in Augustine, I provided a general overview of how he addresses emotions on the basis of his framing of philosophical theories (Chapter 3.5).

In the light of Augustine's theological anthropology, I turned to the domain of social life to examine his notion of freedom from passions in the earthly city (Chapter 4). Following Augustine's conception of the three levels of the human society, domus, ciuitas, and orbis terrae, I argued that he discerned two loves, caritas and cupiditas, as distinct characters of the two cities, regarding the passion for egoistic glory or pride as a sign of the fallen state that perversely mirrors the authority of God in exercising a lustful dominion. An important theme for Augustine was how one frees oneself from these rapacious passions to attain spiritual perfection. Rejecting all human initiatives and alleged merits, Augustine emphasised that only divine grace would be able to transform depraved passions into a gracious emotional state (voluntas praeparatur a Deo). However, the question as to how this can be reconciled with the freedom of the human will, which Augustine also argued for, remains unresolved. To Augustine, it is through grace that an improvement in renewed passions may become a gradient ascent process that abandons the libido dominandi and instead cultivates virtues as a consequence of divine love. Nonetheless, Augustine held the pessimistic view that this improvement of passions cannot attain perfection on earth and refuted the 
pacifists who tolerated the evils of this world in order to maintain temporal peace. His notion of fighting against lust domination with gracious emotions does not imply that he was either a pacifist or a militarist, but rather that he was anchored in a religious position, defending the faith of the Heavenly Kingdom where the cupiditas should be completely transformed into caritas through the enjoyment of God.

Augustine's social theory is based on the concept of two cities as well as the underlying notion of two distinct loves. The concepts of corpus permixtum and peregrinatio describe the terrestrial state of the sacred Heavenly City, which represents an intermediate stage of its evolvement. From the origin to the end, self-love is regarded as the dominant characteristic of the fallen city. So the fundamental issue in Augustine's social theory is the question of how to turn the perverse direction of desire from lower objects back to the supreme good. Against this theological background, Augustine presented his insight into renewing passions by following three central ideas.

As regards concupiscence and continence, Augustine refuted the notion of sinlessness proposed by Pelagius and Julian, arguing that concupiscentia is an innate evil affection that is present in infants as the result of original sin. He distinguished between three phases of renewal, highlighting the fundamental role of grace throughout the process and the participatory function of the obedient will in the intermediate stage, which represent phases one and two, respectively. During the third phase, there will be various fruits in virginity and chastity, but they are merits provided by God, who creates the virtues of passions that form new, good lifestyles. Moreover, by pouring love into one's heart, the grace of the Holy Spirit cultivates different inward dispositions, which result in an improvement of one's inner life and an ascent of love. Augustine therefore argued that true virginity and chastity do not exist in this life when compared to the model of Christ. They can be regarded as merits in the sense of being various gifts from God.

Concerning ecclesiastical elitism and secularism, Augustine rebuked the Donatist schismatic doctrines of rebaptism, purism, and martyrdom, emphasising the hybridity of the Dove (columba) of Christ on earth. He argued that the effect 
of baptism derives from the merits of Christ rather than those of priests, and that martyrdom does not entail external fame for a fanatically defended "elite" group, but rather is an attempt to attain the unity of Christ in patience and love. It is clear that to provide an ordinate spirituality of emotions, Augustine shifted to inwardness. To Augustine, the suffering of Christ provides the perfect model for martyrs, monks, and the laity, and those that follow Him display different grades of renewed emotions. Augustine did not strictly distinguish between the lifestyles of monasteries and the outside world, but he did compose several rules to aid practitioners in developing consecrated love when encountering the temptations of this world. In this sense, he did not approve of clergies who are involved with civil affairs, neglecting their monastic meditations.

Concerning earthly war and peace, Augustine replied to the Manichaean accusation that the new commandment of Christ contradicts the command of God in the old times. He argued that the real evils of war are lustful passions, whereas true peace is found in the future Kingdom of God; the distinction between one's inward personal attitude and the requirements of a just war is necessary in the military service. In addition, he believed that a gracious inward feeling does not contradict the struggle against evil with just violence, and that this is consistent with the Law and the Gospel. Thus, Augustine believed that Christ's teaching of "turning the other cheek" presents the idea of the renewal of inward disposition and emotions.

Augustine formulated a ranking of consecrated attitudes and emotions, adopting Christ's passions as a perfect model. Moreover, Augustine considered virtuous modes of life as not being human merits, but the work of Christ who sends out the grace of love to cultivate different levels of the human mind. This means that by virtue of grace, one will acquire the power to control evil desires and gradually ascent to the perfection of spirituality in the future Heavenly City. In this pilgrimaging life, instead of seeking one's own power or idolatry on earth, the citizens of ciuitas Dei peregrina will direct their will and passions toward the supreme good and follow the perfect model of Christ.

Chapter 5 addressed the issue of how to understand the "emotions" of God and to attain the divine realm in an effort to free oneself from the perturbations of 
emotions. For Augustine, the triune psychology of "emotions" transcends human knowledge and comprehension, but this does not imply that it is entirely inscrutable in this life. To conduct this type of exploration, an appeal to human psychology and to passions might be helpful because, as part of the imprints of God in humanity, human passions serve as an indicator of divine psychology. Augustine provided a psychological approach for envisioning the Triune life with respect to the doctrine of imago Dei. Augustine's position was that the tranquility of the original human soul displays some traces of a divine immutable spiritual status, but this image of God was distorted when the first men transgressed the law and this led their created peaceful minds to experience perturbations. Thus, Augustine maintained that human passions are not a direct reflection of divine psychology, but a confused image of God's "emotions". This means that any approach to trace the psychology of God can neither involve constructing a direct analogical parallel from the human point of view, nor interpreting the scriptural utterances of God's passions as being literally true. In this sense, divine (im)passibility is a metaphorical conception that should not be interpreted as an emotional or impassible psychology as in humans. Instead, divine (im)passability serves as an apophatic qualifier to refer to the transcendence and immutability of God.

Augustine argued that a real approach to the divine realm and to the triune spiritual life is through the salvation of the person of Christ. As the mediator between divinity and humanity, the "impassible" person of Christ takes on human sufferings to make a transaction of emotions, absorbing all human sufferings and granting His divine spiritual nature to sinners. The person of Christ does this in order to deliver humans to the deified realm. In this divine transaction, the divine and human natures are both separate and inseparable in the crucified person of Christ. Thus divine and human emotions are both associated with Jesus Christ, without division, confusion, transformation or separation. This divine involvement in human emotions through the incarnation and crucifixion of the second person of the Trinity reveals a deeper theological theme, the deification of emotions as a salvation. The divine kenosis contains the redemption of human beings from their miserable earthly emotions to the deified state of participation 
into the divine spiritual nature, so that the divine economy of salvation involves the deification of emotions.

As we have witnessed, Augustine considered emotions to be perturbations of the soul that are essentially unworthy of God, and he maintained that it will be through suffering that the demons and their human followers will be punished in Hell. Augustine's position is that anguish and torment in the lake of fire are not therefore merely metaphorical, but they involve the real misery of eternal condemnation. In contrast to this pain, Augustine believed that the Heavenly human citizens will be divinised as adopted sons of God, participating in the inner divine life and showing an eternal fruition of God by the bond of the Holy Spirit. Furthermore, they will be constantly rejoicing in their union with God and this signifies the attainment of the divine spiritual reality, but the gulf between dii and Deus will remain clear. According to Augustine, the deified human citizens will be fully filled with the Holy Spirit and become the perfect likeness of God as an image of Him. But they will not replace their substance with that of the Trinitarian persons. Furthermore, it is evident that Augustine based this vision of deification on the doctrine of the imago Dei.

However, it is misleading to claim that due to Augustine's blindness to the divine essence/energy distinction, his theory of deification is merely a matter of the fulfillment of humanity without a genuine transformation. As we have seen, the divine economy of salvation involves the process of delivering humans and granting them the freedom from passions in the divinisation in the City of God. For Augustine, this divinised approach begins from "the first fruits of the Spirit" when the human soul receives the divine powers from the real presence of the Holy Spirit. Through the Spirit's sustained operations as well as through the redemption of Christ as mediator, the sinners will be gradually become disengaged from the bondage of the earthly disturbances of their passions and share divine joy in their perfect union with God in Heaven. Three divinised characterisations of emotions, that is, a new freedom of the will from the possibility of sinning, eternal and immutable spiritual life, and the constant rejoicing and full rest in God, all convey that the substance of humanity has been transformed into something better. This means that the saved ones have achieved 
real participation in divine spiritual life, which is more than re-establishing the human nature and emotions that existed in the original good state in paradise. This substantial transformation is involved in Augustine's concept of "greater grace" (gratia maiore). To avoid the blasphemous assumption of changing the substance of humanity into the person of the Trinity, Augustine adopted a prudent approach of "becoming like God", which should not be misinterpreted, as some critics have, as a wrong deification theory of simple "beatitude of humanity".

It is clear that Augustine's ideal of freedom from passions points to the deification of emotions in his late theology. He had learned the philosophical predecessors' theories of the soul and their therapeutic techniques to control emotions, but their approaches to the ideal of peace of mind proved to be problematic in Augustine's later evaluations. Instead of appealing to a human initiative when he addressed the issue of passions, Augustine designated the central role to grace. Furthermore, he argued that an important aspect of the divine economy of salvation is an emotional transformation in which the sinners will be delivered to the divine realm and they will participate in the triune spiritual life as a hallmark of divinisation. To summarise, Augustine's vision of the future City of God implies the notion of freedom from passions and the deification of emotions with real participation in the divine spiritual nature. 



\section{BIBLIOGRAPHY}

\section{Abbreviations}

CCL Corpus Christianorum, Series Latina. Turnhout: Brepols, 1953-.

CSEL Corpus Scriptorum Ecclesiasticorum Latinorum. Vienna: Tempsky, 1865-.

PL Patrologiae Cursus Completus, Series Latina (ed. J.P. Migne). Paris: Garnier, 1844-64.

PLS Patrologiae Cursus Completus, Series Latina, Supplementum (ed. A. Hamman). Paris:

Garnier, 1958-74.

PG Patrologiae Cursus Completus, Series Graeca (ed. J.P. Migne). Paris: Garnier, 1857-66.

NKJV Holy Bible (New King James Version). Nashville: Thomas Nelson, 1985.

1. Augustine

an. et or

De anima et eius origine

On the Soul and Its Origin

b. coniug.

De bono coniugali

On the Good of Marriage

b. uita

De beata uita

On the Happy life

bapt.

De baptismo

On Baptism

c. Acad.

Contra Academicos

Against the Skeptics

c. ep. Man.

Contra epistulam Manichaei

Against the "Foundation Letter"

quam uocant fundamenti

of the Manichees

c. ep. Parm.

Contra epistulam Parmeniani

Against the Letter of Parmenian

c. ep. Pel. Contra duas epistulas Pelagianorum Against Two Letters of the Pelagians

c. Faust. Contra Faustum Manichaeum

Against Faustus, a Manichee

c. Gaud.

Contra Gaudentium

Against Gaudentius

c. litt. Pet.

Contra litteras Petiliani

Against the Letters of Petilianus

c. Iul. imp.

Contra Iulianum opus imperfectum Against Julian, an Unfinished Book

c. Iul.

Contra Iulianum

Against Julian

cat. rud.

De catechizandis rudibus

On the Instruction of Beginners

$C D$

De civitate Dei

City of God

Conf.

Confessiones

Confessions

correct. De correctione Donatistarum

On the Correction of the Donatists

corrept.

De correptione et gratia

On Admonition and Grace

De Trin.

De Trinitate

The Trinity

doc. Chr.

De doctrina Christiana

Christian Teaching

En. Ps.

Enarrationes in Psalmos

Explanations of the Psalms

ench.

Enchiridion ad Laurentium

A Handbook on Faith, Hope, and Love

de fide spe et caritate

ep. Io.

In epistulam Ioannis

Tractates on the First Letter of John

ad Parthos tractatus

Ep.

Epistulae

Letters

ex. prop. Rm. Expositio quarumdam propositionum Commentary on Statements in the Letter to 
ex epistula apostoli ad Romanos the Romans

\begin{tabular}{|c|c|c|}
\hline gest. Pel. & De gestis Pelagii & On the Deeds of Pelagius \\
\hline Gn. litt. & De Genesi ad litteram & On the Literal Interpretation of Genesis \\
\hline Gn. adv. Man. & De Genesi adversus Manichaeos & On Genesis, against the Manichees \\
\hline gr. et lib. arb. & De gratia et libero arbitrio & On Grace and Free Will \\
\hline gr. et pecc. or. & \multicolumn{2}{|c|}{ De gratia Christi et de peccato originali On the Grace of Christ and Original Sin } \\
\hline haer. & De haeresibus & On Heresies \\
\hline imm. an. & De immortalitate animae & On the Immortality of the Soul \\
\hline Io. eu. tr. & In Iohannis Euangelium tractatus & Tractates on the Gospel of John \\
\hline lib. arb. & De libero arbitrio & On Free Will \\
\hline mag. & De magistro & On the Teacher \\
\hline mor. & $\begin{array}{l}\text { De moribus ecclesiae catholicae } \\
\text { et de moribus Manichaeorum }\end{array}$ & $\begin{array}{l}\text { On the Catholic and the Manichaean Ways } \\
\text { of Life }\end{array}$ \\
\hline mus. & De musica & On Music \\
\hline nat. $b$. & De natura boni & On the Nature of the Good \\
\hline nat. et $g r$. & De natura et gratia & On Nature and Grace \\
\hline nupt. et conc. & De nuptiis et concupiscentia & On Marriage and Concupiscence \\
\hline ord. & De ordine & On Order \\
\hline pat. & De patientia & On Patience \\
\hline pecc. mer. & De peccatorum meritis et remission & ne On the Punishment and Forgiveness of Sins \\
\hline perf. just. & De perfectione justitiae hominis & On the Perfection of Human Righteousness \\
\hline ps. c. Don. & Psalmus contra partem Donati & Psalm against the Donatists \\
\hline praed. sanct. & De praedestinatione sanctorum & On the Predestination of the Saints \\
\hline$q u$. & Quaestiones in Heptateuchum & Questions on the Heptateuch \\
\hline quant. anim. & De quantitate animae & On the Greatness of the Soul \\
\hline Retr. & Retractationes & Reconsiderations \\
\hline s. Dom. mon. & De sermone Domini in monte & On the Lord's Sermon on the Mount \\
\hline s. uirg. & De sancta uirginitate & On Holy Virginity \\
\hline Serm. & Sermones & Sermons \\
\hline spir. et litt. & De spiritu et littera & On the Spirit and the Letter \\
\hline util. cred. & De utilitate credendi & On the Advantage of Believing \\
\hline uera rel. & De uera religione & On True Religion \\
\hline
\end{tabular}

2. Other Authors

Ambrose

off. De officiis ministrorum On the Duties of the Clergy

Iac. De Iacob et beata uita On Jacob and the Happy Life

Aristotle

Eth. Nic. Ethica Nicomachea Nicomachean Ethics

Rhetor. Ars rhetorica Rhetoric

Aulus Gellius 
Noct. Att. Noctes Atticae

Cicero

Tusc.

Tusculanae disputationes

Defini.

Definibus bonorum et malorum

Clement of Alexandria

Strom.

Stromata

Diogenes Laertius

Vitae.

Vitae philosophorum

Gregory of Nyssa

Vit. Moys.

De vita Moysis

ani. et res.

De anima et resurrectione

Jerome

Comm. Math. Commentariorum in Matheum

Origen

Comm. in Matth. Commentarius in Matthaeum

De princ.

De principiis

Plato

Phaedr

Phaedrus

Philebus

Phile.

Rep.

De Republica

Plotinus

En.

Enneades

De abstinentia

abstin.

Seneca

ira.

De ira

Virgil

Aen.

Aeneis
The Attic Nights

Tusculan Disputations

Definitions of Good and Bad

Patchwork

Lives of Eminent Philosophers

About the Life of Moses

The Soul and the Resurrection

Commentary on Matthew

Commentary on Matthew

First Principles

Phaedrus

Philebus

Republic

Enneads

On Abstinence

On Anger

The Aeneid

\section{Translations}

1. Augustine

Atkins, E. M.

2001

Augustine: Political Writings (ed. E. M. Atkins and R. J. Dodaro). Cambridge:

Boulding, Maria Cambridge University Press.

2000a Expositions of the Psalms, 1-32, transl. Maria Boulding and ed. John E. Rotelle. The Works of Saint Augustine III/15. New York: New City Press.

2000b Expositions of the Psalms, 33-50, transl. Maria Boulding and ed. John E. Rotelle. The Works of Saint Augustine III/16. New York: New City Press.

2003 Expositions of the Psalms, 99-120, transl. Maria Boulding and ed. Boniface Chadwick, Henry Ramsey. The Works of Saint Augustine III/19. New York: New City Press.

$1991 \quad$ Confessions. Oxford: Oxford University Press.

Coxe, Arthur Cleveland 

Nicene and Post-Nicene Fathers VIII. New York 1887. Reprinted by Grand Rapids, MI: Eerdmans, 1996.

Dyson, R. W.

1998 The City of God against the Pagans. Cambridge: Cambridge University Press.

Gallagher, Donald A. and Idella J. Gallagher

1966 The Catholic and Manichaean Ways of Life (De moribus ecclesiae catholicae et de moribus Manichaeorum). The Fathers of the Church 56. Washington: The Catholic

Gavigan, John J. University of America Press.

1947 Christian Instruction (De doctrina Christiana). The Fathers of the Church 2. Washington: The Catholic University of America Press.

Haddan and Shedd

1887 On the Trinity (De Trinitate), transl. Rev. A. W. Haddan. Revised and annotated, with an Introductory Essay by William Shedd, ed. Philip Schaff. Nicene and PostNicene Fathers III. New York 1887. Reprint by Grand Rapids, MI: Eerdmans, 1998.

Hill, Edmund

1992 Sermons (94A-147A) III/4, transl. Edmund Hill and ed. John E. Rotelle. Hyde Park, New York: New City Press.

1997 Newly Discovered Sermons III/11, transl. Edmund Hill and ed. John E. Rotelle. Hyde Park, New York: New City Press.

2002 On Genesis, trans. Edmund Hill and ed. John E. Rotelle. Hyde Park, New York: New City Press.

2007 Essential sermons, transl. Edmund Hill and ed. Boniface Ramsey. Hyde Park, New York: New City Press.

Holmes, Peter

1887 The Anti-Pelagian Writings: De peccatorum meritis et remissione, De spiritu et littera, De natura et gratia, De perfectione iusticia hominis, De gestis Pelagii, De gratia Christi et peccato originali, De nuptiis et concupiscientia, De anima et eius origine, De gratia et libero arbitrio, transl. Peter Holmes, ed. Philip Schaff. Nicene and Post-Nicene Fathers V. New York 1887. Reprinted by Grand Rapids, MI: Eerdmans, 1997.

Jacobsson, Martin

2002 AURELIUS AUGUSTINUS.DE MUSICA VI: A Critical Edition with a Translation and an Introduction. Institutionen för klassiska språk, Stockholm.

King, Peter

1995 Against the academicians; The teacher. Indiana: Hackett.

King, Rev. J. R.

1887 The Anti-Donatist Writings: De baptismo, Contra litteras Petiliani, De correctione Donatistarum, transl. Rev. J. R. King. Revised and annotated by Rev. Chester D. Hartranft, ed. Philip Schaff. Nicene and Post-Nicene Fathers IV. New York 1887. Reprinted by Grand Rapids, MI: Eerdmans. 1996.

Levine, Philip

1966 Augustine: City of God, Vol. IV, Book 12-15. (Loeb Classical Library 414). Cambridge, MA: Harvard University Press.

McKenna, Stephen

1963 The Trinity. The Fathers of the Church 45. Washington: The Catholic University of America Press.

2002 On the Trinity (Books 8-15), transl. Stephen McKenna and ed. Gareth B. Matthews. Cambridge: Cambridge University Press.

McMahon, John J.

1947 The Magnitude of the Soul (De quantitate animae). The Fathers of the Church 4. Washington: The Catholic University of America Press.

Mourant, John A. and William J. Collinge

1992 On Nature and Grace (De natura et gratia). The Fathers of the Church 86. Washington: The Catholic University of America Press.

Parsons, Wilfrid

1951 Letters (1-82). The Fathers of the Church 12. Washington: The Catholic University of America Press.

1953 Letters (83-130). The Fathers of the Church 18. Washington: The Catholic University of America Press. 
Rettig, John W. University of America Press.

1995 Tractates on the First Epistle of John. The Fathers of the Church 92. Washington:

Russell, Robert P.

1948 Divine Providence and the Problem of Evil (De ordine). The Fathers of the Church 5. New York: CIMA, Inc.

1968 The Teacher, the Free Choice of the Will, Grace and Free Will. The Fathers of the Church 59. Washington: The Catholic University of America Press.

Sanford, E. M. and W. M. Green

1965 Augustine: City of God, Vol V, Books 16-18.35. (Loeb Classical Library 415).

Schopp, Ludwig Cambridge, MA: Harvard University Press.

1947 The Immortality of the Soul (De immortalitate animae) The Fathers of the Church 4. Washington: The Catholic University of America Press.

1948 The Happy Life (De beata uita). The Fathers of the Church 5. New York: CIMA.

Schumacher, Matthew A.

1957 Against Julian (Contra Julianum). The Fathers of the Church 35. Washington: The Catholic University of America Press.

Stothert, Rev. Richard

1887 The Anti-Manichaean Writings: Contra Faustum Manichaeum, transl. Rev. R. Stothert, ed. Philip Schaff. Nicene and Post-Nicene Fathers IV. New York 1887. Reprinted by Grand Rapids, MI: Eerdmans, 1996.

Taliaferro, Robert Catesby

1947 On Music (De musica) The Fathers of the Church 4. Washington: The Catholic Teske, Roland J. University of America Press.

1991 On Genesis against the Manichees (De Genesi contra Manichaeos); On the Literal Interpretation of Genesis: An Unfinished Book (De Genesi ad litteram imperfectus liber) The Fathers of the Church 84. Washington: The Catholic University of America Press.

Wallis, Rev. Robert Ernest

1887 The Anti-Pelagian Writings: Contra duas epistolas Pelagianorum, De correptione et gratia, De praedestinatione sanctorum, De dono perseuerantia, transl. Rev. R. E. Wallis, ed. Philip Schaff. Nicene and Post-Nicene Fathers V. New York 1887. Walsh, P. G. Reprinted by Grand Rapids, MI: Eerdmans, 1997.

2001 Augustine: De bono coniugali; De sancta uirginitate. Oxford: Clarendon Press.

Wiesen, David S.

1968 Augustine: City of God, Vol III, Books 8-11. (Loeb Classical Library 413). Cambridge, MA: Harvard University Press.

2. Other Authors

Cicero

King, J. E.

1927 Cicero: Tusculan Disputations. (Loeb Classical Library 141). Cambridge, MA: Harvard University Press.

Diogenes Laertius

Hicks, R. D.

1925 Diogenes Laertius: Lives of Eminent Philosophers II. (Loeb Classical Library 185).

Plotinus Cambridge, MA: Harvard University Press.

Armstrong, A. H.

1966 Plotinus (Porphyry on Plotinus): Ennead I. (Loeb Classical Library 440). Cambridge, MA: Harvard University Press.

Virgil

Fairclough, H. Rushton

1916 Virgil: Eclogues.Georgics-Aeneid I-VI. (Loeb Classical Library 63). Cambridge, MA: Harvard University Press. 


\section{Studies}

Ayres, Lewis

1999 "The Cappadocians", in Augustine through the Ages: An Encyclopedia (ed. Allan D. Fitzgerald). Michigan/Cambridge: Eerdmans. 121-124.

2014 "Augustine on the triune life of God", in The Cambridge Companion to Augustine (second edition) (ed. David Vincent Meconi and Eleonore Stump). Cambridge:

Baguette, Charles Cambridge University Press. 60-77.

1968 Le stö̈cisme dans la formation de saint Augustin. Université de Louvain: Ph.D. dissertation.

Baldwin, James Mark

1905 "Emotion", in Dictionary of Philosophy and Psychology (vol. 3) (ed. J.M. Baldwin). London: Macmillan. I, 316.

Bayer, Oswald

2006 "The Plurality of the one God and the Plurality of the Gods", in Pro Ecclesia 15:3, 338-354.

Bonner, Gerald

1986 “Augustine's Conception of Deification”, in Journal of Theological Studies 37, 369386.

2007 Freedom and Necessity: St. Augustine's Teaching on Divine Power and Human Freedom. Washington: The Catholic University of America Press.

Brachtendorf, Johannes

1997 "Cicero and Augustine on the Passions", in Revue des Études Augustiniennes 43, 289-308.

Brennan, Tad

1998 "The Old Stoic Theory of Emotions", in The Emotions in Hellenistic Philosophy (ed. J. Sihvola and T. Engberg-Pedersen). Dordrecht: Kluwer. 20-70.

Brown, Peter

1988 The Body and Society: Men, Women, and Sexual Renunciation in Early Christianity. New York: Columbia University Press.

2000 Augustine of Hippo: A Biography. Berkeley and Los Angeles: University of California Press. [1967]

Byers, Sarah Catherine

2003 "Augustine and the Cognitive Cause of Stoic 'Preliminary Passions (Propatheiai)",, in Journal of the History of Philosophy 41: 4, 433-448.

2013 Perception, Sensibility, and Moral Motivation in Augustine: A Stoic-Platonic Synthesis. Cambridge: Cambridge University Press.

Casiday, Augustine

2008 "Church Fathers and the Shaping of Orthodox theology", in The Cambridge Companion to Orthodox Christian Theology (ed. Mary B. Cunningham and Chadwick, Henry Elizabeth Theokritoff). Cambridge: Cambridge University Press. 167-187.

1966 Early Christian Thought and the Classical Tradition. Oxford: Clarendon Press.

1985 "The Ascetic Ideal in the History of the Church", in Monks, Hermits and the Ascetic Tradition (ed. W. J. Sheils). Oxford: Basil Blackwell, 1-24.

2009 Augustine of Hippo: A Life. New York: Oxford University Press.

Christensen, Michael

2007 "The Problem, Promise, and Process of Theosis", in Partakers of the Divine Nature: The History and Development of Deification in the Christian Traditions (ed. Michael J. Christensen and Jeffery A. Wittung). Grand Rapids, Michigan: Baker Academic. 23-31.

Clark, Mary T.

2001 "De Trinitate", in The Cambridge Companion to Augustine (ed. Eleonore Stump and Norman Kretzmann). Cambridge: Cambridge University Press. 91-102.

Colish, Marcia

1985 The Stoic Tradition from Antiquity to the Early Middle Ages (II). Leiden: Brill. Collins, Paul M.

2010 Partaking in Divine Nature: Deification and Communion. London: Bloomsbury T\&T Clark. 
Conley, Aaron D.

2015 "Augustine and Slavery: Freedom for the Free", in Augustine and Social Justice (ed. Teresa Delgado, John Doody and Kim Paffenroth). Lanham: Lexington Books. 131144.

Corcoran, Gervase

1985 Saint Augustine on Slavery. Roma: Institutum Patristicum “Augustinianum”.

Davidson, Ivor J.

2001 Ambrose: De officiis. New York: Oxford University Press.

Deane, Herbert A.

1963 The Political and Social Ideas of St. Augustine. New York and London: Columbia University Press.

Demacopoulos, George E. and Aristotle Papanikolaou

2008 "Augustine and the Orthodox: 'The West' in the East", in Orthodox Readings of Augustine (ed. George E. Demacopoulos and Aristotle Papanikolaou). Crestwood,

Dixon, Thomas New York: St. Vladimir Seminary Press. 11-40.

2003 From Passions to Emotions: The Creation of a Secular Psychological Category. Cambridge: Cambridge University Press.

2011 "Revolting Passions", in Modern Theology 27, 298-312.

2012 "Revolting Passions", in Faith, Rationality and the Passions (ed. Sarah Coakley). Wiley-Blackwell. 181-195.

Dodaro, Robert

2004 Christ and the Just Society in the Thought of Augustine. Cambridge University Press.

Edwards, Jonathan

1959 A Treatise Concerning Religious Affections. New Haven, CT: Yale University Press. Finch, Jeffrey D.

2007 "Neo-Palamism, Divinizing Grace, and the Breach between East and West", in Partakers of the Divine Nature: The History and Development of Deification in the Christian Traditions (ed., Michael J. Christensen and Jeffery A. Wittung). Grand Rapids, Michigan: Baker Academic. 233-249.

Fitzgerald, Allan

1999a "filioque", in Augustine through the Ages: An Encyclopedia (ed. Allan D. Fitzgerald). Michigan/Cambridge: Eerdmans. 369-370.

1999b "God's Mercy", in Augustine through the Ages: An Encyclopedia (ed. Allan D. Fitzgerald). Michigan/Cambridge: Eerdmans. 557.

Gavrilyuk, Paul L.

2004 The Suffering of the Impassible God: The Dialectics of Patristic Thought. New York: Oxford University Press.

Garnsey, Peter

1996 Ideas of Slavery from Aristotle to Augustine. Cambridge: Cambridge University Press.

Graver, Margaret

1999 "Philo of Alexandria and the Origins of the Stoic propatheiai", in Phronesis 44:4, $300-325$.

Gregory, Eric

2008 Politics and the Order of Love. Chicago: The University of Chicago Press.

Hagendahl, Harald

1967 Augustine and the Latin Classics. Göteborg: Acta Universitatis Gothoburgensis.

Harmless, William S.J.

1999 "Baptism", in Augustine through the Ages: An Encyclopedia (ed. Allan D. Harnack, Adolf Fitzgerald). Michigan/Cambridge: Eerdmans. 84-91.

1893 Outlines of the History of Dogma (transl. Edwin Knox Mitchell). London: Hodder and Stoughton.

1903 "Monarchianismus", in Realencyklopädie für protestantische Theologie und Kirche: Begründet von J. J. Herzog (ed. Albert Hauck). Leipzig: J. C. Hinrichs. 303-336.

Harrison, Carol

2000 Augustine: Christian Truth and Fractured Humanity. Oxford: Oxford University Press.

Heidl, György 
Holmes, Robert Piscataway, NJ: Gorgias Press.

1999 "St. Augustine and the Just War Theory", in The Augustinian Tradition (ed. Gareth Horn, Christoph Matthews). Berkeley and Los Angeles: University of California Press. 323-344.

1995 Augustinus. München: Beck.

Hughes, Kevin

2005 "Local Politics: The Political Place of the Household in Augustine's City of God", in Augustine and Politics (ed. John Doody, Kevin Hughes and Kim Paffenroth). Lanham, MD: Lexington Books. 145-164.

Hutcheson, Francis

2002 An Essay on the Nature and Conduct of the Passions and Affections, with Illustrations on the Moral Sense (Introduction by Aaron Garrett). Indianapolis: Liberty Fund.

Inwood, Brad

$1985 \quad$ Ethics and Human Action in Early Stoicism. Oxford: Clarendon Press.

1997 "Why do fools fall in love?", in Bulletin of the Institute of Classical Studies 41, 5569.

Irwin, Terence Henry

2003 "Augustine's Criticisms of the Stoic Theory of Passions", in Faith and Philosophy 20:4, 430-447.

2007 The Development of Ethics (Volume 1): From Socrates to the Reformation. Oxford: Järveläinen, Petri Oxford University Press.

$2000 \quad$ A Study on Religious Emotions. Helsinki: Luther-Agricola-Society.

Karfíková, Lenka

$2012 \quad$ Grace and the Will according to Augustine. Leiden·Boston: Brill.

Kärkkäinen, Veli-Matti

2004 One with God: Salvation as Deification and Justification. Collegeville, Minnesota:

Kaufman, John Liturgical Press.

2009 Becoming Divine, Becoming Human: Deification Themes in Irenaeus of Lyons. Keech, Dominic Oslo, MF Norwegian School of Theology: Ph.D. Dissertation.

2012 The Anti-Pelagian Christology of Augustine of Hippo, 396-430. Oxford: Oxford

Kelly, J.N.D University Press.

1977 Early Christian Doctrines (5th edition). London: A \& C Black.

Kenney, John Peter

2012 "Mystic and Monk: Augustine and the Spiritual Life", in A Companion to Augustine (ed. Mark Vessey). Malden: Wiley-Blackwell. 284-295.

Kharlamov, Vladimir

2012 "Basil of Caesarea and the Cappadocians on the Distinction between Essence and Energies in God and Its Relevance to the Deification Theme", in Theōsis: Deification in Christian Theology (Volume II) (ed. Vladimir Kharlamov). London: James Clarke. 100-145.

King, Peter

2010 "Emotions in Medieval Thought", in The Oxford Handbook of Philosophy of Emotion (ed. Peter Goldie). Oxford: Oxford University Press. 167-188.

2012a "Dispassionate Passions", in Emotion and Cognitive Life in Medieval and Early Modern Philosophy (ed. Martin Pickavé and Lisa Shapiro). Oxford University Press. 9-31.

2012b "Augustine and Anselm on Angelic Sin", in A Companion to Angels in Medieval Philosophy (ed. Tobias Hoffmann). Leiden: Brill. 261-282.

2012c “Augustine's Trinitarian Examples”, in Medioevo 37, 83-106.

King, Rev. J. R.

1887 "Introductory Essay" and "Preface", in Nicene \& Post-Nicene Fathers IV. New Kitamori, Kazoh

York. Reprinted by Grand Rapids, MI: Eerdmans, 1996. 372-406.

1965 Theology of the Pain of God. Louisville: John Knox Press. 
Knuuttila, Simo

2004 Emotions in Ancient and Medieval Philosophy. Oxford: Clarendon Press.

2012 "The Emotion of Shame in Medieval Philosophy", in Spazio Filosofico 5, 243-249.

2014 Sourcebook for the History of the Philosophy of Mind: Philosophical Psychology

Kolbet, Paul R. from Plato to Kant (ed. Simo Knuuttila and Juha Sihvola). Dordrecht: Springer.

$2010 \quad$ Augustine and the Cure of Souls: Revising a Classical Ideal. Notre Dame, Indiana: University of Notre Dame Press.

Lamberigts, Mathijs

2000 "A Critical Evaluation of Critiques of Augustine's View of Sexuality", in Augustine and his Critics (ed. Robert Dodaro and George Lawless). London and New York: Routledge.

Lancel, Serge

$2002 \quad$ Saint Augustine (transl. Antonia Nevill). London: SCM.

Lawless, George

1987 Augustine of Hippo and his Monastic Rule. Oxford: Clarendon Press.

2000 "Augustine's Decentring of Asceticism", in Augustine and his Critics (ed. Robert

Lenihan, David

Dodaro and George Lawless). London and New York: Routledge. 142-163.

1988 "Just war Theory in the Work of Saint Augustine", in Augustinian Studies 19, 3770 .

Lopes Pereira, Jairzinho

2013 Augustine of Hippo and Martin Luther on Original Sin and Justification of the Sinner. Göttingen: Vandenhoeck \& Ruprecht.

Lossky, Vladimir

1957 The Mystical Theology of the Eastern Church. London: James Clarke \& Co.

1977 "Elements of 'Negative Theology' in the Thought of St. Augustine", in St. Vladimir's Theological Quarterly 21. 67-75.

Lot-Borodine, Myrrha

1933 "La doctrine de la déification dans l'Église Grecque jusqu'au XI siècle", in Revue de l'histoire des religions. Paris: Librairie Ernest Leroux. 8-55.

1970 La déification de l'homme selon la doctrine des pères grecs. Paris: Editions du Cerf.

Louth, Andrew

2008 "The Patristic Revival and its Protagonists", in The Cambridge Companion to Orthodox Christian Theology (ed. Mary B. Cunningham and Elizabeth Theokritoff). Cambridge: Cambridge University Press. 188-202.

Markus, R. A.

1988 Saeculum: History and Society in the Theology of St. Augustine. Cambridge: Cambridge University Press. [1970].

1994 "De ciuitate dei: Pride and the Common Good", in Sacred and Secular: Studies on Augustine and Latin Christianity. Aldershot: Variorum. 245-254.

Marrocco, Mary N. R.

2000 Participation in the Divine Life in St. Augustine's De Trinitate and Selected Contemporary Homiletic Discourses. Toronto, University of St. Michael's College: Ph.D. Dissertation.

Marrou, Henri.

$1957 \quad$ Saint Augustine and his Influence through the Ages. New York: Harper Torchbooks. Matthews, Gareth B.

1992 Thought's Ego in Augustine and Descartes. New York: Cornell University Press. Mattox, John Mark

2006 Saint Augustine and the Theory of Just War. London·New York: Continuum.

McGrath, Alister E.

$2001 \quad$ Christian Theology: An Introduction (3rd edition). Oxford: Blackwell.

Meconi, David Vincent

2013 The One Christ: St. Augustine's theology of Deification. Washington: The Catholic University of America Press.

2014a “Augustine's Doctrine of Deification", in The Cambridge Companion to Augustine (second edition) (ed. David Vincent Meconi and Eleonore Stump). Cambridge: Cambridge University Press. 208-227.

2014b "Heaven and the ecclesia perfecta in Augustine", in The Cambridge Companion to Augustine (second edition) (ed. David Vincent Meconi and Eleonore Stump). 
Cambridge: Cambridge University Press. 251-272.

Moltmann, Jürgen

1974 The Crucified God: The Cross of Christ as the Foundation and Criticism of

Moreira, Isabel Christian Theology. London: SCM Press.

$2010 \quad$ Heaven's Purge: Purgatory in Late Antiquity. Oxford: Oxford University Press.

Nisula, Timo

2012 Augustine and the Functions of Concupiscence. Leiden-Boston: Brill.

Nnamani, A. G.

1995 The Paradox of a Suffering God: On the Classical, Modern Western and Third World Struggles to Harmonize the Incompatible Attributes of the Trinitarian God. Frankfurt am Main: Peter Lang.

Nussbaum, Martha

1994 The Therapy of Desire: Theory and Practice in Hellenistic Ethics. Princeton: Princeton University Press.

1998 "Eros and the Wise: The Stoic Response to a Cultural Dilemma", in The Emotions in Hellenistic Philosophy (ed. J. Sihvola and T. Engberg-Pedersen). Dordrecht: Kluwer, 272-304.

2001 Upheavals of Thought: The Intelligence of Emotions. Cambridge: Cambridge University Press.

O’Connell, Robert J.

1969 St. Augustine's Confessions: The Odyssey of Soul. Cambridge: Belknap Press.

O'Daly, Gerard

1987 Augustine's Philosophy of Mind. London: Duckworth.

1999 Augustine's City of God: A Reader's Guide. Oxford: Clarendon Press.

O’Daly, Gerard \& Zumkeller, Adolar

1986 "Affectus (passio, perturbatio)", in Augustinus-Lexikon (vol. 1) (ed. C. Mayer). Basel: Schwabe. 166-180.

O'Donovan, Oliver

2006 The Problem of Self-Love in St. Augustine. Eugene: Wipf and Stock Publishers.

Parrish, John M.

2005 "Two Cities and Two Loves: Imitation in Augustine's Moral Psychology and

Pelikan, Jaroslav Political Theology", in History of Political Thought 26, 209-235.

1971 The Emergence of the Catholic Tradition (100-600). Chicago and London: The University of Chicago Press.

1974 The Spirit of Eastern Christendom (600-1700). Chicago and London: The University of Chicago Press.

Rashdall, Hastings

1919 The Idea of Atonement in Christian Theology. London: Macmillan.

Rasmussen, Mette Sophia Bocher

2005 "Like a Rock or like God? The Concept of apatheia in the Monastic Theology of Evagrius of Pontus", in Studia Theologica 59, 147-162.

Riley-Smith, Jonathan

2008 The Crusades, Christianity, and Islam. New York: Columbia University Press.

Rist, John M.

$1994 \quad$ Augustine: Ancient Thought Baptized. Cambridge: Cambridge University Press.

Ruokanen, Miikka

1993 Theology of Social Life in Augustine's De civitate Dei. Göttingen: Vandenhoeck \& Ruprecht.

Russell, Norman

2004 The Doctrine of Deification in the Greek Patristic Tradition. Oxford: Oxford University Press.

Saarinen, Risto

2011 Weakness of Will in Renaissance and Reformation Thought. Oxford: Oxford University Press.

Sage, A.

1964 "Praeparatur voluntas a Deo", in Revue des études Augustiniennes 10, 1-20.

Saller, Richard P.

1994 Patriarchy, Property and Death in the Roman Family. Cambridge: Cambridge University Press. 

Household", in Classical Philology 94:2, 182-193.

Scrutton, Anastasia

2005 "Emotion in Augustine of Hippo and Thomas Aquinas: A Way Forward for the Im/passibility Debate?”, in International Journal of Systematic Theology 7, 169177.

Shaw, Brent D.

1987 "The Family in Late Antiquity: The Experience of Augustine", in Past \& Present 115.

Sherrard, Philip

1959 The Greek East and the Latin West: A Study in the Christian Tradition. London: Sorabji, Richard Oxford University Press.

$2000 \quad$ Emotion and Peace of Mind. New York: Oxford University Press.

2009 "Did the stoics value emotion and feeling?", in The Philosophical Quarterly 59, $150-162$.

Spanneut, Michel

1975 "Le stoïcisme et saint Augustin", in Forma Futuri: Studi in onore del Cardinale Michele Pellerino. Torino, Bottega d'Erasmo. 896-914.

Straw, Carole

1999 "Martyrdom", in Augustine through the Ages: An Encyclopedia (ed. Allan D. Fitzgerald). Michigan/Cambridge: Eerdmans. 538-542.

Stump, Eleonore

2001 "Augustine on free will", in The Cambridge Companion to Augustine (ed. Eleonore Stump and Norman Kretzmann). Cambridge: Cambridge University Press. 136-139.

Swift, Louis J.

1983 The Early Fathers on War and Military Service. Wilmington: Michael Glazier.

Theokritoff, Elizabeth

2008 "Creator and creation", in The Cambridge Companion to Orthodox Christian Theology (ed. Mary B. Cunningham and Elizabeth Theokritoff). Cambridge:

TeSelle, Eugene Cambridge University Press. 63-77.

1999 "Holy Spirit", in Augustine through the Ages: An Encyclopedia (ed. Allan D. Fitzgerald). Michigan/Cambridge: Eerdmans. 434-437.

Trigg, Joseph W.

1999 "Origen", in Augustine through the Ages: An Encyclopedia (ed. Allan D. Fitzgerald). Michigan/Cambridge: Eerdmans. 603-605.

Van Fleteren, Frederick

1999a "Demons", in Augustine through the Ages: An Encyclopedia (ed. Allan D. Fitzgerald). Grand Rapids, Michigan: William Eerdmans. 266-268.

1999b "Devil", in Augustine through the Ages: An Encyclopedia (ed. Allan D. Fitzgerald). Grand Rapids, Michigan: William Eerdmans. 268-269.

Van Oort, Johannes

1991 Jerusalem and Babylon: A Study into Augustine's City of God and the Sources of Vainio, Olli-Pekka His Doctrine of the Two Cities. Leiden: Brill.

$2008 \quad$ Justification and Participation in Christ. Leiden: Brill.

Van Riel, Gerd

2004 "MENS INMOTA MOTA MANE: Neoplatonic Tendencies in Augustine's Theory of Verbeke, Gérard the Passions", in Augustiniana 54, 507-531.

1958 "Augusin et le stoïcisme", in Recherches augustiniennes I, 67-89.

Wang, Tch'ang-Tche (王昌祉)

$1938 \quad$ Saint Augustin et les vertus des païens. Paris: Gabriel Beauchesne.

Weithman, Paul

2001 “Augustine's political philosophy”, in The Cambridge Companion to Augustine (ed. Eleonore Stump and Norman Kretzmann). Cambridge: Cambridge University Press. 234-252.

Wetzel, James

1992 Augustine and the Limits of Virtue. Cambridge: Cambridge University Press. White, Carolinne 
$\mathrm{Wu}$, Tianyue (吴天岳)

NY: Edwin Mellen Press.

2007a "Did Augustine Lost the Philosophical Battle in the Debate with Julian of Eclanum on Concupiscentia Carnis and Voluntas?", in Augustiniana 57, 7-30.

2007b "Shame in the Context of Sin: Augustine on the Feeling of Shame in De civitate Dei”, in Les Recherches de Théologie et Philosophie Médiévales 74, 1-31.

2009 "Augustine on Involuntary Sin: A Philosophical Defense”, in Augustiniana 59, 4578.

2010a "Rethinking Augustine's Adaptation of 'First Movements' of Affection", in The Modern Schoolman 87, 95-115.

$2010 \mathrm{~b}$ 《意愿与自由: 奥古斯丁意愿概念的道德心理学解读》, 北京: 北京大学出版 社。

Wu, Weiya (吳維亞)

1937 《聖奧古斯丁》（基督教學術推進會叢書：小傳集二），A. Shirley著 (Augustine, Saint Bishop of Hippo ），吳維亞譯述。上海：廣學會。

Xia, Dongqi (夏洞奇)

2007 《尘世的权威：奥古斯丁的社会政治思想》，上海：上海三联书店。

Yannaras, Christos

1975 "The Distinction between Essence and Energies and Its Importance for Theology", in St. Vladimir's Theological Quarterly 19, 232-245.

Zhang, Rong (张荣)

1999 《神圣的呼唤: 奥古斯丁宗教人类学研究》, 石家庄: 河北教育出版社。

Zhou, Weichi (周伟驰)

2001 《记忆与光照: 奥古斯丁神哲学研究》, 北京: 社会科学文献出版社。

2005 《奥古斯丁的基督教思想》, 北京: 中国社会科学出版社。

Zorgdrager, Heleen E.

2012 "A Practice of Love Myrrha Lot-Borodine (1882-1954) and the Modern Revival of the Doctrine of Deification", in Journal of Eastern Christian Studies 64, 287-307.

Zumkeller, Adolar

1986 Augustine's Ideal of the Religious Life. New York: Fordham University Press. 